Prepared in cooperation with the Mining and Minerals Division of the State of New Mexico Energy, Minerals and Natural Resources Department

\title{
Hydrologic Assessment and Numerical Simulation of Groundwater Flow, San Juan Mine, San Juan County, New Mexic0, 2010-13
}

\section{Scientific Investigations Report 2017-5155}

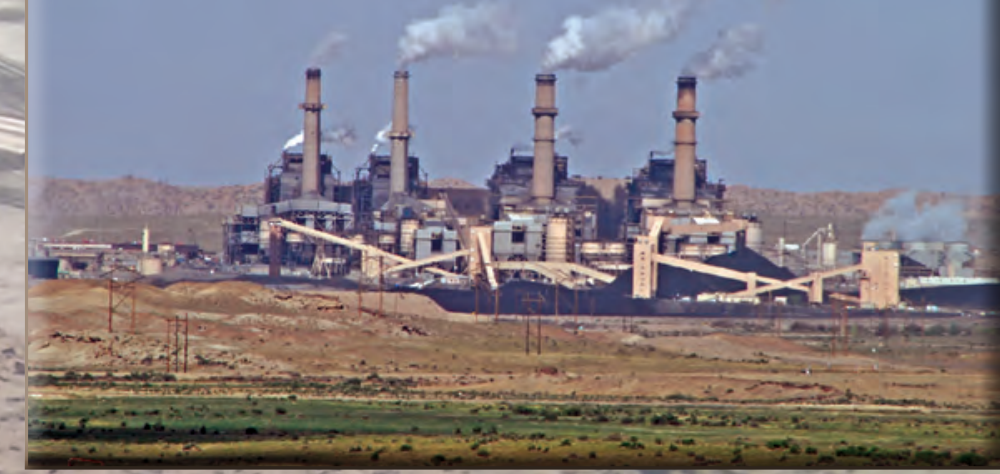

U.S. Department of the Interior

U.S. Geological Survey 


\section{Front cover:}

Background, San Juan Generating Station (SJGS) in background and ash disposal areas and access roads in foreground, February 8, 2012. Photograph by N. Myers (U.S. Geological Survey [USGS]).

Top right, SJGS from the east, May 6, 2014. Photograph by F. Gebhardt (USGS).

Bottom right, east of SJGS on underground mine lease area access road, showing San Juan Underground Mine signage, August 26, 2010.

Left, landscape northeast of SJGS, May 6, 2014. Photograph by F. Gebhardt (USGS).

\section{Back cover:}

Top right, coal combustion byproduct (CCB) repository north of SJGS, ash and spoil mounds in background and compacted CCB ash with mine spoil in foreground, August 25, 2010. The number 9 coal seam is visible along the terminal mine high wall in the background.

Middle right, CCB repository north of SJGS, with ash mounds in background and CCB ash covered with mine spoil in foreground, August 25, 2010.

Bottom right, CCB repositories north of SJGS, with ash mounds in background and CCB ash covered with mine spoil in foreground, August 25, 2010.

Top left, compacted CCB ash prior to covering with mine spoil at CCB repository north of SJGS, August 25, 2010.

Middle left, wellhead SJM-24-4. This well has since been destroyed by overdrilling in advance of underground mining. Photograph by F. Gebhardt (USGS).

Bottom left, landscape and incised ephemeral stream channel system viewed from the Hogback, west of SJGS.

\section{photo descriptions for page iv}

Top, San Juan Generating Station in background and water level monitoring at WellQNT by BHP Billiton, New Mexico Mining and Minerals Division, and USGS personnel, August 25, 2010.

Middle, Wellhead G3, August 25, 2010.

Bottom, Wellhead GA, July 14, 2014. Photograph by F. Gebhardt (USGS). 


\section{Hydrologic Assessment and Numerical Simulation of Groundwater Flow, San Juan Mine, San Juan County, New Mexico, 2010-13}

By Anne M. Stewart

Prepared in cooperation with the Mining and Minerals Division of the State of

New Mexico Energy, Minerals and Natural Resources Department

Scientific Investigations Report 2017-5155 


\title{
U.S. Department of the Interior \\ RYAN K. ZINKE, Secretary
}

\section{U.S. Geological Survey William H. Werkheiser, Deputy Director exercising the authority of the Director}

\author{
U.S. Geological Survey, Reston, Virginia: 2018
}

For more information on the USGS - the Federal source for science about the Earth, its natural and living resources, natural hazards, and the environment-visit https://www.usgs.gov or call 1-888-ASK-USGS.

For an overview of USGS information products, including maps, imagery, and publications, visit https://store.usgs.gov.

Any use of trade, firm, or product names is for descriptive purposes only and does not imply endorsement by the U.S. Government.

Although this information product, for the most part, is in the public domain, it also may contain copyrighted materials as noted in the text. Permission to reproduce copyrighted items must be secured from the copyright owner.

Suggested citation:

Stewart, A.M., 2018, Hydrologic assessment and numerical simulation of groundwater flow, San Juan Mine, San Juan County, New Mexico, 2010-13: U.S. Geological Survey Scientific Investigations Report 2017-5155, 94 p., https://doi.org/10.3133/sir20175155.

ISSN 2328-0328 (online) 


\section{Acknowledgments}

I am grateful to personnel of the New Mexico Mining and Minerals Division and the New Mexico Environment Department for their rapid responses to requests for information and for hosting my review of data archives in Santa Fe, New Mexico, in 2012. I thank Nadine Mead and the Mead Family Trust; R.G. Hunt; Michael Goen, Cynthia Hurtado, and Danny Kimball of the San Juan Generating Station; and Bill Skeet, Edward Epp, Steven Perkins, and Brent Musslewhite of the BHP Billiton San Juan Mine for permission to access and monitor groundwater wells on the San Juan Mine properties.

Special thanks to BHP Billiton personnel at San Juan Mine for their speedy responses to my information requests and for field support with unparalleled emphasis on safety. Thanks to all for the hospitality and shelter extended to our field personnel in the snowstorms, rainstorms, windstorms, and electrical storms of San Juan County, New Mexico.

Thanks to U.S. Geological Survey personnel Scott Christensen (retired) for assistance with surveys, Peter Bennett and David Lutz for field assistance, and to the USGS reviewers whose thoughtful contributions greatly improved this report. 

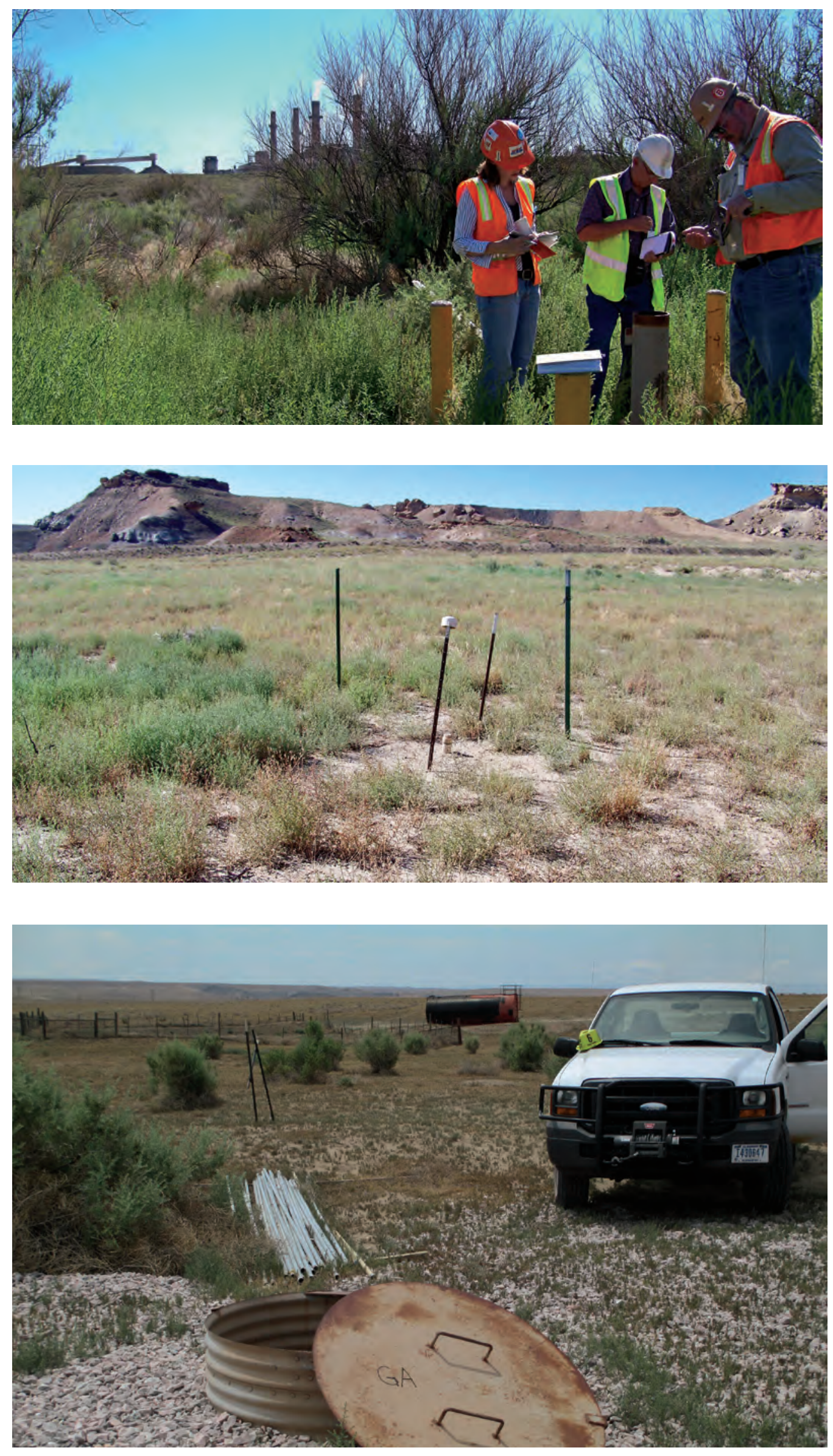


\section{Contents}

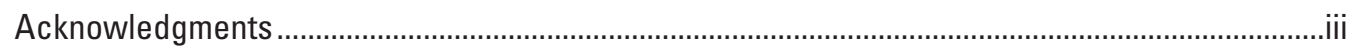

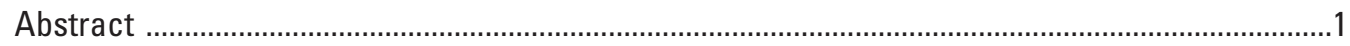

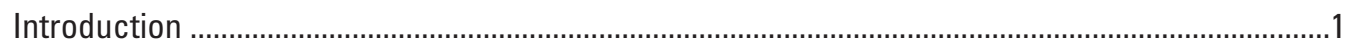

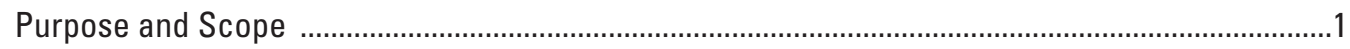

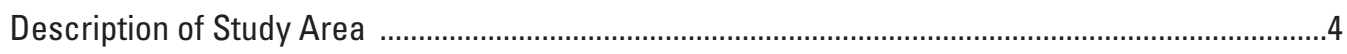

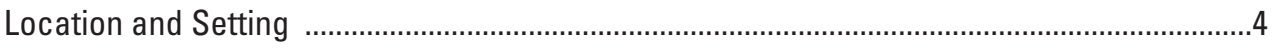

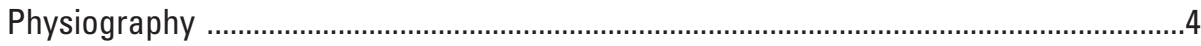

Regional Climate ...................................................................................................

Local Temperature, Precipitation, and Evaporation .........................................................4

Land Uses in the Study Area .......................................................................................

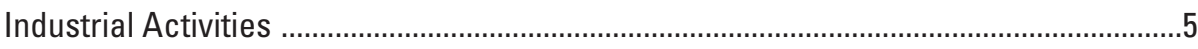

San Juan Generating Station .............................................................................

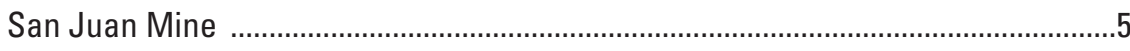

Other Coal Mining Activities .............................................................................10

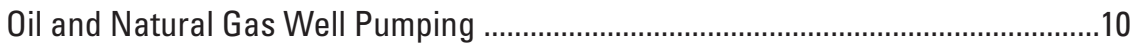

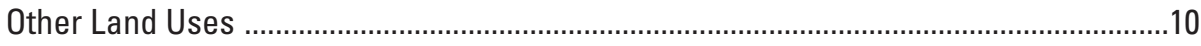

Previous Descriptions of the Hydrogeologic Setting …….................................................. 10

Geologic History and Structure ...................................................................................11

Hydrologic Assessment of the San Juan Mine Study Area .......................................................11

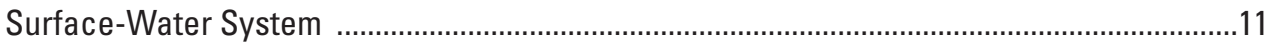

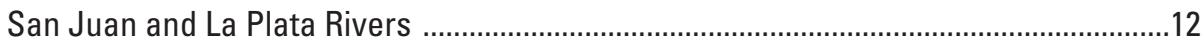

Westwater and Shumway Arroyos ..............................................................................12

Natural Ponds, Lakes, Seeps, and Springs ..............................................................13

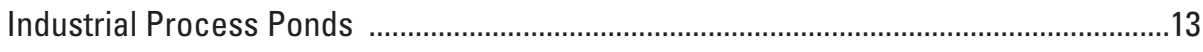

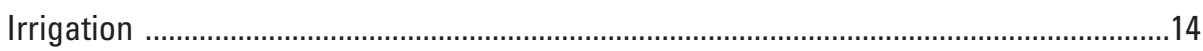

Hydrostratigraphic Structure and Setting of the Central San Juan Basin and the

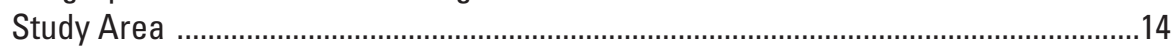

Hydrostratigraphic Framework of the Study Area ....................................................15

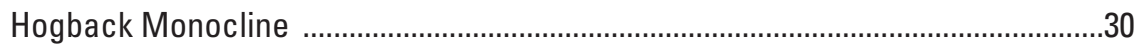

Cretaceous Cliff House Sandstone ....................................................................30

Cretaceous Lewis Shale ................................................................................3

Cretaceous Pictured Cliffs Sandstone ...............................................................

Cretaceous Fruitland Formation and Kirtland Shale .............................................31

Cretaceous-Tertiary Animas Formation and 0jo Alamo Sandstone and Tertiary Nacimiento Formation ..................................................................32

Quaternary Eolian Dune-Sand Deposits and Alluvium ..........................................33

Recent Mine Spoil, Coal Combustion Byproducts (Ash), and Subsided

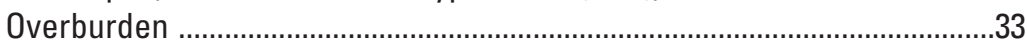

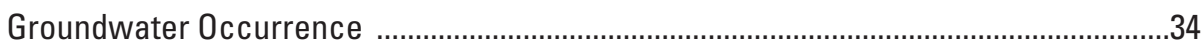

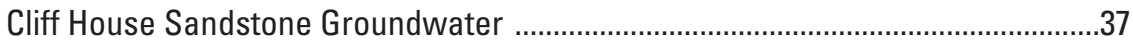

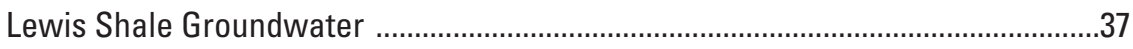

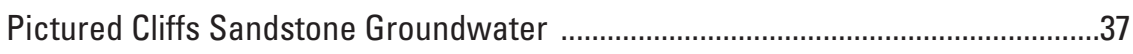

Number 8 Coal and Kirtland-Fruitland (Undifferentiated) Groundwater ................40 


\section{Figures}

1. Maps showing study area in the San Juan Basin and location of the San Juan Generating Station, San Juan Mine, monitoring wells, coal combustion byproduct repository, and other topographic and hydrologic features; and locations of surface-water gages, municipalities, Tribal lands, and other topographic and hydrologic features, San Juan County, New Mexico

2. Map showing surface geology and cross sections showing stratigraphy, San Juan Mine and vicinity, San Juan County, New Mexico

3. Hydrograph showing hydraulic-head relations at long-term period of record Kpc wells, San Juan County, New Mexico 
4. Hydrograph showing hydraulic-head relations at long-term period of record Kkf and Kpc wells, San Juan County, New Mexico

5. Hydrograph showing hydraulic-head relations at wells KPC1, QAL3, and MW4, San Juan County, New Mexico

6. Hydrograph showing hydraulic-head relations at Shumway Arroyo backwater reach Kpc wells, San Juan County, New Mexico

7. Hydrograph showing hydraulic-head relations at wells KPC3 and SM7, San Juan County, New Mexico

8. Hydrograph showing hydraulic-head relations at wells G3 and G26, San Juan County, New Mexico

9. Hydrograph showing hydraulic-head relations at wells GC, SA1/KF2, and KF2/KF2D, San Juan County, New Mexico

10. Hydrograph showing hydraulic-head relations at wells SA1/KF2, KF2/KF2D, and SM5, San Juan County, New Mexico

11. Hydrograph showing hydraulic-head relations at representative shallow alluvial system wells at San Juan Mine and San Juan Generating Station, San Juan County, New Mexico

12. Potentiometric-surface contours of the San Juan Mine shallow alluvial system, February 2013, San Juan County, New Mexico

13. Hydrograph showing hydraulic-head relations at Shumway Arroyo backwater reach wells, San Juan County, New Mexico

14. Hydrograph showing hydraulic-head relations at wells QNT and SM6, San Juan County, New Mexico

15. Hydrograph showing hydraulic-head relations at wells QNT and SM7, San Juan County, New Mexico

16. Hydrograph showing hydraulic-head relations at wells SM6 and SM7, San Juan County, New Mexico

17. Graphs showing groundwater chemical constituents at wells $Q A L 3, M W 4$, and KPC1; wells GE, GL, KPC2, KPC4, and KPC5; and wells NEP3, NEP4, ONT, and GD ........37

18. Maps showing model layers in relation to surficial geology in the vicinity of the San Juan Mine, San Juan County, New Mexico

19. Map showing Layer 1 calibration targets and residuals, boundary conditions, calibrated horizontal hydraulic conductivity distribution, inactive Layer 1 grid cells, and model grid row and column numbers

20. Map showing Layer 2, calibration target and residual, calibrated hydraulic conductivity distribution and calibrated steady-state potentiometric contours, Kernodle's (1996) Cretaceous Kirtland Shale/Fruitland Formation potentiometric results, and locations of coal combustion byproduct ash repositories

21. Map showing Layer 3, calibration targets and residuals, post-mining hydraulic conductivity distribution, calibrated steady-state potentiometric contours, and locations of coal combustion byproduct ash repositories

22. Map showing Layer 4, calibration targets and residuals, calibrated hydraulic conductivity distribution, and calibrated potentiometric contours with Kernodle's (1996) Kpc potentiometric results

23. Map showing Layer 5, calibrated hydraulic conductivity distribution, and calibrated potentiometric contours

24. Map showing Layer 6, calibrated general head boundary cells, hydraulic conductivity distribution, and potentiometric contours with Kernodle's (1996) Kch model results 
25. Map showing calibrated groundwater recharge zones and values .............................58

26. Map showing calibrated evapotranspiration zones and values ....................................59

27. Map showing Layer 3 transient drain and extraction-well boundary conditions related to dewatering for mining and oil and gas production ........................................60

28. Cross section of the groundwater recovery numerical model grid along Row 54 showing cells representing reclamation areas, the underground-mine subsidence zone, and equipotential lines at the end of the groundwater recovery simulation 61

29. Graph showing residual, simulated, and observed heads at 14 steady-state calibration targets, San Juan Mine numerical groundwater model

30. Graph showing global model input sensitivities tested using multiplicative factors of $0.25,0.50,2$, and 4

31. Graphs showing modeled groundwater recovery timing at north, central, and south coal combustion byproduct storage areas for Layer 3 with location map showing initial particle positions, subsidence zone at underground mine, and potentiometric surface for Layer 3 at the start of the first stress period (day 1) of the groundwater-recovery model

32. Maps showing modeled particle tracks and arrival times after cessation of dewatering. Case 1 applied largest reported hydraulic conductivity and porosity values for CCB respository fill; Case 2 applied reduced values for both parameters

\section{Tables}

1. Locations, water-bearing units of completion, and completion details of monitoring wells at or in the vicinity of the San Juan Mine, San Juan County, New Mexico

2. Mean annual gaged streamflow for U.S. Geological Survey streamgages in the vicinity of the San Juan Mine, San Juan County, New Mexico

3. Hydraulic properties of water-bearing units in the vicinity of the San Juan Mine, San Juan County, New Mexico

4. Average concentrations of calcium, chloride, sodium, sulfate and dissolved solids for given date ranges for groundwater at or in the vicinity of the San Juan Mine, New Mexico

5. San Juan Mine study area conceptual model: preliminary quantifications and conceptualizations for numerical modeling, San Juan, New Mexico

6A. Parameters and calibrated values used in the San Juan Mine groundwater model

6B. Recharge and discharge stresses tested, calibrated values, and flux estimates developed for the San Juan Mine groundwater model

7. Volumetric daily water balance results from calibrated steady-state model and layers, San Juan Mine groundwater model, showing correspondence to initial estimates from conceptual model 


\section{Conversion Factors}

International System of Units to U.S. customary units

\begin{tabular}{|c|c|c|}
\hline Multiply & By & To obtain \\
\hline \multicolumn{3}{|c|}{ Length } \\
\hline centimeter $(\mathrm{cm})$ & 0.3937 & inch (in.) \\
\hline meter (m) & 3.281 & foot $(\mathrm{ft})$ \\
\hline kilometer (km) & 0.6214 & mile (mi) \\
\hline \multicolumn{3}{|c|}{ Area } \\
\hline square meter $\left(\mathrm{m}^{2}\right)$ & 0.0002471 & acre \\
\hline square kilometer $\left(\mathrm{km}^{2}\right)$ & 247.1 & acre \\
\hline square meter $\left(\mathrm{m}^{2}\right)$ & 10.76 & square foot $\left(\mathrm{ft}^{2}\right)$ \\
\hline square kilometer $\left(\mathrm{km}^{2}\right)$ & 0.3861 & square mile $\left(\mathrm{mi}^{2}\right)$ \\
\hline \multicolumn{3}{|c|}{ Volume } \\
\hline cubic meter $\left(\mathrm{m}^{3}\right)$ & 35.31 & cubic foot $\left(\mathrm{ft}^{3}\right)$ \\
\hline cubic meter $\left(\mathrm{m}^{3}\right)$ & 0.0008107 & acre-foot (acre-ft) \\
\hline \multicolumn{3}{|c|}{ Flow rate } \\
\hline cubic meter per year (m³/yr) & 0.000811 & acre-foot per year (acre-ft/yr) \\
\hline meter per day (m/d) & 3.281 & foot per day (ft/d) \\
\hline meter per year (m/yr) & 3.281 & foot per year ft/yr) \\
\hline cubic meter per day (m³/d) & 35.31 & cubic foot per day (ftº/d) \\
\hline \multicolumn{3}{|c|}{ Hydraulic conductivity } \\
\hline meter per day (m/d) & 3.281 & foot per day (ft/d) \\
\hline \multicolumn{3}{|c|}{ Transmissivity* } \\
\hline meter squared per day (m²/d) & 10.76 & foot squared per day $\left(\mathrm{ft}^{2} / \mathrm{d}\right)$ \\
\hline
\end{tabular}

Temperature in degrees Celsius $\left({ }^{\circ} \mathrm{C}\right)$ may be converted to degrees Fahrenheit $\left({ }^{\circ} \mathrm{F}\right)$ as ${ }^{\circ} \mathrm{F}=(1.8 \times$ $\left.{ }^{\circ} \mathrm{C}\right)+32$.

Temperature in degrees Fahrenheit $\left({ }^{\circ} \mathrm{F}\right)$ may be converted to degrees Celsius $\left({ }^{\circ} \mathrm{C}\right)$ as ${ }^{\circ} \mathrm{C}=\left({ }^{\circ} \mathrm{F}-\right.$ 32) / 1.8 .

Darcy, a measure of permeability in centimeter-gram-second units; incorporates fluid properties including dynamic viscosity, temperature, and air-pressure; one darcy (D) is equivalent to a hydraulic conductivity value of $0.831 \mathrm{~m} / \mathrm{d}(2.73 \mathrm{ft} / \mathrm{d})$.

In the text of this report conversions between international (metric) system units and inch/pound (English) system units are approximate because the converted values have been rounded.

\section{Datums}

Vertical coordinate information is referenced to the North American Vertical Datum of 1988 (NAVD 88).

Horizontal coordinate information is referenced to the North American Datum of 1983 (NAD 83).

Elevation, as used in this report, refers to distance above the vertical datum. 


\section{Supplemental Information}

Transmissivity: The standard unit for transmissivity is cubic meter per day per square meter times meter of aquifer thickness $\left[\left(\mathrm{m}^{3} / \mathrm{d}\right) / \mathrm{m}^{2}\right] \mathrm{m}$. In this report, the mathematically reduced form, meter squared per day $\left(\mathrm{m}^{2} / \mathrm{d}\right)$, is used for convenience.

Hydraulic conductivity: Intrinsic permeability of the porous media $\left(\mathrm{m}^{2}\right)$ times fluid density $\left(\mathrm{mass} / \mathrm{m}^{3}\right)$ times gravitational acceleration $\left(\mathrm{m} / \mathrm{d}^{2}\right)$ divided by the dynamic viscosity of the fluid (Force $\mathrm{d} / \mathrm{m}^{2}$ ) or $\left(\mathrm{mass} \mathrm{m} / \mathrm{d}^{2} \times \mathrm{d} / \mathrm{m}^{2}\right.$ ) (Freeze and Cherry, 1979). In this report, the mathematically reduced form, meter per day, is used for convenience. Hydraulic conductivity can be represented and calculated as the transmissivity per meter of saturated aquifer thickness.

Concentrations of chemical constituents in water are given in either milligrams per liter (mg/L) or micrograms per liter ( $\mu \mathrm{g} / \mathrm{L})$.

\section{Abbreviations}

$\begin{array}{ll}\text { BDM } & \text { Black Diamond Mine } \\ \text { CCB } & \text { coal combustion byproduct } \\ \text { D } & \text { a measure of permeability, see explanation in Conversion Factors section } \\ \text { DEM } & \text { digital elevation model } \\ \text { GHB } & \text { general head boundary } \\ \text { GIS } & \text { geographic information system } \\ \text { GWV } & \text { Groundwater Vistas } \\ \text { HC } & \text { hydraulic conductivity } \\ \text { Kch } & \text { Cretaceous Cliff House Sandstone } \\ \text { Kf } & \text { Cretaceous Fruitland Formation } \\ \text { Kfn8 } & \text { Cretaceous Number 8 coal seam of the Fruitland Formation } \\ \text { Kkf } & \text { Cretaceous Kirtland Shale/Fruitland Formation (undifferentiated) } \\ \text { Kks } & \text { Cretaceous Kirtland Shale } \\ \text { Kls } & \text { Cretaceous Lewis Shale } \\ \text { Kpc } & \text { Cretaceous Pictured Cliffs Sandstone } \\ \text { LPM } & \text { La Plata Mine } \\ \text { mD } & \text { one-thousandth of a Darcy (D, see abbreviation and explanation in Conversion } \\ \text { MMD } & \text { Factors section) } \\ \text { MEP } & \text { Mining and Minerals Division of the New Mexico Energy, Minerals and Natural } \\ \text { NMEMNRD } & \text { Nesources Department } \\ \text { NMOSE } & \text { New Mexico Energy, Minerals and Natural Resources Department } \\ \text { NWIS } & \text { National Water Information System } \\ & \end{array}$




\begin{tabular}{|c|c|}
\hline OFV & objective function value \\
\hline PEST & parameter estimation method \\
\hline Qal & Quaternary alluvium \\
\hline Qnt & Quaternary Naha and Tsegi eolian deposits, undifferentiated \\
\hline RASA & regional aquifer-system analysis \\
\hline RTW & recovery trench well \\
\hline S & $\begin{array}{l}\text { Storativity, water volume released from or added to storage of a confined aquifer } \\
\text { per unit surface area per unit decline of hydraulic head over saturated aquifer } \\
\text { thickness }\end{array}$ \\
\hline SA & Shumway Arroyo \\
\hline SABR & Shumway Arroyo backwater reach \\
\hline SFR & streamflow routing \\
\hline SJGS & San Juan Generating Station \\
\hline SJM & San Juan Mine, San Juan Coal Mine \\
\hline SM & spoil monitoring well \\
\hline Ss & $\begin{array}{l}\text { Specific storage of a confined aquifer where } S \text { is divided by aquifer saturated } \\
\text { thickness }\end{array}$ \\
\hline Sy & $\begin{array}{l}\text { Specific yield, water volume released from or added to storage of an unconfined } \\
\text { aquifer, as a percentage }\end{array}$ \\
\hline TKa & Tertiary-Cretaceous Animas Formation \\
\hline TKoa & Tertiary-Cretaceous 0jo Alamo Formation \\
\hline USGS & U.S. Geological Survey \\
\hline WRRS & Water Rights Reporting System \\
\hline WWA & Westwater Arroyo \\
\hline
\end{tabular}





\title{
Hydrologic Assessment and Numerical Simulation of Groundwater Flow, San Juan Mine, San Juan County, New Mexico, 2010-13
}

\author{
By Anne M. Stewart ${ }^{1}$
}

\begin{abstract}
Coal combustion byproducts (CCBs), which are composed of fly ash, bottom ash, and flue gas desulfurization material, produced at the coal-fired San Juan Generating Station (SJGS), located in San Juan County, New Mexico, have been buried in former surface-mine pits at the San Juan Mine, also referred to as the San Juan Coal Mine, since operations began in the early 1970s. This report, prepared by the U.S. Geological Survey in cooperation with the Mining and Minerals Division of the New Mexico Energy, Minerals and Natural Resources Department, describes results of a hydrogeologic assessment, including numerical groundwater modeling, to identify the timing of groundwater recovery and potential pathways for groundwater transport of metals that may be leached from
\end{abstract} stored CCBs and reach hydrologic receptors after operations cease. Data collected for the hydrologic assessment indicate that groundwater in at least one centrally located reclaimed surface-mining pit has already begun to recover.

The U.S. Geological Survey numerical modeling package MODFLOW-NWT was used with MODPATH particle-tracking software to identify advective flow paths from CCB storage areas toward potential hydrologic receptors. Results indicate that groundwater at CCB storage areas will recover to the former steady state, or in some locations, groundwater may recover to a new steady state in 6,600 to 10,600 years at variable rates depending on the proximity to a residual cone-of-groundwater depression caused by mine dewatering and regional oil and gas pumping as well as on actual, rather than estimated, groundwater recharge and evapotranspirational losses. Advective particle-track modeling indicates that the number of particles and rates of advective transport will vary depending on hydraulic properties of the mine spoil, particularly hydraulic conductivity and porosity. Modeling results from the most conservative scenario indicate that particles can migrate from CCB repositories to either the Shumway Arroyo alluvium after 1,320 years and from there to the San Juan River alluvium after 1,520 years or from southernmost CCB repositories directly to the San Juan River alluvium after 2,400 years after the cessation of mining.

${ }^{1}$ Retired.

\section{Introduction}

Coal combustion byproducts (CCBs), which are composed of fly ash, bottom ash, and flue gas desulfurization material, are produced by operation of the coal-fired San Juan Generating Station (SJGS), located in San Juan County, New Mexico. CCBs have been buried nearby in former surfacemine pits at the San Juan Mine (SJM), also referred to as the San Juan Coal Mine, since the SJGS power plant began operation in the early 1970s (Mining and Minerals Division [MMD], 2017a). Disposal of CCBs is overseen by the MMD of the State of New Mexico Energy, Minerals and Natural Resources Department (NMEMNRD).

Regional dewatering for oil and gas production has been ongoing in the area since the 1960s (GO-TECH, 2014, 2016). Local dewatering for surface and underground mining has been ongoing since the early 1970s. It is anticipated that power generation, and hence, local dewatering will cease at some time in the future. (For this project, it was assumed that regional oil and gas dewatering will cease at the same time). Upon cessation of dewatering activities, it is expected that groundwater in dewatered areas will recover, potentially allowing groundwater to transport metals associated with CCBs from repositories to hydrologic receptors along unknown pathways.

To address these concerns, the U.S. Geological Survey (USGS), in cooperation with the MMD of the NMEMNRD, prepared a hydrogeologic assessment at and in the vicinity of the SJM, including numerical groundwater modeling, focused on identifying the timing of groundwater recovery and potential pathways for groundwater transport of metals that may be leached from CCBs after the cessation of mining at the SJM.

\section{Purpose and Scope}

The purpose of this report is to present results of a hydrologic assessment and associated numerical simulation of groundwater flow in the vicinity of the SJM. The study area is located in San Juan County, N. Mex., and La Plata County, Colorado, in the central San Juan Basin (fig. 1A). 


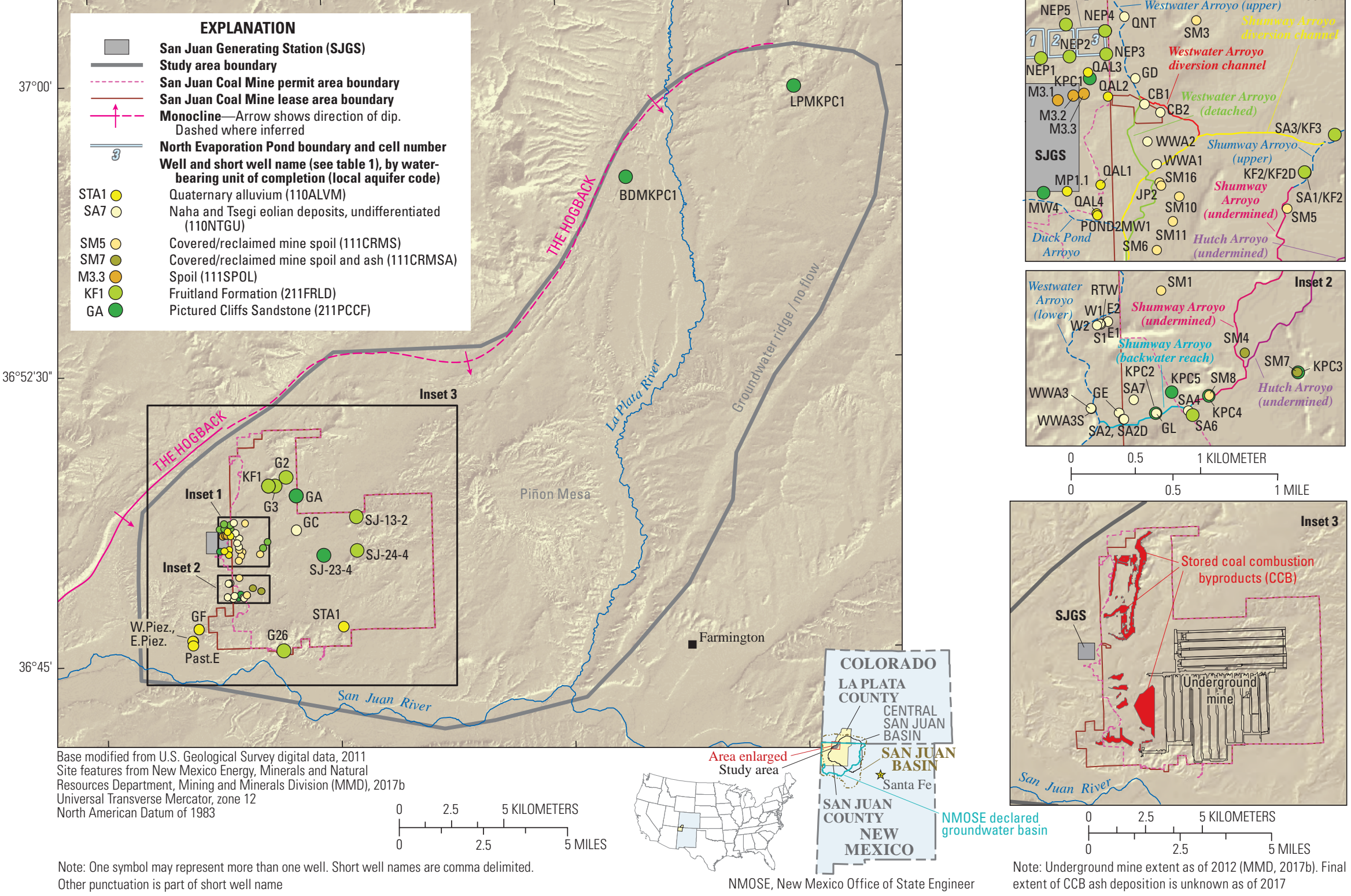

Figure 1. A, Study area in the San Juan Basin and location of the San Juan Generating Station, San Juan Mine, monitoring wells, coal combustion byproduct (CCB) repository, and other topographic and hydrologic features; and $B$, locations of surface-water gages, municipalities, Tribal lands, and other topographic and hydrologic features, San Juan County, New Mexico. 


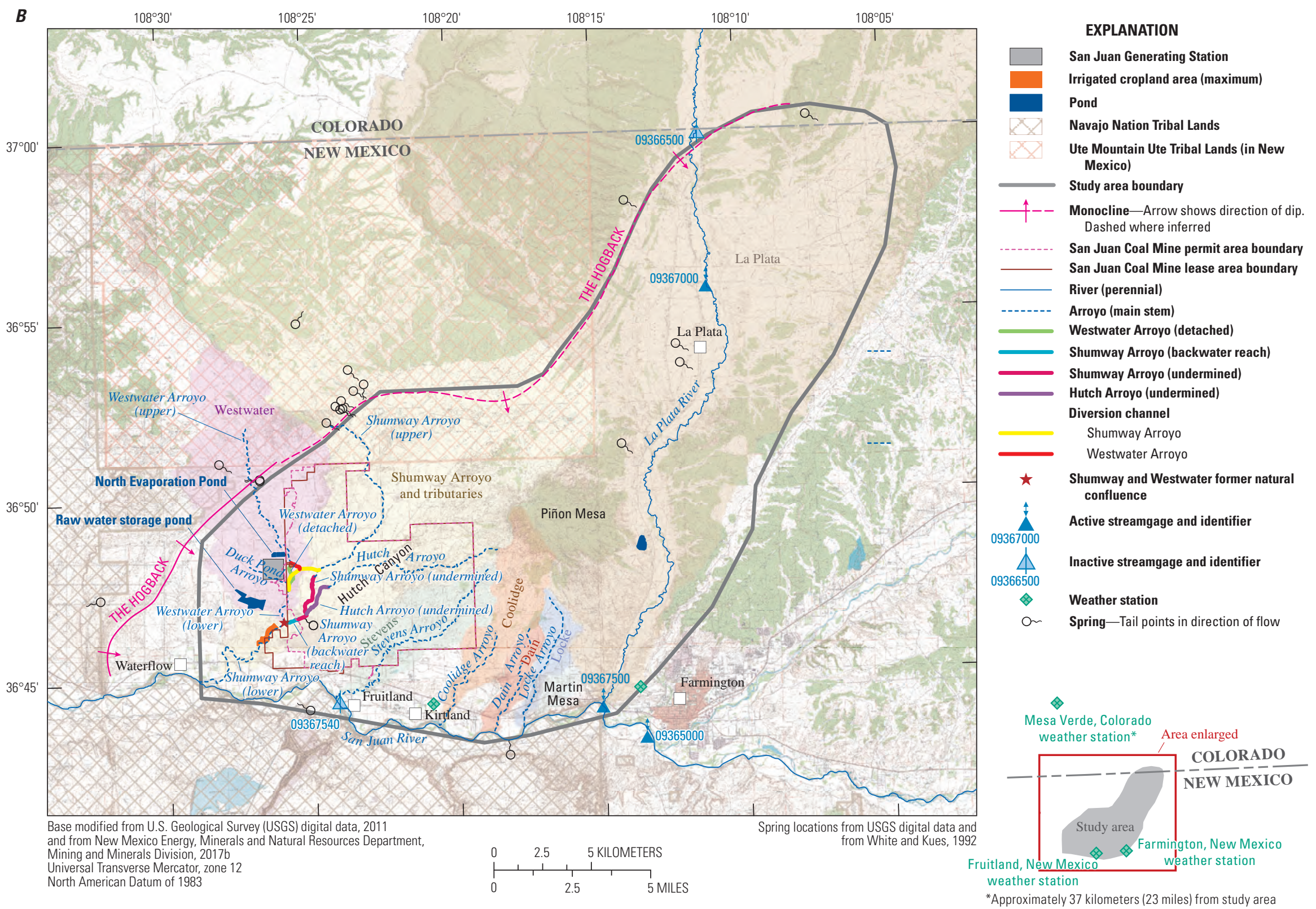

Figure 1. Maps showing $A$, study area in the San Juan Basin and location of the San Juan Generating Station, San Juan Mine, monitoring wells, coal combustion byproduct (CCB) repository, and other topographic and hydrologic features; and $B$, locations of surface-water gages, municipalities, Tribal lands, and other topographic and hydrologic features, San Juan County, New Mexico.-Continued 
Hydrologic Assessment and Numerical Simulation of Groundwater Flow, San Juan Mine, San Juan County, N. Mex.

The report describes site-specific hydrologic information that was developed to determine, using numerical modeling, potential pathways and arrival times of groundwater flow from CCB storage pits at the SJM that could allow metals that can be leached from CCBs to reach hydrologic receptors, such as wells or streams. The assessment was performed between 2010 and 2013 and included a review of existing literature, the collection of groundwater-level and other sitespecific data, and synthesis of the collected data. Reviewed literature included consultant and regulatory reports specific to hydrologic conditions at the SJM and the SJGS, various SJM and SJGS permits and historical records, and reports produced by various governmental agencies and consultants describing regional hydrologic conditions. A companion USGS data series report (Stewart and Thomas, 2015) documents depth-togroundwater data and groundwater-chemistry data.

The collected hydrologic information was used in numerical groundwater-flow modeling to estimate quantitatively the time required for the groundwater system to return to a steady state after cessation of mining and other industrial land uses. Advective-flow modeling (particle tracking) was used to identify groundwater-flow paths and associated traveltimes from CCB storage pits to hydrologic receptors.

\section{Description of Study Area}

\section{Location and Setting}

The study area abuts the western boundary of the central San Juan Basin in San Juan County, N. Mex., and extends 1.2 kilometers $(\mathrm{km})(3 / 4$ mile [mi]) into La Plata County, Colo. (fig. 1A). The study area spans 35 km (22 mi) from east to west and $32 \mathrm{~km}(20 \mathrm{mi})$ from north to south, representing a nonrectangular area of 606 square kilometers $\left(\mathrm{km}^{2}\right)$ (234 square miles $\left.\left[\mathrm{mi}^{2}\right]\right)$. In the study area, land-surface elevations range from 1,975 meters $(\mathrm{m})(6,480$ feet [ft]) to $1,536 \mathrm{~m}(5,040 \mathrm{ft})$, representing a total relief of $440 \mathrm{~m}$ $(1,440 \mathrm{ft})$ across the study area. Land-surface elevations are greatest in highland areas along the northern and eastern study area boundaries, along the Hogback monocline, and at Piñon Mesa in the central part of the study area (fig. 1B). The lowest land-surface elevation is at the San Juan River outflow in the southwestern corner of the study area (fig. 1A).

Hydrologic features were used to bound the study area. The Hogback monocline (described in a following section) was selected as the western boundary. Highland areas contiguous with the Hogback monocline (inferred as the outcrop of the upper surface of the Lewis Shale of Cretaceous age, described in a following section) and the La Plata River Valley (Kelly, 1957; Craigg, 2001) were selected as the northwestern and northern boundaries. A groundwater divide traced along a groundwater ridge located east of La Plata
River, following Kernodle's (1996) modeling results, was selected as the eastern boundary. The San Juan River alluvial groundwater system was selected as the southern boundary.

\section{Physiography}

The San Juan Basin (fig. 1A) is characterized by highland areas (mesas, cuestas, or buttes) that are separated by lowland areas (valleys, badlands, or canyons) (Roybal and others, 1983). Vegetation types vary with elevation and associated orographic precipitation regimes. In the vicinity of the SJM, vegetation is dominated by desert grasslands at elevations below 1,675 $\mathrm{m}(5,500 \mathrm{ft})$ and by piñon-juniper woodlands at higher elevations (Roybal and others, 1983).

The study area contains the southeastern part of the Ute Mountain Ute Tribal lands and borders the northern and eastern boundaries of the Navajo Nation (fig. 1B). The city of Farmington, N. Mex., with a population of about 46,000 , is adjacent to the southeastern corner of the study area, just east of the confluence of the San Juan and La Plata Rivers (figs. $1 A$ and $1 B$ ). Several unincorporated communities including Kirtland, Fruitland, and Waterflow, N. Mex. (fig. 1B) with populations of about 8,000 (population data are combined for Kirtland and Fruitland) and 1,700, respectively, are located along the San Juan River at the southern study area boundary. The unincorporated community of La Plata, N. Mex., with a population of about 600, is located along the La Plata River (U.S. Census Bureau, 2010; fig. 1B).

\section{Regional Climate}

The study area climate is arid to semiarid (Roybal and others, 1983; Stone and others, 1983; Thomson and others, 2012). Abnormally dry to exceptional drought conditions generally were observed in 20 percent or more of San Juan County from 2000 to 2014 (New Mexico Climate Center, 2014).

\section{Local Temperature, Precipitation, and Evaporation}

The following discussion of study area weather stations includes stations located at Fruitland and Farmington, N. Mex. The weather station at Mesa Verde, Colo. was included to represent temperatures and precipitation rates related to high elevations that are otherwise not well-represented by weather stations in the study area. This weather station is located $37 \mathrm{~km}(23 \mathrm{mi})$ northwest of the study area boundary within the San Juan Basin, but outside of the central basin (fig. 1B).

The 30-year (1981-2010) average (normal) annual temperatures at Fruitland and Farmington, N. Mex., and Mesa Verde, Colo. (fig. 1B), are 10.6, 11.6, and 9.6 degrees Celsius $\left({ }^{\circ} \mathrm{C}\right)$, respectively (51.0, 52.8 and 49.2 degrees Fahrenheit $\left[{ }^{\circ} \mathrm{F}\right]$; climate data from Arguez and others, 2010). The normal 
minimum temperatures are $1.2,3.3$, and $2.9^{\circ} \mathrm{C}$ (34.2, 38.0, and $37.3^{\circ} \mathrm{F}$ ), and the normal maximum temperatures are 19.9, 19.7, and $16.2^{\circ} \mathrm{C}\left(67.9,67.5\right.$, and $\left.61.1^{\circ} \mathrm{F}\right)$, respectively, for each of the three stations. Normal annual precipitations are $21.0,28.0$, and 47.0 centimeters $(\mathrm{cm})(8.28,11.03$, and 18.5 inches [in.]), respectively, for each of the three stations (Arguez and others, 2010).

The Federal Coal Management Program (1979) noted that annual potential evaporation in the San Juan River coal region to be at least six times the annual precipitation rate, and elsewhere estimated potential evapotranspiration in this region to range between $600 \mathrm{~mm}$ to $989 \mathrm{~mm}$ (24 in. to $35 \mathrm{in}$.). The annual average pan evaporation rate, a measure of evaporation from still water, was measured to be $1,697 \mathrm{~mm}$ (66.81 in., $5.6 \mathrm{ft}$, or about 13 times the average of precipitation rates reported in the preceding paragraph) between 1978 and 2005 at Farmington, N. Mex. (Western Regional Climate Center, 2016).

\section{Land Uses in the Study Area}

Land uses within the study area include irrigated farming (Roybal and others, 1983); cattle and sheep ranching; wildlife habitat; and industrial, commercial, residential, and recreational activities. Industries within the study area include widespread oil and gas extraction, coal mining, and electrical power generation (MMD, 2017b).

In the study area, water for domestic, agricultural, recreational, industrial, and commercial uses is obtained from the San Juan River and from groundwater sources (San Juan Water Commission, 2003). Wells completed in alluvial groundwater systems are in use in the San Juan and La Plata Valleys. A few wells are completed in deeper strata as reported in the New Mexico Water Rights Reporting System (WRRS) database (New Mexico Office of the State Engineer [NMOSE], 2014a). The WRRS-listed wells are approved to divert groundwater for domestic use, livestock watering, and irrigation. In general, water for irrigated agriculture is diverted from the San Juan, Animas (outside of the study area), or La Plata Rivers into irrigation ditches that are generally unlined (Otten, 1977) and are managed by irrigation organizations (Saavedra, 1987).

\section{Industrial Activities}

\section{San Juan Generating Station}

The SJGS is a mine-mouth generating station (MMD, 2014a), which is defined as "a coal burning electricgenerating plant built near a coal mine” (Kentucky Mining Institute, 2014). The SJGS was sited adjacent to strippable parts of the coal outcrop in the Fruitland Formation (fig. 1A; U.S. Southwest Energy Federal Task Force [SW Energy], 1972). Construction of the SJGS began in early 1970 and was completed in 1982 (Nickelson, 1988; Public Service Company of New Mexico, 2014). During the early phases of construction, a pond, located south of the SJGS, fig. 1B) was constructed to store at least $5.24 \times 10^{6}$ cubic meters $\left(\mathrm{m}^{3}\right)$ $(4,250$ acre-ft) of fresh untreated (raw) water diverted through diversion points in the San Juan River from a reservoir located outside of the study area. Surface mining started in 1973 (MMD, 2017a).

During the period of study (2010-13), the SJGS power plant used four coal-fired boiler units with a capacity of 1,848 megawatts to transmit power through a network of high-voltage power lines (Mercier, 2010); however, the Public Service Company of New Mexico (2014) reports a capacity of 1,646 megawatts. The original approved mining plan (SW Energy, 1972, appendix K) indicates that about 555 metric tons (612 short tons) of ash will be produced annually for every megawatt of power produced. The SJGS uses about 16,330 metric tons (18,000 short tons) of coal per day (Mercier, 2010). In addition to the power plant, the SJGS infrastructure includes service buildings; cooling towers; and effluent, evaporation, and stormwater collection ponds (collectively called process ponds).

Two Superfund investigations of the SJGS were undertaken between the late 1970s and 1990s. Both investigations were closed with findings of "no further remedial actions planned” (U.S. Environmental Protection Agency [EPA], 2014).

\section{San Juan Mine}

The SJM was operated by the San Juan Coal Company, a subsidiary of New Mexico Coal, which in turn was owned by BHP Billiton during the period of this study. The SJM was operated previously by Western Coal Company and Utah International Inc. (Nickelson, 1988) and was owned by Westmoreland Coal Company after February 2016 (Westmoreland Coal Company, 2016). The SJM began operation as a surface coal strip mine in 1973, following approval of an Environmental Impact Assessment (EIA) by the U.S. Office of Surface Mining; a second EIA, regarding expansion of the SJGS, was approved in 1976 (Nickelson, 1988). Coal was surface mined at SJM at an average rate of about 4.2 million metric tons (5 million short tons) per year (statistic for the period between 1982 and 1986, according to Nickelson, 1988). Surface mining was permitted through 1999 (Mercier, 2010; MMD, 2014a).

Coal production was shifted to underground mining in October 2002 (Mercier, 2010). Between 1986 and 2002, supplementary coal was brought to the SJGS from the La Plata Mine (LPM), located in the northernmost part of the study area (location approximated by LPMKPC1 well, fig. 1A; table 1). Underground mining operations at the SJM were halted between September 2011 and June 2012 because of an underground mine fire (U.S. Securities and Exchange Commission, 2011). 
Table 1. Locations, water-bearing units of completion, and completion details of monitoring wells at or in the vicinity of the San Juan Mine, San Juan County, New Mexico.

[short well name, key to wells plotted in figure 1; NAD 83, North American Datum of 1983; NAVD 88, North American Vertical Datum of 1988; m, meter; $\mathrm{ft}$, foot; well depth, in relation to land surface elevation; open interval depth in relation to land surface elevation; Primary aquifer code, as recorded in U.S. Geological Survey groundwater site inventory database; 110ALVM, Quaternary Alluvium; 110NTGU, Naha and Tsegi eolian deposits (undifferentiated); 111CRMS, Covered/Reclaimed Mine Spoil; 111CRMSA, Covered/Reclaimed Mine Spoil and Ash; 111SPOL, Spoil; 211FRLD, Fruitland Formation; 211PCCF, Pictured Cliffs Sandstone; --, unknown or not available]

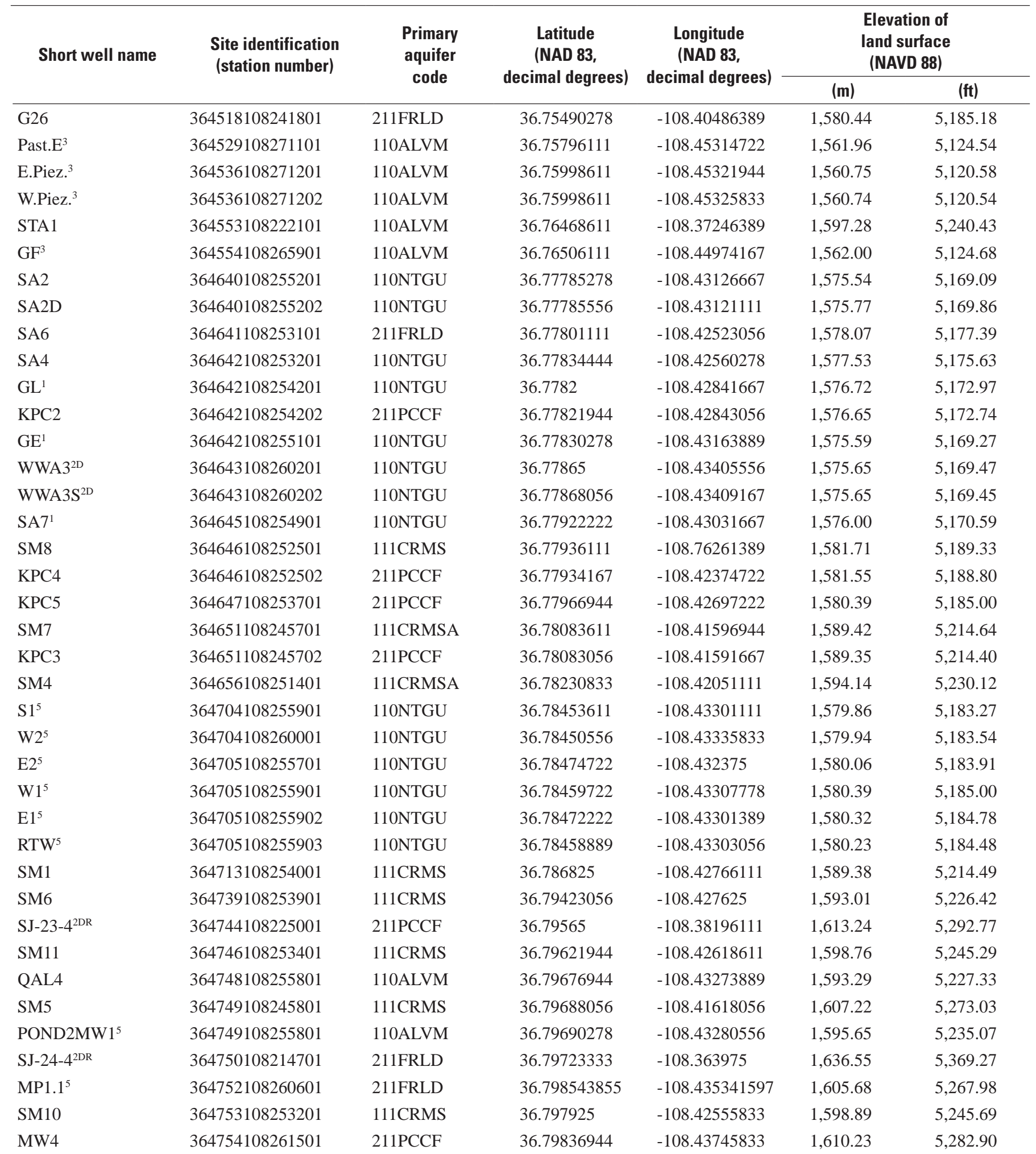


Table 1. Locations, water-bearing units of completion, and completion details of monitoring wells at or in the vicinity of the San Juan Mine, San Juan County, New Mexico.-Continued

[short well name, key to wells plotted in figure 1; NAD 83, North American Datum of 1983; NAVD 88, North American Vertical Datum of 1988; m, meter; $\mathrm{ft}$, foot; well depth, in relation to land surface elevation; open interval depth in relation to land surface elevation; Primary aquifer code, as recorded in U.S. Geological Survey groundwater site inventory database; 110ALVM, Quaternary Alluvium; 110NTGU, Naha and Tsegi eolian deposits (undifferentiated); 111CRMS, Covered/Reclaimed Mine Spoil; 111CRMSA, Covered/Reclaimed Mine Spoil and Ash; 111SPOL, Spoil; 211FRLD, Fruitland Formation; 211PCCF, Pictured Cliffs Sandstone; --, unknown or not available]

\begin{tabular}{|c|c|c|c|c|c|c|c|c|c|c|}
\hline \multirow[t]{2}{*}{ Short well name } & \multicolumn{2}{|c|}{$\begin{array}{l}\text { Measuring } \\
\text { point height }\end{array}$} & \multicolumn{2}{|c|}{$\begin{array}{c}\text { Measuring } \\
\text { point elevation } \\
\text { (NAVD 88) }^{7}\end{array}$} & \multicolumn{2}{|c|}{ Well depth } & \multicolumn{2}{|c|}{$\begin{array}{l}\text { Open interval } \\
\text { depth } \\
\text { (m) }\end{array}$} & \multicolumn{2}{|c|}{$\begin{array}{l}\text { Open interval } \\
\text { depth } \\
\text { (ft) }\end{array}$} \\
\hline & $(\mathrm{m})$ & (ft) & (m) & (ft) & (m) & (ft) & Top & Bottom & Top & Bottom \\
\hline G26 & 0.91 & 3.00 & $1,581.36$ & $5,188.18$ & 36.3 & 119 & 30.18 & 36.27 & 99.00 & 119.00 \\
\hline Past. $E^{3}$ & 0.00 & 0.00 & $1,561.96$ & $5,124.54$ & 5.5 & 18 & -- & -- & -- & -- \\
\hline E.Piez. ${ }^{3}$ & 0.00 & 0.00 & $1,560.75$ & $5,120.58$ & 5.8 & 19 & -- & -- & -- & -- \\
\hline STA1 & 0.90 & 2.95 & $1,598.18$ & $5,243.38$ & 2.7 & 9 & 1.52 & 2.74 & 5.00 & 9.00 \\
\hline $\mathrm{GF}^{3}$ & 0.27 & 0.90 & $1,562.28$ & $5,125.58$ & 11.6 & 38 & 5.49 & 11.58 & 18.00 & 38.00 \\
\hline SA2 & 0.90 & 2.95 & $1,576.44$ & $5,172.04$ & 7.0 & 23 & 3.96 & 7.01 & 13.00 & 23.00 \\
\hline SA2D & 0.85 & 2.80 & $1,576.63$ & $5,172.66$ & 8.3 & 27.3 & 6.71 & 8.23 & 22.00 & 27.00 \\
\hline SA6 & 0.98 & 3.20 & $1,579.04$ & $5,180.59$ & 10.4 & 34 & 8.84 & 10.36 & 29.00 & 34.00 \\
\hline $\mathrm{GE}^{1}$ & 0.00 & 0.00 & $1,575.59$ & $5,169.27$ & 12.2 & 40 & 6.10 & 12.19 & 20.00 & 40.00 \\
\hline $\mathrm{WWA3}^{2 \mathrm{D}}$ & 0.82 & 2.70 & $1,576.48$ & $5,172.17$ & 10.5 & 34.4 & 4.27 & 10.36 & 14.00 & 34.00 \\
\hline WWA3S ${ }^{2 \mathrm{D}}$ & 0.76 & 2.50 & $1,576.41$ & $5,171.95$ & 7.4 & 24.4 & 4.27 & 7.32 & 14.00 & 24.00 \\
\hline SA $7^{1}$ & 0.99 & 3.25 & $1,576.99$ & $5,173.84$ & 8.5 & 28 & 2.44 & 8.53 & 8.00 & 28.00 \\
\hline SM8 & 0.81 & 2.65 & $1,582.52$ & $5,191.98$ & 4.9 & 16 & 2.74 & 4.27 & 9.00 & 14.00 \\
\hline KPC4 & 0.84 & 2.75 & 1,582.38 & $5,191.55$ & 21.3 & 70 & 15.24 & 21.34 & 50.00 & 70.00 \\
\hline KPC5 & 0.90 & 2.95 & $1,581.29$ & 5,187.95 & 24.4 & 80 & 18.29 & 24.38 & 60.00 & 80.00 \\
\hline SM7 & 0.78 & 2.55 & $1,590.20$ & $5,217.19$ & 43.5 & 142.7 & 36.58 & 42.67 & 120.00 & 140.00 \\
\hline КРСЗ & 0.87 & 2.85 & $1,590.22$ & $5,217.25$ & 64.6 & 212 & 52.43 & 64.62 & 172.00 & 212.00 \\
\hline RTW $^{5}$ & 0.79 & 2.60 & $1,581.02$ & $5,187.08$ & -- & -- & -- & -- & -- & -- \\
\hline SM1 & 0.40 & 1.30 & 1,589.77 & $5,215.79$ & 17.9 & 58.8 & -- & -- & -- & -- \\
\hline SM6 & 1.07 & 3.50 & $1,594.08$ & $5,229.92$ & 14.3 & 47 & 8.23 & 14.33 & 27.00 & 47.00 \\
\hline SJ-23-4 ${ }^{2 \mathrm{DR}}$ & 0.61 & 2.00 & $1,613.85$ & $5,294.77$ & 222.4 & 729.5 & 186.84 & 222.35 & 613.00 & 729.50 \\
\hline SM11 & 0.81 & 2.65 & $1,599.57$ & $5,247.94$ & 18.0 & 59 & 11.28 & 17.37 & 37.00 & 57.00 \\
\hline QAL4 & 0.76 & 2.50 & $1,594.05$ & $5,229.83$ & 8.1 & 26.5 & 1.37 & 7.47 & 4.50 & 24.50 \\
\hline SM5 & 0.84 & 2.75 & $1,608.06$ & $5,275.78$ & 66.1 & 217 & 59.74 & 66.45 & 196.00 & 218.00 \\
\hline POND2MW15 & 0.76 & 2.50 & $1,596.41$ & $5,237.57$ & 3.1 & 10.3 & 1.62 & 3.14 & 5.30 & 10.30 \\
\hline SJ-24-4 ${ }^{2 D R}$ & 0.73 & 2.40 & 1,637.29 & $5,371.67$ & 177.4 & 582 & 166.42 & 177.39 & 546.00 & 582.00 \\
\hline MP1. $1^{5}$ & 0.00 & 0.00 & $1,605.68$ & $5,267.98$ & 5.8 & 19 & 1.22 & 4.27 & 4.00 & 14.00 \\
\hline SM10 & 0.81 & 2.65 & 1,599.69 & $5,248.34$ & 18.9 & 62 & 12.19 & 18.29 & 40.00 & 60.00 \\
\hline MW4 & 0.00 & 0.00 & $1,610.23$ & $5,282.90$ & 10.7 & 35 & 7.01 & 10.06 & 23.00 & 33.00 \\
\hline
\end{tabular}


Table 1. Locations, water-bearing units of completion, and completion details of monitoring wells at or in the vicinity of the San Juan Mine, San Juan County, New Mexico.-Continued

[short well name, key to wells plotted in figure 1; NAD 83, North American Datum of 1983; NAVD 88, North American Vertical Datum of 1988; m, meter; $\mathrm{ft}$, foot; well depth, in relation to land surface elevation; open interval depth in relation to land surface elevation; Primary aquifer code, as recorded in U.S. Geological Survey groundwater site inventory database; 110ALVM, Quaternary Alluvium; 110NTGU, Naha and Tsegi eolian deposits (undifferentiated); 111CRMS, Covered/Reclaimed Mine Spoil; 111CRMSA, Covered/Reclaimed Mine Spoil and Ash; 111SPOL, Spoil; 211FRLD, Fruitland Formation; 211PCCF, Pictured Cliffs Sandstone; --, unknown or not available]

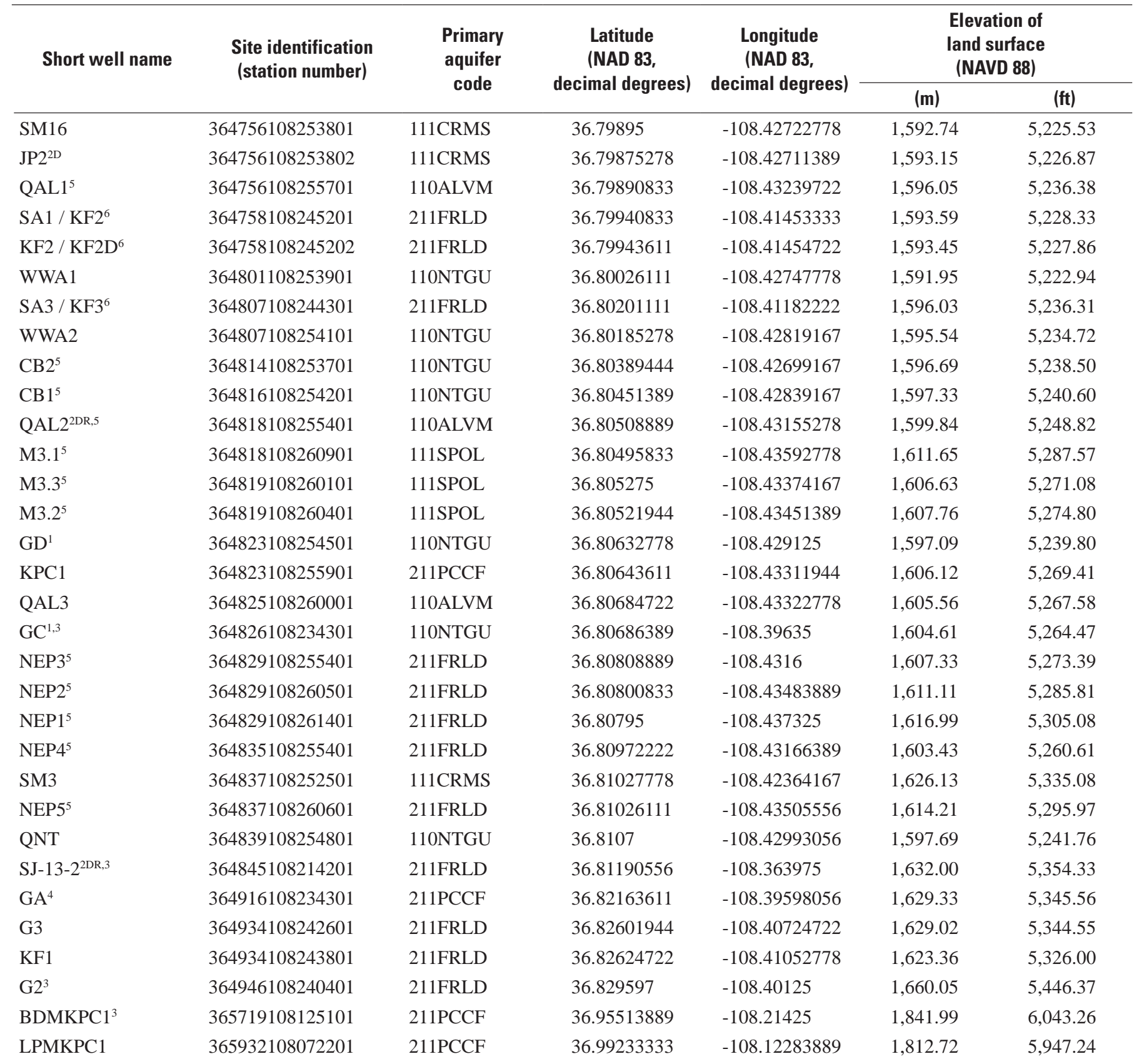


Table 1. Locations, water-bearing units of completion, and completion details of monitoring wells at or in the vicinity of the San Juan Mine, San Juan County, New Mexico.—Continued

[short well name, key to wells plotted in figure 1; NAD 83, North American Datum of 1983; NAVD 88, North American Vertical Datum of 1988; m, meter; $\mathrm{ft}$, foot; well depth, in relation to land surface elevation; open interval depth in relation to land surface elevation; Primary aquifer code, as recorded in U.S. Geological Survey groundwater site inventory database; 110ALVM, Quaternary Alluvium; 110NTGU, Naha and Tsegi eolian deposits (undifferentiated); 111CRMS, Covered/Reclaimed Mine Spoil; 111CRMSA, Covered/Reclaimed Mine Spoil and Ash; 111SPOL, Spoil; 211FRLD, Fruitland Formation; 211PCCF, Pictured Cliffs Sandstone; --, unknown or not available]

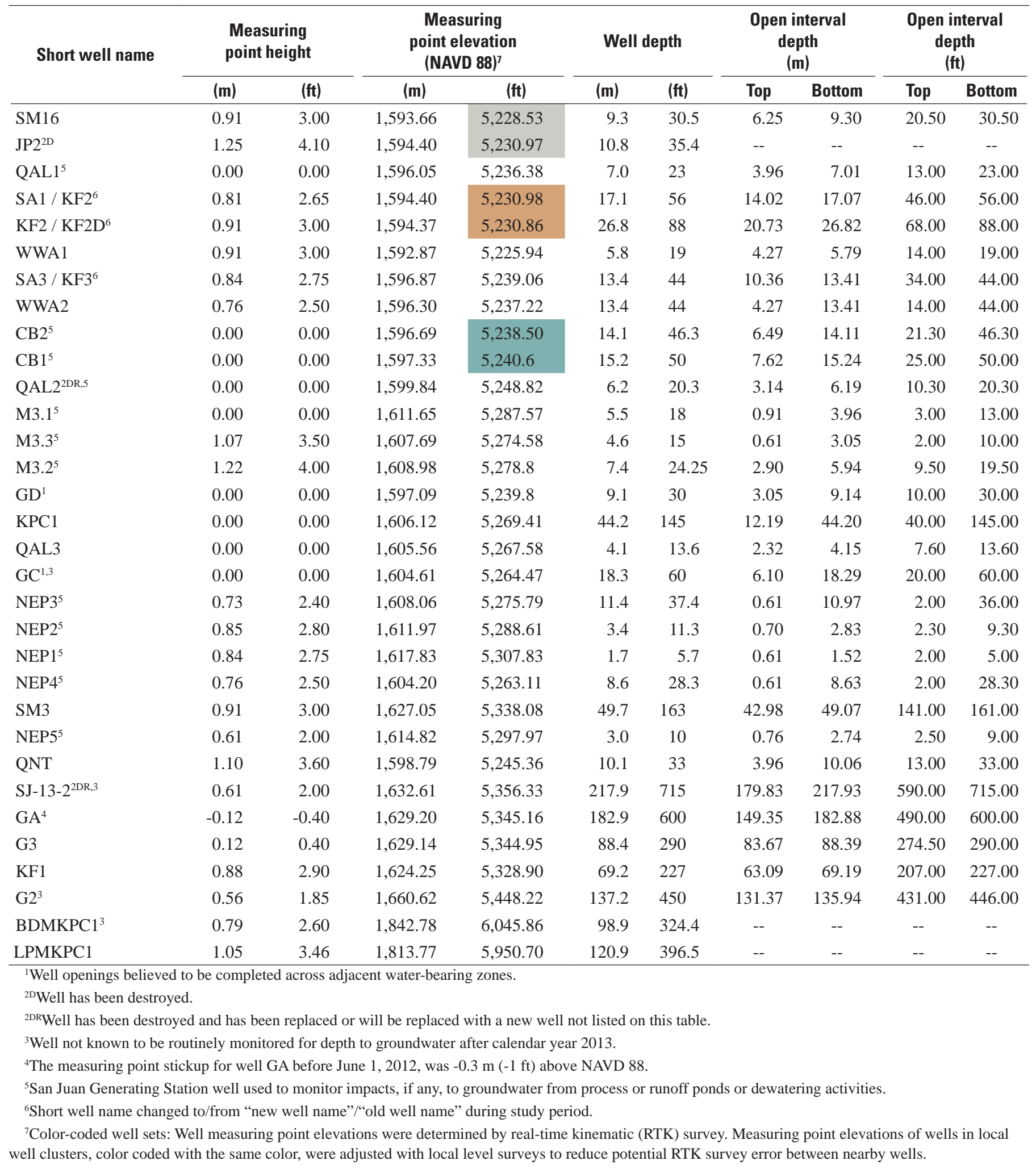


The surface of the SJM active mining area contains service buildings; equipment storage areas; light-duty roads and heavy-duty haul roads; reclaimed and unreclaimed surface-mined pits; temporary ponds; above-ground heavyduty power lines and buried water lines; coal handling facilities; stock piles of coal, mine spoil, and top soil; and, of course, access portals to the underground mine.

Water produced from surface-mining pits was stored in various ponds, and part of the water was recycled for various uses (Mining and Minerals Division of New Mexico Energy, Minerals and Natural Resources Department, written commun., 2010; NMOSE, 2014a). Groundwater is estimated to flow into the underground mine at an average rate between 453 cubic meters per day $\left(\mathrm{m}^{3} / \mathrm{d}\right)(0.37$ acre-ft/d or 134 acre-ft/yr; MMD, 2017b) and 608 m³/d (0.5 acre-ft/d or 179 acre-ft/yr; Parker, 2011). For the period between January 2006 and March 2009, the actual rate was reported to be $257 \mathrm{~m}^{3} / \mathrm{d}$ (0.21 acre-ft/d or 76 acre-ft/yr) (MMD, 2017b) or about 56.7 percent of the lowest estimated rate.

Excavated surface-mining pits are used for storing CCB ash (fig. 1A). The CCBs are hauled from the SJGS and interbedded with mine spoil (poorly graded pulverized overburden collected and stored during surface mining; James O’Hara, Director, Mining and Minerals Division of New Mexico Energy, Minerals and Natural Resources Department, oral commun., September 13-17, 2010). When the pits are full they are covered with top soil and revegetated according to the reclamation plan described in the original approved mining plan (SW Energy, 1972).

\section{Other Coal Mining Activities}

The Black Diamond Mine (BDM) and the LPM are located in the northern part of the study area (locations approximated by wells BDMKPC1 and LPMKPC1, respectively, fig. 1A) (MMD, 2014b, c). The BDM is privately owned and was not in operation during the present study. The LPM is owned and operated by San Juan Coal Company and had been closed and reclaimed prior to this study. Coal mined at LPM was hauled to the SJGS from late 1986 through 2002 (Nickelson, 1988; Mercier, 2010); thus, CCBs generated from LPM coal composes part of the CCBs stored at SJM. At LPM, the mineable coal seam dipped as much as 32 degrees to the south and contained 0.9 percent sulfur and 22 percent ash (18 to 25 percent, according to Luther and others, 2005). At SJM, the reported 1986 mining rate of 5.2 million tons per year (Nickelson, 1988) was updated by Luther and others (2005) to be 7 million tons per year (6,400,000 metric tons) in 2005 .

\section{Oil and Natural Gas Well Pumping}

Oil and gas were discovered in the San Juan Basin around 1910 and have continued to be developed (Parker and others,
1977). At the time of writing (2014), the GOTECH internet database provided more than 12,000 oil and gas well field records for active wells in San Juan County (GO-TECH, 2014, 2016). Oil and gas wells operated in the San Juan Basin are assumed to drawdown and decrease the confining pressure of groundwater.

\section{Other Land Uses}

Residential and commercial land uses are focused in the municipalities of Fruitland, Kirtland, and La Plata, N. Mex. (fig. 1B), whereas irrigated agriculture and ranching is generally located near the San Juan and La Plata Rivers (fig. 1B). Water for residential, agricultural, and commercial uses is increasingly obtained from the San Juan River. In the vicinity of the SJM, water for irrigated agriculture is diverted from the San Juan or La Plata Rivers, or from sources outside the study area, into unlined irrigation ditches (Otten, 1977) that are managed by irrigation organizations (Saavedra, 1987).

\section{Previous Descriptions of the Hydrogeologic Setting}

Irwin (1966) summarized the hydrology and water supplies of the Ute Mountain Ute Tribal lands of northwestern New Mexico (fig. 1B) in and adjacent to the northernmost and westernmost parts of the study area. Fassett and Hinds (1971) reported on the geology and fuel resources of the Fruitland Formation and Kirtland Shale of Cretaceous age. Kelly (1957) described the tectonics of the San Juan Basin, a subject revisited by Woodward and Callendar (1977). Molenaar (1977) described the stratigraphy of Late Cretaceous rocks, including formations of interest for this work. Lyford (1979) described San Juan Basin aquifers and groundwater. Wright (1979) identified and catalogued San Juan Basin geologic and hydrologic reports into a bibliography that, with preceding work, became an important reference for later workers. Niemczyk and Walters (1980) evaluated the potential for impacts to water chemistry from methane extraction. Frenzel and Lyford (1982) estimated vertical saturated hydraulic conductivity and regional groundwater-flow rates of the San Juan Basin. Hejl (1982) summarized hydrologic investigations in strippable coal areas of northwestern New Mexico. Klausing and Welder (1984) reported on the locations of springs, the locations and completion details of water wells, and the locations and recorded discharge data of streamgages in San Juan County, N. Mex. Myers and Villanueva (1986) considered potential impacts on groundwater from surface mining of coal from the Fruitland Formation. 
Stone and others (1983) reported comprehensively on San Juan Basin regional-scale hydrology and water resources. Roybal and others (1983) summarized the physiography and hydrologic characteristics of parts of the San Juan Basin including the study area. Ayers and Kaiser (1994) edited a compendium on coal-bed methane extraction in the central San Juan Basin that included several reports on hydrologic conditions. Levings and others (1996) conducted the San Juan Basin regional aquifer-system analysis (RASA) study for the USGS. The RASA products included a set of 10 hydrologic atlases, one for each major formation in the San Juan Basin (Craigg and others, 1989, 1990; Dam and others, 1990a, b; Levings and others, 1990a, b; Kernodle and others, 1989, 1990; Thorn and others, 1990a, b). Oldaker (1991) summarized the hydrogeologic characteristics of the coal beds and sandstone lenses in the Fruitland Formation. The EPA (2004) summarized results of regional-scale, LateCretaceous age Fruitland Formation coal-bed and related coalbed methane extraction studies and related water chemistry and hydrological findings. Kernodle (1996) developed and reported results of the RASA steady-state numerical groundwater model of the San Juan Basin. Craigg (2001) developed and reported results of the RASA regional-scale geological-framework study of the San Juan Basin. Metric Corporation issued a series of consultant reports focused on the SJGS. Their final groundwater resource investigation report characterized water-bearing formations and provided information and data regarding water chemistry, infrastructure water leaks and associated mitigation (if any), and past and present generalized water balances for the SJGS (Metric Corporation, 2007). Mercier (2010) updated a description of historic and current coal-mining and power generation in the present study area. Stewart and Thomas (2015) and Stewart $(2017,2018)$ collected and summarized hydrologic data from wells located within the study area.

\section{Geologic History and Structure}

The San Juan Basin is located in northwestern New Mexico and southwestern Colorado, extending into Arizona and Utah (Fassett and Hinds, 1971; Craigg, 2001). Synclinal basin subsidence started about 70 million years ago (Late Cretaceous) and ended about 35 million years ago (Kelly, 1957; Molenaar, 1977; Kernodle, 1996; Craigg, 2001). Prior to and during basin subsidence, Precambrian-age igneous and metamorphic rocks were overlain successively by Triassic-, Jurassic-, Cretaceous-, and Tertiary-age sedimentary rocks with a total thickness of as much as 4,265 m (14,000 ft) (Levings and others, 1996). The lowest point of the basin is located east of the present study area (Craigg, 2001).

Structural geologic features such as platforms, monoclinal and anticlinal uplifts, sags, and other subsidence features are present along the basin margins (Craigg, 2001) as well as associated fault zones (mapped by Taylor and Huffman, 1998). Along parts of the western, northern, and eastern basin margins, uplifted rock strata dip steeply inward toward low points of the basin, whereas along the southern basin margin, strata dip gently inward (Kelly, 1957, Stone and others, 1983; Ayers and others, 1994; Kernodle, 1996; Craigg, 2001), yielding asymmetric basin structure. Surficially, the oldest rocks of the San Juan Basin crop out along the basin margins, rocks of decreasing age crop out concentrically, and successively younger rocks crop out toward the basin interior. The central basin (fig. $1 A$ ) is located in the interior of the San Juan Basin and is bounded along its western, northwestern, and northern margins by the Hogback monocline (Craigg, 2001), which is crested by Late Cretaceous-age sandstone beds that display increased faulting with proximity to the monocline (Kelly, 1957; Stone and others, 1983; Ayers and others, 1994; Craigg, 2001). The study area is located along the northwestern margin of the central basin, along one of several shorelines of the Late Cretaceous-age Western Interior Seaway; in the study area, the shoreline was oriented in a northwest to southeast direction. During basin subsidence, the seaway was subject to as many as four to five transgressiveregressive cycles (Molenaar, 1977; Laubach and Tremain, 1994). The combination of basin subsidence with seaway regression yielded thick sequences of interbedded marine sandstones and shales with overlying continental coal beds and shales deposited after the final regression (Ayers and others, 1994; Ayers and Zellers, 1994). The continental deposits, coal beds, and underlying rock units within the present study area are described in greater detail in the section entitled "Hydrostratigraphic Framework of the Study Area."

\section{Hydrologic Assessment of the San Juan Mine Study Area}

\section{Surface-Water System}

All natural surface drainage in the study area is toward the San Juan River. La Plata River drains the largest watershed in the study area; La Plata River flows intermittently from north to south and joins the San Juan River near the southeastern corner of the study area. The two main watersheds that traverse the SJM and SJGS are the Westwater and Shumway Arroyo (ephemeral stream channel) systems. (In this report, the term "arroyo" is used equivalently with the term "ephemeral stream channel" when channel local names include the term "arroyo"). The surface courses of the Westwater and Shumway Arroyos eroded through the Cliff House Sandstone at and near the crest of the Hogback monocline and may receive runoff from rainfall events west of the Hogback monocline. Smaller watersheds in the study area, but generally outside of the active mining area, include the Stevens, Coolidge, Dain, and Locke Arroyos (fig. 1B). 


\section{San Juan and La Plata Rivers}

Within the study area, the La Plata River, reported by Oldaker (1991) as perennial, currently (2014) flows intermittently (Michael Carlson, U.S. Geological Survey, oral commun., 2014). The La Plata River flows south from the Colorado-New Mexico border to its confluence with the San Juan River near the southeastern corner of the study area. The San Juan River flows perennially from east to west in the study area (figs. $1 A$ and $1 B$ ). Tributaries to La Plata and San Juan Rivers in the study area are generally ephemeral, flowing only in response to precipitation events. The San Juan and La Plata Rivers and alluvial groundwater systems are important sources of drinking and irrigation water in the study area.

A mean annual streamflow of 4,902,000 m³/d (2,004 cubic feet per second [ $\left.\mathrm{ft}^{3} / \mathrm{s}\right]$ ) along the perennially flowing San Juan River (as gaged at the long-term USGS streamgage 09365000 San Juan River at Farmington, N. Mex.) appears to be generally consistent with the long-term mean annual streamflow at USGS streamgage 09368000 San Juan River at Shiprock, N. Mex. The relatively large mean annual streamflow observed in the 3-year record at USGS streamgage 09367540 San Juan River near Fruitland, N. Mex. (located between the other two streamgages) was assumed to be represented in the mean annual flows for the 80 -year and 78-year, respectively, periods of record of the Farmington and Shiprock streamgages (table 2). Average streamflow discharge along the La Plata River varies between $27,000 \mathrm{~m}^{3} / \mathrm{d}$ and $64,600 \mathrm{~m}^{3} / \mathrm{d}\left(11 \mathrm{ft}^{3} / \mathrm{s}\right.$ and $\left.26 \mathrm{ft}^{3} / \mathrm{s}\right)$; at USGS streamgage 09366500 La Plata River at Colorado-New Mexico State line, a short period of record was recorded with an average streamflow discharge of 53,700 m³ $/ \mathrm{d}^{2}\left(2 \mathrm{ft}^{3} / \mathrm{s}\right.$ ) (table 2; USGS NWIS, 2012-14). The San Juan River alluvium and multiple shallow wells, which draw from that system, are potential hydrologic receptors of particles that may migrate from CCB storage areas at the SJM.

\section{Westwater and Shumway Arroyos}

The SJM active mining area is located within the watersheds of the Westwater and Shumway Arroyo systems (fig. 1B). Along the western boundary of the SJM lease area, the Shumway Arroyo flows intermittently, but prior to the initiation of industrial and agricultural activities in the area, flow was ephemeral in response to precipitation events (Myers and Villanueva, 1986). The Westwater Arroyo is a major tributary to the Shumway Arroyo in the vicinity of the SJGS. The natural Westwater Arroyo trended from the upgradient Hogback source areas north and northwest of the SJGS on a south-southeasterly course, and at the present location of the SJGS, the arroyo turned and trended in a southerly direction to its confluence with the Shumway Arroyo. The natural Shumway Arroyo trended from the upgradient Hogback source

Table 2. Mean annual gaged streamflow for U.S. Geological Survey streamgages in the vicinity of the San Juan Mine, San Juan County, New Mexico.

[m³/d, cubic meter per day; ft³/s, cubic foot per second; USGS, U.S. Geological Survey; NAD 83, North American Datum of 1983; NAD 27, North American Datum of 1927; nr, near]

\begin{tabular}{|c|c|c|c|c|c|c|c|}
\hline \multirow{2}{*}{$\begin{array}{c}\text { Gage } \\
\text { identification }\end{array}$} & \multirow{2}{*}{ Gage name } & \multirow{2}{*}{ Latitude } & \multirow{2}{*}{ Longitude } & \multirow{2}{*}{ Datum } & \multirow{2}{*}{$\begin{array}{c}\text { Period of record } \\
\text { (for complete water } \\
\text { years, October- } \\
\text { September) }\end{array}$} & \multicolumn{2}{|c|}{$\begin{array}{c}\text { Mean annual } \\
\text { gaged streamflow }\end{array}$} \\
\hline & & & & & & $\mathrm{m}^{3 / d}$ & $\mathrm{ft}^{3} / \mathrm{s}$ \\
\hline USGS 09365000 & $\begin{array}{l}\text { San Juan River at } \\
\text { Farmington, N. Mex. }\end{array}$ & 36.72302 & -108.22559 & NAD 83 & $\begin{array}{l}\text { October } 1931 \text { to } \\
\text { September } 2011\end{array}$ & $4,902,000$ & 2,004 \\
\hline USGS 09367540 & $\begin{array}{l}\text { San Juan River near } \\
\text { Fruitland, N. Mex. }\end{array}$ & 36.74028 & -108.40250 & NAD 27 & $\begin{array}{l}\text { October } 1977 \text { to } \\
\text { September } 1980 \\
\text { (3 water years) }\end{array}$ & $6,218,700$ & 2,542 \\
\hline USGS 09368000 & $\begin{array}{l}\text { San Juan River at } \\
\text { Shiprock, N. Mex. }\end{array}$ & 36.77667 & -108.68306 & NAD 83 & $\begin{array}{l}\text { October } 1934 \text { to } \\
\text { September } 2012\end{array}$ & $4,892,000$ & 2,000 \\
\hline USGS 09366500 & $\begin{array}{l}\text { La Plata River at } \\
\text { Colorado-New Mexico } \\
\text { State Line }\end{array}$ & 36.99972 & -108.18806 & NAD 27 & $\begin{array}{l}\text { October } 1999 \text { to } \\
\text { September } 2000 \\
\text { (1 water year) }\end{array}$ & 53,700 & 22 \\
\hline USGS 09367000 & $\begin{array}{l}\text { La Plata River at La } \\
\text { Plata, N. Mex. }\end{array}$ & 36.93092 & -108.18464 & NAD 83 & $\begin{array}{l}\text { October } 2003 \text { to } \\
\text { September } 2012\end{array}$ & 27,000 & 11 \\
\hline USGS 09367500 & $\begin{array}{l}\text { La Plata River near } \\
\text { Farmington, N. Mex. }\end{array}$ & 36.73758 & -108.25034 & NAD 83 & $\begin{array}{l}\text { October } 1938 \text { to } \\
\text { September } 2011 \\
\text { (1938, 1955, } 1956 \\
\text { water years excluded) }\end{array}$ & 64,600 & 26 \\
\hline
\end{tabular}


areas north and east of the Westwater Arroyo source areas on an arcuate path east of the Westwater Arroyo (fig. $1 B$ ). The Hutch Arroyo, a tributary of the Shumway Arroyo, flowed in a westerly direction from Piñon Mesa to its confluence with the Shumway Arroyo in entrenched Quaternary Naha and Tsegi eolian deposits (USGS, 1963; Strobell and others, 1980).

Between 1981 and 1984, the Westwater and Shumway Arroyos (fig. 1B) were diverted from their natural courses (Kaman Tempo, 1984) to two constructed diversion channels called the Westwater Diversion and the Shumway Diversion, respectively, which route flow through the northern parts of the SJM and SJGS (fig. 1A). The two diversions join near the northern boundary between the SJGS and the SJM. About $100 \mathrm{~m}$ (328 ft) downgradient from the constructed confluence, the merged diversion channel begins to collect water. Metric Corporation (2006) characterized the source of this water as a mix of natural groundwater and underground leakage from SJGS industrial sources. In response, corrective actions were initiated by SJGS that included installation of a groundwater recovery program located at the groundwater recovery trench well (RTW) cluster (fig. 1A, inset 2, centered about the RTW pumping recovery well). The Shumway diversion channel trends in a southerly direction to join with the natural Westwater Arroyo at the southern part of the SJGS, $2 \mathrm{~km}$ (1.25 mi) north of the former natural confluence of the two arroyos (fig. $1 B$ ).

In this report, the main stem of the Westwater Arroyo upgradient from the diversion channels is called the "Westwater Arroyo (upper)" (WWA [upper]). The bypassed reach of the natural Westwater Arroyo is called the "Westwater Arroyo (detached)“ (WWA detached). The part of the natural Westwater Arroyo from the terminus of the Shumway diversion channel to the former natural confluence with the Shumway Arroyo is called the "Westwater Arroyo (lower)" (WWA lower) (fig. 1B).

Prior to and during the construction of the diversion channels, coal was surface mined southeast of the WestwaterShumway natural confluence, and the mined area was later reclaimed. After the Westwater and Shumway diversion channels were constructed, the area north of the previously mined area was surface mined to the extent of the location of the planned underground mining and later reclaimed. Parts of the Shumway and Hutch Arroyos were undermined during mining; those reaches are named "Shumway Arroyo (undermined)" (SA undermined) and "Hutch Arroyo (undermined)” (HA undermined) (fig. 1B). The reclamation fill of the entire area includes mine spoil and CCB ash (fig. 1A).

An area located between the SJM lease boundary and the former confluence of the Westwater and Shumway Arroyos (figs. $1 A$ and $B$ ) was not mined. In this area, the former Shumway Arroyo remains intact (fig. 1B); however, this reach is no longer subject to regional ephemeral runoff because it is hydraulically disconnected from the "Shumway Arroyo (upper)" (SA upper). In this report, this reach is called "Shumway Arroyo backwater reach" (SABR) (fig. 1A, inset 2; fig. $1 B$ ). The natural confluence of the Westwater and Shumway Arroyos is $2 \mathrm{~km}(1.25 \mathrm{mi})$ south of the SJGS (at the joining of the SABR and the WWA (lower) [fig. 1B]). Downgradient from the former confluence (fig. $1 B$ ) the arroyo is called the "Shumway Arroyo (lower)" (SA lower). Groundwater occurrence in the vicinity of the SABR and the WWA (detached) is presented in "Quaternary and Shallow Groundwater System” in the "Groundwater Occurrence” section of this report.

The WWA (lower) and the SA (lower) alluvial groundwater systems are potential hydrologic receptors of particles that may migrate from CCB storage areas at the SJM. Groundwater is recovered from the related alluvial system at the RTW well cluster (fig. $1 A$, inset 2) and is returned to SJGS for treatment and disposal. No other groundwater-extraction wells that may pump from the alluvial system were located during the course of this study.

\section{Natural Ponds, Lakes, Seeps, and Springs}

Several springs are located at the head of Westwater Arroyo just outside of the study area boundary along the Hogback monocline, and several other springs and seeps emerge along the San Juan and La Plata River alluvium (fig. 1B). Several other small intermittent ponds are present in the vicinity of the SJGS and SJM or were mapped prior to development (USGS, 1963).

\section{Industrial Process Ponds}

The SJGS and SJM use constructed ponds for storage of raw water, stormwater, groundwater pumped from mining areas, and brines (at SJGS). A large $\left(592 \times 10^{3}\right.$ square meters $\left[\mathrm{m}^{2}\right]$ or146 acres in area) raw water storage pond located south of the SJGS (fig. 1B) was constructed during the early 1970 s to store at least $5.2 \times 10^{6} \mathrm{~m}^{3}(4,250$ acre-ft) of raw water diverted from the San Juan River (NMOSE, 2014d) for mining and generating station use. The SJGS uses $24.1 \times 10^{6} \mathrm{~m}^{3} / \mathrm{yr}$ $(19,500$ acre-ft/yr) from raw water pond storage (Metric Corporation, 2007). Raw water arriving at the SJGS is primarily used for cooling, but a portion is reused for various power plant operations. Metric Corporation (2007) estimated that $169 \times 10^{3}$ cubic meter per year $\left(\mathrm{m}^{3} / \mathrm{yr}\right)(137 \mathrm{acre}-\mathrm{ft} / \mathrm{yr})$ of water is delivered to SJM through the ash handling system, a portion of which is disposed with stored CCBs (Thomson and others, 2012).

At the SJGS, as dissolved-solids concentrations of process water become too great for reuse, the resulting brines are periodically transferred to evaporation ponds where residual water evaporates (Metric Corporation, 2007), enriching salt concentrations to saturation and eventually to solids. The North Evaporation Pond (NEP, composed of three cells named “ 1 ," " 2 ," and “ 3 ” from west to east) are located on a bluff near to and hydrologically upgradient from the location where the WWA (upper) enters the northern boundary of the SJGS (fig. 1A, inset 1). The monitoring wells NEP3 and NEP4 
are located just southeast and northeast, respectively, of NEP cell 3 and hydrologically upgradient from Well-QNT (fig. $1 A$, inset 1). Well-QNT is the most upgradient monitoring well completed in the WWA (upper) alluvium. In this report, the well name "Well-QNT" is intended to allow readers to easily distinguish between the well and the Qnt formation described in a following section (the designated short well name is "QNT," table 1; fig. 1A, inset 1). The Metric Corporation (2007) noted that breaches in liners of the NEP were repaired during the 1990s and hypothesized that the repairs would be successful if declining water levels in NEP3 and NEP4 monitoring wells continued to decrease. Groundwater levels at NEP3 and NEP4 declined until the latter part of 2007, thereafter generally rose until 2011, and subsequently were fairly stable through the end of the monitoring period (2013). This pattern indicates, in accordance with the hypothesis of the Metric Corporation, that leakage from the NEP may have reoccurred (Metric Corporation, 2006, 2007; Stewart and Thomas, 2015). During the USGS hydrologic assessment, no natural groundwater sources were identified that could explain the rising groundwater levels at NEP3 and NEP4.

\section{Irrigation}

Irrigation is practiced along the Shumway Arroyo at one farm south of the SJGS along the SA (lower), outside of and abutting the western boundary of the mine lease area. The SJM 2009 lease permit documents that land in the permit area "has not been historically used as cropland" (MMD, 2017b). Temporary raw water irrigation ponds have been constructed in various locations on the SJM lease area to support irrigation of reclaimed surface mining pits.

\section{Hydrostratigraphic Structure and Setting of the Central San Juan Basin and the Study Area}

The central San Juan Basin is located within the San Juan Basin and within the San Juan declared groundwater basin (fig. 1A; NMOSE, 2014b). Along the northwestern, northern, and eastern San Juan Basin margins, water-bearing rocks of increasing age crop out with increasing elevation and dip steeply toward the lowest part of the basin. In high-elevation locations, snowpack and associated snowmelt and recharge to groundwater-bearing strata are greatest. Topographically, high points of the oldest water-bearing units of the basin are also present along uplifted areas of the southern margin of the San Juan Basin, although the dip of the beds is shallower towards the basin interior than in the northern part of the basin (Kernodle, 1996; Craigg, 2001). Kaiser and others (1994) noted that low elevations along the southern border relative to other parts of the basin may provide discharge areas for the youngest water-bearing units, depending upon the hydrologic characteristics and hydraulic-head configurations of the units. Groundwater also discharges to springs and to streams that exit the central San Juan Basin, primarily to the San Juan River (Roybal and others, 1983). Groundwater likely also discharges diffusely across large areas by evapotranspiration (Kernodle, 1996) depending upon surface recharge and vegetation types and densities.

Topographically controlled recharge, which may be larger at high elevations where older units of the San Juan Basin crop out, promotes confined groundwater conditions as pressure heads increase with depth (and age) of water-bearing units toward the basin interior. Depending on the pressurehead configurations, upward flow may occur in the central basin. The volume of upward flow depends on the magnitude of hydraulic-head gradients, the aggregate vertical saturated hydraulic conductivity of the layered strata through which flow occurs, and the competence of interbedded confining units (Frenzel and Lyford, 1982; Stone and others, 1983; Kernodle, 1996).

The oldest rock formation included in the study is the Cliff House Sandstone (Kch, fig. 2), which is successively overlain by the Lewis Shale (Kls), the Pictured Cliffs Sandstone (Kpc), the Fruitland Formation (Kf) with associated coal seams including the Number 8 coal seam (Kfn8, which is located at the base of the $\mathrm{Kf}$ and is generally undivided from the Kf), and the Kirtland Shale (Kks) (where undifferentiated, the Kf and Kks are termed the Kkf), all Late Cretaceous in age. The Kks (or, if undifferentiated with the Kf, the Kkf) may be overlain by the (Kernodle, 1996) Tertiary-Cretaceous Animas Formation (TKa), which is composed of an older Cretaceous member and a younger Tertiary member. Where present, the TKa is overlain by the Tertiary-Cretaceous Ojo Alamo Sandstone (TKoa on fig. 2B), where it is present (Kernodle, 1996). In the study area, the TKa underlies the TKoa, where both are present. Depending on local erosional history, either the TKa or the TKoa may underlie the Nacimiento Formation (Tn) of Tertiary age (National Geologic Map Database, 2014). In and along stream channels and in other low-lying areas in the vicinity of the SJM, Strobell and others (1980) mapped Quaternary Naha and Tsegi eolian surficial deposits (undifferentiated Naha-Tsegi deposits are termed Qnt; Hack, 1941; Metric Corporation, 1982; National Geologic Map Database, 2014). Quaternary alluvium (Qal) is present along ephemeral, intermittent, and perennial stream channels and may be incised into preexisting Qnt deposits, where Qnt deposits are mapped (Metric Corporation, 1982; Metric Corporation, 2007). Strobell and others (1980) mapped surficial Pleistocene glacial outwash deposits in parts of the study area (Metric Corporation, 2007). 
In the study area, the Kch and Qal are recognized as important water-bearing units (Stone and others, 1983); however, the great depth to the Kch (greater than about $200 \mathrm{~m}$ [600 ft] at the SJM western boundary, as calculated with Kernodle's 1996 Kch surface elevations), except in recharge areas near the Hogback monocline, likely precludes exploration for its use as a water supply in the SJM vicinity, although some oil and gas wells have been reported to be completed in this unit in eastern parts of the study area (GO-TECH, 2014, 2016). The TKoa is used for groundwater supply east of the study area. The Qal groundwater sources are limited to locations near perennial and intermittently flowing streams in the study area (Stone and others, 1983); in some places, Qal groundwater quality is poor (MMD, 2017b). The $\mathrm{Kpc}$ and $\mathrm{Kf}$ coal seams also bear water of inferior quality (MMD, 2017b).

\section{Hydrostratigraphic Framework of the Study Area}

The following discussion of the hydrostratigraphy of the study area describes the groundwater system as it presently functions (2010-13). The descriptions are derived from existing reports and are organized in ascending stratigraphic order and decreasing rock-age order (fig. 2B). Related interpretations of hydraulic-head relations, shown in figs. 3-12, are based on published potentiometric maps or on measured depth-to-water data (Stewart and Thomas, 2015). Hydraulic characteristics and associated hydraulic parameter values, as found in a search of existing literature, are listed in table 3 . A subset of conservative groundwater-chemistry tracers composed of concentrations of chloride and dissolved solids are included to support or qualify hydraulic head-based interpretations of the hydrologic system(s). Water-chemistry data collected by SJGS, SJM, and other agencies and entities are averaged in table 4 and tabulated in Stewart and Thomas (2015) and Stewart (2017) for the period preceding the present study, which ended in 2013. 


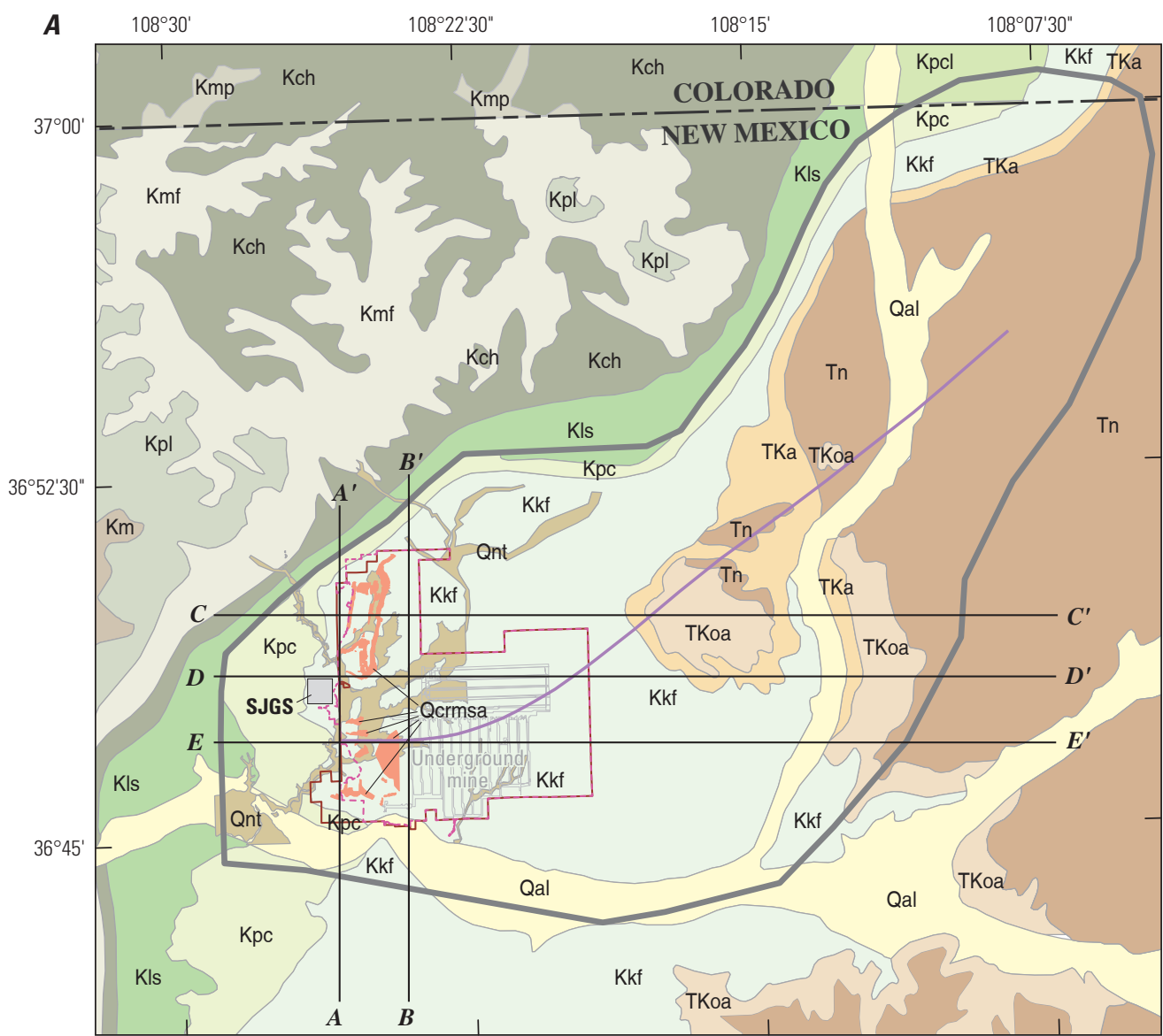

Base modified from U.S. Geological Survey digital data, 2011 Site features from New Mexico Energy, Minerals and Natural Resources Department, Mining and Minerals Division, 2017b

Universal Transverse Mercator, zone 12

North American Datum of 1983

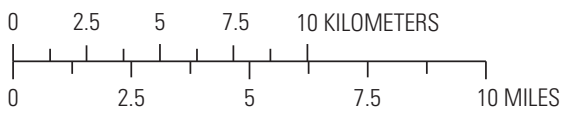

\begin{tabular}{|c|c|c|c|}
\hline & EXPLANATION & & \\
\hline Qal & Alluvium & Kch & Cliff House Sandstone \\
\hline Qnt & Naha and Tsegi eolian deposits (undifferentiated) & Kmf & Menefee Formation \\
\hline Qcrmsa & Ash, covered and reclaimed mine spoil & Kmp & Menefee Formation and Point Lookout \\
\hline $\mathrm{Tn}$ & $\begin{array}{l}\text { Nacimiento Formation-The Nacimiento Formation grades } \\
\text { laterally into the upper part of the Animas Formation }\end{array}$ & $\mathrm{Kpl}$ & $\begin{array}{l}\text { Sandstone (in Colorado) } \\
\text { Point Lookout Sandstone }\end{array}$ \\
\hline TKoa & Ojo Alamo Sandstone & $\mathrm{Km}$ & Mancos Shale \\
\hline TKa & Animas Formation & & San Juan Generating Station (SJGS) \\
\hline Kkf & Kirtland Shale and Fruitland Formation (undifferentiated) & 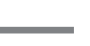 & Study area boundary \\
\hline $\mathrm{Kpc}$ & Pictured Cliffs Sandstone & & San Juan Coal Mine permit area boundary \\
\hline $\mathrm{Kpcl}$ & Pictured Cliffs Sandstone and Lewis Shale (in Colorado) & & San Juan Coal Mine lease area boundary \\
\hline Kls & Lewis Shale & $-C^{\prime}$ & Line of section \\
\hline
\end{tabular}

Note: Locations of mine spoil in reclaimed areas (Qcrms, exact locations unknown and not shown) may be estimated as being bounded by Qcrmsa. Final extent of Qcrms and Qcrmsa is unknown as of 2017

Figure 2. A, Surface geology and $B$, cross sections showing stratigraphy, San Juan Mine and vicinity, San Juan County, New Mexico. 

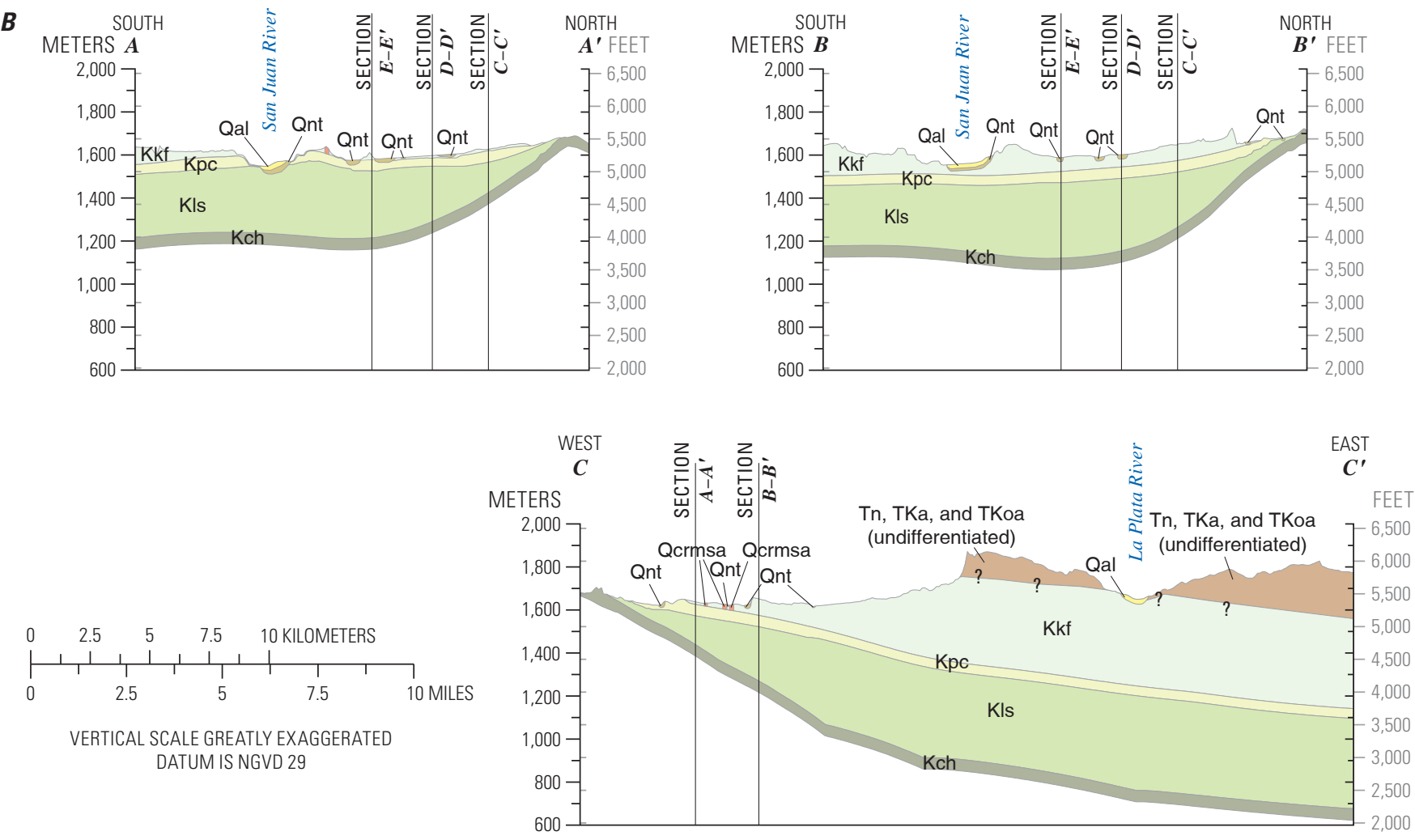

\section{EXPLANATION}

Geology-Queried where depth unknown Alluvium

Naha and Tsegi eolian deposits (undifferentiated)

Ash, covered and reclaimed mine spoil

\begin{tabular}{|c|}
\hline Tn \\
\hline TKoa \\
\hline TKa \\
\hline Kkf \\
\hline Kpc \\
\hline Kls \\
\hline Kch \\
\hline
\end{tabular}

Nacimiento Formation, Ojo Alamo Sandstone, and Animas Formation (undifferentiated)

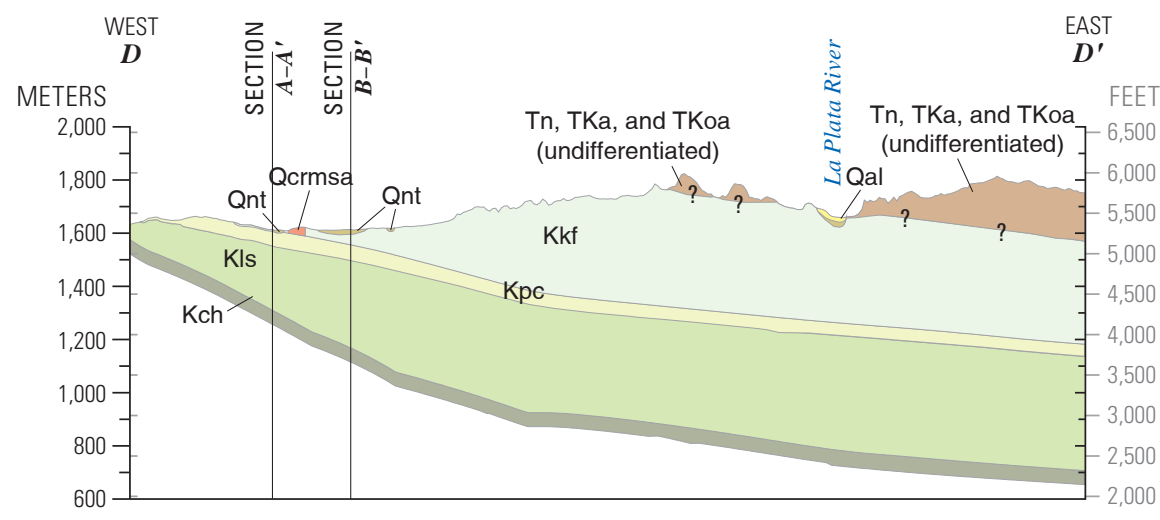

All cross sections terminate vertically at the bottom of the Cliff House Sandstone (Kch), because that formation represents one of the hydrologic boundaries used to bound the numerical model and the study area.

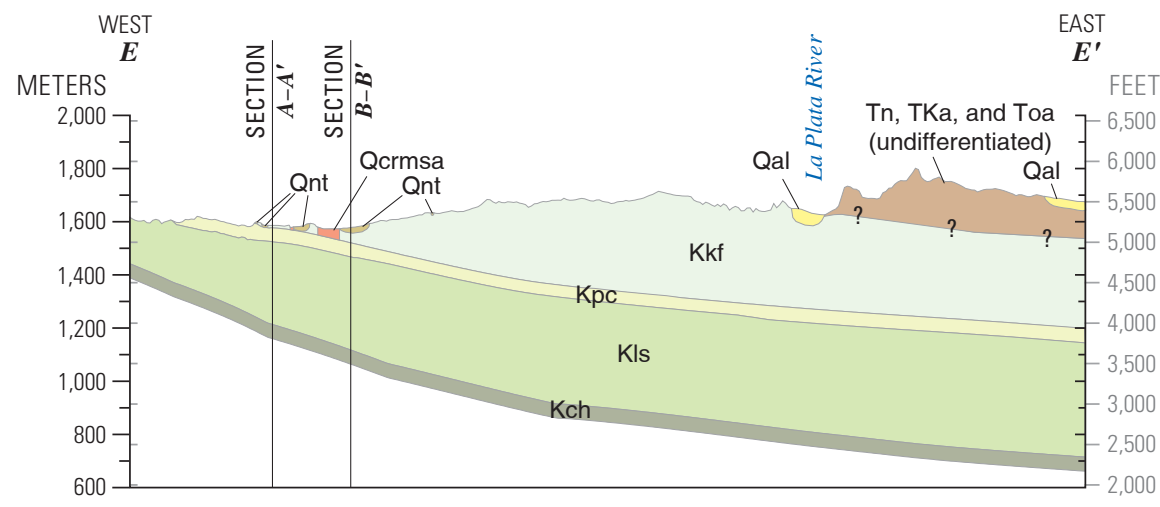

Figure 2. A, Surface geology and $B$, cross sections showing stratigraphy, San Juan Mine and vicinity, San Juan County, New Mexico.-Continued 


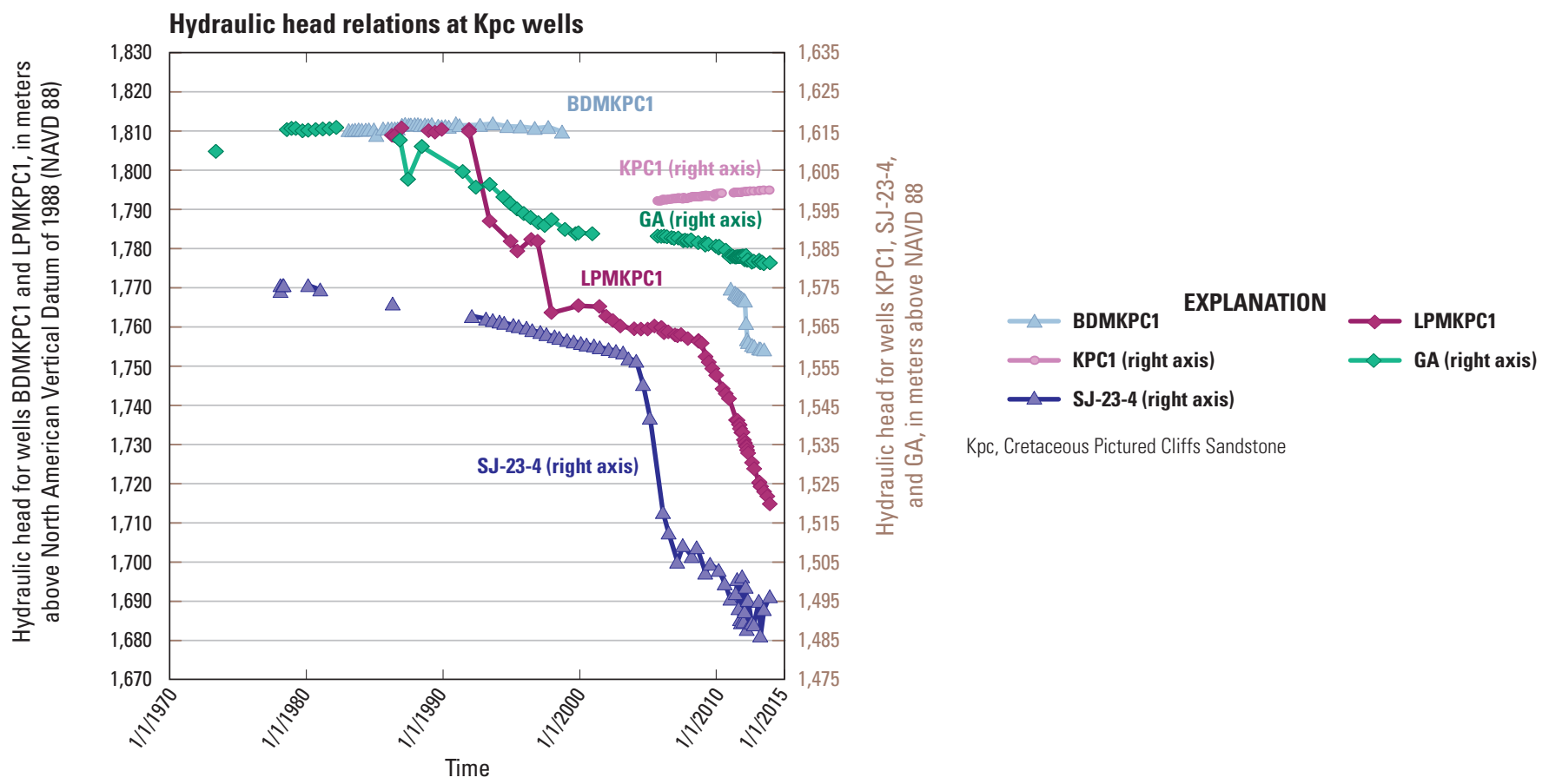

Figure 3. Hydraulic-head relations at long-term period of record Kpc wells, San Juan County, New Mexico.

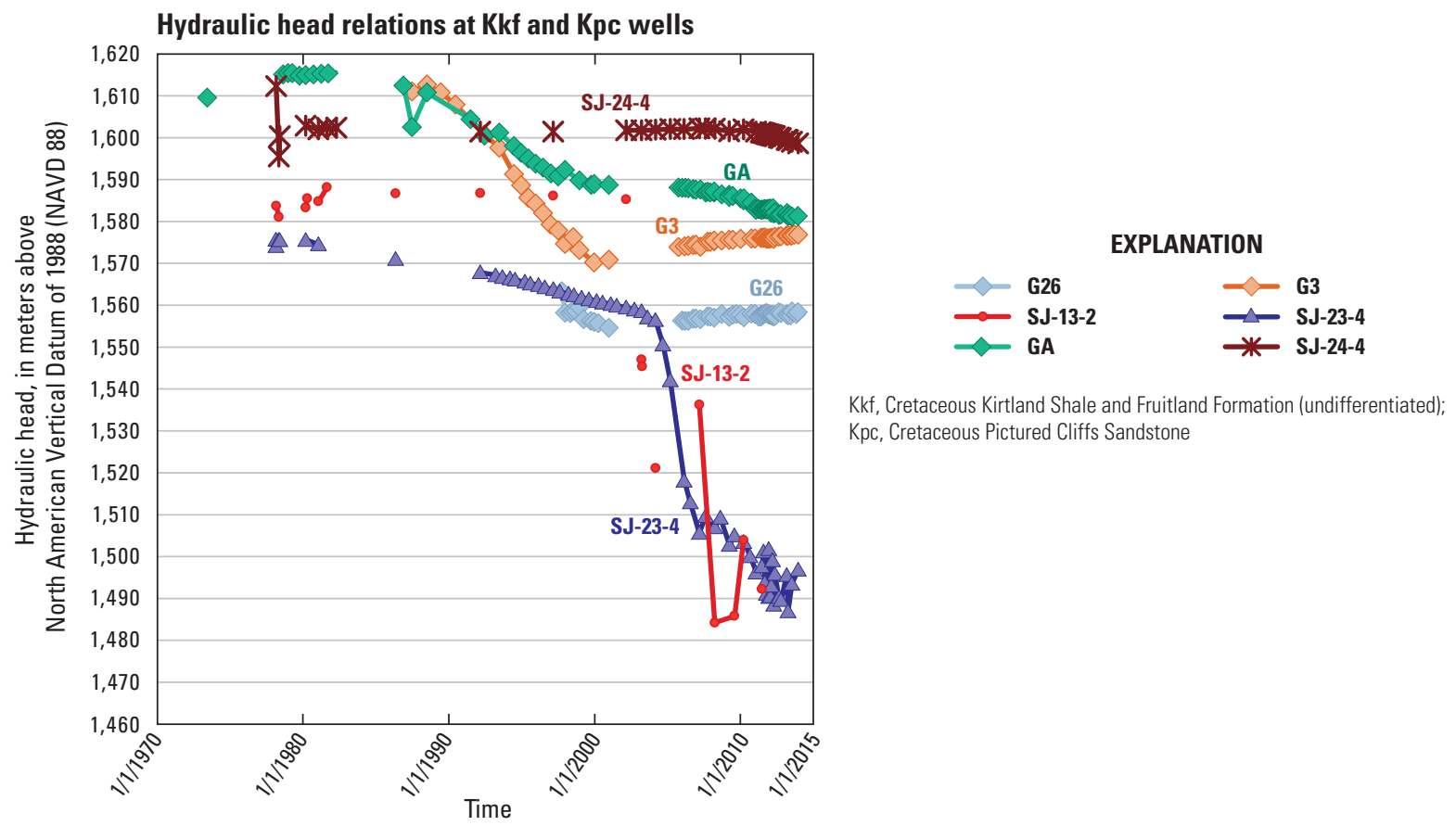

Figure 4. Hydraulic-head relations at long-term period of record Kkf and Kpc wells, San Juan County, New Mexico. 


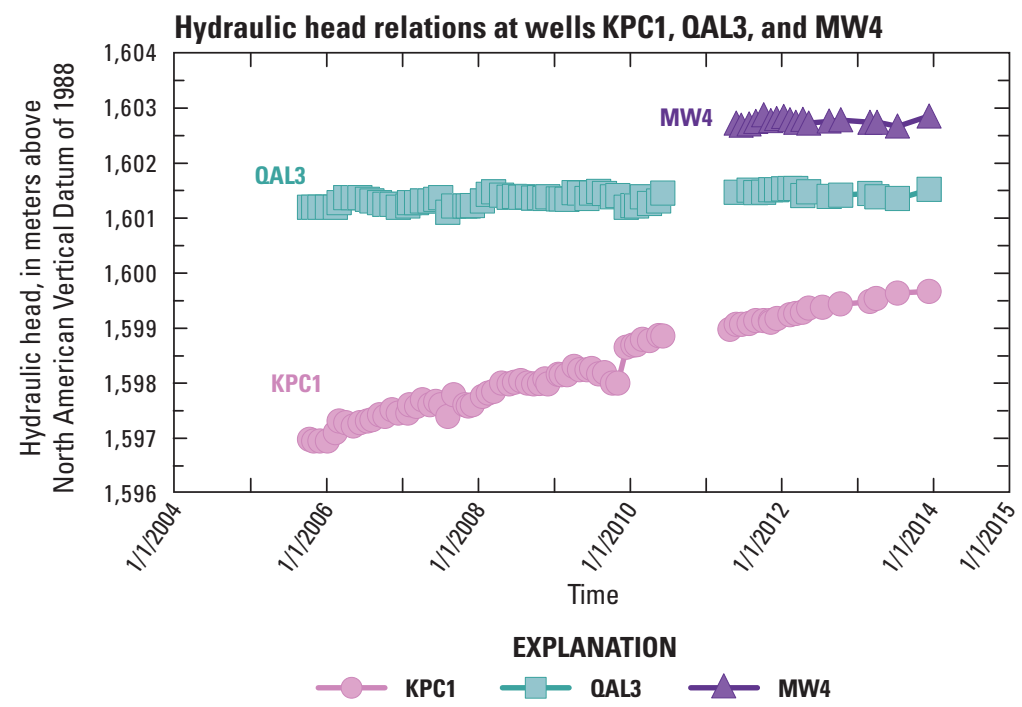

Figure 5. Hydraulic-head relations at wells KPC1, QAL3, and MW4, San Juan County, New Mexico.

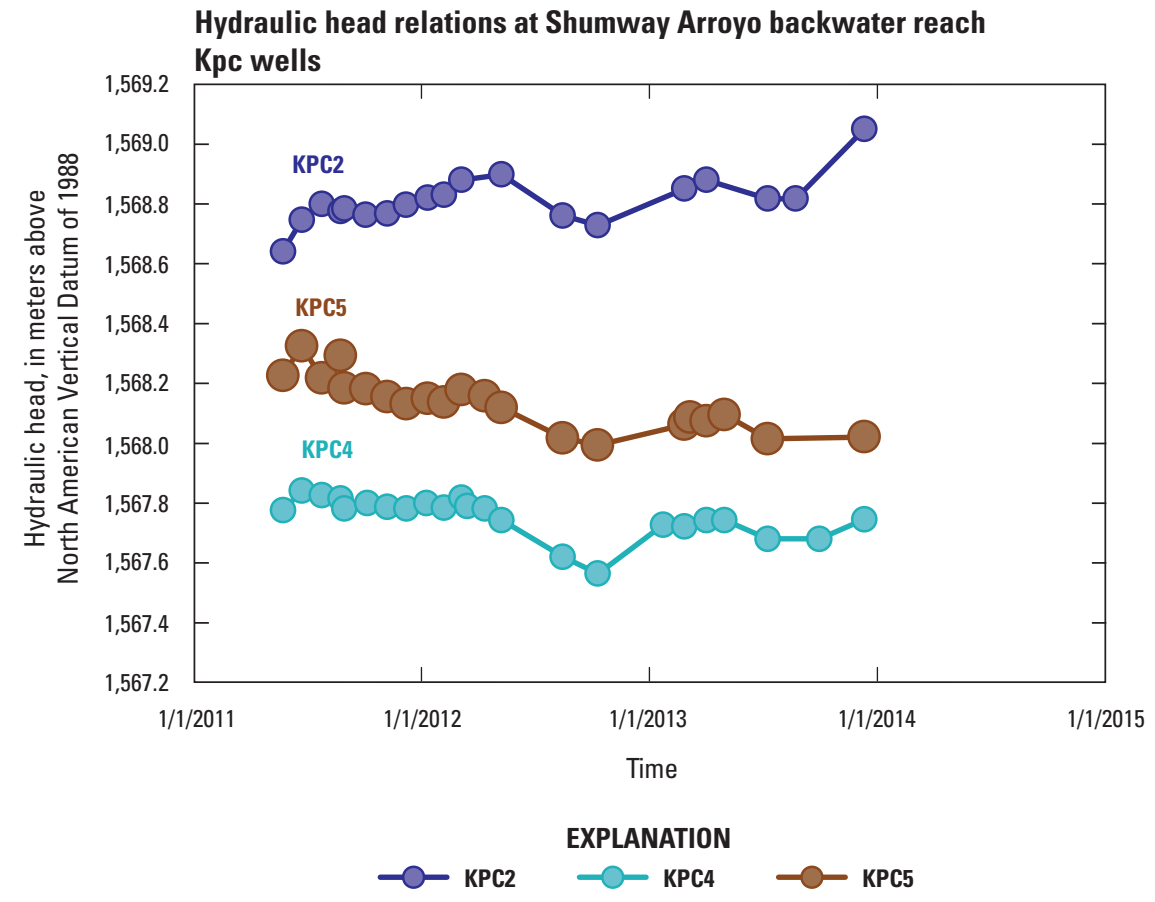

Kpc, Cretaceous Pictured Cliffs Sandstone

Figure 6. Hydraulic-head relations at Shumway Arroyo backwater reach Kpc wells, San Juan County, New Mexico. 


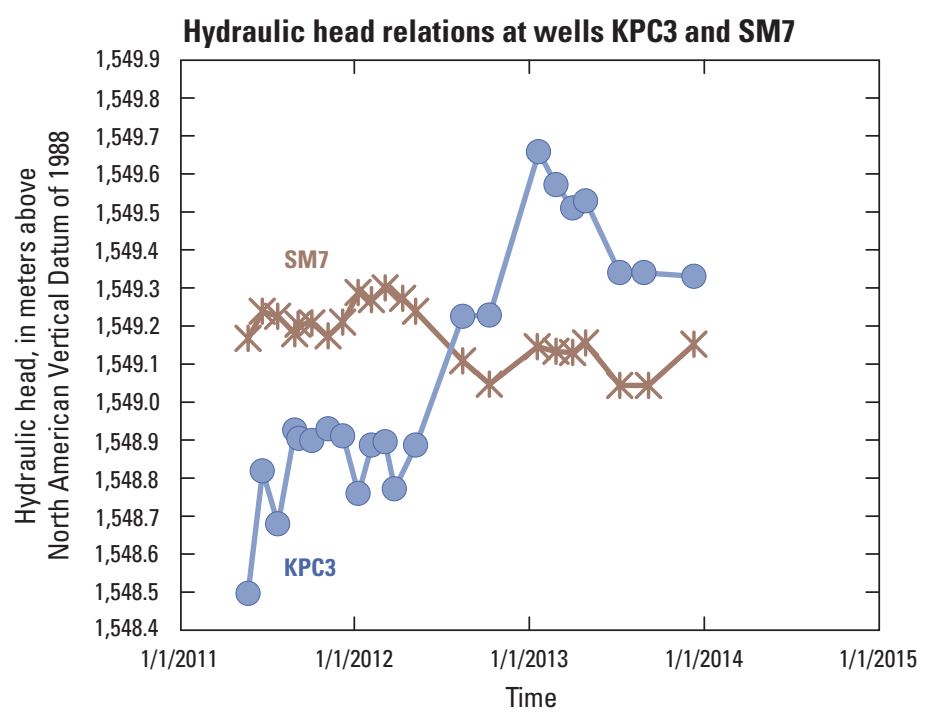

EXPLANATION

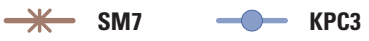

Figure 7. Hydraulic-head relations at wells KPC3 and SM7, San Juan County, New Mexico.

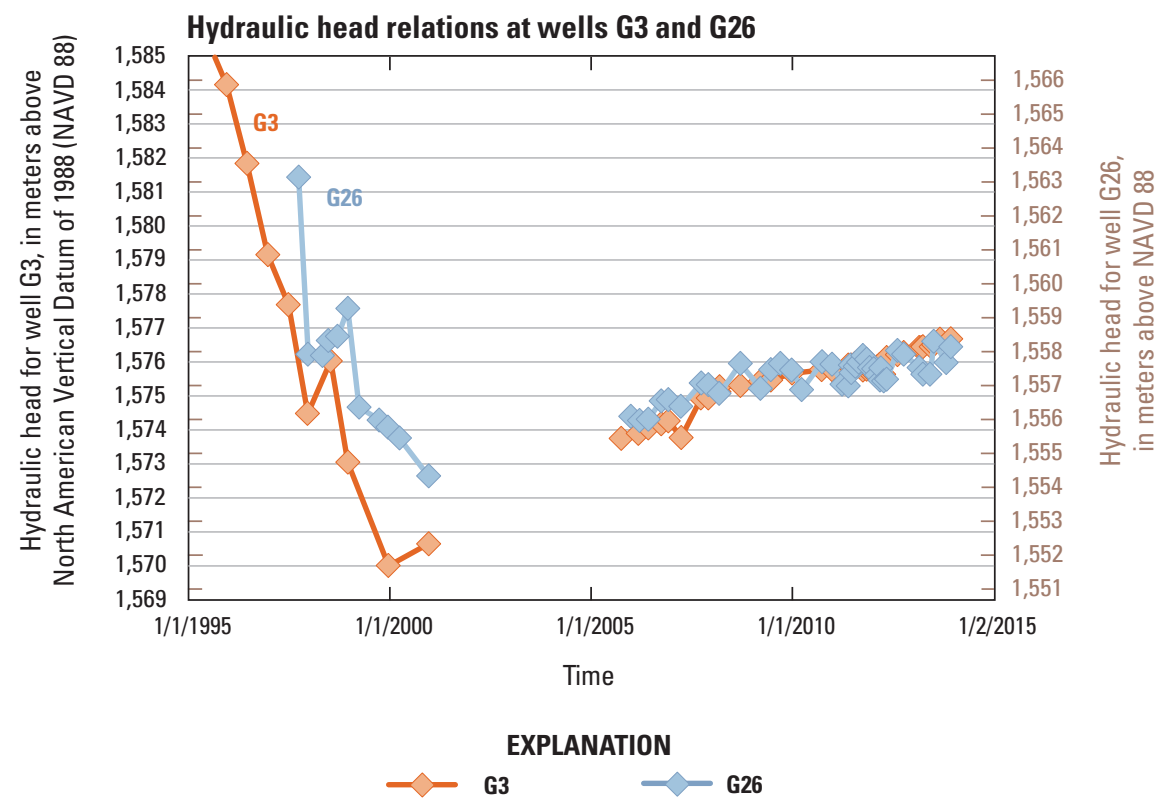

Figure 8. Hydraulic-head relations at wells G3 and G26, San Juan County, New Mexico. 


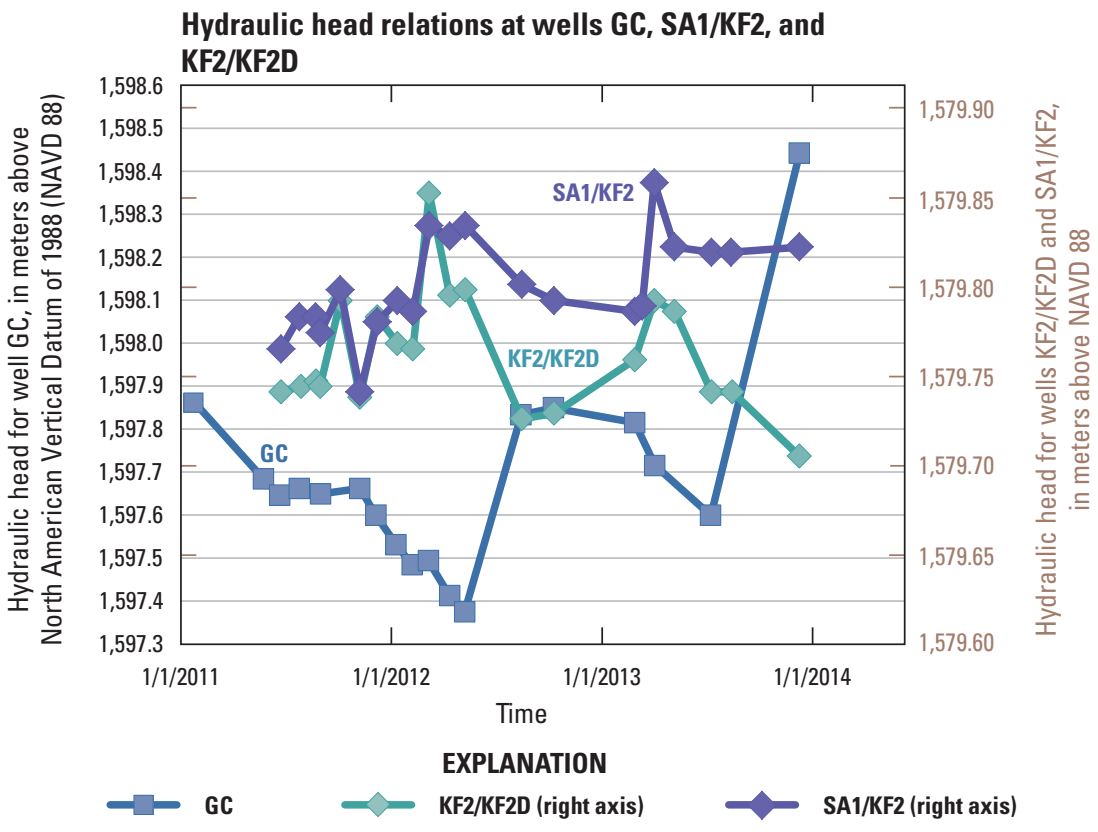

Note: Vertical axes at different scales

Figure 9. Hydraulic-head relations at wells GC, SA1/KF2, and KF2/KF2D, San Juan County, New Mexico.

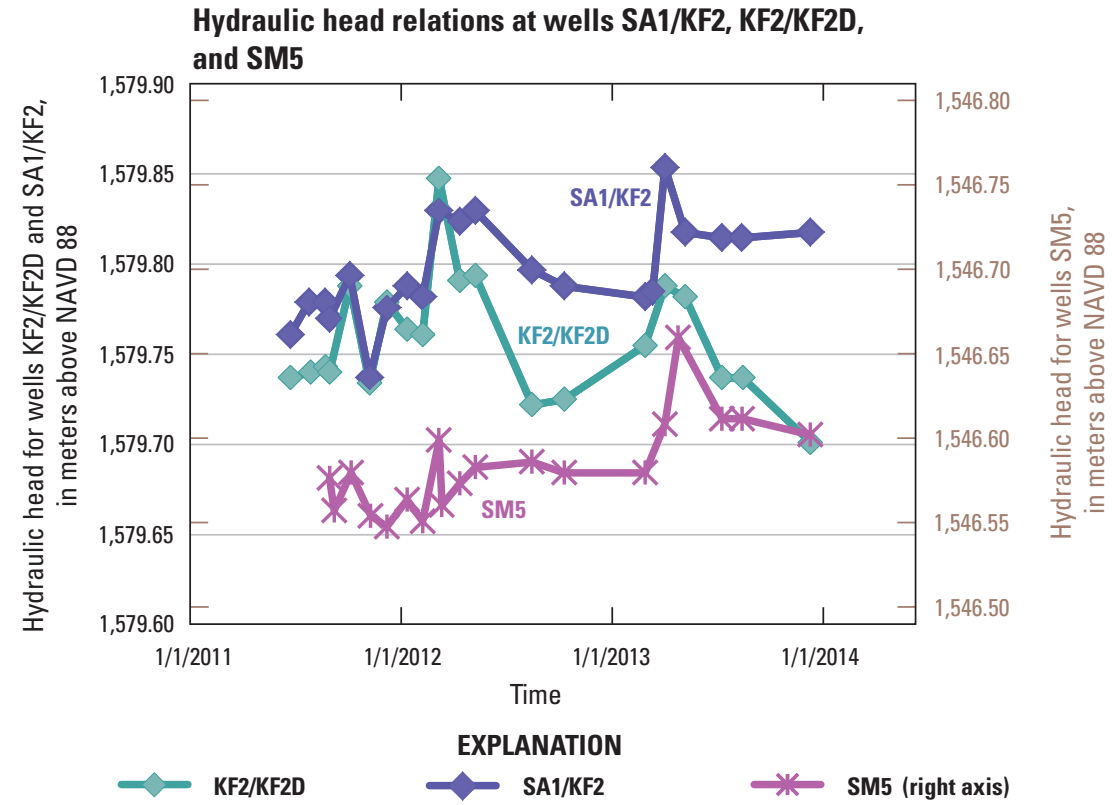

Figure 10. Hydraulic-head relations at wells SA1/KF2, KF2/KF2D, and SM5, San Juan County, New Mexico. 


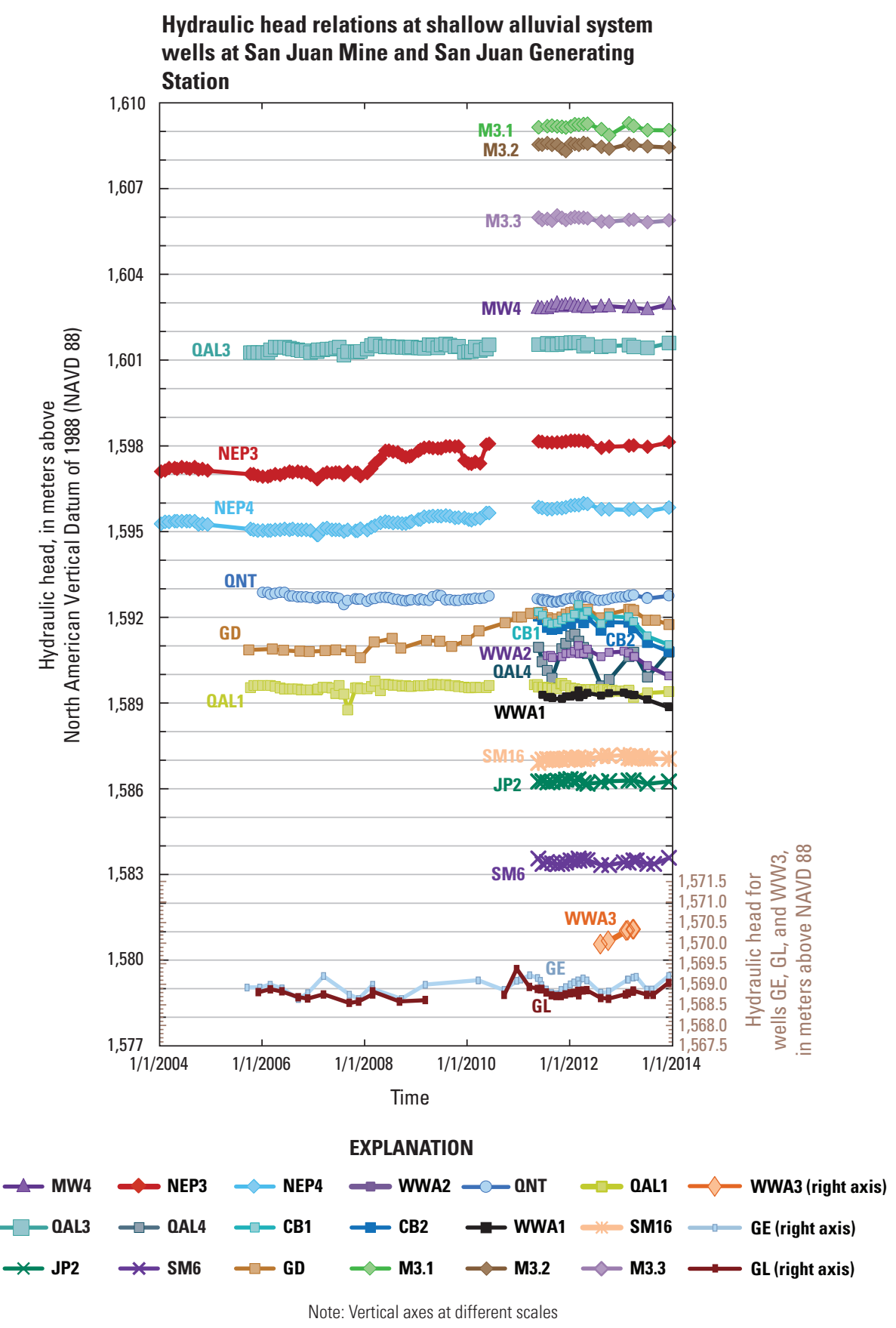

Figure 11. Hydraulic-head relations at representative shallow alluvial system wells at San Juan Mine and San Juan Generating Station, San Juan County, New Mexico. 


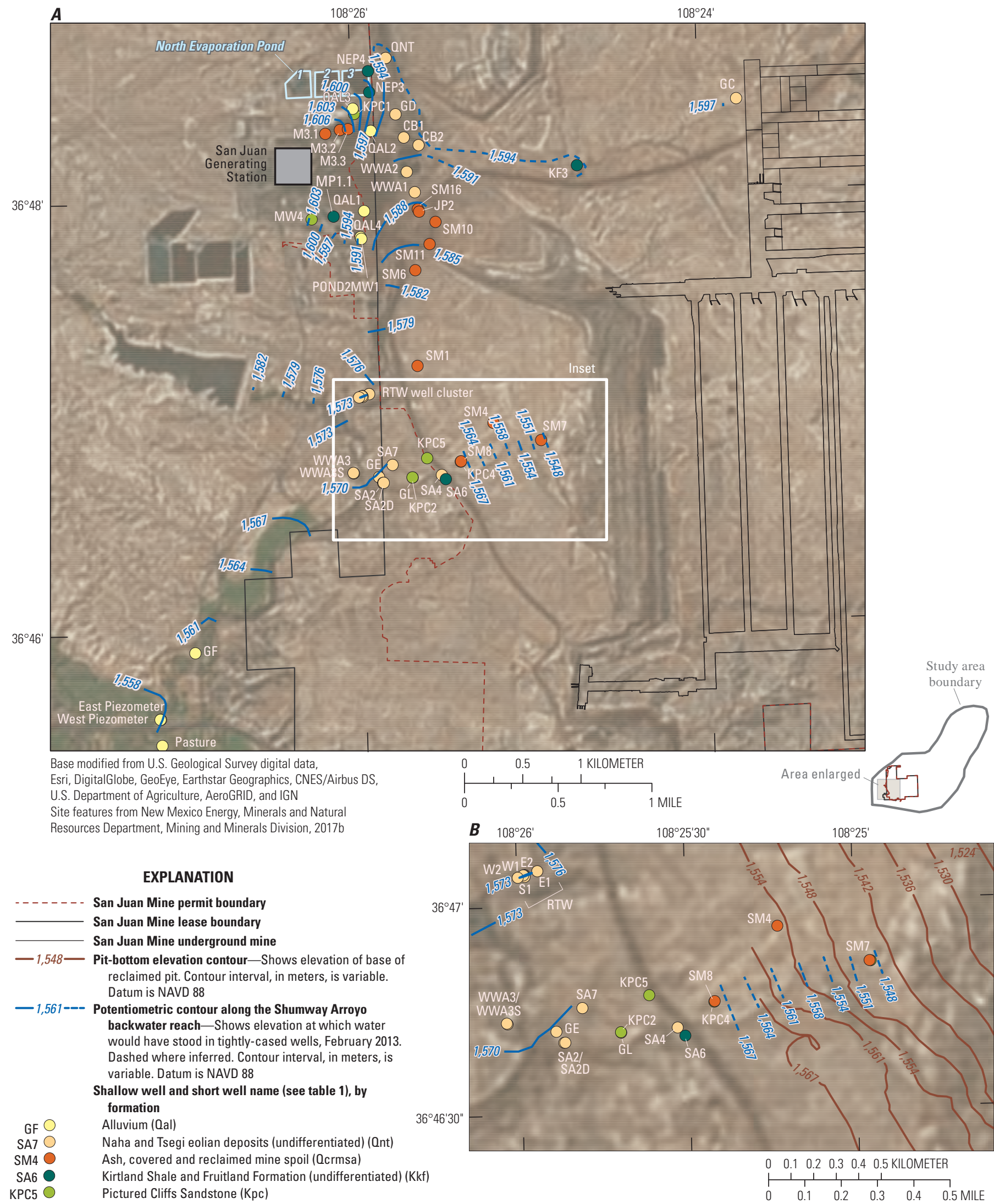

Figure 12. Potentiometric-surface contours of the San Juan Mine shallow alluvial system, February 2013, San Juan County, New Mexico. 
Table 3. Hydraulic properties of water-bearing units in the vicinity of the San Juan Mine, San Juan County, New Mexico.

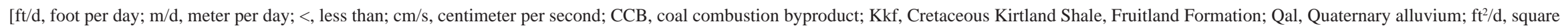
foot per day; Qnt, Naha and Tsegi alluvium deposits; H, horizontal; V, vertical; >, greater than; Toa, Tertiary Ojo Alamo Sandstone; Kta, Tertiary Animas Formation; Tn, Tertiary Nacimiento Formation;

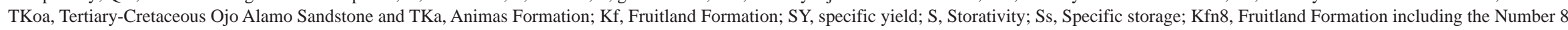
coal seam; Kpc, Cretaceous Pictured Cliffs Sandstone; Kls, Cretaceous Lewis Shale; Kch, Cretaceous Cliff House Sandstone; m, meter; NAD 83, North American Datum of 1983; NAVD 88, North American

Vertical Datum of 1988; S: storativity, water volume released from or added to storage of a confined aquifer per unit surface area per unit decline of hydraulic head over saturated aquifer thickness. Ss: specific

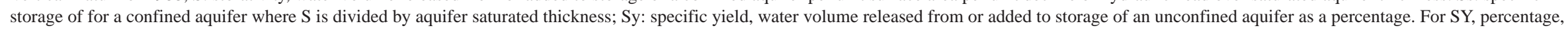
dimensionless; for S, per foot of saturated aquifer thickness; for Ss, dimensionless; R, row; C, column; L, layer]

\begin{tabular}{|c|c|c|c|c|c|c|c|c|c|c|}
\hline \multirow{3}{*}{$\begin{array}{l}\text { Material/ } \\
\text { formation }\end{array}$} & \multicolumn{5}{|c|}{ Hydraulic conductivity estimates } & \multirow{3}{*}{$\begin{array}{c}\text { Saturated } \\
\text { aquifer } \\
\text { thickness (b) } \\
\text { (feet) }\end{array}$} & \multirow{3}{*}{$\begin{array}{l}\text { Storage } \\
\text { value }\end{array}$} & \multirow{3}{*}{$\begin{array}{c}\text { Storage } \\
\text { coefficient } \\
\text { type }\end{array}$} & \multirow{3}{*}{$\begin{array}{l}\text { Porosity } \\
\text { (percent) }\end{array}$} & \multirow{3}{*}{ Source } \\
\hline & \multicolumn{2}{|c|}{$\mathrm{ft} / \mathrm{d}$} & \multicolumn{2}{|c|}{$\mathrm{m} / \mathrm{d}$} & \multirow[b]{2}{*}{ Notes } & & & & & \\
\hline & Horizontal & Vertical & Horizontal & Vertical & & & & & & \\
\hline \multirow[t]{3}{*}{$\begin{array}{l}\text { Top soil } \\
\text { mine spoil }\end{array}$} & $2.41 \times 10^{-2}$ & $2.41 \times 10^{-2}$ & $7.344 \times 10^{-3}$ & $7.344 \times 10^{-3}$ & $\begin{array}{l}<8.5 \times 10^{-6} \mathrm{~cm} / \mathrm{s} ; \\
\text { weathers to smectite } \\
\text { (swelling clay) }\end{array}$ & & & & & $\begin{array}{l}\text { Thomson and others } \\
\text { (2012) }\end{array}$ \\
\hline & & & $8.64 \times 10^{-6}$ & $8.64 \times 10^{-6}$ & $<10^{-8} \mathrm{~cm} / \mathrm{s}$ & & & & & $\begin{array}{l}\text { Luther and others } \\
\text { (2005) }\end{array}$ \\
\hline & & & & & & & & & 40 & $\begin{array}{l}\text { Metric Corporation } \\
(1990)\end{array}$ \\
\hline \multirow[t]{3}{*}{ CCB ash } & 0.283 & & 0.086 & & $1 \times 10^{-4} \mathrm{~cm} / \mathrm{s}$ for fly ash & & & & 44.7 & $\begin{array}{l}\text { Thomson and } \\
\text { others (2012) }\end{array}$ \\
\hline & 14.173 & & 4.320 & & $\begin{array}{l}5 \times 10^{-3} \mathrm{~cm} / \mathrm{s} \text { for } \\
\text { bottom ash }\end{array}$ & & & & & \\
\hline & $6.52 \times 10^{-4}$ & & $1.99 \times 10^{-4}$ & & $\begin{array}{l}2.3 \times 10^{-7} \mathrm{~cm} / \mathrm{s}, \\
\text { undifferentiated ash }\end{array}$ & & & & & $\begin{array}{l}\text { Luther and others } \\
\text { (2005) }\end{array}$ \\
\hline $\begin{array}{l}\text { Underground } \\
\text { subsided zone } \\
\text { in Kkf (gob) }\end{array}$ & & & & & & & 30 & SY & & $\begin{array}{l}\text { Mining and Minerals } \\
\text { Division (2017b) }\end{array}$ \\
\hline \multicolumn{11}{|l|}{$\overline{\text { Qal }}$} \\
\hline $\begin{array}{l}\text { (valley fill of } \\
\text { perennially } \\
\text { flowing } \\
\text { rivers) }\end{array}$ & $170-400$ & & $50-125$ & & $17,000-40,000 \mathrm{ft}^{2} / \mathrm{d}$ & $40-100$ & & & & $\begin{array}{l}\text { Stone and others } \\
\text { (1983) }\end{array}$ \\
\hline $\begin{array}{l}\text { San Juan River } \\
\text { Qal }\end{array}$ & 30 & & 9.144 & & & & & & & $\begin{array}{l}\text { Mining and Minerals } \\
\text { Division (2017b) }\end{array}$ \\
\hline \multirow[t]{2}{*}{$\begin{array}{l}\text { Qal } \\
\text { (ephemeral } \\
\text { stream } \\
\text { channels) }\end{array}$} & $<10-25$ & & $<3.05-7.62$ & & $\begin{array}{l}\text { Transmissivity }<1,000 \\
\mathrm{ft}^{2} / \mathrm{d} \text { in ephemeral } \\
\text { stream channels, } \\
\text { depends on } \\
\text { thickness }\end{array}$ & $40-100$ & & & & $\begin{array}{l}\text { Stone and others } \\
\text { (1983) }\end{array}$ \\
\hline & 14.5 & & 4.406 & & & & & & & $\begin{array}{l}\text { Mining and } \\
\text { Minerals Division } \\
\text { (2017b) }\end{array}$ \\
\hline \multirow{2}{*}{$\begin{array}{l}\text { Qnt } \\
\qquad \text { (assumed to } \\
\text { contain Qal) }\end{array}$} & 14.5 & & 4.406 & 0.0441 & $\begin{array}{l}\text { Horizontal: } \\
\quad 5.1 \times 10^{-3} \mathrm{~cm} / \mathrm{s} ; \mathrm{H}: \mathrm{V} \\
>=100: 1\end{array}$ & $10-30$ & & & & $\begin{array}{l}\text { Metric Corporation } \\
\text { (2007) }\end{array}$ \\
\hline & & & & & & & & & 35 & $\begin{array}{l}\text { Metric Corporation } \\
\text { (2003) } \\
\text { Phillips (1982) }\end{array}$ \\
\hline
\end{tabular}


Table 3. Hydraulic properties of water-bearing units in the vicinity of the San Juan Mine, San Juan County, New Mexico.-Continued

[ft/d, foot per day; m/d, meter per day; <, less than; cm/s, centimeter per second; CCB, coal combustion byproduct; Kkf, Cretaceous Kirtland Shale, Fruitland Formation; Qal, Quaternary alluvium; ft²/d, square foot per day; Qnt, Naha and Tsegi alluvium deposits; H, horizontal; V, vertical; >, greater than; Toa, Tertiary Ojo Alamo Sandstone; Kta, Tertiary Animas Formation; Tn, Tertiary Nacimiento Formation;

TKoa, Tertiary-Cretaceous Ojo Alamo Sandstone and TKa, Animas Formation; Kf, Fruitland Formation; SY, specific yield; S, Storativity; Ss, Specific storage; Kfn8, Fruitland Formation including the

Number 8 coal seam; Kpc, Cretaceous Pictured Cliffs Sandstone; Kls, Cretaceous Lewis Shale; Kch, Cretaceous Cliff House Sandstone; m, meter; NAD 83, North American Datum of 1983; NAVD 88, North American Vertical Datum of 1988; S: storativity, water volume released from or added to storage of a confined aquifer per unit surface area per unit decline of hydraulic head over saturated aquifer thickness.

Ss: specific storage of for a confined aquifer where $\mathrm{S}$ is divided by aquifer saturated thickness; Sy: specific yield, water volume released from or added to storage of an unconfined aquifer as a percentage. For

SY, percentage, dimensionless; for S, per foot of saturated aquifer thickness; for Ss, dimensionless; R, row; C, column; L, layer]

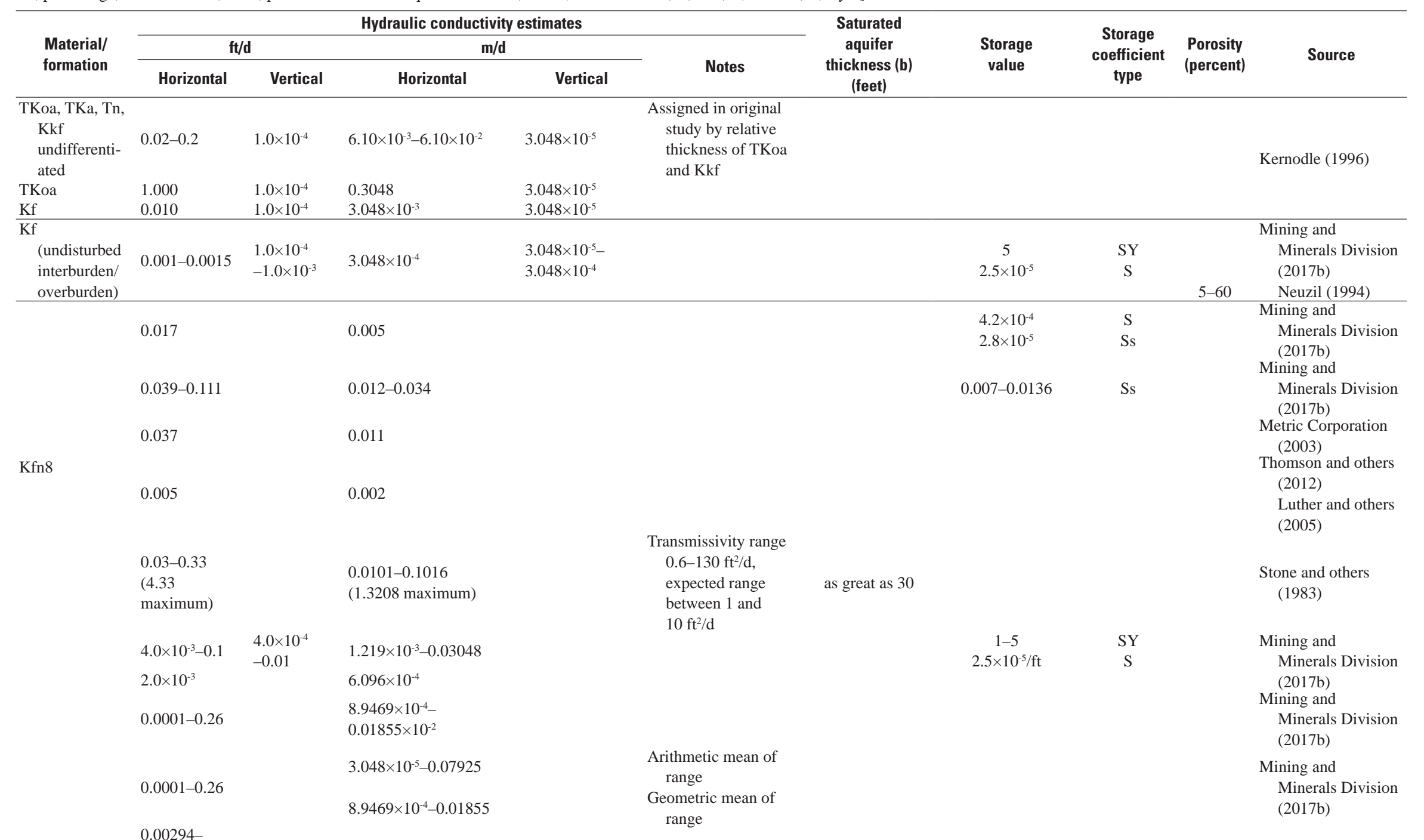

0.03561 
Table 3. Hydraulic properties of water-bearing units in the vicinity of the San Juan Mine, San Juan County, New Mexico.-Continued

[ft/d, foot per day; m/d, meter per day; <, less than; cm/s, centimeter per second; CCB, coal combustion byproduct; Kkf, Cretaceous Kirtland Shale, Fruitland Formation; Qal, Quaternary alluvium; ft²/d, square foot per day; Qnt, Naha and Tsegi alluvium deposits; H, horizontal; V, vertical; >, greater than; Toa, Tertiary Ojo Alamo Sandstone; Kta, Tertiary Animas Formation; Tn, Tertiary Nacimiento Formation;

TKoa, Tertiary-Cretaceous Ojo Alamo Sandstone and TKa, Animas Formation; Kf, Fruitland Formation; SY, specific yield; S, Storativity; Ss, Specific storage; Kfn8, Fruitland Formation including the

Number 8 coal seam; Kpc, Cretaceous Pictured Cliffs Sandstone; Kls, Cretaceous Lewis Shale; Kch, Cretaceous Cliff House Sandstone; m, meter; NAD 83, North American Datum of 1983; NAVD 88, North

American Vertical Datum of 1988; S: storativity, water volume released from or added to storage of a confined aquifer per unit surface area per unit decline of hydraulic head over saturated aquifer thickness.

Ss: specific storage of for a confined aquifer where $\mathrm{S}$ is divided by aquifer saturated thickness; Sy: specific yield, water volume released from or added to storage of an unconfined aquifer as a percentage. For

SY, percentage, dimensionless; for S, per foot of saturated aquifer thickness; for Ss, dimensionless; R, row; C, column; L, layer]

\begin{tabular}{|c|c|c|c|c|c|c|c|c|c|c|}
\hline \multirow{3}{*}{$\begin{array}{l}\text { Material/ } \\
\text { formation }\end{array}$} & \multicolumn{5}{|c|}{ Hydraulic conductivity estimates } & \multirow{3}{*}{$\begin{array}{c}\text { Saturated } \\
\text { aquifer } \\
\text { thickness (b) } \\
\text { (feet) }\end{array}$} & \multirow{3}{*}{$\begin{array}{l}\text { Storage } \\
\text { value }\end{array}$} & \multirow{3}{*}{$\begin{array}{c}\text { Storage } \\
\text { coefficient } \\
\text { type }\end{array}$} & \multirow{3}{*}{$\begin{array}{c}\text { Porosity } \\
\text { (percent) }\end{array}$} & \multirow{3}{*}{ Source } \\
\hline & \multicolumn{2}{|c|}{$\mathrm{ft} / \mathrm{d}$} & \multicolumn{2}{|c|}{$\mathrm{m} / \mathrm{d}$} & \multirow[b]{2}{*}{ Notes } & & & & & \\
\hline & Horizontal & Vertical & Horizontal & Vertical & & & & & & \\
\hline & 0.051 & & 0.016 & & $1.8 \times 10^{-5} \mathrm{~cm} / \mathrm{s}$ & & & & & $\begin{array}{l}\text { Metric Corporation } \\
\text { (2007) }\end{array}$ \\
\hline & 0.071 & & 0.022 & & $\begin{array}{l}\text { 0.002-811 milli- } \\
\text { Darcys, } \\
\text { logarithmic mean } \\
26 \text { milliDarcys }^{\mathrm{a}}\end{array}$ & & & & & Oldaker (1991) \\
\hline & & & & & $\mathrm{H}: \mathrm{V}=17: 1$ & & & & & $\begin{array}{l}\text { Chen and others } \\
\text { (2012) }\end{array}$ \\
\hline $\begin{array}{l}\text { Local shale } \\
\text { underlying } \\
\text { Kfn8 }\end{array}$ & $4.0 \times 10^{-3}$ & $4.0 \times 10^{-4}$ & $1.219 \times 10^{-3}$ & $1.219 \times 10^{-5}$ & $\begin{array}{l}\text { when represented } \\
\text { as unique layer }\end{array}$ & & 0.05 & SY & & $\begin{array}{l}\text { Mining and } \\
\text { Minerals Division } \\
\text { (2017b) }\end{array}$ \\
\hline & $7.0 \times 10^{-3}$ & $7.0 \times 10^{-5}$ & $2.1336 \times 10^{-3}$ & $2.1336 \times 10^{-5}$ & & & & & & Kernodle (1996) \\
\hline & $7.0 \times 10^{-3}$ & & $2.1336 \times 10^{-3}$ & & & & & & & $\begin{array}{l}\text { Stone and others } \\
\text { (1983) }\end{array}$ \\
\hline & $1.055 \times 10^{-2}$ & & $3.214 \times 10^{-3}$ & & $\begin{array}{l}\text { Transmissivity of } 1.16 \\
\mathrm{ft}^{2} / \mathrm{d}\end{array}$ & 110 & & & & $\begin{array}{l}\text { Mining and } \\
\text { Minerals Division } \\
\text { (2017b) }\end{array}$ \\
\hline & $0.011-0.015$ & & $3.353 \times 10^{-3}-4.572 \times 10^{-3}$ & & & & & & & $\begin{array}{l}\text { Mining and } \\
\text { Minerals Division } \\
\text { (2017b) }\end{array}$ \\
\hline Крс & $8.085 \times 10^{-3}$ & & $2.464 \times 10^{-3}$ & & 2.96 milliDarcys & & & & 18.1 & $\begin{array}{l}\text { Reneau and Harris } \\
\text { (1957) }\end{array}$ \\
\hline & & & & & & & & & & Mining and \\
\hline & $1.5 \times 10^{-2}$ & $1.5 \times 10^{-3}$ & & & & & 5 & SY & & $\begin{array}{l}\text { Minerals Division } \\
\text { (2017b) }\end{array}$ \\
\hline & $3.0 \times 10^{-2}$ & & $9.144 \times 10^{-3}$ & & & & & & & $\begin{array}{l}\text { Luther and others } \\
\text { (2005) }\end{array}$ \\
\hline & 0.011 & & $3.37 \times 10^{-3}$ & & $3.9 \times 10^{-6} \mathrm{~cm} / \mathrm{s}$ & & & & & $\begin{array}{l}\text { Metric Corporation } \\
\text { (2007) }\end{array}$ \\
\hline & 328 & 33 & 100 & 10 & In fractures & & & & & $\begin{array}{l}\text { Cox and others } \\
\text { (2001) }\end{array}$ \\
\hline
\end{tabular}


Table 3. Hydraulic properties of water-bearing units in the vicinity of the San Juan Mine, San Juan County, New Mexico.-Continued

[ft/d, foot per day; m/d, meter per day; <, less than; cm/s, centimeter per second; CCB, coal combustion byproduct; Kkf, Cretaceous Kirtland Shale, Fruitland Formation; Qal, Quaternary alluvium; ft²/d, square foot per day; Qnt, Naha and Tsegi alluvium deposits; H, horizontal; V, vertical; >, greater than; Toa, Tertiary Ojo Alamo Sandstone; Kta, Tertiary Animas Formation; Tn, Tertiary Nacimiento Formation;

TKoa, Tertiary-Cretaceous Ojo Alamo Sandstone and TKa, Animas Formation; Kf, Fruitland Formation; SY, specific yield; S, Storativity; Ss, Specific storage; Kfn8, Fruitland Formation including the

Number 8 coal seam; Kpc, Cretaceous Pictured Cliffs Sandstone; Kls, Cretaceous Lewis Shale; Kch, Cretaceous Cliff House Sandstone; m, meter; NAD 83, North American Datum of 1983; NAVD 88, North American Vertical Datum of 1988; S: storativity, water volume released from or added to storage of a confined aquifer per unit surface area per unit decline of hydraulic head over saturated aquifer thickness.

Ss: specific storage of for a confined aquifer where $\mathrm{S}$ is divided by aquifer saturated thickness; Sy: specific yield, water volume released from or added to storage of an unconfined aquifer as a percentage. For

SY, percentage, dimensionless; for S, per foot of saturated aquifer thickness; for Ss, dimensionless; R, row; C, column; L, layer]

\begin{tabular}{|c|c|c|c|c|c|c|c|c|c|c|}
\hline \multirow{3}{*}{$\begin{array}{l}\text { Material/ } \\
\text { formation }\end{array}$} & \multicolumn{5}{|c|}{ Hydraulic conductivity estimates } & \multirow{3}{*}{$\begin{array}{c}\text { Saturated } \\
\text { aquifer } \\
\text { thickness (b) } \\
\text { (feet) }\end{array}$} & \multirow{3}{*}{$\begin{array}{l}\text { Storage } \\
\text { value }\end{array}$} & \multirow{3}{*}{$\begin{array}{l}\text { Storage } \\
\text { coefficient } \\
\text { type }\end{array}$} & \multirow{3}{*}{$\begin{array}{l}\text { Porosity } \\
\text { (percent) }\end{array}$} & \multirow{3}{*}{ Source } \\
\hline & \multicolumn{2}{|c|}{$\mathrm{ft} / \mathrm{d}$} & \multicolumn{2}{|c|}{$\mathrm{m} / \mathrm{d}$} & \multirow[b]{2}{*}{ Notes } & & & & & \\
\hline & Horizontal & Vertical & Horizontal & Vertical & & & & & & \\
\hline \multirow{9}{*}{ Kls } & $5.0 \times 10^{-5}$ & $5.0 \times 10^{-6}$ & $1.52 \times 10^{-5}$ & $1.52 \times 10^{-6}$ & & & & & & Kernodle (1996) \\
\hline & $5.8 \times 10^{-7}$ & $5.8 \times 10^{-11}$ & $1.8 \times 10^{-7}$ & $1.8 \times 10^{-11}$ & & & & & & $\begin{array}{l}\text { Frenzel and Lyford } \\
\text { (1982) }\end{array}$ \\
\hline & $2.73 \times 10^{-5}$ & & $8.32 \times 10^{-6}$ & & $\begin{array}{l}0.01 \text { milliDarcys } \\
(\text { matrix })^{\mathrm{a}}\end{array}$ & & & & $\begin{array}{c}2-8 \\
2.9-5.44\end{array}$ & Dubiel (2013) \\
\hline & $\begin{array}{l}2.73 \times 10^{-} \\
{ }^{7}-2.73 \times 10^{-11}\end{array}$ & & $\begin{array}{l}8.321 \times 10^{-8}- \\
8.321 \times 10^{-12}\end{array}$ & & $\begin{array}{l}10^{-4} \text { to } 10^{-8} \\
\text { milliDarcys }^{\mathrm{a}}\end{array}$ & & & & & $\begin{array}{l}\text { Lewis and others } \\
\text { (2004) }\end{array}$ \\
\hline & $\begin{array}{l}2.84 \times 10^{-4}- \\
2.84 \times 10^{-7}\end{array}$ & & $\begin{array}{l}8.64 \times 10^{-5}- \\
8.64 \times 10^{-8}\end{array}$ & & $\begin{array}{l}\text { converted from } 10^{-9}- \\
10^{-12} \mathrm{~m} / \mathrm{s}\end{array}$ & & & & $5-60$ & Neuzil (1994) \\
\hline & & $\begin{array}{l}8.64 \times 10^{-7} \\
-8.64 \times \\
10^{-8} \\
8.64 \times \\
10^{-5}-8.64 \\
\times 10^{-8} \\
\text { (absolute } \\
\text { range from } \\
\text { sensitivity } \\
\text { analysis) }\end{array}$ & & $\begin{array}{l}2.63 \times 10^{-7}-2.63 \\
\times 10^{-8} \\
2.63 \times 10^{-5}- \\
2.63 \times 10^{-8} \\
\text { (absolute range } \\
\text { from sensitivity } \\
\text { analysis) }\end{array}$ & $\begin{array}{l}1 \times 10^{-11} \text { to } \\
1 \times 10^{-12} \mathrm{ft} / \mathrm{s} \text {, } \\
\text { sensitivity analysis } \\
\text { allows for x10- } \\
\text { x100 greater }\end{array}$ & & & & & $\begin{array}{l}\text { Frenzel and Lyford } \\
\text { (1982) }\end{array}$ \\
\hline & & & & & & & & & 3.5 & $\begin{array}{l}\text { U.S. Energy } \\
\text { Information } \\
\text { Administration } \\
\text { (2011) }\end{array}$ \\
\hline & $2.84 \times 10^{-6}$ & & $8.64 \times 10^{-7}$ & & $1 \times 10^{-9} \mathrm{~cm} / \mathrm{s}$ & & & & & $\begin{array}{l}\text { Metric Corporation } \\
\text { (2007) }\end{array}$ \\
\hline & & $2.84 \times 10^{-5}$ & & $8.66 \times 10^{-6}$ & $1 \times 10^{-11} \mathrm{~cm} / \mathrm{s}$ & & & & & \\
\hline \multirow{4}{*}{ Kch } & $0.0067-0.2000$ & $6.7 \times 10^{-3}-0.2$ & $0.002-0.061$ & & from $\mathrm{T}=2-60 \mathrm{ft}^{2} / \mathrm{d}$ & 300 & & & & $\begin{array}{l}\text { Stone and others } \\
\text { (1983) }\end{array}$ \\
\hline & 0.0015 & & 0.00045 & & $\begin{array}{l}\text { average value } \\
\text { reported to be } \\
0.54 \text { milliDarcys }^{\mathrm{a}}\end{array}$ & & & & $\begin{array}{c}\text { range: } \\
3-17.2 \\
\text { average: } \\
10.3\end{array}$ & $\begin{array}{l}\text { Reneau and Harris } \\
\text { (1957) }\end{array}$ \\
\hline & 0.1000 & 0.0010 & 0.0305 & $3.0408 \times 10^{-4}$ & & & & & & Kernodle (1996) \\
\hline & $4 \times 10^{-4}-8 \times 10^{-4}$ & & $1.3 \times 10^{-4}-2.5 \times 10^{-4}$ & & $0.15-0.3$ milliDarcys $^{\mathrm{a}}$ & & & & $\begin{array}{c}\text { range: } \\
\text { 8-14 } \\
\text { range: 4-6 }\end{array}$ & $\begin{array}{l}\text { Dubiel (2013) } \\
\text { Hoppe (1978) }\end{array}$ \\
\hline
\end{tabular}


[ft/d, foot per day; m/d, meter per day; <, less than; cm/s, centimeter per second; CCB, coal combustion byproduct; Kkf, Cretaceous Kirtland Shale,Fruitland Formation; Qal, Quaternary alluvium; ft²/d, square foot per day; Qnt, Naha and Tsegi alluvium deposits; H, horizontal; V, vertical; >, greater than; Toa, Tertiary Ojo Alamo Sandstone; Kta, Tertiary Animas Formation Tn, Tertiary Nacimiento Formation;

TKoa, Tertiary-Cretaceous Ojo Alamo Sandstone and TKa, Animas Formation; Kf, Fruitland Formation; SY, specific yield; S,Storativity; Ss, Specific storage; Kfn8, Fruitland Formation including the Number 8 coal seam; Kpc, Cretaceous Pictured Cliffs Sandstone; Kls, Cretaceous Lewis Shale; Kch, Cretaceous Cliff House Sandstone; m, meter; NAD 83, North American Datum of 1983; NAVD 88, North American Vertical Datum of 1988; S: storativity, water volume released from or added to storage of a confined aquifer per unit surface area per unit decline of hydraulic head over saturated aquifer thickness. Ss: specific storage of for a confined aquifer where S is divided by aquifer saturated thickness; Sy: specific yield, water volume released from or added to storage of an unconfined aquifer as a percentage. For SY, percentage, dimensionless; for S, per foot of saturated aquifer thickness; for Ss, dimensionless; R, row; C, column; L, layer]

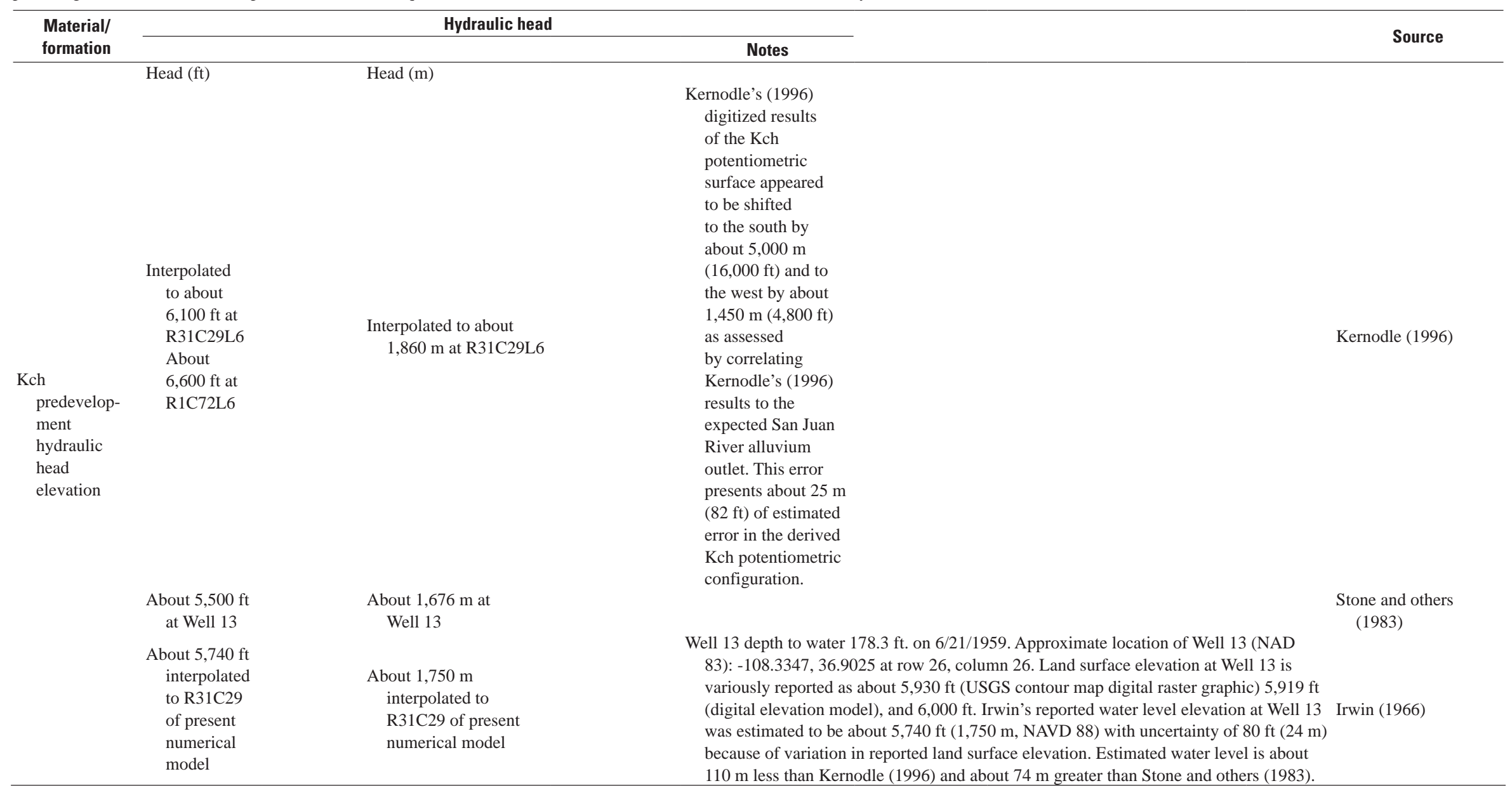

a Conversion to saturated hydraulic conductivity from permeability assumes water at 20 degrees Celsius. 
Table 4. Average concentrations of calcium, chloride, sodium, sulfate and dissolved solids for given date ranges for groundwater at or in the vicinity of the San Juan Mine, New Mexico.

[Site name, sites with correlated water levels found in table 1; MMD, New Mexico Mining and Minerals Division; SJGS, San Juan Generating Station; SJM, San Juan Mine, San Juan Coal Mine; mg/L, milligram per liter; --, not sampled]

\begin{tabular}{|c|c|c|c|c|c|c|c|c|c|c|}
\hline Source & Location & $\begin{array}{c}\text { Site } \\
\text { name }\end{array}$ & $\begin{array}{c}\text { Number } \\
\text { of } \\
\text { samples } \\
\text { in date } \\
\text { range }\end{array}$ & $\begin{array}{c}\text { From date } \\
\text { (mm/dd/yyyy) }\end{array}$ & $\begin{array}{c}\text { To date } \\
\text { (mm/dd/yyyy) }\end{array}$ & $\begin{array}{c}\text { Calcium } \\
\text { (mg/L) }\end{array}$ & $\begin{array}{c}\text { Chloride } \\
\text { (mg/L) }\end{array}$ & $\begin{array}{l}\text { Sodium } \\
\text { (mg/L) }\end{array}$ & $\begin{array}{l}\text { Sulfate } \\
\text { (mg/L) }\end{array}$ & $\begin{array}{l}\text { Dissolved } \\
\text { solids } \\
\text { (mg/L) }\end{array}$ \\
\hline MMD reporting & SJGS & KPC1 & 8 & 9/28/2011 & $10 / 3 / 2013$ & 35 & 386 & 1,703 & 1,438 & 4,714 \\
\hline MMD reporting & SJM & КPC2 & 11 & 9/13/2011 & $10 / 15 / 2013$ & 413 & 3,255 & 10,727 & 21,927 & 33,427 \\
\hline MMD reporting & SJM & КРC3 & 12 & 9/8/2011 & $12 / 23 / 2013$ & 32 & 1,629 & 3,076 & 4,158 & 8,626 \\
\hline MMD reporting & SJM & KPC4 & 10 & $8 / 25 / 2011$ & $12 / 18 / 2013$ & 222 & 4,270 & 9,208 & 16,600 & 28,900 \\
\hline MMD reporting & SJM & KPC5 & 11 & 8/25/2011 & $10 / 15 / 2013$ & 31 & 1,845 & 4,379 & 6,509 & 12,518 \\
\hline MMD reporting & SJM & SM5 & 16 & 9/8/2011 & $12 / 11 / 2013$ & 203 & 1,886 & 7,066 & 12,086 & 21,786 \\
\hline MMD reporting & SJM & SM6 & 15 & 8/25/2011 & $12 / 3 / 2013$ & 361 & 2,984 & 4,547 & 6,793 & 15,087 \\
\hline MMD reporting & SJM & SM7 & 9 & 9/7/2011 & $12 / 23 / 2013$ & 350 & 640 & 5,428 & 11,089 & 18,233 \\
\hline MMD reporting & SJM & SM16 & 11 & 9/7/2011 & 10/30/2013 & 174 & 2,999 & 5,588 & 7,530 & 17,218 \\
\hline MMD reporting & SJM & JP2 & 1 & 10/3/2012 & 10/3/2012 & 233 & 3,800 & 5,970 & 7,000 & 17,400 \\
\hline MMD reporting & SJM & WWA1 & 14 & $8 / 22 / 2011$ & 10/30/2013 & 265 & 279 & 886 & 2,530 & 4,513 \\
\hline MMD reporting & SJM & WWA2 & 12 & 8/22/2011 & $12 / 2 / 2013$ & 387 & 199 & 683 & 2,617 & 4,238 \\
\hline MMD reporting & SJM & SA1 & 2 & 1/0/1900 & $10 / 24 / 2013$ & 407 & 915 & 5,980 & 13,500 & 21,800 \\
\hline MMD reporting & SJM & SA2D & 4 & $8 / 22 / 2011$ & $4 / 24 / 2013$ & 375 & 5,325 & 11,575 & 19,500 & 34,150 \\
\hline MMD reporting & SJM & SA7 & 3 & 8/22/2011 & $10 / 17 / 2013$ & 347 & 5,600 & 11,600 & 18,333 & 34,467 \\
\hline MMD reporting & SJM & KF2 & 4 & 3/12/2013 & $10 / 22 / 2013$ & 384 & 1,053 & 5,650 & 13,750 & 19,300 \\
\hline MMD reporting & SJM & WWA3 & 4 & 9/12/2012 & 4/8/2013 & 404 & 1,150 & 2,933 & 7,425 & 12,475 \\
\hline PNM (as per NMED) & SJGS & CB1 & 3 & 8/14/2012 & 2/7/2013 & 428 & 236 & 901 & -- & 5,857 \\
\hline PNM (as per NMED) & SJGS & CB2 & 3 & $8 / 14 / 2012$ & 2/7/2013 & 250 & 443 & 1,390 & -- & 6,520 \\
\hline MMD reporting & SJM & G26 & 8 & 9/13/2011 & $12 / 18 / 2013$ & 19 & 86 & 1,680 & 2,463 & 4,896 \\
\hline MMD reporting & SJM & G3 & 11 & 9/15/2011 & 9/5/2013 & 3 & 347 & 1,109 & 317 & 2,740 \\
\hline MMD reporting & SJM & GA & 9 & 1/9/2012 & $12 / 17 / 2013$ & 3 & 1,478 & 2,561 & 1,202 & 6,621 \\
\hline MMD reporting & SJM & GD & 12 & $9 / 15 / 2011$ & $10 / 21 / 2013$ & 446 & 771 & 2,563 & 7,058 & 11,453 \\
\hline MMD reporting & SJM & GE & 12 & 9/13/2011 & $10 / 16 / 2013$ & 432 & 1,775 & 4,340 & 10,342 & 18,008 \\
\hline MMD reporting & SJM & GL & 13 & 9/13/2011 & $11 / 19 / 2013$ & 473 & 7,531 & 19,723 & 38,769 & 74,731 \\
\hline PNM (as per NMED) & SJGS & M3.1 & 3 & 8/14/2012 & 2/7/2013 & 330 & 107 & 412 & -- & 3,863 \\
\hline PNM (as per NMED) & SJGS & M3.2 & 3 & 8/14/2012 & 2/7/2013 & 453 & 170 & 816 & -- & 7,887 \\
\hline PNM (as per NMED) & SJGS & M3.3 & 3 & $8 / 14 / 2012$ & 2/7/2013 & 395 & 847 & 3,740 & -- & 15,600 \\
\hline PNM (as per NMED) & SJGS & MW4 & 3 & 9/6/2012 & 3/6/2013 & 450 & 73 & 418 & -- & 5,253 \\
\hline PNM (as per NMED) & SJGS & NEP3 & 3 & 9/6/2012 & 3/6/2013 & 398 & 401 & 2,160 & -- & 10,433 \\
\hline PNM (as per NMED) & SJGS & NEP4 & 3 & 9/6/2012 & 3/6/2013 & 417 & 568 & 2,343 & -- & 13,900 \\
\hline PNM (as per NMED) & SJGS & QAL1 & 3 & 9/6/2012 & 3/6/2013 & 475 & 937 & 1,573 & -- & 8,827 \\
\hline PNM (as per NMED) & SJGS & QAL2 & 3 & 9/6/2012 & 3/6/2013 & 434 & 248 & 1,190 & -- & 7,643 \\
\hline PNM (as per NMED) & SJGS & QAL3 & 3 & 9/6/2012 & 3/6/2013 & 422 & 278 & 1,653 & -- & 8,933 \\
\hline PNM (as per NMED) & SJGS & QNT & 9 & 2/13/2012 & $1 / 23 / 2013$ & 347 & 2,119 & 5,136 & 10,533 & 19,189 \\
\hline PNM (as per NMED) & SJGS & RTW & 3 & $1 / 23 / 2013$ & 3/6/2013 & 402 & 3,520 & 7,337 & -- & 28,033 \\
\hline MMD reporting & SJM & GE & 12 & 9/13/2011 & $10 / 16 / 2013$ & 432 & 1,775 & 4,340 & 10,342 & 18,008 \\
\hline
\end{tabular}




\section{Hogback Monocline}

The Hogback monocline and nearby uplifted areas demark the boundary between the entire San Juan Basin and the central basin (Woodward and Callendar, 1977; Craigg, 2001). At the Hogback monocline, beds reportedly dip as much as 23 degrees toward the lowest part of the basin (Strobell and others, 1980). The dip decreases markedly within short distances away from the Hogback monocline so that at and near the SJM, beds generally dip to the east or southeast at about 2 degrees (Metric Corporation, 2007; MMD, 2017b). The dip of the Kfn8 varies from 3 to 1 degrees at the SJM (Mercier, 2010).

In the study area, the crest of the Hogback monocline is composed mainly of Late Cretaceous-age sandstone tongues identified variously as Kch (Kernodle, 1996; Craigg, 2001) or as an unnamed sandstone tongue of the Kls (Strobell and others, 1980). In the northern part of the study area, the Hogback monocline is not as pronounced as it is on the western boundary of the study area and may indicate greater hydraulic connectivity than the hydraulic disconnection of the Kch along the monocline that is easily observed at the western study area boundary (Strobell and others, 1980).

\section{Cretaceous Cliff House Sandstone}

The Cliff House Sandstone (Kch) (named by Collier, 1919, according to Kernodle, 1996) is the topmost unit of the Mesaverde Group of Late Cretaceous age (Stone and others, 1983). The Kch overlies and intertongues with an older coal-bearing bed of the Mesaverde Group, both conformably and unconformably, depending on location (Craigg, 2001). The Kch is a tan, light brown or yellowish-brown, thickbedded, very fine- to fine-grained coastal-marine subarkosic sandstone (Stone and others, 1983; Craigg, 2001). The unit was described by Fassett (1977) as being composed of thickbedded basal sandstone lenses and at least two thick and several thinner sandstone tongues of varying extent, thickness, and interconnectedness. Regional correlation of the locations and interconnectedness of sandstone tongues is complicated by the complex depositional history of the Kch (Stone and others, 1983; Kernodle, 1996; Craigg, 2001).

The upper Kch tongue was unnamed by Fassett (1977) and elsewhere is informally called the Chacra Tongue or the Tsaya Canyon Tongue (Dane, 1936; Fassett, 1977; Stone and others, 1983). This sandstone tongue is identified as a potential gas reservoir east of the present study area (Dubiel, 2013) and is the Kch member that generally crops out at the Hogback monocline in the study area and elsewhere around the margins of the central basin (Kernodle, 1996). Dane (1936) and Molenaar (1977) noted that this tongue of the Kch ranges in thickness from $46 \mathrm{~m}(150 \mathrm{ft})$ to $110 \mathrm{~m}$ (360 ft) at locations southeast of the study area (Dane, 1936; Fassett, 1977; Craigg, 2001) and is disconnected from the lower La Ventana Tongue (Dane, 1936; Fassett, 1977; Dubiel, 2013). Elsewhere in the basin, the undifferentiated Kch is described as ranging from 6 to $75 \mathrm{~m}$ (20 to $245 \mathrm{ft}$ ) thick (Stone and others, 1983) and ranging from not present in southwestern parts of the basin to more than $245 \mathrm{~m}$ (800 ft) thick east of the present study area (Molenaar, 1977; Stone and others, 1983).

Stone and others (1983) reported that measured Kch transmissivities range from 0.2 to $5.6 \mathrm{~m}^{2} / \mathrm{d}\left(2\right.$ to $\left.60 \mathrm{ft}^{2} / \mathrm{d}\right)$. Kernodle (1996) applied a value of $0.0305 \mathrm{~m} / \mathrm{d}(0.1 \mathrm{ft} / \mathrm{d})$ to represent horizontal saturated hydraulic conductivity and a value of $3.0408 \times 10^{-4} \mathrm{~m} / \mathrm{d}(0.001 \mathrm{ft} / \mathrm{d})$ to represent vertical saturated hydraulic conductivity.

In oil-field literature intrinsic permeability is a measure of fluid flow through a porous medium. Permeability values, in units of milliDarcys (mD), are often reported in lieu of saturated hydraulic conductivity values. One $\mathrm{mD}$ is equal to one-thousandth of a Darcy; a mD is defined in centimetergram-second units, and incorporates consideration of fluid dynamic viscosity, temperature, and air-pressure (Freeze and Cherry, 1979; Schlumberger, 2017). Dugal and Soni (1996) note that at $20^{\circ} \mathrm{C}$ the permeability value of 1 darcy (D) is equivalent to a hydraulic conductivity value of $0.831 \mathrm{~m} / \mathrm{d}$ $(2.73 \mathrm{ft} / \mathrm{d})$. For the conversions from permeability to hydraulic conductivity reported here, standard temperature, pressure, and freshwater density were assumed. The hydraulic conductivity values converted with these simplifications should be considered as estimates only.

Reneau and Harris (1957) reported a value of $0.54 \mathrm{mD}$ for the intrinsic permeability of the Kch, which converts to an estimated value of hydraulic conductivity of $4.5 \times 10^{-4} \mathrm{~m} / \mathrm{d}$ $\left[0.0015 \mathrm{ft} / \mathrm{d}\right.$ for water at $20^{\circ} \mathrm{C}\left(68^{\circ} \mathrm{F}\right)$. They reported a range of porosities of between 3.0 and 17.2 percent for the Kch, with an average porosity of 10.3 percent. Dubiel (2013) reported that the La Ventana and Chacra tongues of the Kch have porosities ranging between 8 and 14 percent, and intrinsic permeabilities between 0.15 and $0.3 \mathrm{mD}$, respectively, from gas well testing. These intrinsic permeability data represent estimated saturated hydraulic conductivity values ranging between $1.3 \times 10^{-4}$ and $2.5 \times 10^{-4} \mathrm{~m} / \mathrm{d}\left(4 \times 10^{-4}\right.$ and $\left.8 \times 10^{-4} \mathrm{ft} / \mathrm{d}\right)$, respectively (Dubiel, 2013). Hoppe (1978) reported the porosity of the Chacra Tongue at a gas well in San Juan County, N. Mex., as between 4 and 6 percent.

Vertical or horizontal gradients, if present, may yield small volumes of groundwater flow into and out of the Kch from adjacent water-bearing strata (Lyford, 1979). The current study area, in a simplified potentiometric-surface map of the Kch water-bearing unit (Stone and others, 1983), is shown as having a hydraulic-head configuration dissimilar to and equipotential values almost $100 \mathrm{~m}$ (several hundred feet) lower than results of the Kernodle (1996) numerical model.

\section{Cretaceous Lewis Shale}

The Lewis Shale (Kls) of Cretaceous age (named by Collier, 1919, according to Dubiel, 2013) conformably overlies and intertongues with the Kch (Kernodle, 1996; Craigg, 2001) and crops out adjacent (toward the central basin interior) to the Kch. The Kls is a light gray to black marine shale with interbedded sandstone and limestone lenses and regionally extensive bentonite beds that are used 
as stratigraphic markers (Fassett and Hinds, 1971; Molenaar, 1977; Ayers and others, 1994). In the central basin, the Kls is absent at the southwestern margin and present with a thickness of as much as $730 \mathrm{~m}(2,400 \mathrm{ft})$ at the northeastern margin (Fassett and Hinds, 1971; Dubiel, 2013). The Kls is present throughout the study area.

The Kls is an aquitard and acts as a confining unit between underlying and overlying sandstone units (Craigg, 2001). No groundwater wells are known to exist in the Kls, and no Kls hydraulic characteristics were found in the literature. However, Dubiel (2013) reported that between 1991 and 1997, following renewed interest in shale-gas reservoirs (U.S. Energy Information Administration, 2011), many methane-extraction wells completed in deeper units in the San Juan Basin were recompleted in the Kls. The Kls intrinsic permeability values reported from associated gas well tests ranged from $10^{-4}$ to $10^{-8} \mathrm{mDs}$ representing estimates of hydraulic conductivity values ranging from $8.3 \times 10^{-8} \mathrm{~m} / \mathrm{d}$ to $8.3 \times 10^{-12} \mathrm{~m} / \mathrm{d}\left(2.7 \times 10^{-7} \mathrm{ft} / \mathrm{d}\right.$ to $2.7 \times 10^{-11} \mathrm{ft} / \mathrm{d}$, respectively, with and without consideration of shale-matrix fracturing; Neuzil, 1994; Lewis and others, 2004; Dubiel, 2013). Dubiel (2013) reported that Kls water saturation (ratio of water volume to pore volume) ranges between 20 percent and 100 percent and averages about 70 percent, where Kls average porosity ranges between 2 and 8 percent. U.S. Energy Information Administration (2011) estimated Kls porosity at 3.5 percent.

Specific storage values for shales are rarely reported. Values taken from a study of the Dakota aquifer range from $3 \times 10^{-7} / \mathrm{m}$ to $6 \times 10^{-6} / \mathrm{m}\left(1 \times 10^{-6} / \mathrm{ft}\right.$ to $2 \times 10^{-5} / \mathrm{ft}$; Bredehoeft and others, 1983); Freeze and Cherry (1979) report the range for shales may extend to as low as $1 \times 10^{-7} / \mathrm{m}\left(3 \times 10^{-8} \mathrm{ft}\right)$. Numerical modeling results (Frenzel and Lyford, 1982) indicate net upward groundwater flux through the Kls confining unit in the San Juan River portion of the San Juan Basin to be about $8,100 \mathrm{~m}^{3} / \mathrm{d}\left(286 \times 103 \mathrm{ft}^{3} / \mathrm{d}\right)$.

\section{Cretaceous Pictured Cliffs Sandstone}

The Pictured Cliffs Sandstone (Kpc) of Late Cretaceous age (named by Holmes, 1877, according to Kernodle, 1996) is a marine coastal barrier deposit and represents the final regression of the Cretaceous-age Western Interior Seaway (Molenaar, 1977; Ayers and others, 1994; Kernodle, 1996). The Kpc conformably overlies and intertongues with the Kls (Ayers and others, 1994; Craigg, 2001). The upper two-thirds of the Kpc consist of a light gray, very fine- to mediumgrained, massive, bioturbated, immature to supermature subarkosic sandstone (Stone and others, 1983; Myers and Villanueva, 1986; Ayers and others, 1994; Kernodle, 1996). In some parts of the study area, the uppermost Kpc contains a well-indurated coquinoid limestone bed (Norwest Corporation, 2012). The lower third of the unit consists of interbedded shoreface mudstones and sandstones (Stone and others, 1983; Myers and Villanueva, 1986; Ayers and others, 1994; Craigg, 2001). Baltz (1967) mapped the Kpc as present in the central basin except where it has eroded away adjacent to the Kls surficial outcrop near the Hogback monocline. The total thickness of the Kpc varies but averages $37 \mathrm{~m}(120 \mathrm{ft})$ in the mine area (Luther and others, 2005; MMD, 2017b).

Although the Kpc bears water (Luther and others, 2005), Stone and others (1983) noted that saturated hydraulic conductivities (or transmissivities) of this unit and all of the Cretaceous sandstone water-bearing units in the study area "are generally low, because of their fine-grained texture." Low groundwater recovery rates to previously measured static heads (of more than 2 days) were observed at well KPC1 following pumping for groundwater sampling (Stewart and Thomas, 2015). Groundwater abundance and hydraulic conductivity of the Kpc may be related to the presence or absence of fractures. The locations and orientations of fractures in the Kpc in the study area are not known, although they have been described by Condon (1999) and Cox and others (2001) in Colorado, north of the present study area.

Myers and Villanueva (1986) reported that Kpc water is brackish. Lithologic logs and depth-to-water data (Stewart and Thomas, 2015) indicate that groundwater in the Kpc, distant from recharge areas, is generally under confined but not flowing conditions. Saturated hydraulic conductivity was estimated at $0.0032 \mathrm{~m} / \mathrm{d}(0.0105 \mathrm{ft} / \mathrm{d})$ on the basis of an aquifer test at well GA (fig. 1A, MMD, 2017b). Stone and others (1983) reported a saturated hydraulic conductivity value of $0.00213 \mathrm{~m} / \mathrm{d}(0.007 \mathrm{ft} / \mathrm{d})$.

\section{Cretaceous Fruitland Formation and Kirtland Shale}

The Fruitland Formation (Kf) of Cretaceous age conformably overlies the Kpc with local intertonguing at the Kf-Kpc contact (Berry, 1959; Craigg, 2001). The Kf is composed of interbedded fine- to medium-grained nonmarine sandstone lenses, siltstones, sandy and silty claystones, carbonaceous claystones, bentonitic claystones, and coal seams of various thicknesses (Craigg, 2001). At the SJM, mined coal seams were overlain with surficial top soil and interbedded with well-graded $\mathrm{Kf}$ surface-mining debris, which when pulverized during mining is the main constituent of mine spoil.

The Kirtland Shale (Kks) conformably overlies the Kf (MMD, 2017b). The Kks is composed of a sandstone member interbedded between two shale members and otherwise displays lithology similar to the Kf except that it does not contain coal (Myers and Villanueva, 1986; Craigg, 2001). Following the conceptual model of Kernodle (1996), for this project the Kks and the Kf (with the exception of the mined coal seam) were undifferentiated as the Kirtland/Fruitland Formation (Kkf) of Cretaceous age (both formations were named by Bauer, 1916, according to Kernodle, 1996). The combined thickness of the Kkf in the San Juan Basin varies from not present at the western part of the study area to as

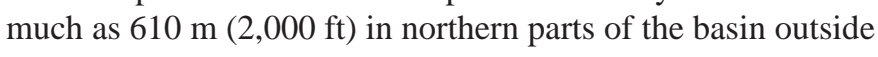
of the study area (Craigg, 2001). Kaiser and others (1994) developed a potentiometric map of the Kkf using pressure data from oil and gas wells. Myers and Villanueva (1986) reported 
that Kkf groundwater is brackish. Kernodle (1996) estimated the horizontal hydraulic conductivity of the Kkf to be $3.048 \times 10^{-3} \mathrm{~m} / \mathrm{d}(0.01 \mathrm{ft} / \mathrm{d})$ and vertical hydraulic conductivity to be $3.048 \times 10^{-5} \mathrm{~m} / \mathrm{d}(0.0001 \mathrm{ft} / \mathrm{d})$.

Nickelson (1988) noted that the basal Kf coal bed is variously called the Carbonero and Carbona. Lakes (1889) described the occurrence, in the Durango district of Colorado, of a thick coal seam that appeared to be regionally continuous, which he called the Carbonero. Fassett (2000), however, noted that the $\mathrm{Kf}$ coal beds occur in lenses, and although coal is present throughout the $\mathrm{Kf}$, the lenses are locally but not regionally continuous. Locally, the basal Kf coal bed is called the Number 8 coal seam (Kfn8) (Nickelson, 1988; Mercier, 2010; MMD, 2017b). The Kfn8 is located above a $\mathrm{Kf}$ shale lens that rests, where present, on top of the Kpc. The thickness of the shale lens ranges from not present to $13 \mathrm{~m}$ (43 ft), averages 3 m (10 ft; Mercier, 2010; MMD, 2017b), and is generalized as not present in regional studies (Myers and Villanueva, 1986; Ayers and Zellers, 1994).

The SJGS mine-mouth generating station and the minemouth SJM straddle the outcrop of the Kfn8 to the west and to the east, respectively. The western boundary of former surface mine pits generally demarks the north-south trending contact between the Kf basal coal seam and the underlying Kpc; this contact represents the western limit of surface mining. The eastern limit of surface mining varies depending on the depth and quality of the Kfn8 coal. Between the western and eastern boundaries demarking the limits of surface mining, CCB ash is stored in a subset of the reclaimed surface-mine pits (figs. $1 A$, $2 A$, and $2 B$ ).

In the central San Juan Basin, the total combined thickness of coal seams ranges from 6 to $24 \mathrm{~m}$ (20 to $80 \mathrm{ft}$; $\mathrm{EPA}, 2004)$. In the study area, the Kfn8 ranges in thickness from $1 \mathrm{~m}$ (3 ft) to as much as $9 \mathrm{~m}$ (30 ft; Nickelson, 1988; Mercier, 2010). At the SJM underground lease area, the Kfn8 averages $5 \mathrm{~m}$ (16 ft) in thickness and is overlain by interbedded shale and sandstone of variable thickness, which averages about $30 \mathrm{~m}(100 \mathrm{ft})$ at the underground mine, and then by a coal seam $2 \mathrm{~m}$ or less (6.3 ft) thick (Beach and Jentgen, 1978), locally called the number 9 coal seam (Mercier, 2010; MMD, 2017b). The SJM Kf coal seams contain 0.80 percent sulfur and 20 percent ash (such "natural" ash, while incombustible, is assumed to represent a large but unknown fraction of CCB ash after combustion); the Kf coal seams at La Plata mine (fig. 1A, see LPMKPC1 well for general location) contain 0.9 percent sulfur and 22 percent ash (Nickelson, 1988). Both the number 8 (Kfn8) and number 9 coal seams were surface-mining targets at SJM (MMD, 2014a).

Regionally, Kkf groundwater in permeable zones such as coal seams is thought to be recharged in highland areas and to flow from these areas toward either natural discharge areas, such as the San Juan River, or to oil and gas pumping centers located east of the SJM in the study area (Kaiser and others, 1994). The San Juan River and other perennially flowing rivers are thought to be natural Kkf discharge locations (Kernodle, 1996); however, mine and oil and gas well dewatering may have reversed Kfn8 groundwater-flow directions, drawing San Juan River alluvial groundwater into the underground mining area (inferred from 2008 potentiometric-surface contours of the Kfn8 (Mining and Minerals Division of New Mexico Energy, Minerals and Natural Resources Dept., written commun., 2010). At the southern study area boundary, the top of the Kfn8 can be traced from a subcrop at the San Juan River, at an elevation of approximately 1,555 m (5,100 ft; Mining and Minerals Division of New Mexico Energy, Minerals and Natural Resources Department, written commun., 2010), to SMJ-24-4 at the central-eastern edge of the SJM lease area extension, at an elevation of approximately 1,401 m (4,596 ft) to SMJ$13-2$ at the north-central edge of the lease area extension, at an elevation of approximately 1,412 m (4,634 ft; Beach and Jentgen, 1978; MMD, 2014a). Under natural conditions, Kfn8 groundwater is confined, with measured pressure heads that vary spatially, and likely temporally, between $15 \mathrm{~m}$ and $93 \mathrm{~m}$ (50 ft and $306 \mathrm{ft}$ ) above the top of the coal seam (MMD, 2017b).

The Kf coal seams are believed to be the most permeable water-bearing members of the Kf (Stone and others, 1983; Kaiser and others, 1994), although Kkf sandstone lenses present above coal seams are also known to locally bear water (Myers and Villanueva, 1986). Stone and others (1983) reported Kfn8 transmissivities ranging between $0.028 \mathrm{~m}^{2} / \mathrm{d}$ and $12.1 \mathrm{~m}^{2} / \mathrm{d}\left(0.6 \mathrm{ft}^{2} / \mathrm{d}\right.$ and $\left.130 \mathrm{ft}^{2} / \mathrm{d}\right)$ in the Kfn8. MMD (2017b) reported a saturated hydraulic conductivity value for the Kfn8 to be $0.005 \mathrm{~m} / \mathrm{d}(0.017 \mathrm{ft} / \mathrm{d})$.

\section{Cretaceous-Tertiary Animas Formation and Ojo Alamo Sandstone and Tertiary Nacimiento Formation}

Stone and others (1983) reported that the Animas Formation (variously found in the literature as either Tertiary or Cretaceous-Tertiary in age, and herein described as Cretaceous-Tertiary, TKa) was named by Cross (Emmons and others, 1896) and Gardner (1909). The CretaceousTertiary age Ojo Alamo Sandstone (also variously found in the literature as either Tertiary or Cretaceous Tertiary in age, and herein is described as Cretaceous-Tertiary, TKoa) was named by Brown (1910, according to Fassett, 1973). The Tertiary-age Nacimiento Formation (Tn) was named by Keyes (1906) according to Stone and others (1983). The TKoa, TKa, and Tn are present at higher elevations in the study area and are eroded and not present in the La Plata River Valley south of Piñon Mesa (figs. 2A and 2B). The TKa is composed of two members, the older of which is Cretaceous in age and the younger of which is Tertiary in age (Paleocene). Both members are composed of tuffaceous sandstone interbedded variously with volcanic material and shale (Kernodle, 1996). The lower, older TKa member is located below the TKoa in the study area, and the upper, younger member, not present in the study area, elsewhere is located above the TKoa (Stone and others, 1983; Kernodle, 1996). The TKoa is composed of 
lenses of sandstone, conglomeratic sandstone, and shale and ranges in thickness from $21 \mathrm{~m}$ to $61 \mathrm{~m} \mathrm{(70} \mathrm{ft} \mathrm{to} \mathrm{about} 200 \mathrm{ft}$; Kernodle, 1996). Stone and others (1983) and Kernodle (1996) describe that where the TKoa is continuous and thick, east of the study area, it contains a regionally important confined aquifer.

The Tertiary-age Nacimiento Formation (Tn) is composed of nonresistant, slope-forming interbedded shale and poorly consolidated sandstone lenses (Kernodle, 1996) and conformably overlies the TKoa in some places and elsewhere grades into the TKoa (Stone and others, 1983). Kernodle (1996) and Stone and others (1983) reported that few data exist that describe hydrologic properties of the TKa and Tn. Stone and others (1983) noted that the sandstone lenses in both formations likely bear water, but also inferred that the Tn likely confines groundwater of the underlying TKoa. Kernodle (1996) noted that transmissivities of the TKoa, from aquifer tests in relatively shallow wells, range between $5 \mathrm{~m}^{2} / \mathrm{d}$ and $15 \mathrm{~m}^{2} / \mathrm{d}\left(57 \mathrm{ft}^{2} / \mathrm{d}\right.$ and $\left.164 \mathrm{ft}^{2} / \mathrm{d}\right)$, whereas transmissivities in deep wells are much less and range between $0.005 \mathrm{~m}^{2} / \mathrm{d}$ and $0.036 \mathrm{~m}^{2} / \mathrm{d}\left(0.05 \mathrm{ft}^{2} / \mathrm{d}\right.$ and $\left.0.39 \mathrm{ft}^{2} / \mathrm{d}\right)$. Stone and others (1983) noted that TKoa transmissivities range between $4.7 \mathrm{~m}^{2} / \mathrm{d}$ and $23 \mathrm{~m}^{2} / \mathrm{d}\left(50 \mathrm{ft}^{2} / \mathrm{d}\right.$ and $\left.250 \mathrm{ft}^{2} / \mathrm{d}\right)$ and decrease toward the north. Although no saturated thickness values were identified, to convert transmissivity values to estimates of saturated hydraulic conductivity, Kernodle (1996) assumed, for numerical modeling, horizontal saturated hydraulic conductivity values for the TKoa of $0.3 \mathrm{~m} / \mathrm{d}(1.0 \mathrm{ft} / \mathrm{d})$ and for the $\mathrm{Kkf}$ of $0.003 \mathrm{~m} / \mathrm{d}(0.01 \mathrm{ft} / \mathrm{d})$ and generated spatiallydesignated horizontal-hydraulic conductivity values based on weighted thicknesses of the two units. This process yields an initial horizontal saturated hydraulic conductivity value of $0.006 \mathrm{~m} / \mathrm{d}(0.02 \mathrm{ft} / \mathrm{d})$ for this study area for undifferentiated $\mathrm{Kkf} / \mathrm{TKoa} / \mathrm{TKa} / \mathrm{Tn}$.

\section{Quaternary Eolian Dune-Sand Deposits and Alluvium}

Undifferentiated Quaternary Naha and Tsegi (Qnt; National Geologic Map Database, 2014) eolian dune-sand deposits cover much of the study area surface (Hack, 1941; Strobell and others, 1980). Unconsolidated to partially consolidated Qnt is also present as fill of paleochannels that were cut into the Kch, Kls, Kpc, and Kkf (Metric Corporation, 1982, 2007). Modern ephemeral stream channels may either dissect surficial Qnt deposits or track over Qnt-filled paleochannels (Strobell and others, 1980). The Shumway and Westwater Arroyos Quaternary alluvium (Qal) fill is derived mainly from retrenched and reworked Qnt eolian deposits combined with larger clasts derived from the Kch, Kls, Kpc, and Kkf (Strobell and others, 1980; Metric Corporation, 1982). Both Qnt and Qnt-derived Qal that is present in arroyos may be remobilized, remixed, and redeposited during ephemeral flow events, depending on the stream power of the flow events.

The thickness of Qnt sediments in study-area arroyos and overbank areas generally varies between $6 \mathrm{~m}$ and $9 \mathrm{~m}$
(20 ft and $30 \mathrm{ft}$ ) but was observed to be as much as $12 \mathrm{~m}$ (40 ft) thick north of the SJGS in the bed of the WWA (upper) (Metric Corporation, 1982). The Qnt deposits were assumed to be continuous across unmapped parts of valley floors.

The Qal in study-area ephemeral-stream channels is $3 \mathrm{~m}$ (10 ft) or less in thickness (Strobell and others, 1980; Metric Corporation, 2007). The Qal is also present in the valley fill of the San Juan and La Plata Rivers. Stone and others (1983) reported that the measured range of thickness of the Qal along the San Juan River and its tributaries is between $12 \mathrm{~m}$ and $30 \mathrm{~m}$ (40 ft and $100 \mathrm{ft}$ ), whereas Strobell and others (1980) estimated the thickness to be greater than $9 \mathrm{~m}$ (30 ft).

The Qal of the Westwater Arroyo is saturated in the mine-permit area (Luther and others, 2005). The Qal of the Shumway Arroyo is saturated in some places (MMD, 2017b), although in at least one SA (upper) Qal/Qnt drill-hole location upgradient from the Shumway Diversion Channel, groundwater was not present in 2013 (Edward Epp, BHP Billiton, oral commun., 2013).

Strobell and others (1980) mapped localized deposits of glacial outwash in the Shumway and Westwater Arroyos (Metric Corporation, 1982; Stone and others, 1983). Glacial outwash is composed of well-rounded boulders, cobbles, and pebbles that were transported from mountainous areas in Colorado to the study area during previous glacial periods (Strobell and others, 1980; Metric Corporation, 2007). For this study, these localized deposits of glacial outwash were considered to be Qal.

\section{Recent Mine Spoil, Coal Combustion Byproducts (Ash), and Subsided Overburden}

Reclaimed surface-mine pits are considered to be part of the hydrostratigraphic framework of the study area and are filled mainly with mine spoil and CCB ash. Mine spoil is waste rock, usually removed by blasting to provide access to target minerals during surface mining. At the SJM, mine spoil is composed of $\mathrm{Kf}$ shale and sandstone that has been broken, during mining, into poorly sorted pieces ranging in particle size from dust to large boulders. During surfacemining operations, SJM collected and stockpiled topsoil and mine spoil to be used for cover and fill, respectively, of surface-mined pits. When used for this purpose in reclaimed surface-mining areas, these deposits are identified as cover and mine spoil related to reclamation of the former surfacemine pits. Wells completed in these deposits are designated with a primary aquifer code of 111CRMS in table 1. This code is also used to designate the primary aquifer code for wells in the USGS National Water Information System (NWIS) database (U.S. Geological Survey, 2012-14). The porosity of mine spoil was estimated by Metric Corporation (1990) to be 40 percent. Metric Corporation (1990) estimated that the resaturation of surface-mining pits will take about 300 years, based on the assumption that the groundwater source would be Fruitland coal seams. Thomson and others (2012) investigated the hydraulic properties of mine spoil, noted it is used for 
cover and for interbedding with CCB ash and found it has a large fraction of swelling clay (smectite), which accounted for its low hydraulic conductivity and associated infiltration rates of less than 0.004 meter per year (m/yr) (0.013 foot per year $[\mathrm{ft} / \mathrm{yr}])$.

The SJGS produces three types of CCBs: (1) fly ash, (2) bottom ash, and (3) flue gas desulfurization material (Thomson and others, 2012). Fly ash from the SJGS is composed of particles of amorphous aluminosilicate glass consisting mainly of quartz and mullite (a type of clay formed at high temperatures) with some hematite. Fly ash particles are sufficiently fine grained to become entrained in burner exhaust and are recovered by scrubbers or by electrostatic precipitators. The particle size of some of the combusted ash precludes entrainment in burner exhaust, so it falls to and is recovered from the bottom of burners and is thereafter characterized as "bottom ash." Bottom ash mineralogical composition is similar to fly ash, consisting mainly of particles of mullite and quartz with calcite and various feldspars (Thomson and others, 2012). During the early 1980s, SJGS annually generated about $48,200 \mathrm{~m}^{3}\left(1.7 \times 10^{6} \mathrm{ft}^{3}\right)$ of ash and scrubber waste (Mining and Minerals Division of New Mexico Energy, Minerals and Natural Resources Dept., written commun., 2010). Thomson and others (2012) reported that fly ash contains 85.4 percent fines, whereas bottom ash contains 22.3 percent fines (by weight) and noted large ranges of measured porosities and saturated hydraulic conductivities for fly ash and bottom ash samples as a function of the degree to which tested samples were compacted. Thomson and others (2012) suggest that hydraulic properties for buried ash are likely a function of overburden pressure. They found saturated hydraulic conductivity of tested fly ash was $0.086 \mathrm{~m} / \mathrm{d}$ $(0.283 \mathrm{ft} / \mathrm{d})$, bottom ash was $4.3 \mathrm{~m} / \mathrm{d}(14.2 \mathrm{ft} / \mathrm{d})$, and mine spoil was as much as $0.0073 \mathrm{~m} / \mathrm{d}(0.024 \mathrm{ft} / \mathrm{d})$ (table 3).

The SJM deposits CCB ash in designated areas of former surface-mine pits and covers successive layers of CCB ash with mine spoil to limit ash dispersion by wind prior to pit closure and covering with top soil (James O'Hara, Director, Mining and Minerals Division of New Mexico Energy, Minerals and Natural Resources Department, oral commun., September 13-17, 2010). Wells completed in fill deposits that include CCB ash are designated as 111CRMSA in table 1 (and in the NWIS database). Thomson and others (2012) conducted an exploratory drilling program to recover CCB ash for testing and reportedly found CCB ash that had been buried without signs of spoil interbedding at one borehole location. Well logs for SM3 and SM4 (Norwest, 2012; fig. 1A) display similar findings.

Thomson and others (2012, also see Parker, 2011) conducted a suite of column-leachate tests to assess potential mobility of metals that may be leached from aged SJM CCB ash, which was recovered after long-term burial. They found that initial leachate concentrations of aluminum, boron, barium, calcium, selenium, silicon, and vanadium, which although low, were higher than in native groundwater; they also found that arsenic concentrations in leachate exceeded the EPA primary drinking-water standard of 10 micrograms per liter. They found that concentrations of tested constituents in CCB leachate were not large enough to indicate potential exceedance of New Mexico groundwater standards for domestic consumption and irrigation use, except for barium and arsenic.

Sulfur, which occurs naturally in Kfn8 coal, is released as sulfur dioxide gas when the coal is combusted. Since 1999, through the time of this assessment, sulfur at SJGS is captured from exhaust gases and is converted into flue gas desulfurization material, which is mineralogically similar to gypsum with some quartz addition (Thomson and others, 2012). Between 1983 and 1999, the disposal mechanism for sulfur wastes at the SJGS is unknown. Prior to 1983, sulfurbearing CCBs were discharged to 001 and 003 outfalls, located within present-day diversion channels (EPA, 2011).

At the SJM underground mine, "rock that overlies the target Kfn8 coal seam in the subsurface is also called overburden, and is subject to subsidence into the void left after the coal seam has been removed, if it is located within the potential fracture zone $* * *$ extending to a maximum height of $47.25 \mathrm{~m}$ (155 ft) above the mineable coal seam" (MMD, 2017b). Subsided overburden is referred to as "gob" in mining parlance (Kentucky Mining Institute, 2014; MMD, 2017b). Gob above mined Kfn8 is expected to subside at an outward angle of between 18 and 23 degrees to an upper limit of $47.25 \mathrm{~m}$ (155 ft as calculated by MMD, 2017b) generating an expanded zone of subsidence around mined-out areas. The SJM expects that subsidence will reduce surface elevations from between $0.5 \mathrm{~m}$ and $2.7 \mathrm{~m}(1.5 \mathrm{ft}$ and $9 \mathrm{ft})$ and is further expected to generate fractures that will close by compression after the subsidence wave has passed (MMD, 2017b).

\section{Groundwater Occurrence}

In the following discussion, the convention for abbreviation of formation-of-well-completion names starts with a capital letter that designates the formation age, followed by lowercase letters that represent an acronym for the formation name, which follows Green and Jones (1997) surficial geology nomenclature. Many study-area wells were assigned names that reference either formations of completion (for example, 'KPC2' indicates completion in the Kpc) or well locations (for example, 'SA' indicates Shumway Arroyo), followed by an alpha-numeric suffix ordered generally by the order in which the wells were constructed. However, monitoring wells completed prior to the 2000s do not follow this convention. In this report, well-name acronyms generally are written in capital letters and are the well names established by SJM and SJGS, except that hyphens have been removed from short well name assignments for this project (table 1). Wells installed to monitor groundwater in reclaimed surfacemine pits are designated "spoil monitoring wells" (SM) and

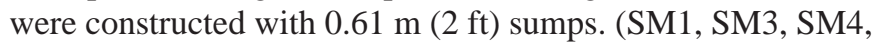
SM8, SM10, and SM11 have been dry throughout the study period, while SM3 and SM4 contained water only in their 
sumps). Groundwater has reentered reclaimed surface-mined areas monitored at SM5, SM6 and SM7 (fig. 1A, insets 1 and 2). Discussion of groundwater recovery observed at SM wells is included in following sections. The well QNT is called Well-QNT in the text of this report only (the short name of the well is listed as "QNT" in table 1), so that readers can plainly distinguish between references to the well and references to the Qnt formation. Figures 3-16 show hydraulic-head relations. Figure 17 shows relations between groundwater chemical constituents.

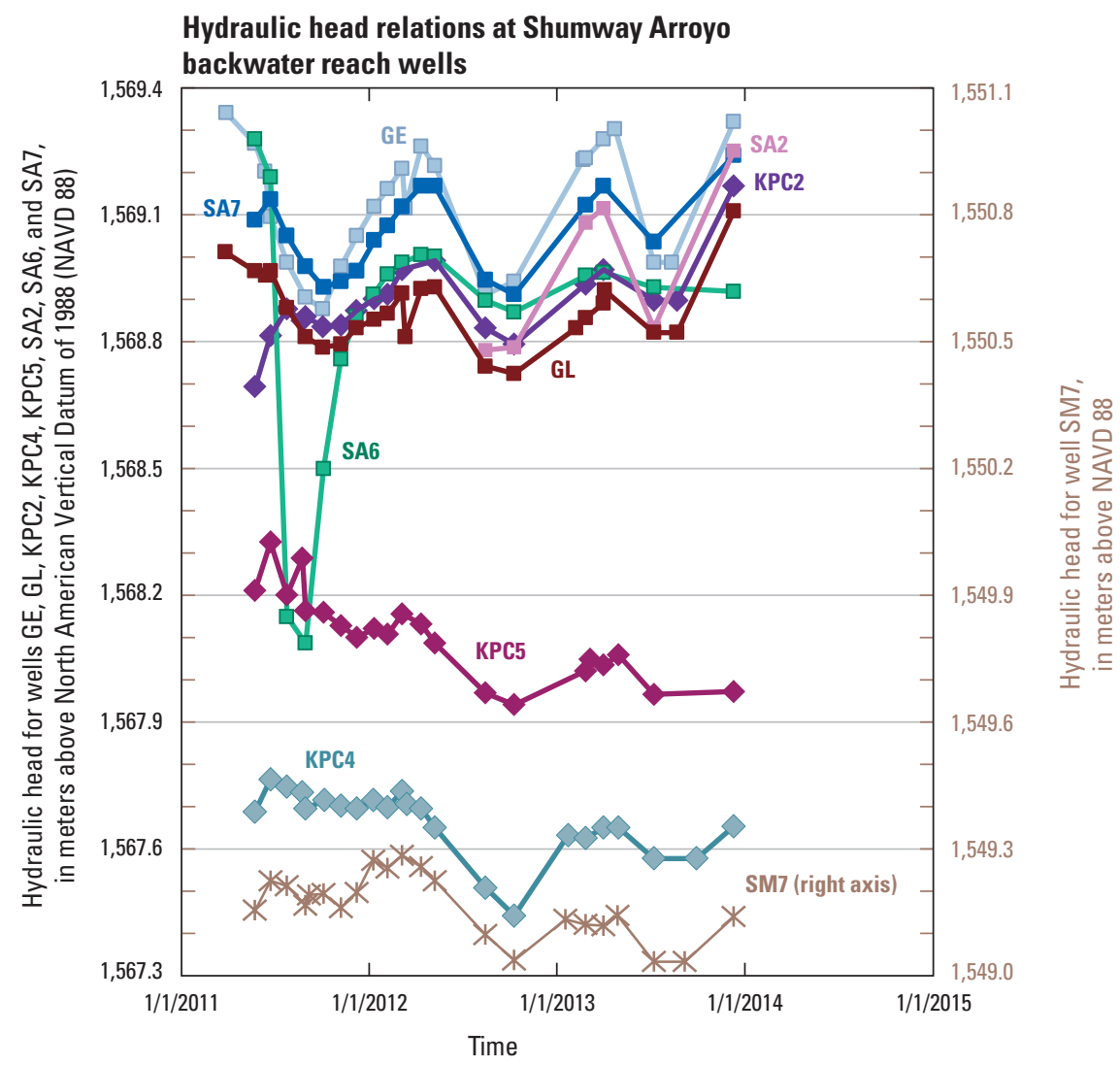

EXPLANATION

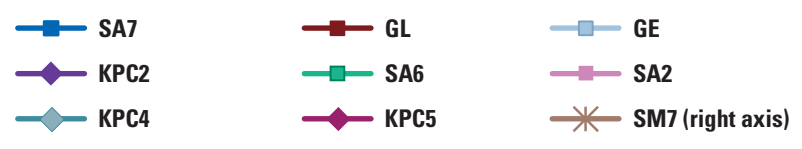

Figure 13. Hydraulic-head relations at Shumway Arroyo backwater reach wells, San Juan County, New Mexico. 


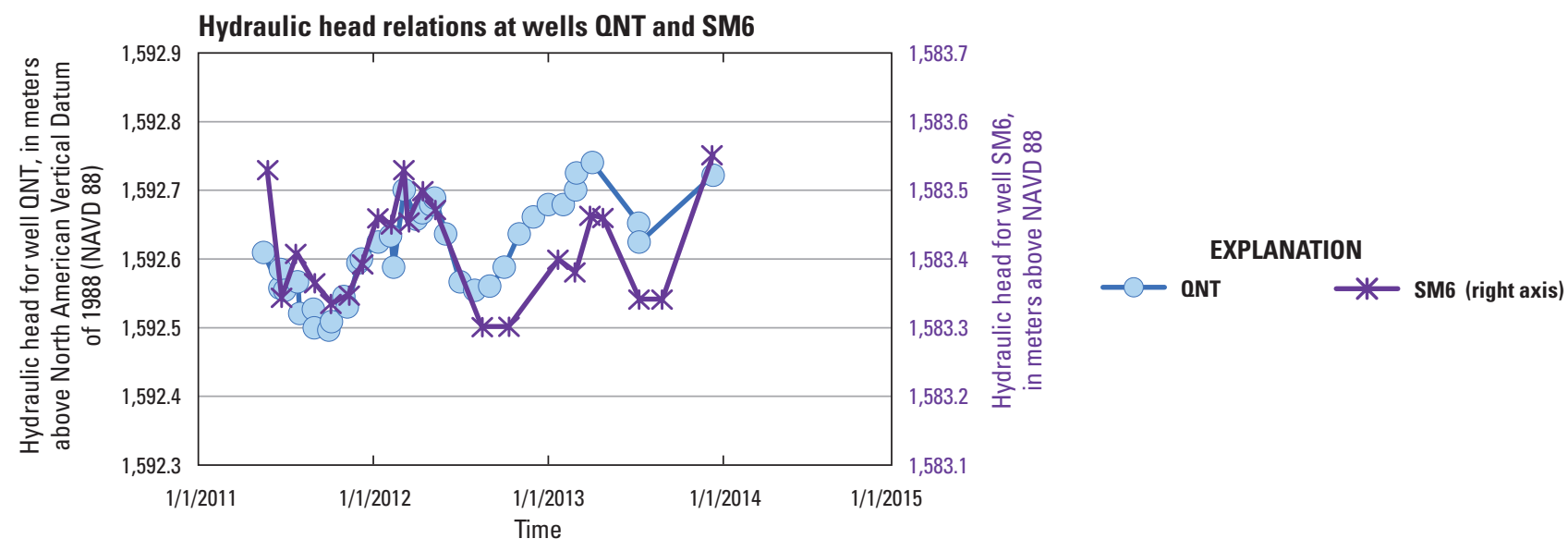

Figure 14. Hydraulic-head relations at wells QNT and SM6, San Juan County, New Mexico.

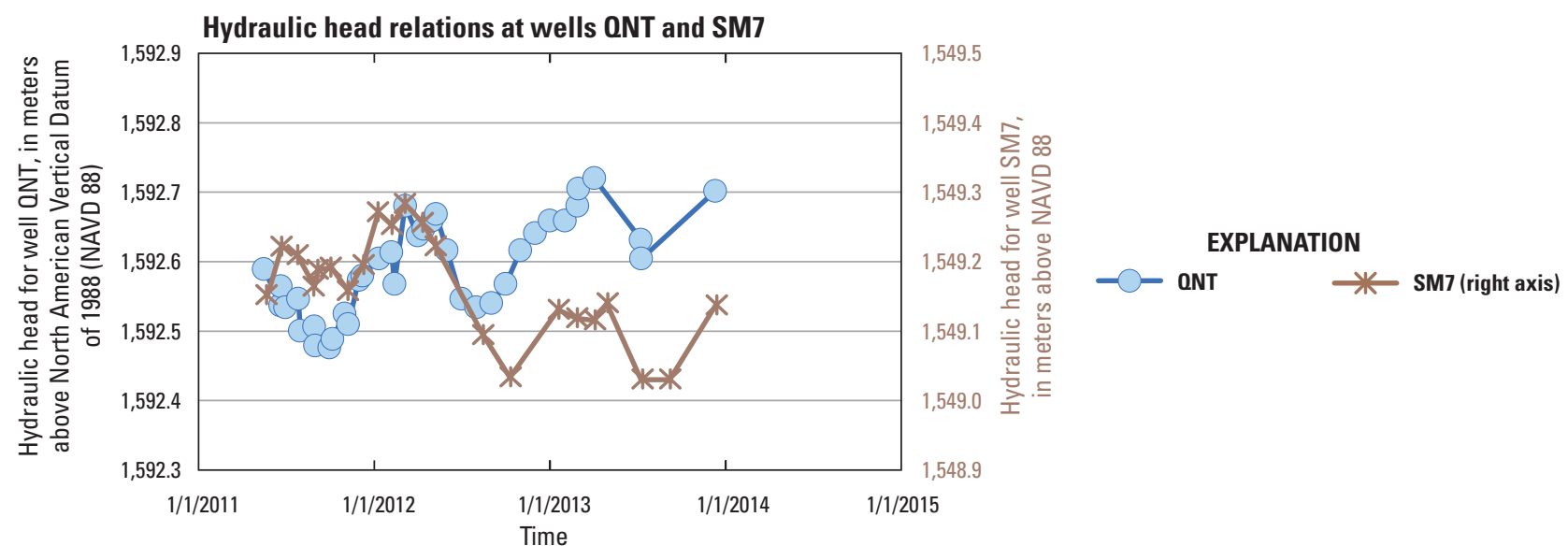

Figure 15. Hydraulic-head relations at wells QNT and SM7, San Juan County, New Mexico.

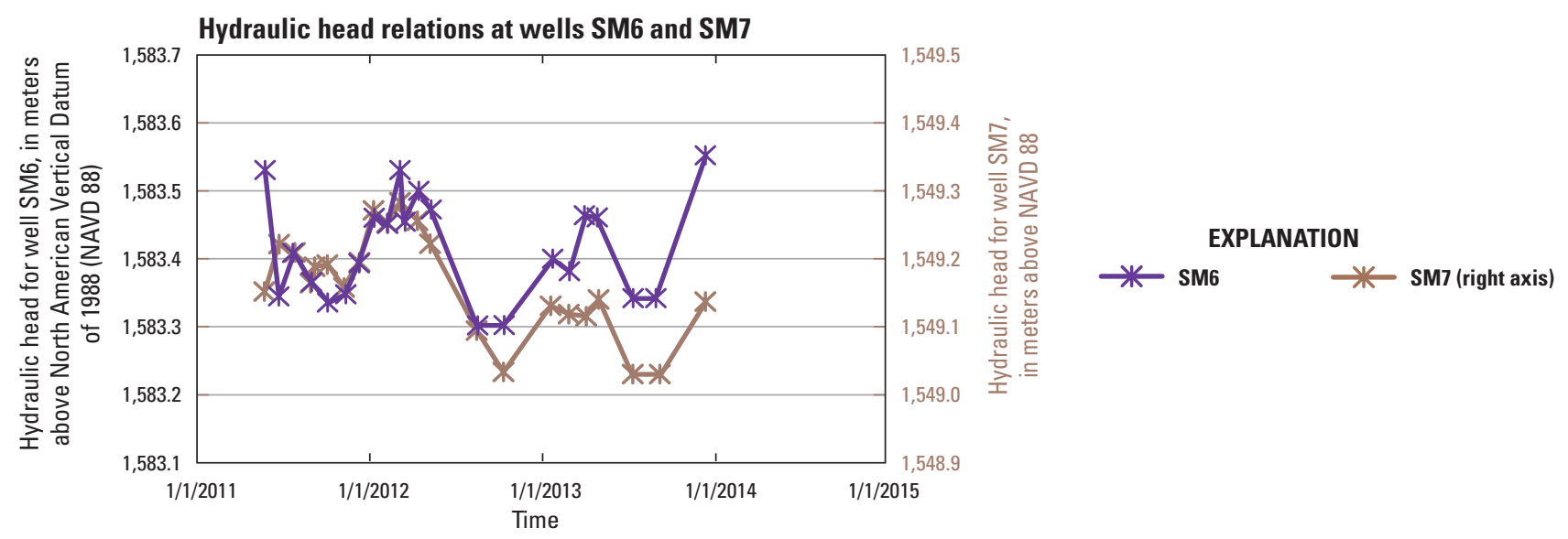

Figure 16. Hydraulic-head relations at wells SM6 and SM7, San Juan County, New Mexico. 


\section{Cliff House Sandstone Groundwater}

In general, the potentiometric configuration and hydraulic stresses on the Kch in the study area are unknown. Although no groundwater-observation wells are known to be completed in the Kch in the study area, several gas extraction wells are completed in the far northeastern part of the study area in the Mesaverde Group. Completions of two of these wells in the Kch cannot be ruled out on the basis of comparison of the true-vertical well-depth data found in the GO-TECH oil and gas well database (well logs API 3004531587 and API 3004560065 (GO-TECH, 2014, 2016) to the expected Kch depth.

The Kch potentiometric-surface map by Stone and others (1983) includes a single east-to-west trending equipotential line in the study area, which allows the inference that those workers concluded that Kch groundwater flows in a southerly direction from northern recharge areas toward the San Juan River alluvium. Conversely, the model-generated potentiometric map by Kernodle (1996) indicates that Kch groundwater in the study area flows in a westerly direction from eastern recharge areas to converge at the Kch subcrop and discharge into San Juan River alluvium near the Hogback monocline.

\section{Lewis Shale Groundwater}

The Kls potentiometric features, groundwater-flow directions, and hydraulic stresses related to groundwater flow are unknown. The locations of Kls retrofitted gas extraction wells, as reported by the U.S. Energy Information Administration (2011) and Dubiel (2013) were not identified from a review of the GO-TECH database. Estimates of hydraulic conductivity of the Kls were calculated from intrinsic permeability data presented by Dubiel (2013) and Lewis and others (2004) and from a discussion of the permeabilities of shale (Neuzil, 1994).

\section{Pictured Cliffs Sandstone Groundwater}

Regionally, Kpc groundwater is believed to flow from recharge sources at the Hogback monocline and from uplifted areas north and east of the study area toward oil and gas well pumping centers in central parts of the study area and along the eastern study area boundary. Along perennially flowing rivers, the Kpc may variably recharge or discharge depending upon locations where subcrops intersect with river alluvium. In the study area, other than oil and gas well extractions, the Kpc is believed to discharge naturally to the San Juan River alluvium (Kernodle, 1996).

A Kpc potentiometric map was not constructed for this report because of a lack of Kpc groundwater observation wells and associated hydraulic-head measurements in the central and southeastern parts of the study area. The following descriptions of Kpc hydraulic-head relations are based on and limited by available Kpc wells and are supported with waterchemistry data (table 4; Stewart and Thomas, 2015; Stewart, 2017).

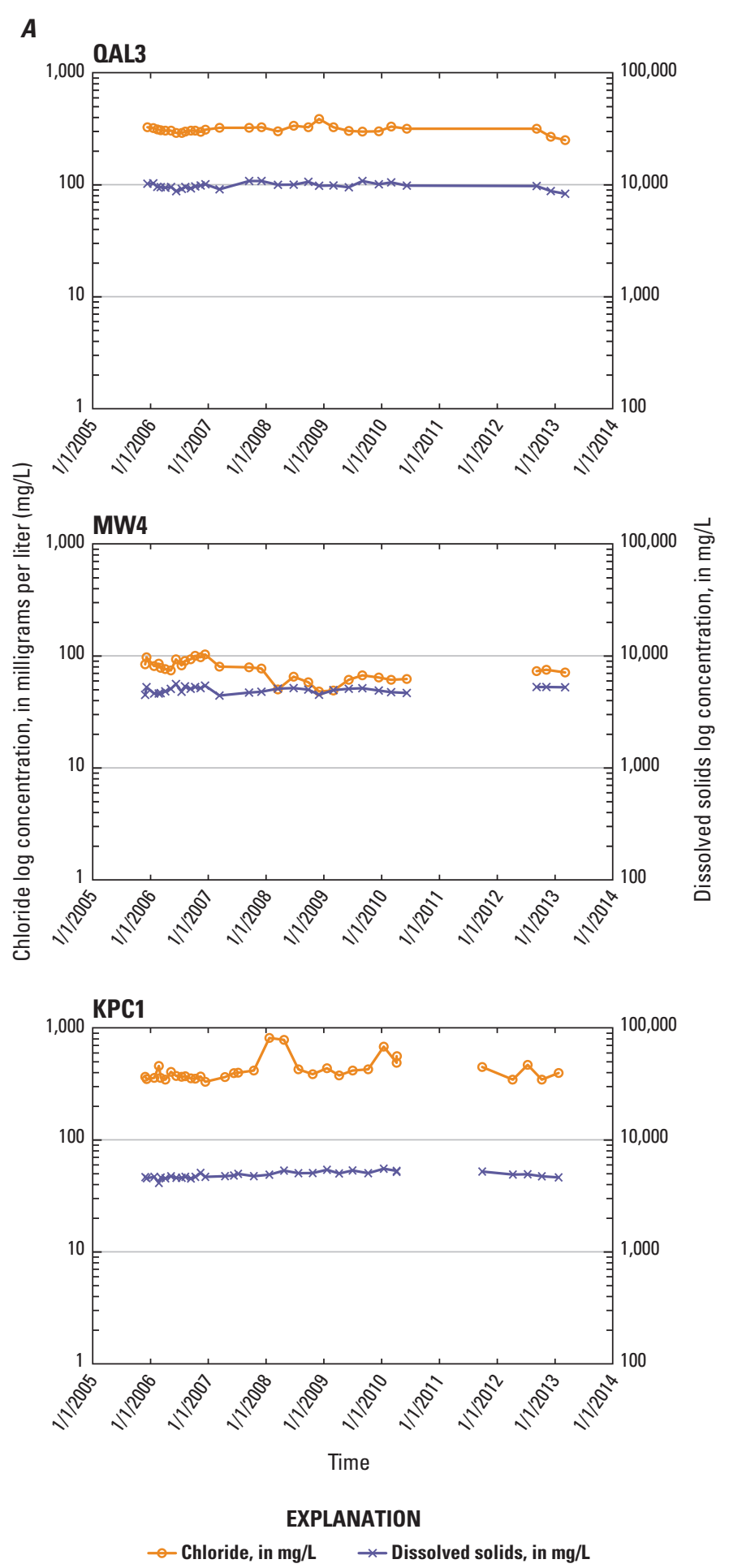

Figure 17. Groundwater chemical constituents at $A$, wells $Q A L 3$, $\mathrm{MW4}$, and $\mathrm{KPC1} B$, wells GE, GL, KPC2, KPC4, and KPC5; and $C$, wells NEP3, NEP4, ONT, and GD. 


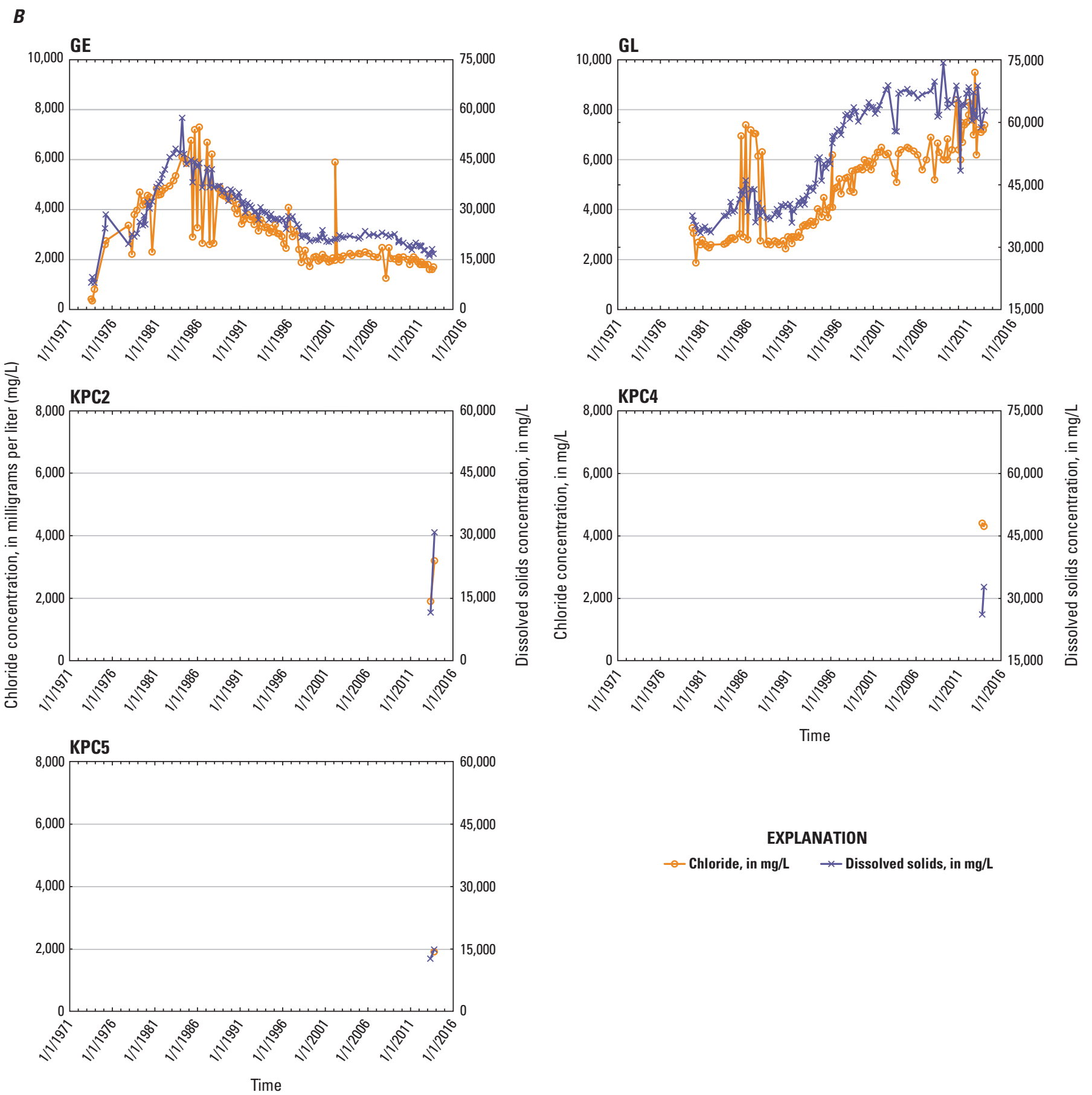

Figure 17. Groundwater chemical constituents at $A$, wells $\mathrm{QAL3}$, MW4, and KPC1; $B$, wells GE, GL, KPC2, KPC4, and KPC5; and $C$, wells NEP3, NEP4, QNT, and GD.-Continued 
C

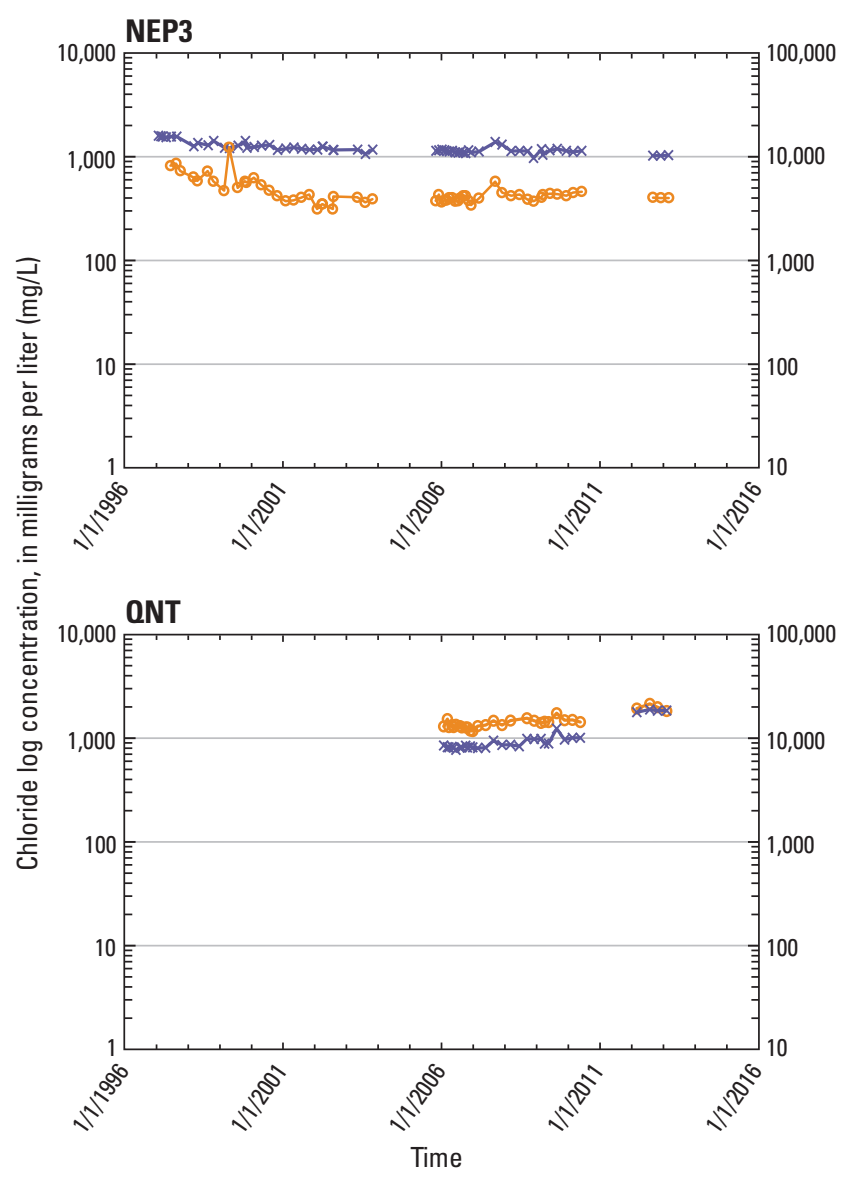

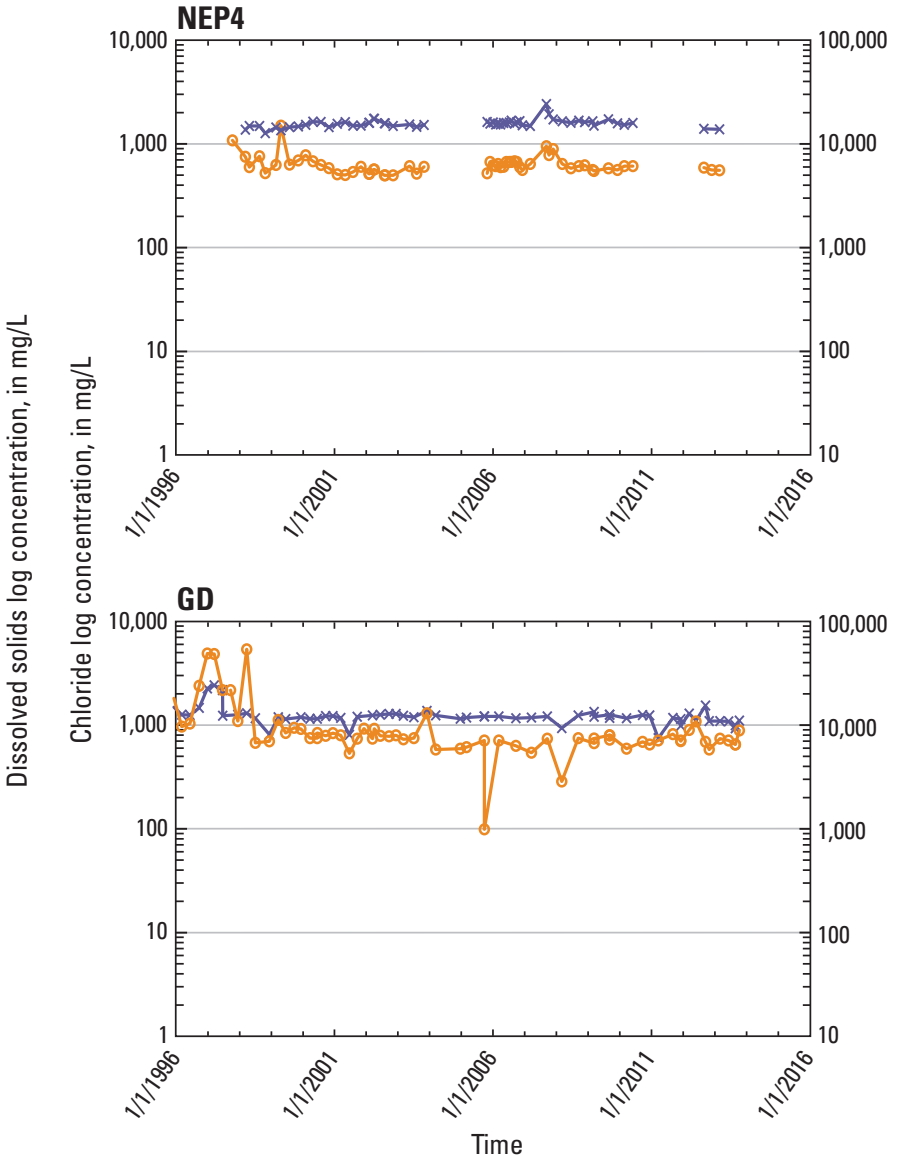

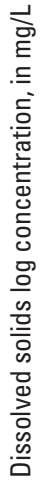

EXPLANATION

$\rightarrow$ Chloride, in $\mathrm{mg} / \mathrm{L} \quad *$ Dissolved solids, in $\mathrm{mg} / \mathrm{L}$

Figure 17. Groundwater chemical constituents at $A$, wells $\mathrm{QAL} 3$, MW4, and KPC1; $B$, wells $\mathrm{GE}$, GL, KPC2, KPC4, and KPC5; and $C$, wells NEP3, NEP4, ONT, and GD.-Continued

Four Kpc regional groundwater monitoring wells with sufficient periods of record to identify long-term trends were available for measuring depths to potentiometric surface for this study (fig. 1A). Wells GA and SJ-23-4 (SJ-23-4 was destroyed in 2014 to prepare for underground mining, Edward Epp, BHP Billiton, oral commun., 2014) are located $6.4 \mathrm{~km}$ and $9.6 \mathrm{~km} \mathrm{(4} \mathrm{mi} \mathrm{and} 6 \mathrm{mi}$ ), respectively, southeast of the Hogback monocline. The hydrograph (fig. 3) indicates that, from about 1980 through 2013, hydraulic head in the Kpc in these wells, located in the central part of the study area, declined between $33 \mathrm{~m}$ and $80 \mathrm{~m}$ (110 ft and $270 \mathrm{ft}$, figs. 3 and 4). Wells BDMKPC1 and LPMKPC1 are located less than $1.6 \mathrm{~km}$ (1 mi) from recharge areas along the Hogback monocline at the northern boundary of the study area (fig. $1 A$ ). The hydrograph (fig. 3) indicates that, over a similar period, heads in these wells declined from $55 \mathrm{~m}$ to more than $90 \mathrm{~m}$ (180 ft to more than $300 \mathrm{ft}$ ). The decline in hydraulic head at both locations is interpreted to be caused primarily by oil and gas pumping (observed throughout the study area during field visits) and possibly by mine dewatering. A secondary cause of hydraulic-head decline is by potentially reduced groundwater recharge because of prolonged drought since 2000.

Conversely, the Kpc hydraulic head at well KPC1, located at the SJGS (figs. 1A, 3, and 5) in the west-central part of the study area near the Kpc surface outcrop increased by $3 \mathrm{~m}$ (10 ft), from about 1,597 $\mathrm{m}$ to 1,600 $\mathrm{m}$ (5,239 ft to $5,248 \mathrm{ft}$ ) for the short period of record, indicating that Kpc groundwater at the western side of the study area is receiving recharge. The closest likely continuous source of recharge is the SJGS raw water storage pond (fig. 1B), which was constructed on the Kpc surficial outcrop south of the SJGS, receives and stores water from the San Juan River, and has an operational water-level elevation of about 1,609 m (5,280 ft; NMOSE, 2014d). Hydraulic head in the overlying alluvial system, represented by the hydrographs from nearby MW4 and QAL3 (fig. 1A, inset 1; fig. 5) is also sufficient to promote groundwater recharge to the Kpc in the vicinity of KPC1 (fig. 5). However, dissolved-solids concentrations 
measured from alluvial well QAL3, on average, are almost twice those measured at KPC1 (fig. 1A, inset 1; fig. 17A), indicating that groundwater at KPC1 and QAL3 are not in strong hydraulic communication. Metric Corporation (2006) found that water from the raw water storage pond contributes to groundwater at MW4 and although chloride is lower at MW4 than at KPC1, dissolved solids at MW4 are similar to dissolved solids measured in groundwater at KPC1 (fig. 17A). The disparities of these water-chemistry indicators suggest that alluvial groundwater is not the principal recharge source of Kpc groundwater at KPC1. The inference that the raw water storage pond may be recharging the Kpc in the vicinity of KPC1 will be strongly supported if KPC1 hydraulic heads stabilize at or below (accounting for head losses) the water level of the raw water storage pond, and if concentrations of water-chemistry indicators remain static or decrease.

The Kpc wells installed at the SJM during 2011 provide sufficient potentiometric data to estimate the local Kpc horizontal flow direction at the SABR during the study period. Heads in Kpc SABR wells decrease from KPC2 to KPC5 to KPC4 (fig. 6) indicating that Kpc groundwater flow is generally eastward; however, water chemistry indicators at these wells vary substantially (fig. 17B), indicating that groundwater-flow paths in Kpc groundwater near the SABR are more complex than those assumed only by hydraulichead relations. This relation is persistent throughout the short period of record for the Kpc wells. Well KPC2 is overlain by Qal/Qnt, while KPC4 and KPC5 are both located north of and away from the Shumway Arroyo alluvium. Well KPC5 is overlain surficially by Kkf (Strobell and others, 1980) in a location where overlying Qal and Qnt are not present. Well KPC4 is located in a former surface mine pit and is overlain by mine spoil.

Approximately $1 \mathrm{~km}(0.6 \mathrm{mi})$ east of KPC5, within a reclaimed area, paired wells KPC3 and spoil monitoring well 7 (SM7, fig. 1A, inset 2) displayed a reversing hydraulic-head relation (fig. 7) indicating a transient reversal of the direction of potential vertical groundwater flux and also indicating that the Kpc acts as a competent aquitard in the vicinity of KPC3. The downward direction of the hydraulic-head gradient (from high to low) observed during 2011 reversed during the summer of 2012 and remained upward through the rest of the monitoring period. The absolute difference in hydraulic head at the two wells ranges between $0.18 \mathrm{~m}$ and $0.66 \mathrm{~m}(0.58 \mathrm{ft}$ and more than $2 \mathrm{ft}$ ), and the measurement error of these paired data does not exceed about $0.03 \mathrm{~m}(0.1 \mathrm{ft})$ and generally was about $0.014 \mathrm{~m}$ (0.045 ft; Taylor, 1997; Stewart and Thomas, 2015), indicating that the observed reversal of the hydraulic gradient is outside the range of possible measurement error. The KPC4 and KPC5 hydrographs follow the KPC2 (fig. 6) and SM7 hydrographs (fig. 7), while the KPC3 hydrograph (fig. 7) does not. This is interpreted to indicate that Kpc groundwater in the vicinity of the SABR may be subject to evapotranspiration and groundwater recharge stresses that are similar to those exhibited in hydrographs of shallow groundwater-system wells.
A review of driller's logs indicates that at KPC2, KPC4, and KPC5, Kpc groundwater may be either confined or semiconfined, whereas shallow groundwater at Qal/Qnt wells is considered to be unconfined (under water table conditions; Norwest Corporation, 2012). However, some SA wells that are nominally identified as having been completed in the Qal/Qnt appear to be cross-completed between the alluvium and the underlying formation, which, in most cases, is identified as the Kf. (SA wells are generally located adjacent to the present location of the SA channel. No driller's logs located for this review were located within the entrenched SABR channel.) However, the driller's log for KPC2 indicates that while the completion was in the Kpc, the Kpc at that location is overlain by Qal/Qnt. Wells GE and SA7 were cross-completed in Qal/Qnt and either the Kf or Kpc (Norwest Corporation, 2012; USGS, 2017b). The GL driller's report was not located although some anecdotal and tabulated data were found (USGS, 2017b). In general, driller's logs located at the time of writing indicate there is potential intermingling of groundwater between units along the SABR Qal/Qnt base.

Hydrograph comparisons indicate that shallow Kpc groundwater may also be hydraulically connected to groundwater in the mine-spoil fill toward the east, whereas the Kpc groundwater beneath the mine-spoil fill is likely responding to different hydraulic stresses that are unknown and unidentified, but may be related to the underground mine dewatering schedule.

\section{Number 8 Coal and Kirtland-Fruitland (Undifferentiated) Groundwater}

The Kkf groundwater-potentiometric maps were not constructed because of a lack of groundwater observation wells in the central and southeastern parts of the study area. Few Kkf regional groundwater monitoring wells were available for measuring depth to water for this study. Only two wells with long-term periods of record are known to exist east of and distant from the Hogback monocline and the $\mathrm{SJM}$, one groundwater well completed in the Kkf overburden and one well completed in the Kfn8 (fig. 1A, SJ-24-4 and SJ-13-2, respectively); SJ-24-4 was abandoned in 2014, and SJ-13-2 is planned for abandonment in 2018 in preparation for underground mining (Edward Epp, BHP Billiton, oral commun., 2014). At the SJM, wells G3, G26, and KF1 are completed in the Kfn8. Wells SA1 and KF2 (formerly KF2 and KF2D, and in this report, SA1/KF2 and KF2/KF2D, respectively) are completed along the short part of the SA (upper) reach downgradient from and south of the Shumway diversion channel (figs. $1 A$ and $1 B$ ). SA3 (dry, similarly renamed and called SA3/KF3 in this report) is completed in the SA (upper) just upgradient from the Shumway diversion channel; these three wells are all completed in the Kf. Wells GC, GD, GE, and GL are likely cross completed in Qal/Qnt and Kf; for this reason, routine monitoring at GC was halted during the early 1980s. At the SJGS, several wells installed to monitor pond leakage likely are screened in Kf. 
Kaiser and others (1994), in the context of coal bed methane production in the Kf, constructed a regional-scale $\mathrm{Kf}$ potentiometric map by interpreting oil and gas well bottomhole and wellhead shut-in pressure data. Potentiometric interpretation by Kaiser and others (1994) indicates that the Kf regional groundwater system recharges along the northern margin of the central basin and discharges to the San Juan River alluvial groundwater system or by oil and gas well extraction, generally consistent with the conceptual models proposed by Stone and others (1983) and Kernodle (1996) for groundwater movement in the study area. In the present study area, Kaiser and others (1994) mapped the highest potentiometric elevations in the north at land surface elevations of 1,890 m (6,200 ft), and the lowest potentiometric elevations near the San Juan River, at land surface elevations less than 1,585 m (5,200 ft). It was hypothesized by Kaiser and others (1994) that the Kf bears water mainly in coal beds, noting that in places north and northeast of the study area the larger permeability of the coal beds compared to other parts of the Kf promotes groundwater recharge to the coal beds, and the Kf potentiometric surface may exceed land surface elevations. Toward the south (including the present study area), Kaiser and others hypothesized that the permeability of coal beds decreases and recharge to the coal seam(s) is reduced, yielding a $\mathrm{Kf}$ potentiometric surface that is below land surface. They attribute upward hydraulic gradients above the Kf coal-bed groundwater system to convective fluxes caused by coal-bed pinch outs.

Numerical modeling results by Kernodle (1996) yielded predevelopment steady-state equipotential lines for the Kkf and the Kpc that, in the vicinity of the study area, were similar in locations where both results were presented. This potentiometric configuration should generate horizontal flow, without any vertical flow component, in the Kkf and the Kpc except near recharge and discharge areas. Predevelopment Kkf groundwater-flow directions are expected to be generally southerly and westerly from highland areas to discharge areas into the lower La Plata and San Juan River alluvial systems (Kernodle, 1996); postdevelopment Kf and Kfn8 groundwater is expected to flow toward oil and gas well pumping centers.

The Kkf and Kpc long-term hydrographs are shown in figure 4. Period-of-record and associated depth-to-water data collected prior to this hydrologic assessment for wells in the study area are provided in Stewart and Thomas (2015). Hydrographs from wells SJ-13-2 and SJ-23-4 (2.4 km [1.5 mi] apart; fig. $1 A$ ) display large declines in water levels (fig. 4) attributed in this report to regional drawdown from oil and gas well pumping; the large-amplitude late-time oscillations that occur after 2010 are better documented in the SJ-23-4 hydrograph than in the SJ-13-2 hydrograph, and may be because of nearby oil and gas well pumping or mine dewatering. Assuming that completions of SJ-23-4 in the Kpc and SJ-13-2 in the Kfn8 were designated correctly (Beach and Jentgen, 1978; Myers and Villanueva, 1986), it is notable that both hydrographs indicate declining hydraulic-head elevations that correlate temporally, albeit with about 3 years of lag at Kpc well SJ-23-4 (fig. 4). Between 1980 and 2000, hydraulichead elevations in the Kfn8 well SJ-13-2 were greater than or equal to head elevations in the Kpc well SJ-23-4 (fig. 4); after 2000, hydraulic-head elevations dropped in both wells, likely in response to the same nearby dewatering stresses. (Specific and detailed identification of the pumping oil and gas well that generated this groundwater stress was beyond the scope of this project.) The hydrograph from SJ-24-4, located about $1.6 \mathrm{~km}$ (1.0 mi) south of SJ-13-2 and completed in Kkf overburden, displays a decline of $4.25 \mathrm{~m}$ (about $14 \mathrm{ft}$ ) in hydraulic head during the period of record (fig. 4), indicating that the water-bearing zone in which it is completed is likely not hydraulically connected to regional dewatering mechanisms.

Well G3 is completed in undisturbed Kfn8 at the northern part of SJM, east of the former surface-mine pit high-wall terminus. The G3 hydrograph (fig. 8) indicates that declining hydraulic heads, attributed to surface-mine dewatering (as described in NMOSE, 2014c) that began to recover as early as 1999, is likely in response to the cessation of surface mining. Well G26, also completed in undisturbed Kfn8, is located on a terrace above the San Juan River Valley, about 1,500 m (5,000 ft) north of the San Juan River and of a known Kfn8 subcrop mapped at the riverbed (Mining and Minerals Division of New Mexico Energy, Minerals and Natural Resources Dept., written commun., 2010). Parts of the Kfn8 outcrop, located west of the subcrop adjacent to San Juan River alluvium, are likely unconfined and may provide a recharge source to the Kfn8. At well G26, Kfn8 groundwater is confined and 2013 water levels were measured at about $10 \mathrm{~m}$ (35 ft) above the top of the Kfn8 (lithology at G26 from MMD, 2017b). Hydraulic heads at G26 are plotted on the right axis to compare recovery trends with those at G3 (fig. 8). Hydraulic heads at G26 are always lower than hydraulic heads at G3, confirming regionally that Kfn8 groundwater flows from highland areas toward the San Juan River in accordance with the general conceptualization of flow. The few pre2002 data points from the G26 hydrograph (fig. 8) indicate that Kfn8 groundwater decline and recovery observed in the G3 hydrograph was also observed at G26. Conversely, after 2005, G26 hydraulic heads display uniform seasonal lags in oscillation and are slightly higher in elevation than nearby San Juan River stages, suggesting that the seasonal oscillations may be related to groundwater recharge associated with a standard irrigation schedule. These data, taken in combination, indicate that the Kfn8 coal seam in the vicinity of G26 may be variably recharged by regional Kfn8 groundwater and by local raw water irrigation inputs from Kfn8 unidentified outcrop areas west of and updip from G26 (MMD, 2017b, appendix 804.E). Most hydraulic heads measured at G26 during the hydrograph period of record have been greater than the elevation of the Kfn8 subcrop contact with the San Juan River; however, given the data gap in the G26 time series (fig. 8), the potential for recharge from the San Juan River to the Kfn8 at G26 cannot be completely excluded. 
Figure 9 (note differently scaled axes) shows hydrographs for alluvial well GC and for Kkf paired wells KF2/KF2D and $\mathrm{SA} 1 / \mathrm{KF} 2$. (KF2/KF2D is completed $10 \mathrm{~m}$ [32 ft] deeper than SA1/KF2; both well names were changed by SJM midway through the study, and references to these wells may be found under either name [with some confusion between the two wells observed in various databases].) Well GC is screened across the Shumway Arroyo alluvium and the underlying $\mathrm{Kf}$ and is located adjacent to the SA (upper) $1,550 \mathrm{~m} \mathrm{(5,100} \mathrm{ft)}$ upgradient from the Shumway Diversion Channel (figs. $1 A$ and $1 B$ ). No hydrograph for a fourth Shumway Arroyo well, SA3/KF3, located just upgradient from the Shumway Diversion Channel and completed west of the Shumway Arroyo in the Kf was included in figure 9 because the well has been dry since it was constructed in 2011.

The Kf paired wells KF2/KF2D and SA1/KF2 are located adjacent to the SA (upper). Although this reach of the SA (upper) is present, it presumably does not receive runoff from ephemeral flow events because runoff is diverted upstream at the Shumway Diversion Channel. These wells are just north of and upgradient from a reclaimed surface mining pit that is filled with mine spoil and CCB ash, where well SM5 is installed. Hydrograph peaks and troughs for these paired Kkf wells track similarly and display similar amplitudes (fig. 9). Notably, the SA1/KF2 and KF2/KF2D hydrographs do not correlate temporally with the GC hydrograph (note that the GC hydrograph is plotted at a different scale, thus amplitude signals do not correlate with the Kkf wells). The GC hydrograph displays a monsoon-season (summer) recharge signal, as evinced by the monsoon-season peaks. The peak observed in December 2013 is included as a monsoonseason peak because it is the first measurement taken after a large monsoon-season rainfall-runoff event that occurred in September 2013. Hydrographs for SA1/KF2 and KF2/KF2D display small peaks that lag the GC annual recharge peaks by about 6-8 months (fig. 9). These lags may indicate that Kkf groundwater present below the Qal/Qnt of ephemeral stream channels is recharged by ephemeral runoff events. This interpretation may be either supported or discarded as more hydraulic-head data become available, providing that monitoring of groundwater levels at GC is continued. The SA1/KF2 and KF2/KF2D hydrographs also document that hydraulic heads have usually been higher in SA1/KF2 than in KF2/KF2D indicating that the vertical groundwater hydraulichead gradient (from high to low) is usually downward at these paired wells. The hydrograph at spoil-monitoring well SM5 is shown with the two Kf hydrographs in figure 10 to demonstrate that the hydrograph signals are similar in amplitude and general trends, particularly after mid-2012. Well SM5 is located in the reclaimed surface-mined pit along the course of the SA (undermined). Similarity in the hydrograph signals indicates that the ephemeral flows that possibly provide recharge to groundwater at well GC and at the wells in the $\mathrm{Kf}$ may be the source of groundwater in the reclaimed pit. The water-table elevation at SM5 was about

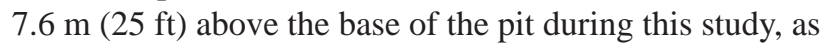

estimated by comparing groundwater levels with pit-bottom elevations at the SM5 location.

At the SABR, well SA6 is screened at the base of the Kf in carbonaceous siltstone. The SA6 hydrograph signal (fig. 13) displays similarity with evapotranspiration signals observed in hydrographs of nearby Qal wells, except that groundwater at that location is present in the $\mathrm{Kf}$ and is not present in the Qal. During the summer of 2012, water levels at that location declined at least $1.0 \mathrm{~m}$ (3.2 ft) but subsequently recovered. Nearby well SA4 was also completed and screened in the Kf; however, it was completed at a shallower depth than SA6 and was dry throughout the study period.

For this project, no wells in the TKoa, TKa, or Tn were located for measuring water levels. Following the approach of Kernodle (1996), and because the TKoa, TKa, and Tn were present in parts of the study area distant from CCB (ash) storage pits, and because the thickness of these units was small in the study area, these hydrostratigraphic units were lumped with the Kkf and assessed as an area of enhanced groundwater recharge to the Kkf in the numerical model developed for this report. Potentiometric surfaces, general flow direction, discharge, and hydraulic stresses were assumed to be represented by the lumped system.

\section{Quaternary and Shallow Groundwater System}

The shallow-alluvial water-table system flows from topographically higher areas toward topographically lower areas. Groundwater in shallow wells completed in Qal, Qal/ Qnt, in surficial Kkf and (or) surficial Kpc recharge areas, and in disturbed shallow surface areas is assumed to be under water-table conditions. In general, groundwater recharge to surficial water-bearing units, including Qal and Qnt, may occur from infiltration during runoff events and also may include contributions from underlying water-bearing units (Stone and others, 1983; Metric Corporation, 2007). Leaks from SJGS and SJM infrastructure, including watertransmission piping and process ponds, may also provide present-day groundwater recharge to surficial groundwater systems (Metric Corporation, 2007); however, with a few exceptions (discussed below in this section), the leakagelocation and repair-timing histories are generally unknown and were not considered in this hydrologic assessment.

Stone and others (1983) noted that the Shumway Arroyo system downgradient from the SJGS began to flow perennially following the installation of the SJGS. Conversely, workers of the now-defunct New Mexico Environmental Improvement Division noted that their review of aerial photographs indicated that the Shumway Arroyo flowed perennially at locations downgradient from irrigated farmland about $0.6 \mathrm{~km}$ $(0.4 \mathrm{mi})$ south of the SABR, along the SA (lower) (fig. $1 B$ ), prior to the installation of the SJGS (Raymondi and others, 1983).

Seepage from the raw water storage pond or related piping below the impoundment dam into a small arroyo tributary to the WWA (lower) has been measured at the rate of between $350 \mathrm{~m}^{3} / \mathrm{d}$ and $650 \mathrm{~m}^{3} / \mathrm{d}$ averaging $182.6 \times 10^{3} \mathrm{~m}^{3} / \mathrm{yr}$ 
(65 gallons per minute [gal/min] and $120 \mathrm{gal} / \mathrm{min}$, averaging 148 acre-ft/yr; NMOSE, 2014c).

Metric Corporation (2003, 2007), Luther and others (2005), and MMD (2017b), in various reports of the results of the same aquifer tests, noted that the saturated hydraulic conductivity of Qnt (Qal/Qnt) is $4.4 \mathrm{~m} / \mathrm{d}(14.5 \mathrm{ft} / \mathrm{d})$ in ephemeral stream channels in the study area. Stone and others (1983) reported that the transmissivities of Qal in ephemeral stream channels ranged from less than $93 \mathrm{~m}^{2} / \mathrm{d}\left(1,000 \mathrm{ft}^{2} / \mathrm{d}\right)$ in ephemeral stream channels to as much as $3,720 \mathrm{~m}^{2} / \mathrm{d}$ $\left(40,000 \mathrm{ft}^{2} / \mathrm{d}\right)$ in major drainages (table 3$)$. In the study area, shallow groundwater in the Qal/Qnt alluvial system discharges to the shallow Qal systems of the San Juan and La Plata Rivers.

Hydrographs for wells used to monitor the shallow Qal/ Qnt groundwater system in the vicinity of the SJGS and SJM are shown in figure 11 (some water-level periods of record are partial); water-level elevation data collected between February 26 and March 1, 2013, were used to contour watertable surface contours of the alluvial groundwater system (fig. 12; Stewart and Thomas, 2015). As expected, the shallow groundwater system flows from topographically higher areas toward topographically lower areas.

A comparison of shallow-well hydrographs (fig. 11) illustrates that hydrograph amplitudes for shallow groundwater wells were small in all but one case (QAL4), and that similarity between hydrographs increases with proximity of wells to each other or with proximity to similar recharge sources, such as process ponds or ephemeral stream channels. Although the hydrographs are relatively flat at the plotting scale, hydrographs at adjacent well locations (fig. 1A), with minor exceptions, do not cross (fig. 12), which would indicate a reversal of groundwater-flow direction between the two wells, and the potentiometric surface drawn for February 2013 (fig. 12) can be taken as a general representation of groundwater-flow patterns of the shallow system throughout the 2010-13 hydrologic assessment. Exceptions include the crossing of the CB1 hydrograph with the GD hydrograph in March 2011 and again in May 2012 and the crossing of the QAL1 hydrograph with the WWA1 hydrograph in April 2013. Transient hydrograph crossings may indicate either transient episodes of groundwater stagnation or short-term groundwater-flow direction reversals between two adjacent wells.

The following discussion describes groundwater flow through the shallow alluvial system as depicted in the watertable surface-contour map (fig. 12) in the context of associated hydrographs (fig. 11). It is important to note that many of the hydrographs shown in figure 11 represent groundwater conditions at wells that were installed to monitor potential effects to the surficial groundwater system from industrial activities at the SJGS. The following discussion describes some of the known effects to water quality of the shallow groundwater system in the vicinity of SJM in the context of identifying groundwater-flow-field characteristics. It is important to note that it was outside the scope of this project to generally identify or describe effects to groundwater quality of industrial processes at SJGS and SJM. The purpose of the following discussion is either to identify, if possible, postmining flow-field characteristics that will control groundwater-flow paths after industrial activities at the site have ceased or to suggest additional data that could be collected in support of that identification.

At the SJGS and vicinity, SJGS wells NEP3, NEP4, M3.1, M3.2, M3.3, CB1, and CB2 monitor seepage to groundwater from the North Evaporation Pond (NEP wells), various small process-water storage ponds (monitored at and between M3 wells, fig. 1A, inset 1), coal stockpile-runoffcollection ponds (CB wells), and (or) stormwater-collection ponds (monitored at and west of CB wells, fig. 1A).

The SJGS wells QAL1 and QAL2 are located to monitor seepage to groundwater from constructed channels and potential leakage from the SJGS (Metric Corporation, 2007); QAL2 also monitors surface flows routed to stormwater-collection ponds that are also monitored at wells CB1 and CB2. Wells QAL3 and QAL4 are located to monitor groundwater, respectively, in disturbed (USGS, 1995) and potentially disturbed ephemeral stream channels west of and tributary to the Westwater Arroyo diversion channel or Shumway Arroyo diversion channel and are also sited to monitor potential leakage from the SJGS (Metric Corporation, 2007). The SJGS Well-QNT and the SJM well GD, downgradient from Well-QNT, are located to monitor groundwater at the WWA (upper) (fig. 1B) in, respectively, undisturbed and potentially disturbed areas. Although WellQNT is the most upgradient monitoring well completed in Westwater Arroyo Qal/Qnt, it is located at least $3 \mathrm{~m}(10 \mathrm{ft})$ potentiometrically downgradient from NEP4 (with respect to potentiometric data collected during the study period; fig. 11; fig. $1 A$, inset 1 ). The brines at the NEP with chloride concentrations reportedly as much as 266,000 milligrams per liter (mg/L) (Metric Corporation, 2006) cannot be excluded as potential contributors to concentrations of chemical constituents measured at Well-QNT and GD. Between 2011 and 2013, chloride increased in groundwater from WellQNT to concentrations greater than those observed at NEP3, NEP4, or recently in groundwater from well GD (fig. 17C). Interpretation and identification of possible flow paths between the NEP and the WWA (upper) were outside the scope of this assessment; however, the Metric Corporation (2007) assessed that the NEP leaked from "1986 to perhaps 1988 " by relating increases and decreases in water levels to the history of liner repairs of NEP. Metric Corporation went on to hypothesize that it can be determined that the NEP cells "no longer leak *** if the water level in the two monitoring wells continue to decline.” These findings suggest that the NEP may have leaked between 2010 and the end of data collection for this study, based on observed increases in NEP3 and NEP4 water levels after the Metric Corporation 2007 report was issued (fig. 11). Although throughout the study period (2010-13), only the easternmost NEP cell 3 (fig. 12) contained brine, NEP cells 1,2 , and 3 (figs. $1 A$ and 12 ) are known 
to have contained brine simultaneously in the past. NEP1, NEP2, and NEP5 are completed at no more than $2.9 \mathrm{~m}(9.5 \mathrm{ft})$ below land surface. These wells have been dry throughout their periods of record, indicating that seepage from the NEP into shallow underlying fill material (some amount of fill at and around the NEP is assumed to have been required during construction) has not been observed at these well locations. Wells NEP3 and NEP4 were completed along the southeastern and northeastern corners of the NEP cell 3, respectively, at about $11 \mathrm{~m}$ (35 ft) below land surface. Both monitor groundwater that is assumed to originate as leakage from the NEP. Assessment and documentation of potential leakage from the NEP is beyond the scope of this assessment; however, it is correspondingly important to note that leakage from the NEP has the potential of overprinting natural Qal/Qnt groundwater chemistry at Well-QNT, precluding the use of that well as a monitoring station for base-line water-quality conditions of groundwater beneath the WWA (upper). Emplacement of an additional Qnt well, sufficiently upgradient from the NEP in the WWA (upper) could, by definition, still allow collection and comparison of WWA background water chemistry data if such a well were located hydrologically upgradient from effects related to SJGS or mining disturbances.

Well-QNT and GD are completed topographically downgradient from reclaimed mined areas to the north and northeast. Between 2009 and 2013, water levels at GD rose

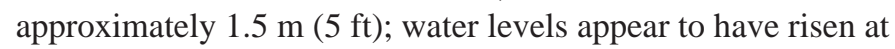
CB1 and CB2 during 2011-13, indicating that the horizontal hydraulic gradient and potential associated groundwater seepage between Well-QNT, GD, and the CB wells has decreased (fig. 11). Pre-2001 GD water-quality data may display effects of SJGS releases prior to 1983 (Williams, 1981; Phillips, 1982; EPA, 2011). During the present study, chloride was lower at NEP3 and NEP4 than at Well-QNT and GD, whereas dissolved solids at NEP3, NEP4, Well-QNT, and GD (fig. 17C; table 4) were similar in range from 10,433 to $19,189 \mathrm{mg} / \mathrm{L}$. These data may indicate that groundwater chemistry at Well-QNT is not uniquely described by NEP groundwater chemistry nor is it the sole influence of water chemistry at GD; it is also possible that sources of waterchemistry indicators between these two monitoring locations have changed over time (fig. 17C).

To the south at the SJGS, wells M3.1, M3.2, and M3.3 monitor possible SJGS process pond leakage. Groundwater levels in these wells display downslope hydraulichead gradients (fig. 11) and increasing recent-average concentrations of dissolved solids and chloride concentrations with proximity to the SJGS process pond (table 4) indicative of easterly flow (fig. 1A, inset 1) toward QAL2, (located along the bed of a predevelopment ephemeral channel that has undergone alteration). At QAL2, recent-average concentrations of dissolved solids and chloride (table 4) are smaller than at M3.3. From M3.3, the groundwater-flow direction is possibly towards wells CB1 and CB2 where recent-average concentrations of dissolved solids are smaller than at QAL2, and recent-average concentrations of chloride are either similar or slightly greater than at QAL2 (fig. 1A, inset 1 ; table 4), likely indicating that characteristics of water stored in and seeped from the CB pond has changed over time. From wells CB1 and CB2, WWA (detached) wells WWA2, WWA1, spoil monitoring well 16 (SM16) and the nearby temporary piezometer (JP2), and SM6 are located successively downgradient (fig. 12; Stewart and Thomas, 2015). Hydrographs for WWA1 and WWA2 track very closely with those of the CB wells, and average concentrations of dissolved solids and chloride are similar to those of CB1 (fig. 11; table 4). Hydrographs for SM16, JP2, and SM6 and chemical constituents are broadly more similar to hydrographs and chemical constituents observed at NEP4 and Well-QNT during the study period (fig. 11; table 4).

Toward the southwest, SJGS well MW4 (fig. 1A, inset 1 ) is located adjacent to and north of Duck Pond Arroyo (fig. $1 B$ ), and is likely cross completed in Qal and Kpc. As described in the "Groundwater Occurrence" section "Pictured Cliffs Sandstone Groundwater," groundwater near MW4 may be recharged by Kpc groundwater seeping from the raw water storage pond. The Duck Pond Arroyo (fig. 1B) and other ephemeral ponds were depicted in the 1963 "Waterflow" topographic quadrangle map (USGS, 1963), indicating that some ponds were present prior to construction of the SJGS.

The MW4 hydrograph tracks with that of QAL3 but not with the KPC1 hydrograph (fig. 5), whereas dissolvedsolids and chloride concentrations at QAL3 are more similar to those observed at KPC1 than at MW4 (fig. 17A). Metric Corporation (2006) analyzed groundwater at SJGS and found that groundwater at MW4 contains some contribution from the raw water pond, which accounts for some of these disparities.

Well QAL4 is located $300 \mathrm{~m}(1,000 \mathrm{ft})$ downgradient from the Duck Pond Arroyo in a fairly undisturbed location adjacent to glacial outwash deposits. The QAL4 hydrograph (fig. 11) displays the strongest observed evapotranspiration signal of study area hydrographs, evinced as a sinusoidal wave with an annual period, an amplitude of almost $1 \mathrm{~m}$ ( $3 \mathrm{ft}$ ), and with minimum values during the growing season and maximum values during the winter. (No known pumping in the shallow alluvial system was identified nearby). The strong evapotranspiration signal overprints recharge and lesser evapotranspiration signals observed in hydrographs of shallow wells elsewhere in the alluvial system (fig. 11).

Well SM6, completed in a reclamation area, is located $1.8 \mathrm{~km}(1.1 \mathrm{mi})$ south-southeast of Well-QNT just east of the WWA (detached). Well SM7 is located $1.8 \mathrm{~km}(1.1 \mathrm{mi})$ southeast of SM6 and $3.6 \mathrm{~km}$ (2.2 mi) southeast of WellQNT in a reclamation area. Despite these large distances, hydrographs at Well-QNT, SM6, and SM7 track similarly and without lags, indicating that shallow groundwater in these areas undergoes similar recharge and evapotranspiration stresses (see figs. 14, 15, and 16, respectively, for comparisons between Well-QNT and SM6 hydrographs, Well-QNT and SM7 hydrographs, and SM6 and SM7 hydrographs). Notably, Well-QNT is completed in Qal/Qnt while SM6 and SM7 are completed in mine spoil related to reclamation of former 
surface-mined areas. The SM7 hydrograph is included on figure 13, allowing similar comparisons to be made with SABR Kpc and Qal/Qnt hydrographs.

East of QAL4 and east of the WWA (upper), along the SA (upper) upgradient from mining activities and of the Shumway diversion channel, the GC hydrograph displays a signal inferred to result from monsoon-season ephemeral flows (fig. 9, discussed in the section entitled "Number 8 Coal and Kirtland-Fruitland (Undifferentiated) Groundwater").

Along the WWA (lower), the SJGS RTW (well) cluster was installed in response to the findings by Metric Corporation (2007) that SJGS industrial processes likely contribute some leakage to Westwater Arroyo alluvial groundwater. The pumping of the dewatering well produces a small cone of depression into which Qal/Qnt groundwater is drawn. Pumped groundwater is returned to SJGS process ponds to be treated by evaporation. During the study period, the recent-average dissolved-solids concentration at the RTW pumping well was 28,033 $\mathrm{mg} / \mathrm{L}$, and the recent-average chloride concentration was 3,520 mg/L (table 4).

Downgradient from the RTW well cluster, $120 \mathrm{~m}$ (400 ft) north-northwest of the former confluence of the Shumway and Westwater Arroyos along the WWA (lower), wells WWA3 and WWA3S were constructed at the contact of the Kpc and Qal/Qnt during 2012 and destroyed within a year. From the WWA3 well, where water-level elevations averaged $1,570.16 \mathrm{~m}$ (5,151.43 ft; fig. 11), hydraulic heads presumably continue to decrease to the southwest along SA (lower), near the outlet to the San Juan River, where the average waterlevel elevation at twinned wells E.Piez. and W.Piez. (2012 and 2013) was 1,559.58 m (5,116.74 ft) (Stewart and Thomas, 2015). Water-level elevations also decrease slightly (fig. 11) from the WWA3 wells along the up-dipping SABR from west to east in shallow wells, from GE (cross completed in Qal/Qnt and underlying sandstone) to SA7 (cross completed in Qal/Qnt and underlying Kf), and from there to GL (cross completed in the Qal/Qnt and underlying unit, believed to be Kf; fig. 13). A comparison of GE and GL potentiometric relations (fig. 13) indicates that for the period of this study, hydraulic heads were always higher in elevation at GE than GL, indicating that the groundwater-flow direction between these two wells was always easterly along the SABR. This relation was generally true throughout their entire periods of record with some exceptions (shown in fig. 11 from 2006 but also present earlier, not shown). Well SA4 (completed in Qal/ Qnt) has been dry through the period of record, whereas the hydrograph for nearby well SA6 (completed in the basal Kf) displays more variability and reversing head relations than hydrographs observed at the other shallow SABR wells. Wells SA4 and SA6 are located just inside the SJM lease area, just west of surface-mined areas reclaimed with mine spoil and CCB ash. The SABR hydrographs for wells completed in the shallow alluvial system (SA6, SA7; fig. 11; table 1) show evidence of evapotranspiration between 2011 and 2014 that is also weakly present in hydrographs from wells KPC4 and KPC5. Furthermore, hydrographs along the WWA (upper), the WWA (detached), and reclaimed areas east of the SABR, respectively, Well-QNT, SM6, and SM7 (figs. 14-16) also display strong similarities such as similar amplitudes, peaks, and troughs with generally little to no lag at SM7. The SM7 hydrograph also shares similarities with shallow SABR KPC4 and KPC5 hydrographs (fig. 13). The SM7 hydrograph is very dissimilar to the KPC3 hydrograph (fig. 7) although SM7 and KPC3 are twinned (located adjacent to each other; table 1). Similarities of hydrograph characteristics in these shallow wells indicate that the shallow groundwater system along the western part of the study area, including areas in the vicinity of the SABR, are subject to similar evapotranspiration losses and groundwater recharge gains in the shallow Kpc, in the Qal/Qnt along the SABR, and in reclaimed surface-mined pits.

Recent-average dissolved-solids and chloride concentrations for WWA3 were 12,475 mg/L and 1,150 mg/L, respectively (table 4) and increase toward the east in Qal/Qnt groundwater, supporting the conclusions of Phillips (1982), who studied the geochemistry of the SABR and attributed the easterly increase of salinity to "evapotranspiritive concentration" of naturally occurring groundwater constituents in combination with long residence times caused by the very shallow hydraulic gradient along the reach. Concentrations of chemical constituents at wells GE and GL (fig. $1 A$, inset 2) are shown in side-by-side time series plots (fig. 17B). The cause of asynchronous fluctuations in water chemistry for these two wells was not identified during the course of this hydrologic assessment.

Similarity in tracking of hydrographs from shallow SABR wells also allow the inference of vertical hydraulic connectivity across adjacent shallow water-bearing units including the Qal/Qnt, Kf, Kfn8, and Kpc (fig. 11). Well completion logs indicate that Qal and Qnt may be variously underlain by Kf and (or) Kpc (Metric Corporation, 1982; Norwest Corporation, 2012). Groundwater may flow vertically upward from the Kpc into Qal/Qnt at the KPC2/GL pairedwell location under an upward vertical hydraulic gradient of 0.00425, calculated with water levels measured on December 11, 2013 (Stewart and Thomas, 2015), with the flow length estimated from the centers of the well screens (table 1). Over their joint period of record, the hydrographs for wells GE and GL track together between 1989 and 1990 and between 1993 and 1997 but at other times display much less similarity (Stewart and Thomas, 2015). The lack of correlation may be attributed to measurement error, to spatial and temporal inversions of horizontal and vertical hydraulic gradients along the SABR over time, or to otherwise unidentified hydraulic system characteristics that did not manifest during the present study.

The SM7 hydrograph tracks with the SABR shallow groundwater-system hydrographs (fig. 6, fig. 7 [with the KPC3 hydrograph that does not track similarly as discussed in the "Groundwater Occurrence" section for Pictured Cliffs Sandstone Groundwater], and fig. 11) and with the hydrographs from SM6 and Well-QNT (figs. 14-16). The similarities between shallow alluvial-system hydrographs 
and the SM7 hydrograph allow the inference that the WWA (lower) groundwater system is hydraulically connected with the reclaimed mined area east of the SABR (fig. 12B). (The WWA [lower] is that portion of the former Westwater Arroyo that is merged with the Shumway Arroyo diversion channel, fig. $1 B$, which flowed intermittently during the period of this hydrologic assessment). At SM8, located at the west end of the pit just east of the SABR (fig. 1A), the spoil-fill is dry; however, SM8 is screened at the base of the minespoil fill, above the likely position of a water-table surface, if present, during the period of this hydrologic assessment (fig. 12; see table 1 for screen location information; USGS 2017). The water-table surface along the postmining SABR (fig. 12B), subject to evapotranspiration, declines gradually with distance from the former confluence of the Shumway (lower) and Westwater (lower) Arroyos (fig. 1B). It is reasonable to infer that the Qal/Qnt contact with the underlying $\mathrm{Kf} / \mathrm{Kpc}$ of the SABR base likely dips upwardly from the former confluence toward SA6, in the premining upgradient direction of ephemeral flow. The SABR base dips upward toward the east whereas the former surfacemine pit dips downward toward the east. The SABR base is not mapped, but point elevations are inferred from driller's logs (USGS, 2017b). Contours of the pit floor are shown in figure $12 B$ (MMD, 2017b). It is reasonable to infer the presence of a ridge between the terminus of the SABR base and the reclaimed mine pit floor, although the exact location of this ridge is unknown. It is likely that SABR groundwater, present in Qal/Qnt, in Kf, and in Kpc, backs up behind this ridge until hydraulic heads are sufficient to promote horizontal groundwater flow into the reclaimed pit through either mine-spoil fill, the Kf, if present, or the underlying Kрс. This inference is supported by the similarity between SABR and SM7 hydrographs (fig. 13). Well SA6 is screened in the lower Kf and is sited at the lateral contact between Qal/Qnt and Kf, with likely groundwater sources in local Kf highland areas to the south, ephemeral flows through the WWA (lower), and potentially from the underlying Kрс. Well SA4, completed in Qal/Qnt, was sited near the former Shumway Arroyo channel with likely groundwater sources being WWA (lower) ephemeral flows (fig. 1A; USGS, 1963). However, groundwater was not present in SA4 during this hydrologic assessment, although it was observed in SA6. Groundwater is also present in the adjacent reclaimed surface mine pit where the Kf and Kfn8 are presumed to have been removed. The source of groundwater observed at SM5 at the north part of the same pit was inferred to be correlated to ephemeral flows in the WWA (lower) in the previous section. Groundwater was recovering in the reclaimed pit during the hydrologic analysis phase of this study. In the previous section, it was inferred using hydrograph comparisons that the source of the groundwater may be composed of groundwater from surficial groundwater systems adjacent to the pit that are possibly augmented by runoff and, where applicable, groundwater recharge from intermittent flow through adjacent ephemeral stream channels. However, the areal extent and continuity of groundwater recovery across the reclaimed pit was not determined during the hydrologic analysis phase of this study.

These findings, taken together, indicate that groundwater hydraulic-head levels in some parts of the reclaimed surface mine at the SJM, including areas where CCB ash has been stored, has already begun to recover. The major source of groundwater recharge to reclaimed areas can be inferred to be alluvial groundwater of variously disturbed ephemeral stream channels, recharged by focused runoff in ephemeral stream channels following precipitation events. Hydrologic data collected during this project also support the inference that groundwater in reclaimed areas is contributed from the underlying Kpc under the influence of upwardly vertical hydraulic gradients. During active mining, it is expected that upwardly vertical gradients likely change spatially and temporally in response to underground mine and oil and gas dewatering.

\section{Numerical Simulation of Groundwater Flow}

The purposes of numerical modeling were to (1) assess time to recovery of the premining steady state as determined by the steady-state model prepared for this project and to (2) identify groundwater-flow paths from CCB storage areas to downgradient alluvial systems. The following sections describe development of the numerical model and modeling results.

\section{Previous Numerical Modeling Investigations in the Study Area Vicinity}

A number of local- to regional-scale reports describe or characterize prior data-supported numerical-modeling projects cited in this report. Frenzel and Lyford (1982) simulated hydraulic-head conditions in Jurassic- through Late Cretaceous-age water-bearing units in the San Juan Basin. The Cretaceous-age Cliff House Sandstone and overlying Lewis Shale were the uppermost formations considered and are the basal units included in the present study. Their numerical modeling results (1982) indicate net upward groundwater flux through the Lewis Shale confining unit in the San Juan River part of the San Juan Basin to be about 8,100 m³ $\left(286 \times 103 \mathrm{ft}^{3} / \mathrm{d}\right)$.

Kernodle and Philip (1988) developed a geographic information system (GIS) based preprocessor and postprocessor for numerical modeling of the San Juan Basin. Kernodle (1996) reported results of associated steady-state numerical groundwater modeling using the modular finitedifference groundwater-flow model, MODFLOW (McDonald and Harbaugh, 1988). The Kernodle (1996) results were digitized and used to support and inform the numerical modeling that is the subject of this report because the digital 
product of that study was not archived and does not exist. Kernodle's potentiometric results for the Cretaceous KirtlandFruitland Formations (undifferentiated, and in some areas including overlying water-bearing units, also undifferentiated) and for the underlying Cretaceous Pictured Cliffs Sandstone are, at the presentation scale, vertically equivalent throughout the San Juan Basin except at recharge and discharge areas. This implies that groundwater in these water-bearing units flows horizontally except at locations of groundwater recharge or discharge.

To support a hydrologic assessment of the San Juan Basin in the context of coal bed methane extraction, Kaiser and others (1994) constructed a groundwater-flow model that conceptualized the Cretaceous Fruitland Formation shale beds and coal beds with the Pictured Cliffs Sandstone as a unified water-bearing zone. S.S. Papadopulos and Associates, Inc. (2006) contrasted the conceptual model of Kaiser and others (1994) with that of Riese and others (2005), which incorporates the assumption that the groundwater-flow systems contained in each unit are "highly compartmentalized.” S.S. Papadopulos and Associates, Inc. (2006) reviewed and compared both reports and noted that both conceptual models can be represented satisfactorily in the same model by adjusting model parameters assigned to the various units.

Cox and others (2001) modeled depletion of surfacewater flow in several perennially flowing rivers in response to Fruitland Formation dewatering or depressuring for coal bed methane extraction in southwestern Colorado (north of the present study area).

The San Juan Mine reported in their 2009 minepermitting documentation, in a document entitled "San Juan Mine Permit 04-01," that a MODFLOW model of the underground mine site had been prepared by Applied Hydrology Associates Inc. and used to "depict the hydrogeologic system at the San Juan Underground Mine and vicinity” (MMD, 2017b). The numerical model was used, for permitting purposes, to estimate potential underground mine dewatering and groundwater recovery rates. Results indicated that given the "completion of mining at the end of Year 2018 $* * *$ post-mining equilibrium conditions will be reached before year 2200" (MMD, 2017b; the model did not incorporate regional oil and gas dewatering).

Thomson and others (2012) tested samples of new and aged SJM CCBs to identify geophysical and leaching properties and to assess the potential for leaching of metals from CCB ash into groundwater. They used results to perform numerical modeling of unsaturated material representing covered storage pits containing CCBs. Thomson and others found that "the potential for contamination of the underlying regional aquifer $* * *$ is small," which they attributed to low saturated hydraulic conductivity of CCB storage-pit cover material, uptake of water in the unsaturated zone by evapotranspiration, and "low concentrations of contaminants in leachates from buried CCBs.”

\section{Conceptual Flow Model}

The term "conceptual flow model" describes an initial representation of the groundwater-flow system used to inform and develop a numerical model (Anderson and Woessner, 1992). A conceptual model qualitatively aids in assessing and summarizing groundwater fluxes into and out of the area of interest and in the context of the greater hydrologic setting. It provides a starting place for development of the numerical model and informs the systematic process of quantifying and constraining input variables. Values obtained from conceptual modeling are summarized in table 5 .

For the current study, previous works of Lyford (1979), Frenzel and Lyford (1982), Stone and others (1983), Kernodle (1996), and Craigg (2001) were used to develop a representation of the regional hydrostratigraphic framework (figs. $2 A$ and $2 B$ ) as a basis for model layers. The structure of the basin is believed to generate vertically upward hydraulic gradients that likely vary in strength throughout the basin interior. Most groundwater recharge is conceptualized as occurring at San Juan Basin highland areas, outside of the study area, where snowfall and associated snowmelt preferentially recharges regionally continuous water-bearing units that are older and deeper than water-bearing units included in this study. Within the study area, water-bearing units are conceptualized to be recharged mainly at Hogback areas as well as along perennially and ephemerally flowing stream channels. In the vicinity of SJM, very low diffuse-areal groundwater-recharge rates are expected because much of the surficial soil (except for Qal) is composed of Kkf shale that weathers to swelling clay-dominated soils (Thomson and others, 2012), limiting infiltration. Upwardly flowing groundwater is conceptualized to discharge to water-bearing units that subcrop along perennial streams and also to be lost to evapotranspiration. An areally apportioned estimate of the volume of upwardly flowing groundwater in the present study area of $170 \mathrm{~m}^{3} / \mathrm{d}\left(6,000 \mathrm{ft}^{3} / \mathrm{d}\right)$ was derived from the results of Frenzel and Lyford (1982; table 5). Estimates of potential evapotranspiration volumes have a very large range (table 5), which was considered qualitatively to constrain evapotranspiration rates.

In the study area, for modeling purposes, the central San Juan Basin is conceptualized to be hydrologically disconnected from surrounding water-bearing units of the San Juan Basin along the uplifted Hogback monocline (Craigg, 2001), the crest of which is Kch (Strobell and others, 1980; Green and Jones, 1997). Based on this conceptualization, the Kch was therefore selected as a hydrologic boundary for the west and north sides and bottom of the model domain. To the south, the model domain is bounded by the San Juan River, which was assumed to be a regional groundwater discharge feature. To the east, the model domain was bounded along a groundwater ridge present in the Kpc and Kkf steady-state numerical modeling results of Kernodle (1996) that was assumed to represent a zero-flux flow path that did not extend into the Kls or Kch. 
Table 5. San Juan Mine study area conceptual model: preliminary quantifications and conceptualizations for numerical modeling, San Juan, New Mexico.

[m, meter; GIS, geographic information system; $\mathrm{m}^{2}$, square meter; GWV, Groundwater Vistas; $\mathrm{m}^{3} / \mathrm{d}$, cubic meter per day; in/yr, inch per year; km² square kilometer; $\mathrm{mi}^{2}$, square mile; NEP, North Evaporation Pond; m/d, meter per day; m/yr, meter per year; cm, centimeter; ft/yr, foot per year; Kch, Cretaceous Cliff House Sandstone; Kls, Cretaceous Lewis Shale; ET, evapotranspiration; SJM, San Juan Mine; Kpc, Cretaceous Pictured Cliffs Sandstone; Kkf, Cretaceous Kirtland Shale/Fruitland Formation; DD1, first transient drawdown model; DD2, second transient drawdown model]

\begin{tabular}{|c|c|c|c|}
\hline Term & Value & Units & Sources \\
\hline $\begin{array}{l}\text { Thickness of San Juan River } \\
\text { alluvium (Qal) }\end{array}$ & as much as 31 & $\mathrm{~m}$ & Stone and others (1983) \\
\hline $\begin{array}{l}\text { Thickness of Naha and Tsegi } \\
\text { Formation (Qnt) }\end{array}$ & $6-9$ & $\mathrm{~m}$ & Metric Corporation (1982) \\
\hline $\begin{array}{l}\text { Thickness of the Cretaceous } \\
\text { Pictured Cliffs Sandstone (Kpc) }\end{array}$ & 37 & $\mathrm{~m}$ & Mining and Minerals Division (2017b) \\
\hline $\begin{array}{l}\text { Thickness of the Cretaceous Lewis } \\
\text { Shale (Kls) }\end{array}$ & variable & & Dubiel (2013) \\
\hline $\begin{array}{l}\text { Thickness of the Cliff House } \\
\text { Sandstone (Kch) }\end{array}$ & 100 & $\mathrm{~m}$ & Dane (1936); Fassett (1977); and Craigg (2001) \\
\hline $\begin{array}{l}\text { Area of Quaternary alluvium and } \\
\text { Naha and Tsegi Formation by } \\
\text { GWV }\end{array}$ & $8,100,000$ & $\mathrm{~m}^{2}$ & Area calculation of shape file in GIS \\
\hline $\begin{array}{l}\text { Area of Quaternary alluvium and } \\
\text { Naha and Tsegi Formation by } \\
\text { GWV }\end{array}$ & $25,500,000$ & $\mathrm{~m}^{2}$ & By GWV (using 102 active cells $\times 250,000 \mathrm{~m}^{2}$ ) \\
\hline
\end{tabular}

Groundwater recharge and evapotranspirational stresses

Daily diffuse areal recharge

Leakage from freshwater and north evaporation ponds (daily average)

Recharge to ephemeral stream channel alluvium from monsoon storms (daily average)

Irrigation inputs to areas adjacent to perennially flowing streams

Sum of four preceding entries (using maximum value for daily diffuse areal recharge)

Daily precipitation volume

Potential ET (note that MODFLOW modeling does not account for ET on the land surface or in the unsaturated zone)

85-5,346 $\mathrm{m}^{3} / \mathrm{d}$

$75 \quad \mathrm{~m}^{3} / \mathrm{d}$

$2,931 \quad \mathrm{~m}^{3} / \mathrm{d}$

$24,722 \quad \mathrm{~m}^{3} / \mathrm{d}$

$33,000 \quad \mathrm{~m}^{3} / \mathrm{d}$
Stone’s (1987) range of 0.002 to $0.09 \mathrm{in} / \mathrm{yr}$ at nearby study area (low end of range); Kernodle's (1996) average daily value of $0.125 \mathrm{in} / \mathrm{yr}$ (high end of range); multiplied by GIS-calculated area

For transient modeling only: assumes Darcian flow pond leakage estimated using average of Kpc vertical and horizontal hydraulic conductivity value of $2 \times 10^{-4} \mathrm{~m} / \mathrm{d}$ and an assumed gradient of 0.5 . Approach yields an estimate of $25 \mathrm{~m}^{3} / \mathrm{d}$ per $0.25-\mathrm{km}^{2}$ cell.

Assuming Darcian vertical flow using vertical saturated hydraulic conductivity of ephemeral stream channel alluvium of $0.04406 \mathrm{~m} / \mathrm{d}$ under a unit gradient (1), for 3 days per year over an area of $8.1 \mathrm{~km}^{2}$

Estimated as 10 percent of $1.52 \mathrm{~m} / \mathrm{yr}$ water applied on about 80 percent of area adjacent to perennially flowing streams $\left(59.25 \mathrm{~km}^{2}\right)$
$438,055 \quad \mathrm{~m}^{3} / \mathrm{d}$

$\begin{array}{rr}2,628,328 & \mathrm{~m}^{3} / \mathrm{d} \\ 1,516,010 & \mathrm{~m}^{3} / \mathrm{d} \\ 1,010,674 & \mathrm{~m}^{3} / \mathrm{d} \\ 438,055 & \mathrm{~m}^{3} / \mathrm{d}\end{array}$

Weighted daily values of Arguez and others (2010; 26.4 cm weighing Mesa Verde, Colorado, station data with 0.10 and Farmington and Fruitland, N. Mex., stations with 0.45 each) and GIS-calculated area Daily precipitation volume of Arguez and others (2010)×6, following Federal Coal Management Program (1979)

Federal Coal Management Program (1979) 3 ft/yr estimate with GIS area

Federal Coal Management Program (1979) 2 ft/yr estimate with GIS area

Evaluated as all estimated precipitation 
Table 5. San Juan Mine study area conceptual model: preliminary quantifications and conceptualizations for numerical modeling, San Juan, New Mexico.-Continued

[m, meter; GIS, geographic information system; $\mathrm{m}^{2}$, square meter; GWV, Groundwater Vistas; $\mathrm{m}^{3} / \mathrm{d}$, cubic meter per day; in/yr, inch per year; $\mathrm{km}{ }^{2}$, square kilometer; $\mathrm{mi}^{2}$, square mile; NEP, North Evaporation Pond; m/d, meter per day; m/yr, meter per year; cm, centimeter; ft/yr, foot per year; Kch, Cretaceous Cliff House Sandstone; Kls, Cretaceous Lewis Shale; ET, evapotranspiration; SJM, San Juan Mine; Kpc, Cretaceous Pictured Cliffs Sandstone; Kkf, Cretaceous Kirtland Shale/Fruitland Formation; DD1, first transient drawdown model; DD2, second transient drawdown model]

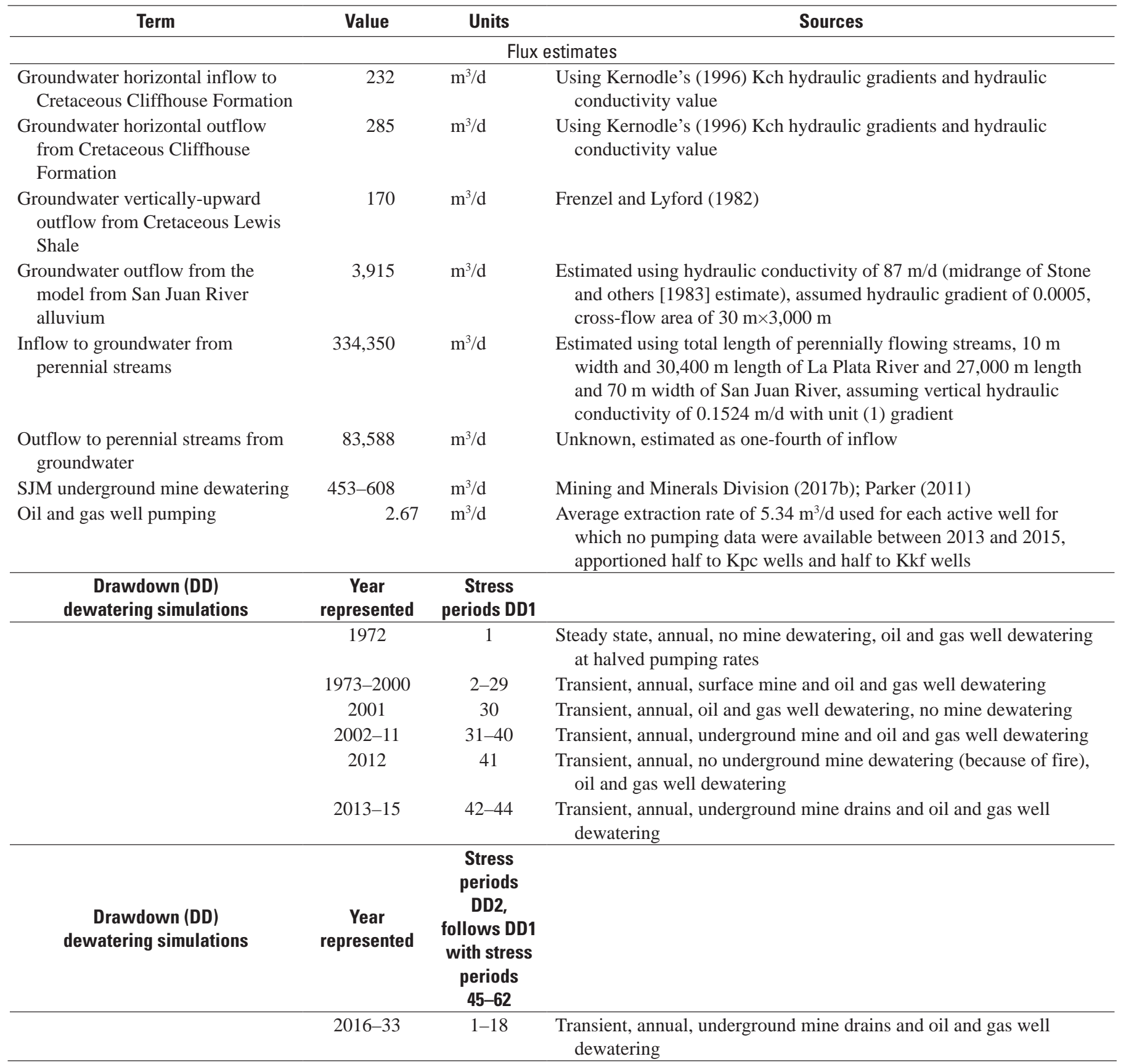


The Kch potentiometric surface in the vicinity of the SJM is conceptualized to be higher in elevation than potentiometric surfaces of overlying units, generating upward vertical head gradients expected to drive groundwater flux upward with the volumes of flux depending upon the aggregate vertical saturated hydraulic conductivities of the water-bearing units and the strength of the vertical hydraulic gradient. The hydraulic gradient generated by the Kch potentiometric surface to overlying water-bearing units was assumed to incorporate the aggregate hydraulic gradients of deeper underlying water-bearing units that were not included in the model domain. At the SJM, CCBs and interbedded mine spoil are stored in reclaimed surface-mining pits in locations where $\mathrm{Kfn} 8$ and overlying $\mathrm{Kf}$ and possibly $\mathrm{Kkf}$ were removed by mining. The potential for CCB storage pits to be subject to groundwater exchange with deeper units and with adjacent Qal/Qnt was, in this manner, incorporated into the conceptual model in accordance with results of the hydrologic assessment.

Potentiometric results of Kernodle (1996), with associated uncertainties, were used as a first-pass representation of predevelopment steady-state potentiometric configurations in the Kkf, Kpc, and the Kch. Kernodle (1996) did not model the alluvial groundwater system explicitly, rather in his model, grid cells containing "both aquifer outcrop and a stream segment" were treated according to a function describing surface-water and groundwater exchanges based on head differences. Kernodle's (1996) Kch potentiometric surface was greater than land surface elevation in the vicinity of the San Juan Mine; this numerical modeling result did not agree with the Kch potentiometric map provided by Stone and others (1983) nor did it agree with a single Kch depth-to-water measurement provided by Irwin (1966; table 3).

Regional groundwater conditions in the vicinity of the SJM lease area (fig. $1 A$ ) present during the hydrologic assessment phase of this project were assumed to generally reflect spatially and temporally varying conditions attributed to decades-long dewatering for surface and underground mining and oil and gas well pumping. Small-scale pumping and recharge stresses in the study area, such as possible domestic water-well use and small-scale irrigation in the San Juan and La Plata alluvial valleys and leakage from process ponds or water lines, which were of either shortterm or unidentifiable durations and locations, were ignored. Conversely, leakage from the unlined SJGS raw water storage pond was assumed to be constant throughout the operational period of the SJGS and was incorporated in transient-drawdown model simulations. The conceptualization of ongoing groundwater recharge and associated increased evapotranspiration resulting from irrigated agriculture in alluvial valleys near the San Juan and La Plata Rivers was incorporated in the model.

\section{Description of Numerical Flow Model: Development and Methods}

The USGS numerical modeling package MODFLOWNWT (Niswonger and others, 2011) was selected for this study for its capability in handling drying and rewetting of thin unconfined cells. MODFLOW-NWT is a stand-alone version of MODLFOW that solves the finite-difference formulation of the groundwater-flow equation with the XMD asymmetric-matrix solver (Niswonger and others, 2011) that was used for this project. MODFLOW-NWT requires standard MODFLOW packages (including basic [BAS], discretization [DIS], zone [ZONE], and output control [OC] packages) as well as the Newton solver package (NWT) and the Upstream-Weighting Package (UPW, required in MODFLOW-NWT to handle flow between model cells). Also used were the streamflow routing, general-head boundary, drain, and well boundary condition packages (SFR, GHB, DRN and WEL, respectively); the evapotranspiration and recharge stress packages (EVT and RCH, respectively); and the head-observation package (HOB), which was used to aid in model calibration.

Groundwater Vistas (GWV), a preprocessing and postprocessing software (Environmental Simulations Incorporated [ESI], 2014), was used to produce input files for MODFLOW-NWT, to transfer data to and from ArcMap GIS and Microsoft Excel, to prepare input files for particle tracking that was run using the GWV MODPATH 5.0 (Pollock, 1994) module, and to visualize model inputs and results of model trials. The 64-bit versions of MODFLOW-NWT versions 1.0.8 and 1.0.9 were used outside of GWV to perform model trials. Manual calibration trials were performed iteratively with automated calibration runs to assess model sensitivities and to improve calibration with respect to parameter, stress package, and boundary condition adjustments. Input and output files for the model are provided in an associated USGS data release (https://doi.org/10.5066/F75719JV, Stewart, 2018).

\section{Spatial and Temporal Discretization}

The groundwater-flow model was constructed using meter as the fundamental spatial unit and day as the fundamental time unit. The model grid was composed of 67 rows, 72 columns, and 6 layers and was discretized into uniform grid cells $500 \mathrm{~m}(1,640 \mathrm{ft})$ on a side $\left(0.25 \mathrm{~km}^{2}\right.$ or $0.1 \mathrm{mi}^{2}$ in area) (fig. 18). The model layers represent (from top to bottom, see tables 3, 6A, and 6B) Qal and Qnt (as Qal or Qal/Qnt, Layer 1); CCB repositories, Kkf, and where present, undifferentiated Kkf, TKoa, and TKa (Layer 2); Kfn8 and where present, CCB repositories and subsided overburden (Layer 3); Kpc (Layer 4); Kls (Layer 5) and Kch (Layer 6) (see fig. 18 for locations of model layers; additional information regarding parameter and boundary conditions for model layers can be found in figs. 19-27; a hydrostratigraphic cross section is shown in fig. 28). 


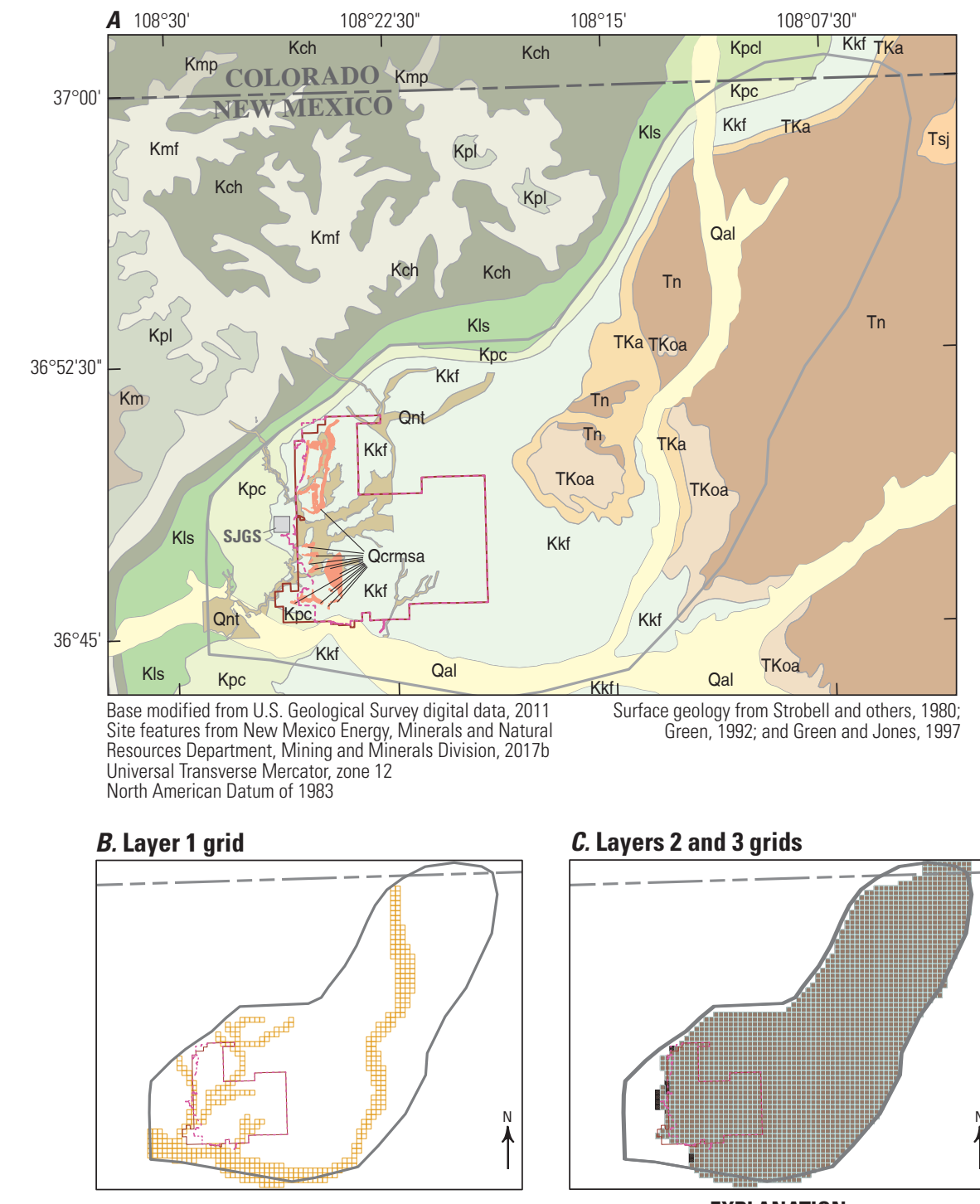

Layer $1 \quad$ Layer 2

\section{$108^{\circ} 15^{\prime}$}

$108^{\circ} 07^{\prime} 30^{\prime \prime}$

\section{Layers 2 and 3 grids}

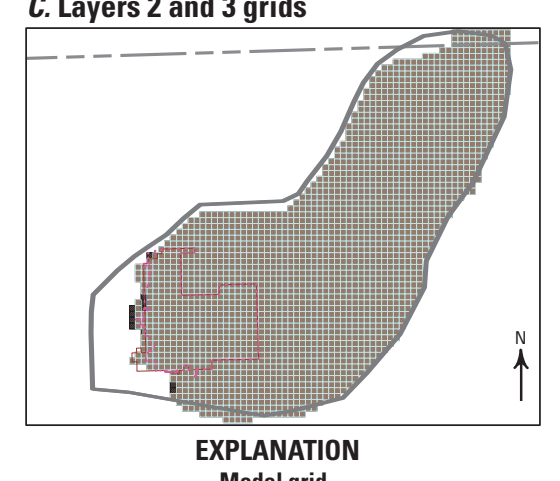

Model grid

Layer 3-Black hatch represents Cretaceous Fruitland Formation Number 8 coal seam where Kkf has eroded
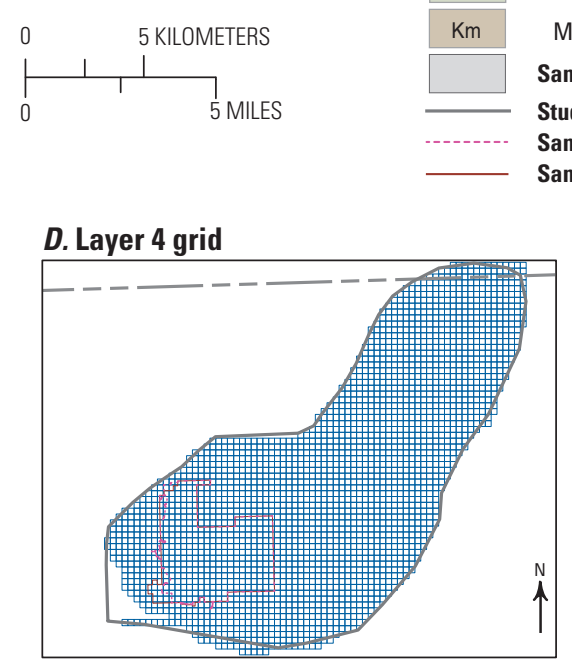

Layer 4 Layers 5 and 6 (undifferentiated) Model grid cells for layer 2 are coincident with layer 3 , except the westernmost columns where eroded

EXPLANATION

\section{Surface geology}

Alluvium

Naha and Tsegi eolian deposits (undifferentiated)

Ash, covered and reclaimed mine spoil

San Jose Formation

Nacimiento Formation-The Nacimiento Formation grades laterally into the upper part of the Animas Formation

0jo Alamo Sandstone

Animas Formation

Kirtland Shale and Fruitland Formation (undifferentiated)

Pictured Cliffs Sandstone

Pictured Cliffs Sandstone and Lewis Shale (in Colorado)

Lewis Shale

Cliff House Sandstone

Menefee Formation

Menefee Formation and Point Lookout Sandstone (in Colorado)

Point Lookout Sandstone

Mancos Shale

San Juan Generating Station (SJGS)

Study area boundary

San Juan Coal Mine permit area boundary

San Juan Coal Mine lease area boundary

\section{E. Layers 5 and 6 grids}

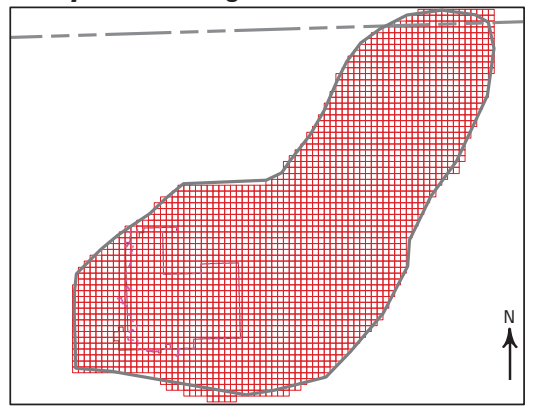

\begin{tabular}{lllll}
0 & 5 & 10 & 15 & 20 \\
\hline & KILOMETERS
\end{tabular}

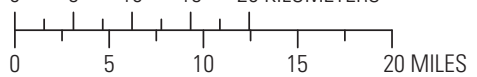


Model layer 1-Alluvium ( 0 al) and undifferentiated Naha and Tsegi eolian deposits (Qnt)

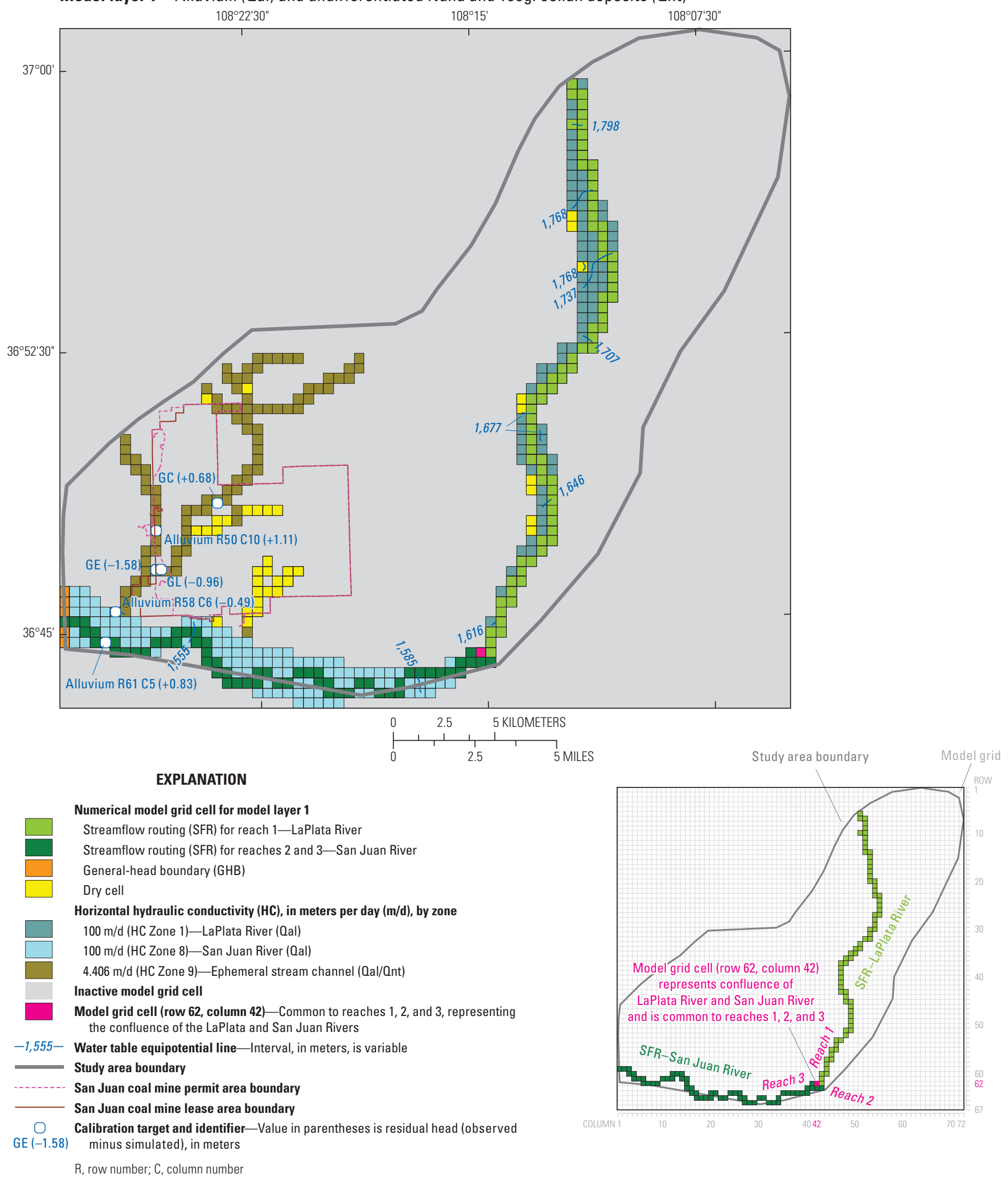

Figure 19. Layer 1 (alluvium) calibration targets and residuals, boundary conditions, calibrated horizontal hydraulic conductivity distribution (Zones 1, 8, and 9), inactive Layer 1 grid cells (Zone 12), and model grid row and column numbers. 
Model layer 2-Coal combustion byproduct (CCB) repositories; Cretaceous Kirtland Shale and Fruitland Formation, undifferentiated (Kkf); and where present, undifferentiated Kkf, Tertiary-Cretaceous Ojo Alamo Sandstone (TKoa), and Tertiary-Cretaceous Animas Formation (TKa)

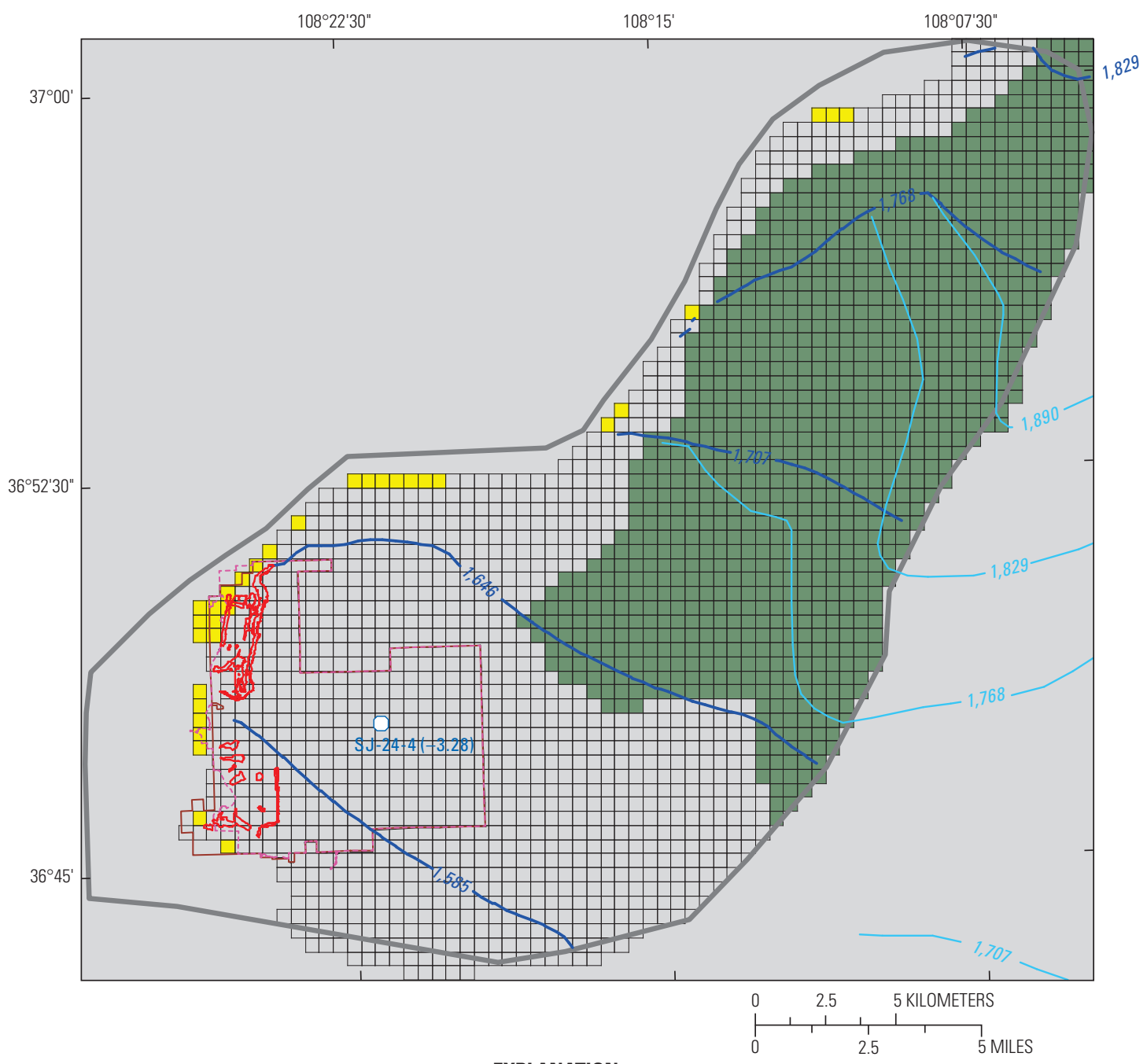

EXPLANATION

Numerical model grid cell for model layer 2

Dry cell

Horizontal hydraulic conductivity (HC), in meters per day (m/d), by zone

$3.048 \times 10^{-3} \mathrm{~m} / \mathrm{d}$ (HC Zone 2)

$3.048 \times 10^{-3} \mathrm{~m} / \mathrm{d}$ (HC Zone 7)

-1,646-Calibrated steady-state potentiometric contour-Shows elevation at which water level would have stood in tightly cased wells. Contour interval 61 meters. Datum is North American Vertical Datum of 1988 (NAVD 88)

-1,707- Numerical modeling potentiometric contour for Cretaceous Kirtland Shale and Fruitland Formation, undifferentiated and overlying formations (Kernodle, 1996) - Shows elevation at which water level would have stood in tightly cased wells, 1996. Contour interval 61 meters. Datum is NAVD 88

Study area boundary

San Juan coal mine permit area boundary

San Juan coal mine lease area boundary

Estimated boundary of CCB ash ( 0 crmsa) and mine-spoil deposits $(0 \mathrm{crms}$, mine spoil buried between and around CCB deposits

Calibration target and identifier-Value in parentheses is residual head (observed minus simulated), in meters Steady-state

Figure 20. Layer 2 (Cretaceous Fruitland Formation excluding mineable coal seams and including overlying units), calibration target and residual, calibrated hydraulic conductivity distribution (Zones 2 and 7) and calibrated steady-state potentiometric contours, Kernodle's (1996) Cretaceous Kirtland Shale/Fruitland Formation (undifferentiated) potentiometric results, and locations of coal combustion byproduct ash repositories. 
Model layer 3-Cretaceous Fruitland Formation number 8 (Kfn8) coal seam

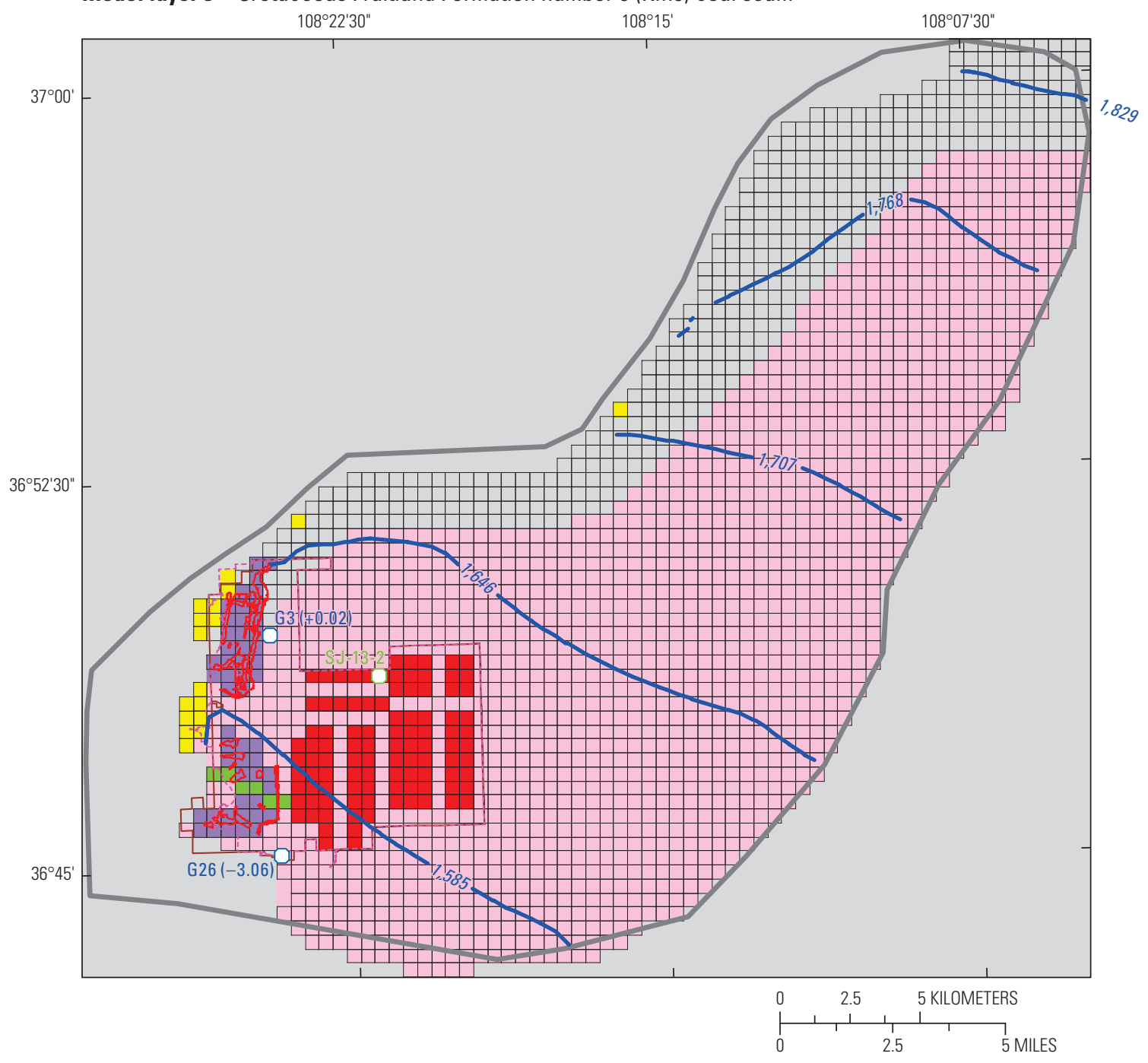

\section{EXPLANATION}

Numerical model grid cell for model layer 3

Dry cell

Horizontal hydraulic conductivity (HC), in meters per day $(\mathrm{m} / \mathrm{d})$, by zone

$6.096 \times 10^{-2} \mathrm{~m} / \mathrm{d}$ (HC Zone 3)

$3.048 \mathrm{~m} / \mathrm{d}$ (HC Zone 12)

$6.096 \times 10^{-2} \mathrm{~m} / \mathrm{d}$ (HC Zone 13

$7.344 \times 10^{-3} \mathrm{~m} / \mathrm{d}$ (HC Zone 14)

$3.048 \times 10^{-3} \mathrm{~m} / \mathrm{d}$ (HC Zone 15)

-1,646-Calibrated steady-state potentiometric contour-Shows elevation at which water level would have stood in tightly cased wells. Contour interval 61 meters. Datum is North American Vertical Datum of 1988

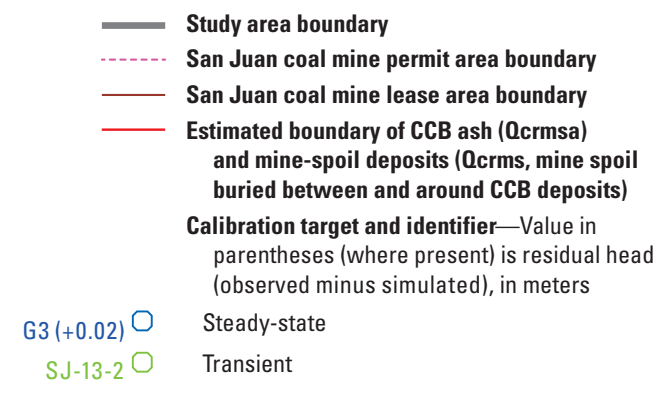

Figure 21. Layer 3 (Cretaceous Fruitland Formation Number 8 coal seam), calibration targets and residuals, post-mining hydraulic conductivity distribution (gob shown in red, HC Zone 15), calibrated steady-state potentiometric contours, and locations of coal combustion byproduct ash repositories. 


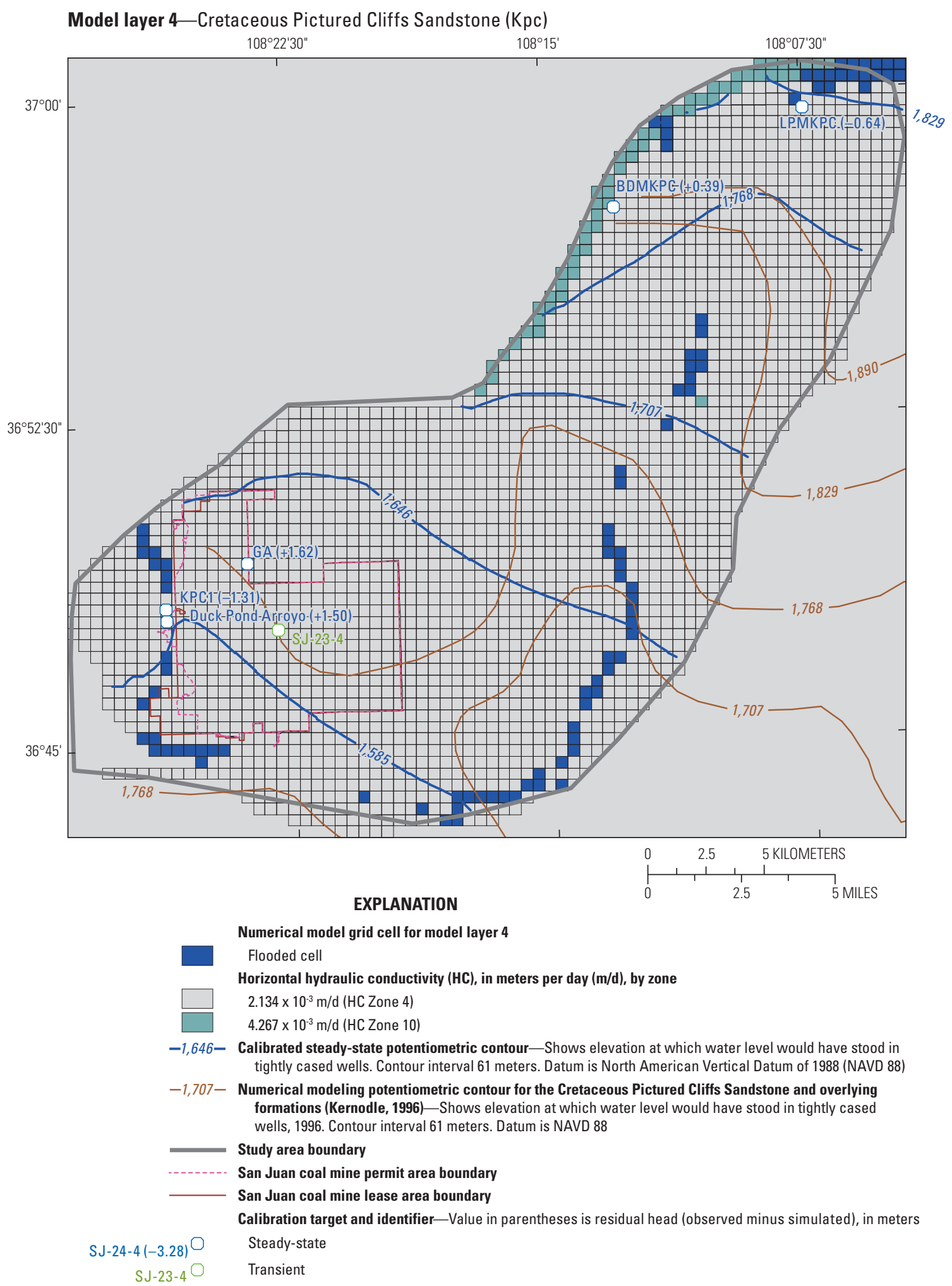

Figure 22. Layer 4 (Cretaceous Pictured Cliffs Sandstone [Kpc]), calibration targets and residuals, calibrated hydraulic conductivity distribution, and calibrated potentiometric contours with Kernodle's (1996) Kpc potentiometric results. 


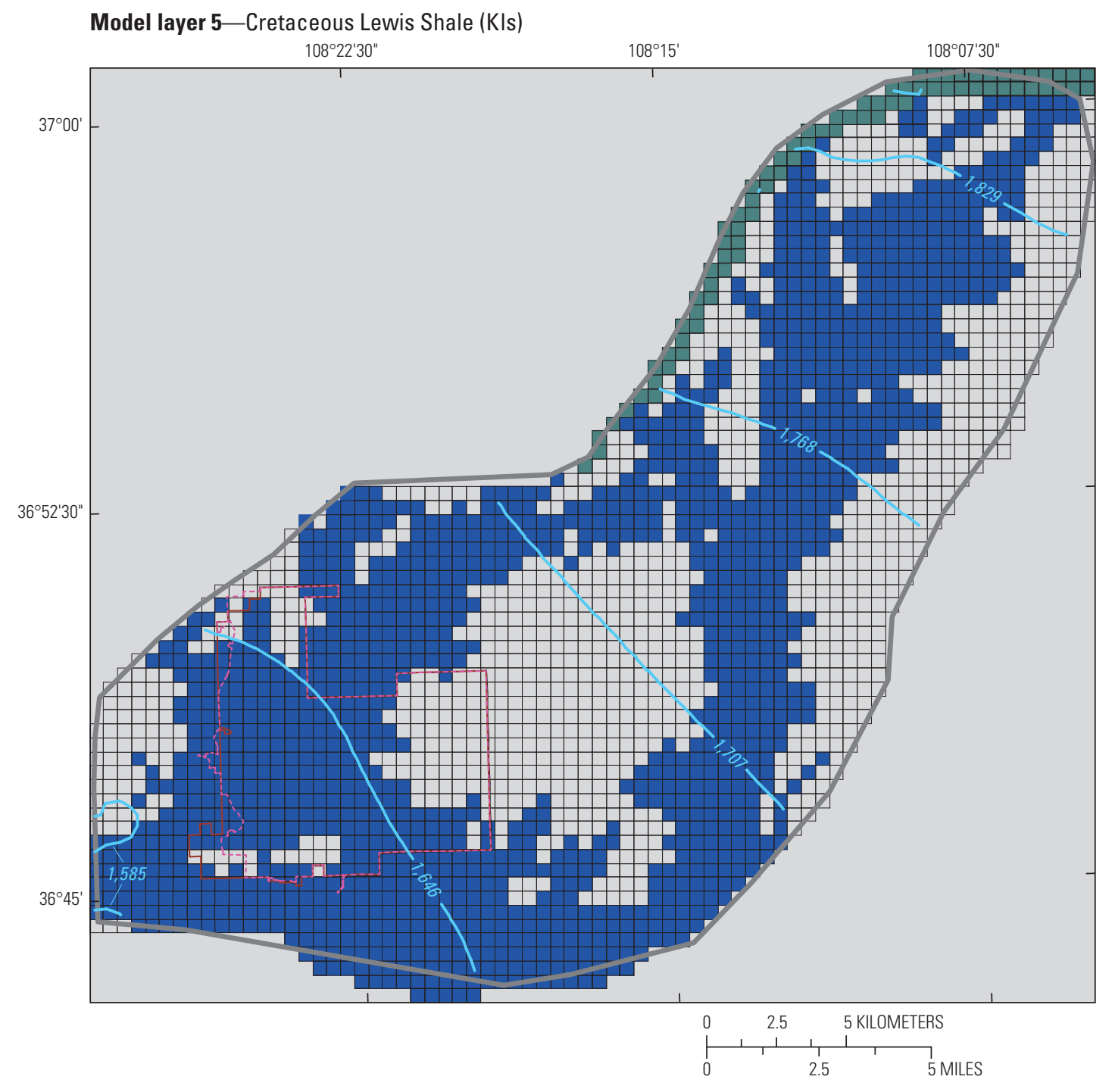

EXPLANATION

Numerical model grid cell for model layer 5

Horizontal hydraulic conductivity $(\mathrm{HC})$, in meters per day $(\mathrm{m} / \mathrm{d})$, by zone

$8.321 \times 10^{-7} \mathrm{~m} / \mathrm{d}$ (HC Zone 5$)$

$4.267 \times 10^{-3} \mathrm{~m} / \mathrm{d}$ (HC Zone 10$)$

Calibrated steady-state potentiometric contour-Shows elevation at which water level would have stood in tightly cased wells. Contour interval 61 meters. Datum is North American Vertical Datum of 1988

Study area boundary

- San Juan coal mine permit area boundary

San Juan coal mine lease area boundary

Figure 23. Layer 5 (Cretaceous Lewis Shale), calibrated hydraulic conductivity distribution, and calibrated potentiometric contours. 
Model layer 6-Cretaceous Cliff House Sandstone (Kch)

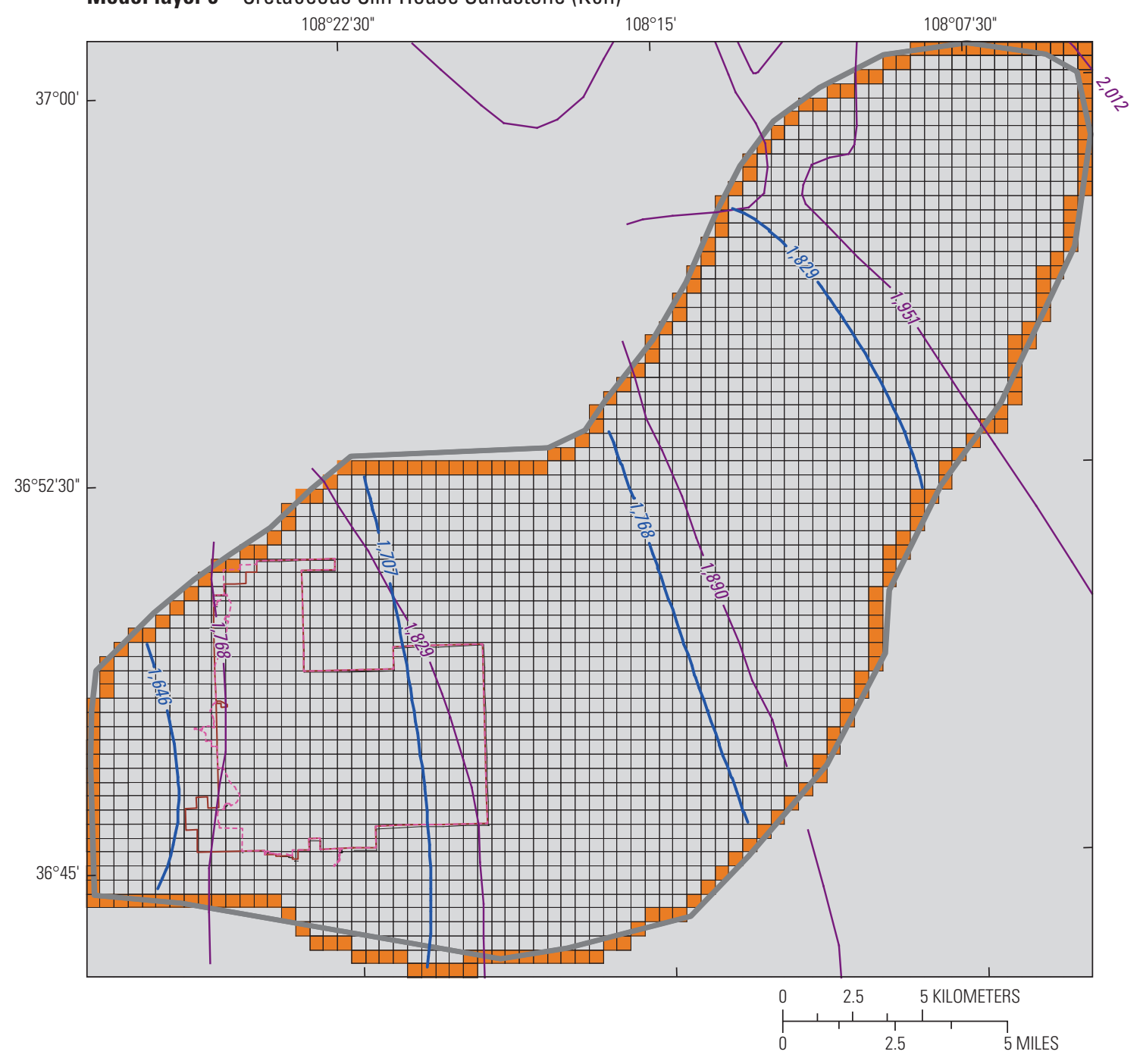

EXPLANATION

Numerical model grid cell for model layer 6

General head boundary

Horizontal hydraulic conductivity (HC), in meters per day (m/d), by zone

$3.048 \times 10^{-2} \mathrm{~m} / \mathrm{d}$ (HC Zone 6)

-1,646- Calibrated steady-state potentiometric contour-Shows elevation at which water level would have stood in tightly cased wells. Contour interval 61 meters. Datum is North American Vertical Datum of 1988 (NAVD 88)

$-1,829$ - Numerical modeling potentiometric contour for Cretaceous Cliff House Sandstone and overlying formations (Kernodle, 1996) - Shows elevation at which water level would have stood in tightly cased wells, 1996. Contour interval 61 meters. Datum is NAVD 88 Study area boundary

....... San Juan coal mine permit area boundary

San Juan coal mine lease area boundary

Figure 24. Layer 6 (Cretaceous Cliff House Sandstone [Kch]), calibrated general head boundary cells, hydraulic conductivity distribution, and potentiometric contours with Kernodle's (1996) Kch model results. 


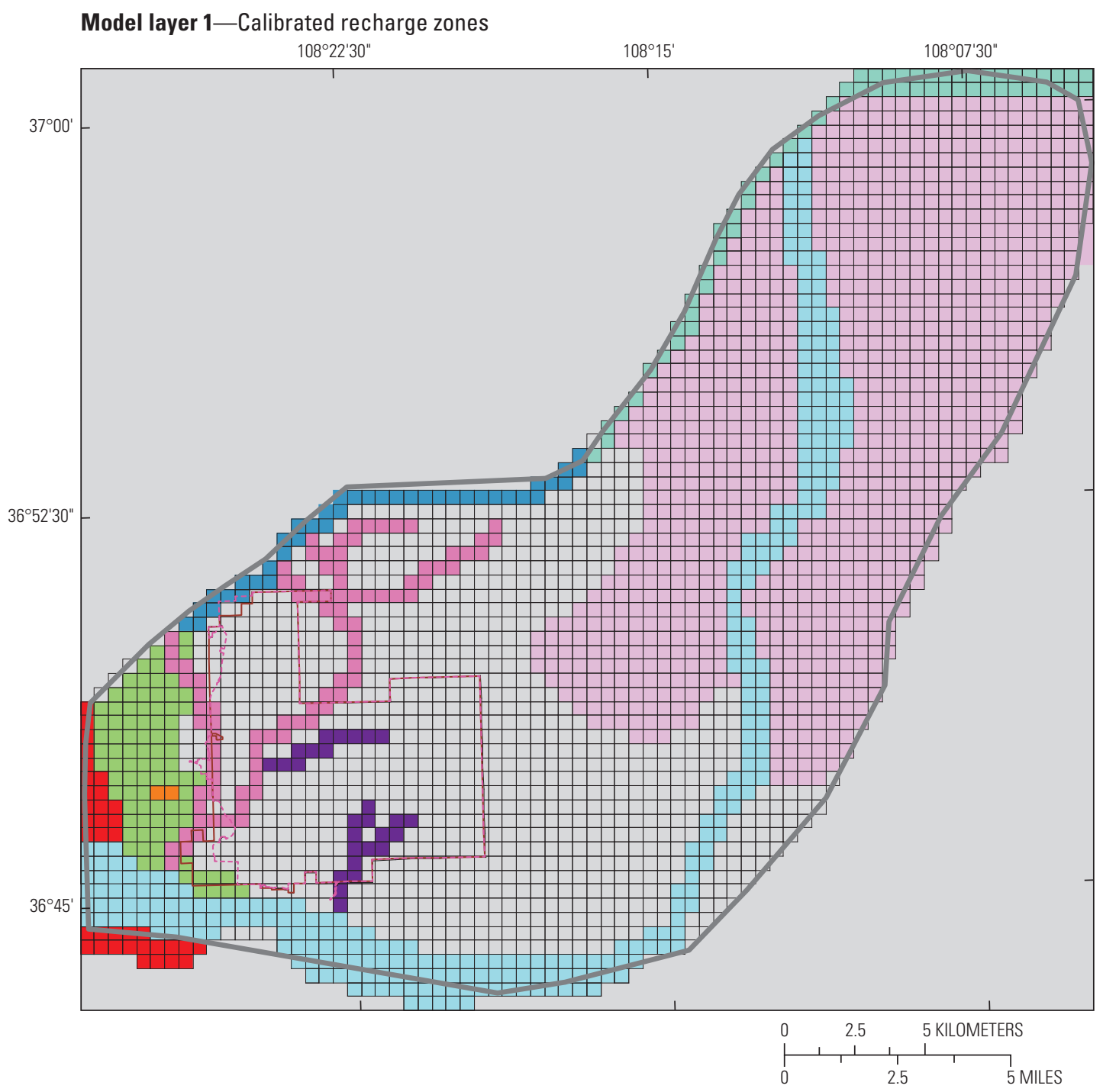

EXPLANATION

Groundwater recharge $(R)$, in meters per day $(\mathrm{m} / \mathrm{d})$, by zone for model layer 1

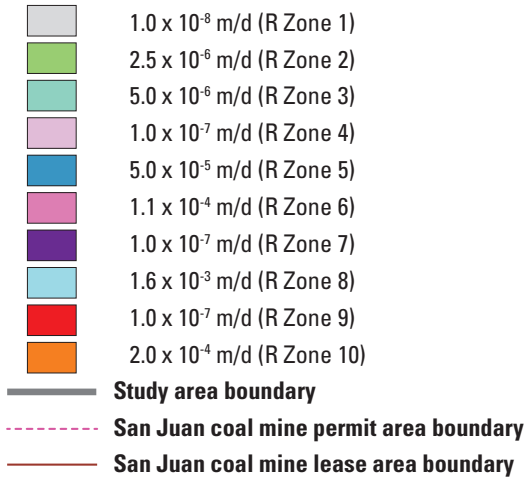

Figure 25. Calibrated groundwater recharge zones and values. 


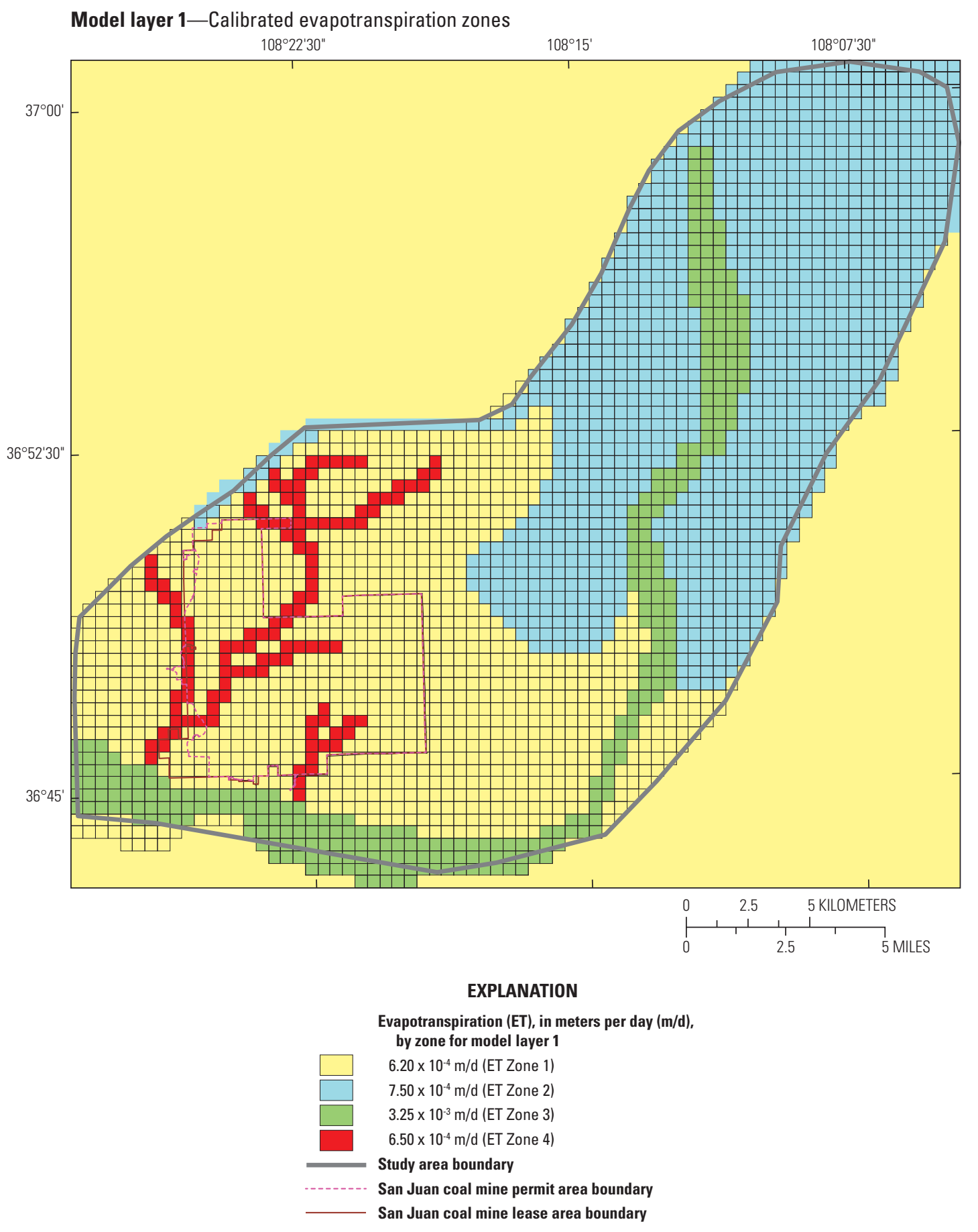

Figure 26. Calibrated evapotranspiration zones and values. 


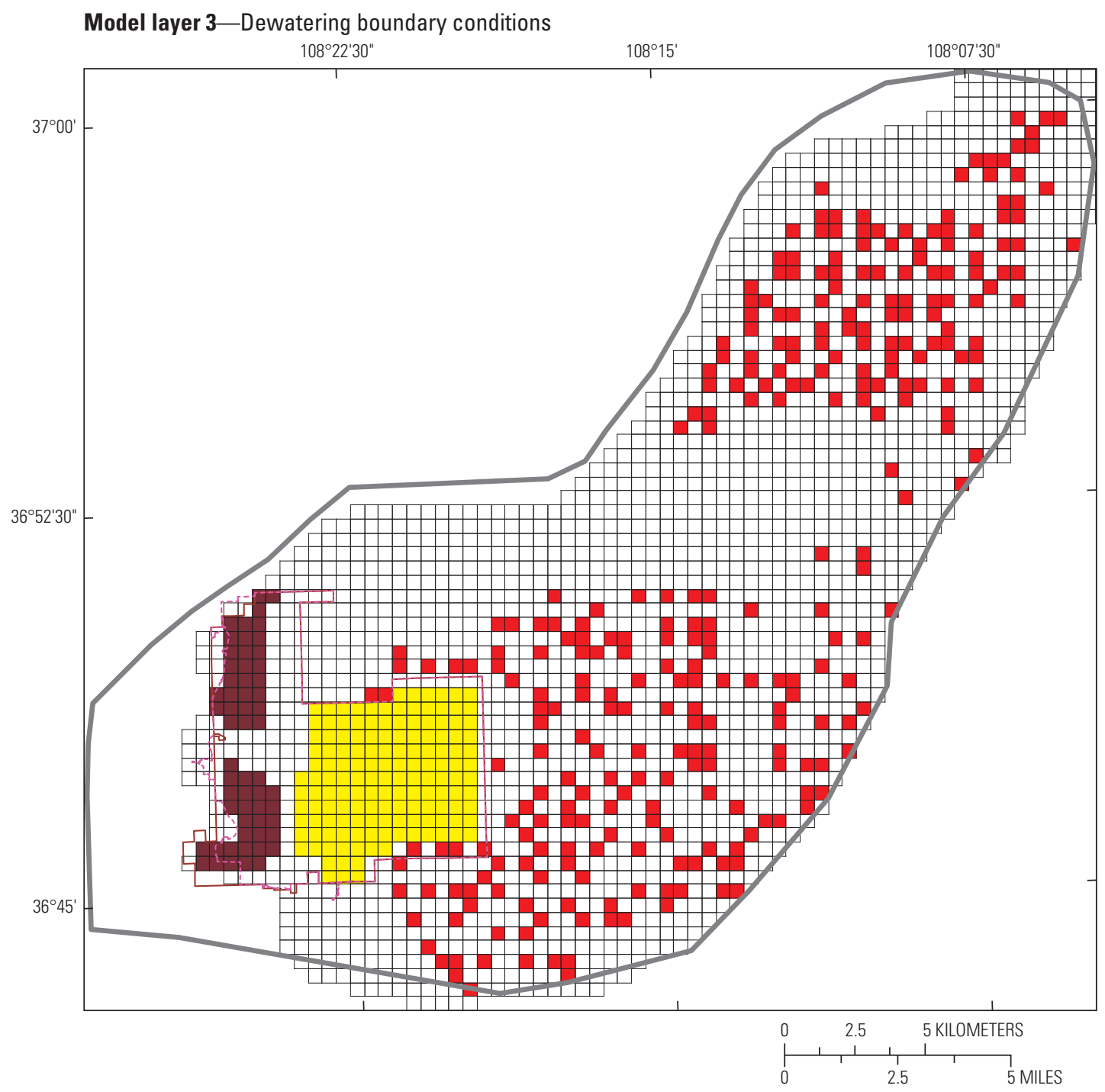

EXPLANATION

Dewatering boundary conditions for model layer 3

Oil or gas well (second transient model)

Drain (surface mine)

Drain (underground mine)

Study area boundary

San Juan coal mine permit area boundary

San Juan coal mine lease area boundary

Figure 27. Layer 3 transient drain (first and second transient models) and extraction-well boundary conditions (second transient model) related to dewatering for mining and oil and gas production. 


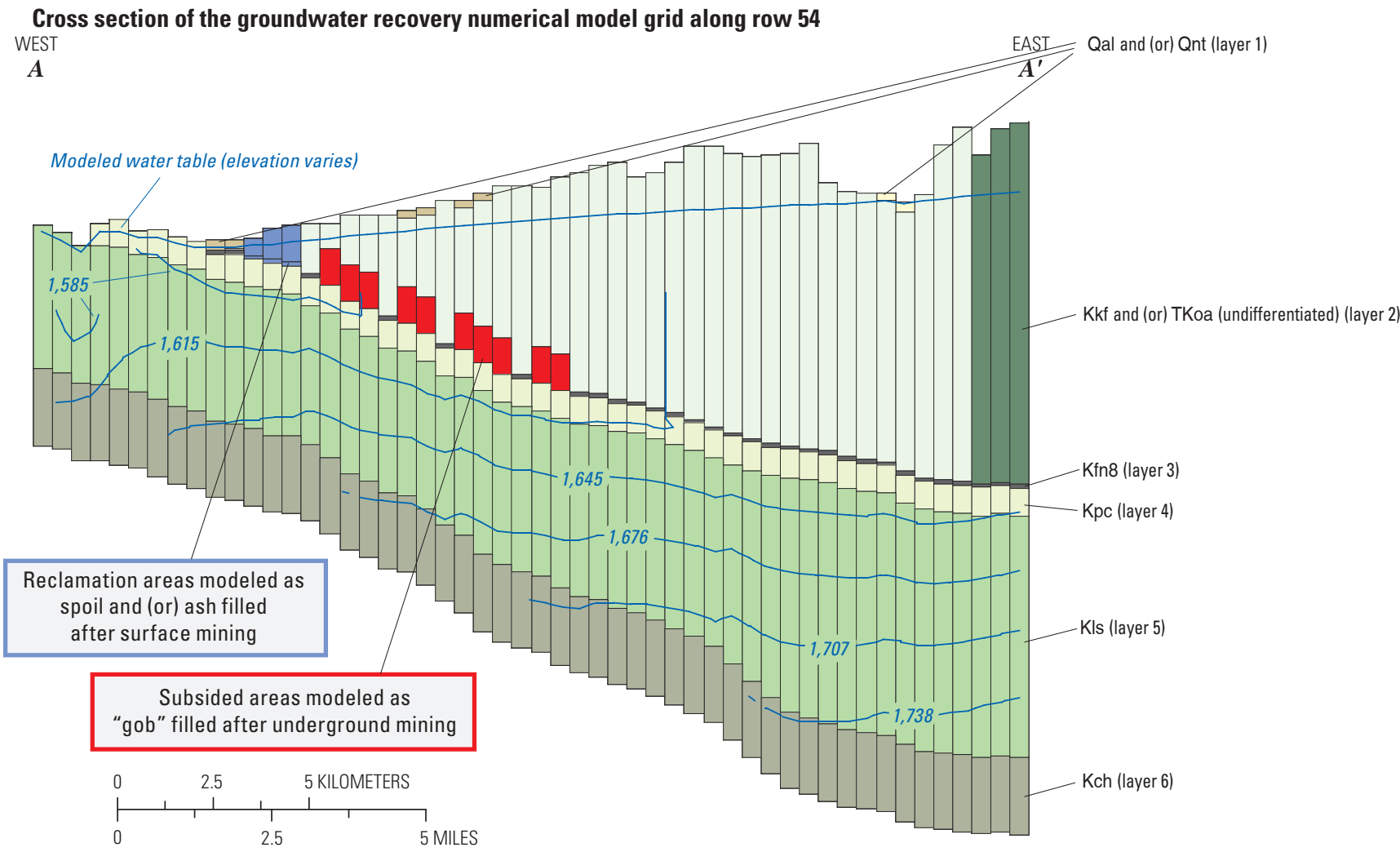

VERTICAL EXAGGERATION 20 TIMES

Surface geology map does not display changes because of mining; grid cells represent generalized locations of surficial geology features at 500 meters by 500 meters scale

\section{EXPLANATION}

Surface geology

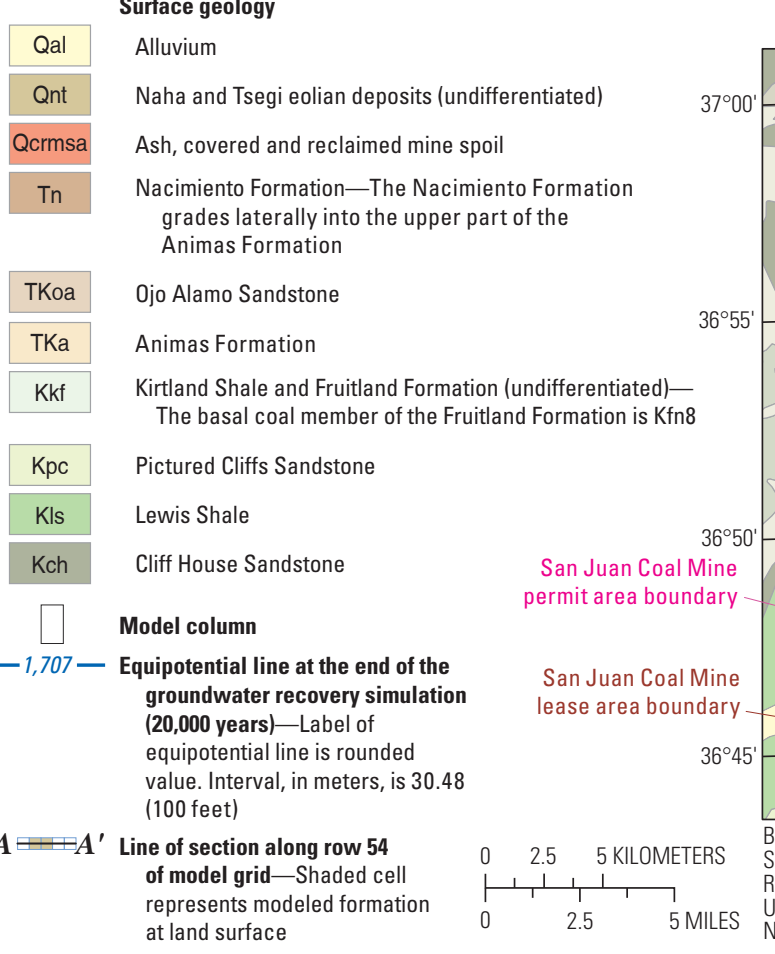

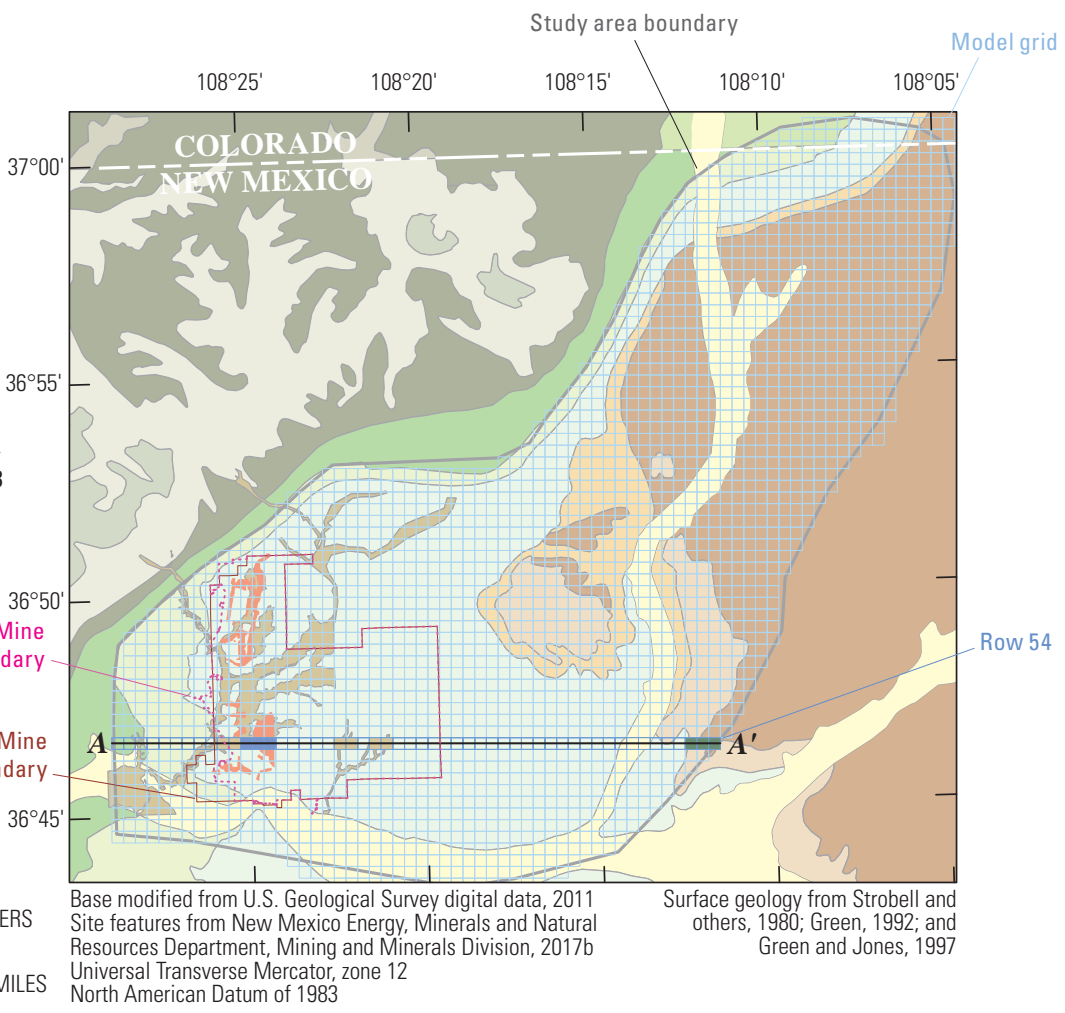

Figure 28. Cross section of the groundwater recovery numerical model grid along row 54 showing cells representing reclamation areas (purple), the underground-mine subsidence zone (red), and equipotential lines at the end of the groundwater recovery simulation $(20,000$ years $)$. 
The purposes of numerical modeling were to (1) assess time to recovery of the premining steady state at CCB storage areas, and to (2) identify groundwater-flow paths from CCB storage areas to downgradient alluvial groundwater systems. To achieve these purposes, the model, in steady-state form, was first used to calibrate hydraulic parameters and boundary conditions. Potentiometric results were then used to initiate the simulation of drawdown because of mining, and oil and gas extraction and drawdown results were used to initiate simulation of groundwater recovery.

One steady-state and three transient models were constructed. The steady-state model was used to simulate predevelopment conditions, to calibrate hydraulic parameters and boundary conditions, and to generate the predevelopment steady-state head distribution to initialize the first transient drawdown model. (Predevelopment conditions were assumed to represent the period before mining and oil and gas pumping but after lands adjacent to alluvial systems had been put into use by irrigated agricultural practices.) The first and second transient-drawdown models were used to simulate mine dewatering and oil and gas well groundwater extraction by using 1-year stress periods for each of these transient drawdown models, and are referred to hereafter as the "first transient-drawdown" and "second transient-drawdown" models. At the time of model construction, available versions of MODFLOW-NWT did not allow grid cell elevations and hydraulic parameters to be adjusted in the middle of a model run; instead, the run had to be halted, the grid adjusted, and then the run resumed. For this reason, transient dewatering was separated into two models to allow subsurface subsidence effects and hydraulic property changes resulting from surface mining and early underground mining in the first transient-drawdown model to be incorporated into the second underground mine dewatering period.

The first transient-drawdown model contains one 1-year steady-state stress period and forty-three 1-year transient stress periods representing the years 1973 through 2015, for a total of forty-four 1-year stress periods. The first steadystate stress period was assigned to bring predevelopment oil and gas dewatering, at half the rate of successive stress periods, to the steady state. (Although oil and gas dewatering was known to have occurred in the vicinity of the SJM prior to 1973, pumped water volumes could not be identified or estimated with available data.) Grid alterations of parts of the Shumway and Hutch Arroyos (at the SA [upper], SA [undermined], SABR and HA [undermined] on fig. 1B) with the contemporaneous emplacement of the Shumway and Westwater Diversion Channels were also, by necessity, included in the forcing to the steady state. Stress periods 2-29 represent oil and gas dewatering and surface-mine dewatering from 1973 through 2000. Stress period 30 was used to represent a hiatus from mine dewatering that occurred between the cessation of surface mining and the initiation of underground mining and is represented as year 2001. Stress periods 31-44 simulate underground mine dewatering from
2002 through 2015, including the hiatus from underground mining during 2012 (represented by stress period 41) when the SJM was not operated because of an underground fire (U.S. Securities and Exchange Commission, 2011).

The second transient-drawdown model simulates underground-mine and oil and gas well dewatering for a period of 18 additional years from 2016 through 2033 (stress periods 1 through 18 representing the 45th year through the 62nd year of the total dewatering period modeled). This transient model incorporates grid-cell elevation increases to Layer 3 and hydraulic property changes to Layers 2 and 3 resulting from the first 43 years of surface and underground mining (see the descriptions for Layers 2 and 3 in the section entitled “Model Layer Construction Methods”). Information for the SJM underground-mine-dewatering schedule was taken from the 2009 San Juan Mine Permit (MMD, 2017b); the estimated end-of-mining year of 2033 was provided by Westmoreland Coal Company (Eric Herth, Westmoreland Coal Company, oral commun., 2016) and may be subject to revision.

The third transient model, referred to as the "groundwater-recovery model," was used to simulate groundwater recovery from mining and oil and gas well dewatering and incorporated all hydraulic parameter and grid cell geometry changes from underground mining simulated with the first and second transient-drawdown models. Regional dewatering by oil and gas wells was assumed to cease with the cessation of mining after 2033; therefore, oil and gas pumping is not considered in the groundwaterrecovery model. (The assumption of simultaneous cessation of mine dewatering and oil and gas pumping in the vicinity of SJM is likely invalid; however, the future timing of cessation of regional oil and gas pumping is not knowable. For this simulation, only groundwater recovery without regional oil and gas pumping stresses was considered.)

Groundwater recovery was simulated over a period of 20,000 years, using 500 40-year (14,610 days) stress periods for two cases that varied only by hydraulic conductivity and porosity values for the mine spoil used to reclaim former surface-mine pits (fig. 1A). Related adjustments were applied only to the groundwater-recovery model under the assumption that rewetting and subsequent parameter-value changes applicable to swelling clays would not manifest during earlier dewatering mining phases.

Potentiometric and cell-by-cell flow results from each stress period of the groundwater-recovery model were used in MODPATH5 (Pollock, 1994) to identify advective flow paths from CCB storage sites under two scenarios or cases to potential hydraulic receptors, including the Westwater (lower) and Shumway (lower) Arroyos and the San Juan River alluvium, with the objective of estimating particle traveltimes to those potential receptors. MODPATH5 uses a semianalytical particle-tracking scheme that describes a particle's flow path within each finite-difference grid cell (Pollock, 1994). 


\section{Model Layer Construction Methods}

To construct the model grid and layers, the USGS (2017a) regional 10-m digital elevation model (DEM); regional-scale surface geology maps, 7.5-minute quadrangle maps, and surface geology maps by Green (1992), Green and Jones (1997), and Strobell and others (1980); the Kls isopach map by Dubiel (2013); reported formation-elevation contour maps by Kernodle (1996); and satellite imagery were imported into GIS projects for analysis in either digital or graphical form. The top surface-elevation matrix was constructed by regridding the $10-\mathrm{m}$ DEM to $500 \times 500 \mathrm{~m}(1,640 \times 1,640 \mathrm{ft})$ grid cells to obtain average surface elevations for each model grid cell. Bottom grid-cell elevations for alluvial cells were initially derived by subtracting assumed thicknesses from average surface elevations. Surface and basal elevations of Layer 1 grid cells, representing ephemeral stream channel alluvium, were later adjusted downward to represent the cells as groundwater sinks with reasonable minimum basal elevations and thicknesses rather than the average elevations derived from the DEM. Surface elevations were adjusted commensurately to retain reasonable representation of Layer 1 alluvium thicknesses. Layer 1 top surface elevations in cells that did not contain alluvium were assumed to represent the upper surfaces of the Kkf/TKoa, the Kfn8, the Kpc, or the Kls in Layers 2, 3, 4, or 5, respectively, depending on the location of grid cells plotted on the digital surface-geology maps of Green (1992) and Green and Jones (1997). Except for Stevens and Hutch Arroyos, which are located on or near the SJM lease area, small ephemeral watersheds in the regional study area but distant from CCB repositories (fig. 1B) were not represented in the numerical model.

Layer thicknesses and boundaries were registered to the Kpc top elevation contour map of Kernodle (1996); the contours of the Kpc top were digitized, gridded, and corrected using site specific data (Beach and Jentgen, 1978; GO-TECH, 2014, 2016; MMD, 2017b). Assumed or known formation thicknesses were registered to the Kpc top elevation grid to derive matrices of bottom-surface elevations for Layers 2-6. An apparent local subsurface hinge line (synclinal trough) originating in contours of the Kpc top surface (Kernodle, 1996) was retained and propagated to other layers (fig. 2A).

Cell thicknesses of Layers 4 and 5 at the Hogback model boundary, where dip angles are largest, were increased to ensure that cells in each layer were in sufficiently satisfactory horizontal hydraulic communication to provide numerical stability to the model; Layer 4 storage values were adjusted to accommodate, as much as possible, the effects of the adjustments.

Kernodle and Philip (1988) and Kernodle (1996) rotated their San Juan Basin finite-difference model grid to allow the application of horizontal anisotropy to saturated hydraulic conductivity fields of layers formed by marine deposition. However, Kernodle later reported that his numerical modeling results were insensitive to horizontal anisotropy and used horizontally isotropic saturated hydraulic conductivity fields for all layers (J.M. Kernodle, USGS, oral commun., 2014). The model grid prepared for this project was not rotated. Locations of model layers in relation to study area surficial geology features are shown on figure 18.

Model layers were initially constructed using Kernodle's (1996) hydraulic parameter values, if available. Otherwise, values gleaned from the literature review (table 3) were used. Precalibration hydraulic parameter and stress package (evapotranspiration and recharge) values are presented in the "Model Layer Construction Methods" subsections for each layer and for hydrologic boundaries, as applicable. Calibrated parameter values and boundary condition values are discussed in the section "Model Calibration and Sensitivity" and are presented in tables $6 A$ and $6 B$, respectively. Hydraulic conductivities, storage parameters, recharge, and evapotranspiration were zoned as HC, S, R, and ET, respectively.

\section{Layer 1: Quaternary Alluvium and Fluvially Reworked Quaternary Naha and Tsegi Eolian Deposits}

Layer 1 represents unconfined, undifferentiated Qal, which includes San Juan River and La Plata River alluvium, as well as Qnt eolian deposits with fluvially reworked Qnt (herein referred to as "Qal/Qnt") of ephemeral stream channels (fig. 19). San Juan River Qal was assigned a thickness between 20 and $30 \mathrm{~m}$ (65 and $100 \mathrm{ft}$ ). La Plata River Qal was assigned an initial thickness between 6 and $14 \mathrm{~m}$ (20 and $45 \mathrm{ft}$ ), generally following Stone and others (1983). Initial Layer 1 horizontally isotropic hydraulic conductivity values for Qal of the perennially flowing La Plata and San Juan Rivers (HC Zones 1 and 8, respectively) were assigned as $100 \mathrm{~m} / \mathrm{d}(328 \mathrm{ft} / \mathrm{d})$, and vertical hydraulic conductivity values were held at $10 \mathrm{~m} / \mathrm{d}(33 \mathrm{ft} / \mathrm{d})$, a factor of 0.1 of the horizontal value (Freeze and Cherry, 1979). Porosity was estimated at 30 percent, and specific yield (S Zone 1) was estimated at 15 percent (Johnson, 1967) for the entire layer.

Grid cells representing undifferentiated Qal/Qnt of ephemeral stream channels were generally assigned thicknesses ranging between 6 and $10 \mathrm{~m}(20$ and $33 \mathrm{ft})$ following diagrammatic sections prepared by Metric Corporation (1982). The initial horizontal hydraulic conductivity value for Qal/Qnt of ephemeral stream channels was assigned as $4.406 \mathrm{~m} / \mathrm{d}(14.5 \mathrm{ft} / \mathrm{d})$, and the vertical value was held at a factor of 0.1 of the horizontal value (one order of magnitude greater than the literature value cited in table 3; Metric Corporation, 2003, 2007).

Following surficial geologic mapping (Strobell and others, 1980; Green and Jones, 1997; MMD, 2017b), grid cells in successively underlying layers, representing the Kkf, the $\mathrm{Kfn} 8$, the Kpc, and the Kls, were variously located adjacent to or beneath Layer 1 cells representing San Juan River Qal to simulate groundwater exchange between Qal or Qal/Qnt and adjacent water-bearing units. 
Table 6A. Parameters and calibrated values used in the San Juan Mine groundwater model.

[Ksat, saturated hydraulic conductivity; m/d, meter per day; zone, MODFLOW-NWT defined zone; Qal, Quaternary alluvium; Qnt, Naha and Tsegi alluvium deposits; Kkf, Cretaceous Kirtland and Fruitland Formations, undifferentiated; TKoa, Tertiary-Cretaceous Ojo Alamo Sandstone, undifferentiated with Kkf; Kfn8, Cretaceous Fruitland Formation containing the Number 8 coal seam; CCB, coal combustion byproduct; Kpc, Cretaceous Pictured Cliffs Sandstone; Kls, Cretaceous Lewis Shale; Kch, Cretaceous Cliff House Sandstone; reach, MODFLOW-NWT streamflow routing defined boundary condition reach; $\mathrm{m}$, meter; $\mathrm{m}^{2} / \mathrm{d}$, square meter per day; S, storage; Ss, specific storage]

\begin{tabular}{|c|c|c|c|c|}
\hline \multirow[t]{2}{*}{ Layer } & \multirow[t]{2}{*}{ Hydraulic conductivity (HC) zone } & $\begin{array}{c}\text { Calibrated Ksat } \\
\text { (horizontal) }\end{array}$ & $\begin{array}{l}\text { Calibrated Ksat } \\
\text { (vertical) }\end{array}$ & \multirow[t]{2}{*}{ Notes } \\
\hline & & $\mathbf{m} / \mathbf{d}$ & $\mathrm{m} / \mathrm{d}$ & \\
\hline Layer 1 & $\begin{array}{l}\text { HC Zone 1. La Plata River alluvium } \\
\text { (Qal) }\end{array}$ & 100 & 10 & \\
\hline Layer 1 & $\begin{array}{l}\text { HC Zone 8. San Juan River alluvium } \\
\text { (Qal) }\end{array}$ & 100 & 10 & \\
\hline Layer 2 & $\begin{array}{l}\text { HC Zone 2. Kkf (unifferentiated) } \\
\text { and HC Zone 7. TKoa overlying } \\
\text { Kkf (undifferentiated) }\end{array}$ & $3.048 \times 10^{-3}$ & $3.048 \times 10^{-4}$ & \\
\hline Layer 3 & $\begin{array}{l}\text { HC Zone 3. Kfn8 adjacent to } \\
\text { Hogback HC Zone 13. Kfn8 } \\
\text { elsewhere }\end{array}$ & $6.096 \times 10^{-2}$ & $3.586 \times 10^{-3}$ & $\begin{array}{l}\text { Vertical value held at } 1 / 17 \text { of horizontal value } \\
\text { for calibration (Chen and others, 2012) }\end{array}$ \\
\hline $\begin{array}{l}\text { Layers } 2 \\
\text { and } 3\end{array}$ & $\begin{array}{l}\text { HC Zone 14. Reclaimed surface } \\
\text { mine pits composed of mine spoil } \\
\text { fill with and without CCB ash }{ }^{1}\end{array}$ & $8.64 \times 10^{-7}$ & $8.64 \times 10^{-7}$ & $\begin{array}{l}\text { Case 2, groundwater recovery model and } \\
\text { particle tracking, following Luther and } \\
\text { others, 2005, one order of magnitude smaller } \\
\text { than highest estimate) }\end{array}$ \\
\hline Layer 3 & HC Zone 15. Subsided overburden ${ }^{1}$ & $3.048 \times 10^{-3}$ & $3.048 \times 10^{-3}$ & Not calibrated \\
\hline Layer 4 & HC Zone 4. Kpc & $2.134 \times 10^{-3}$ & $2.134 \times 10^{-5}$ & \\
\hline Layer 5 & HC Zone 5. Kls & $8.321 \times 10^{-7}$ & $8.321 \times 10^{-9}$ & \\
\hline $\begin{array}{l}\text { Layers } 4 \\
\quad \text { and } 5\end{array}$ & $\begin{array}{l}\text { HC Zone } 10 . \text { Kpc and Kls Hogback } \\
\text { fractured zone }\end{array}$ & $4.267 \times 10^{-3}$ & $4.267 \times 10^{-3}$ & Zone 4 horizontal value, $\times 2$, isotropic \\
\hline \multicolumn{5}{|c|}{ General head boundary (GHB) conditions } \\
\hline \multicolumn{2}{|r|}{ San Juan River outlet } & $1,541.72-1,543.60$ & $\begin{array}{l}509-2,289 \\
\text { (varies by saturated } \\
\text { thickness) }\end{array}$ & \\
\hline Layer 6 & Kch perimeter & $1,601.50^{6}-1,902.71$ & 3.048 & \\
\hline \multicolumn{5}{|c|}{ Streamflow routing (SFR) boundaries } \\
\hline & $\begin{array}{l}\text { Head range } \\
\qquad(\mathrm{m})\end{array}$ & $\begin{array}{l}\text { Calibrated hydraulic } \\
\text { conductivity of bed } \\
(\mathrm{m} / \mathrm{d})\end{array}$ & $\begin{array}{l}\text { Calibrated thickness } \\
\text { of streambed } \\
(\mathrm{m})\end{array}$ & \\
\hline \multicolumn{2}{|c|}{ Plata River } & 0.1200 & 0.1524 & \\
\hline \multicolumn{2}{|c|}{$\begin{array}{l}\text { SFR Reach } 2 \text { San } \\
\text { Juan River }\end{array}$} & & & \\
\hline \multicolumn{2}{|c|}{$\begin{array}{l}\text { SFR Reach } 3 \text { San } \\
\text { Juan River }\end{array}$} & 0.0305 & 0.3048 & \\
\hline
\end{tabular}


Table 6A. Parameters and calibrated values used in the San Juan Mine groundwater model.-Continued

[Ksat, saturated hydraulic conductivity; m/d, meter per day; zone, MODFLOW-NWT defined zone; Qal, Quaternary alluvium; Qnt, Naha and Tsegi alluvium deposits; Kkf, Cretaceous Kirtland and Fruitland Formations, undifferentiated; TKoa, Tertiary-Cretaceous Ojo Alamo Sandstone, undifferentiated with Kkf; Kfn8, Cretaceous Fruitland Formation containing the Number 8 coal seam; CCB, coal combustion byproduct; Kpc, Cretaceous Pictured Cliffs Sandstone; Kls, Cretaceous Lewis Shale; Kch, Cretaceous Cliff House Sandstone; reach, MODFLOW-NWT streamflow routing defined boundary condition reach; $\mathrm{m}$, meter; $\mathrm{m}^{2} / \mathrm{d}$, square meter per day; S, storage; Ss, specific storage]

\begin{tabular}{|c|c|c|c|c|c|}
\hline \multirow[b]{2}{*}{ Layer } & \multirow[b]{2}{*}{ Storage (S) zone } & \multicolumn{3}{|c|}{$\begin{array}{c}\text { MODFLOW storage values } \\
\text { (layers 2, } 3 \text { and } 4 \text { calibrated for specific storage and } \\
\text { specific yield; otherwise not calibrated) }\end{array}$} & \multirow{2}{*}{$\begin{array}{c}\text { MODFLOW/ } \\
\text { MODPATH } \\
\text { parameters } \\
\text { Porosity } \\
\text { (percent) }\end{array}$} \\
\hline & & $\begin{array}{l}\text { Specific storage } \\
\left(\mathrm{Ss}, \mathbf{m}^{-1}\right)^{4,5} \\
\text { storativity } \\
\text { (S, dimensionless) }\end{array}$ & $\begin{array}{l}\text { Saturated aquifer } \\
\text { thickness (b) } \\
\text { (m) }\end{array}$ & $\begin{array}{l}\text { Specific yield } \\
\text { (percent) }\end{array}$ & \\
\hline $\begin{array}{l}\text { Layer 2, Kkf } \\
\quad \text { and TKoa } \\
\text { (unidfferentiated) }\end{array}$ & S Zone 2 & $\begin{array}{c}\text { Ss: } 1.79 \times 10^{-7} \\
\text { S: } 9.0 \times 10^{-5}\end{array}$ & $0-550^{4}$ & 1 & 40 \\
\hline Layer 3, Kfn8 & S Zone 3 & $\begin{array}{l}\text { Ss: } 1.6 \times 10^{-6} \\
\text { S: } 8.0 \times 10^{-6}\end{array}$ & 5 & 3 & 6 \\
\hline Layer 6, Kch & S Zone 6 & $\begin{array}{c}\text { Ss: } 3.0 \times 10^{-6} \\
\text { S: } 5.0 \times 10^{-5}\end{array}$ & 100 & 12.5 & 15 \\
\hline Layer 4 & $\begin{array}{l}\text { S Zone 7, adjust for elongation of } \\
\text { Kpc cells in Hogback recharge } \\
\text { area }\end{array}$ & $\begin{array}{c}8.0 \times 10^{-7} \\
--\end{array}$ & variable & 4 & 9 \\
\hline Layers 2 and 3 & $\begin{array}{l}\text { Case } 1 \text {, S Zone 8, buried minespoil } \\
\text { and ash in surface-mine pits, } \\
\text { following Metric Corporation } \\
\text { (1990) }\end{array}$ & $\begin{array}{l}\text { Ss: } 1.6 \times 10^{-6} \\
\text { S: } 5.0 \times 10^{-3}\end{array}$ & $35^{4}$ & 35 & 40 \\
\hline
\end{tabular}

\footnotetext{
${ }^{1}$ Postmining hydraulic properties were not included in steady-state model calibration.

${ }^{2}$ General head boundary conductance $=$ Ksat $*$ Wb / DX where Ksat is the saturated hydraulic conductivity value, W is cell width, always 500 m, b is saturated thickness (between $0.5 \mathrm{~m}$ and $18.36 \mathrm{~m}$ for layer 1 and $100 \mathrm{~m}$ layer 6), and DX is the distance between heads (500 m). Sensitivities are reported in conjunction with tested hydraulic conductivity ranges (above).

${ }^{3}$ Shale effective porosity and specific yield estimated following Neuzil (1994) and Fetter (1994).

${ }^{4}$ Layers 1, 2, and 5 thicknesses vary; formation thicknesses of 20 m, 500 m, and 200 m, respectively, used to estimate storage (S) for selected values of Ss (specific storage) (see note 5); Layer 2 thickness assigned as $75 \mathrm{~m}$ in MODPATH.

${ }^{5} \mathrm{Ss}=\mathrm{S} / \mathrm{b}$, where initial estimates of S, if available, were taken from Freeze and Cherry (1979).

${ }^{6}$ Kch potentiometric head values interpolated from Kernodle’s (1996) results, reduced to 1,751 m at row 31, column 29, layer 6. Results were further adjusted by $15 \mathrm{~m}$ during model calibration and were variously adjusted to match Kernodle’s hydraulic head gradient.
} 
Table 6B. Recharge and discharge stresses tested, calibrated values, and flux estimates developed for the San Juan Mine groundwater model.

[m/d, meter per day; Kkf, Cretaceous Kirtland-Fruitland Formation, undifferentiated; Kpc, Cretaceous Pictured Cliffs Sandstone; zone, MODFLOW-NWT defined zone; TKoa, Tertiary-Cretaceous Ojo Alamo Sandstone, undifferentiated with Kkf; m, meter; Qal, Quaternary alluvium; Qnt, Naha and Tsegi alluvium deposits; Kls, Cretaceous Lewis Shale; SJGS, San Juan Generating Station; Kfn8, Cretaceous Fruitland Formation containing the Number 8 coal seam]

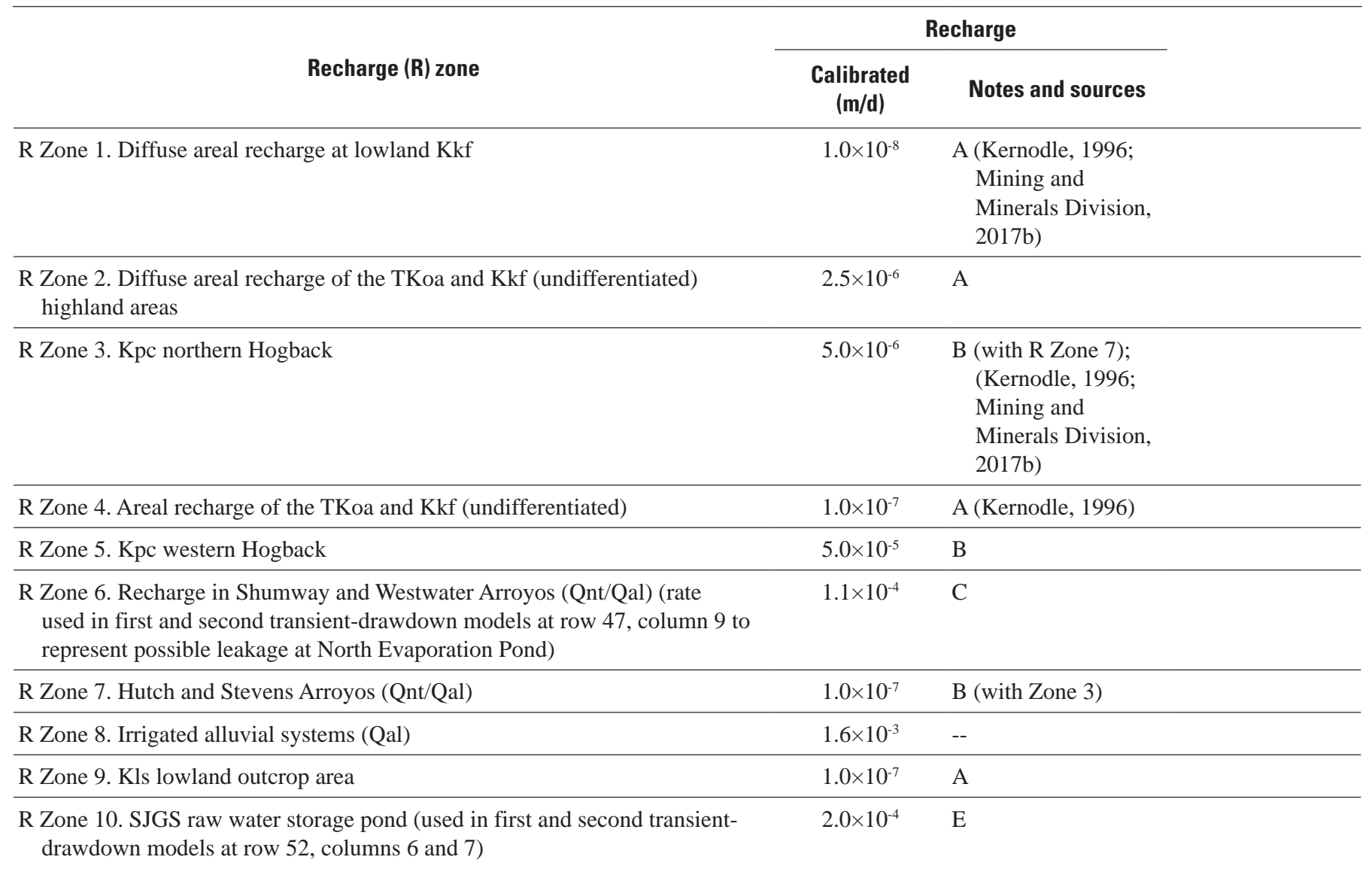

\begin{tabular}{|c|c|c|c|}
\hline \multirow{2}{*}{ Evapotranspiration (ET) zone } & \multicolumn{2}{|c|}{$\begin{array}{l}\text { Calibrated evapotranspiration } \\
\text { rates and extinction depths }\end{array}$} & \multirow{2}{*}{ Notes and sources } \\
\hline & $\begin{array}{l}\text { Rate } \\
(\mathrm{m} / \mathrm{d})\end{array}$ & $\begin{array}{l}\text { Extinction depth } \\
(\mathrm{m})\end{array}$ & \\
\hline ET Zone 1. Surficial Kkf, Kfn8, Kpc, Kls & $6.2 \times 10^{-4}$ & 8 & \multirow{2}{*}{$\begin{array}{l}\text { C; D; Thomson and } \\
\text { others (2012) }\end{array}$} \\
\hline ET Zone 2. Surficial Kkf and TKoa (undifferentiated) & $7.5 \times 10^{-4}$ & 10.1 & \\
\hline ET Zone 4. Ephemeral Channels (Qal/Qnt) & $6.5 \times 10^{-4}$ & 10.6 & $\mathrm{C} ; \mathrm{D}$ \\
\hline
\end{tabular}

A Initial range of values $\left(4.2 \times 10^{-8}-8.0 \times 10^{-6}\right.$, from Mining and Minerals Division (2017b) and Kernodle (1996), respectively, were adjusted during model calibration and sensitivity analyses.

B Initial value $\left(9.4 \times 10^{-6}\right)$ follows Kernodle’s (1996) recharge estimate of 0.13 inch per year in highland areas.

C Derived from calibration.

D Initial estimate of $1.1 \times 10^{-3} \mathrm{~m} / \mathrm{d}$ adjusted during model calibration.

E Initial recharge rate approximated as about 10 times the vertical hydraulic conductivity value for the Kpc. 
Layer 2: Cretaceous Fruitland Formation and Kirtland Shale and Tertiary-Cretaceous Ojo Alamo Sandstone (Undifferentiated), Premining and Postmining

Layer 2 represents the convertible (allowed in MODFLOW-NWT to convert between unconfined and confined conditions) Fruitland Formation (Kf), and where present, the overlying Kirtland Shale (Kks), designated herein as "Kkf" when the two units are undifferentiated. (See fig. 20, HC Zone 2, which also shows Kernodle's potentiometric results for the Kkf.) Layer 2 also includes, where present, the Tertiary-Cretaceous Ojo Alamo Sandstone, designated herein as “TKoa” (fig. 20, HC Zone 7), undifferentiated with respect to the underlying Kkf. The Kf represented in HC Zones 2 and 7 of Layer 2 excludes the basal coal seam, specifically represented as the Kf Number 8 coal seam (Kfn8, represented in Layer 3; fig. 21). The bottom-surface elevation of Layer 2 was determined as a difference of $5 \mathrm{~m}$ (16.4 ft) above Kernodle's (1996) published (adjusted) topsurface elevation of the Pictured Cliffs Sandstone (Kpc). The Kkf in Layer 2 spans vertically from the calculated Layer 2 bottom to the model surface or to the bottom of the grid cells representing the alluvium, where Qal or Qal/ Qnt is present, yielding variable grid cell thicknesses of Layer 2 that thin and eventually pinch out toward the west (figs. 2B and 28). Kernodle's (1996) horizontal and vertical saturated hydraulic conductivity parameter values for $\mathrm{Kkf}$ (HC Zone 2), $0.003048 \mathrm{~m} / \mathrm{d}(0.01 \mathrm{ft} / \mathrm{d})$ and $3.048 \times 10^{-5} \mathrm{~m} / \mathrm{d}$ $(0.0001 \mathrm{ft} / \mathrm{d})$, respectively, were used as initial values. Grid cells representing undifferentiated Kkf/TKoa (HC Zone 7) were initially assigned horizontal and vertical hydraulic conductivity values of $0.006096 \mathrm{~m} / \mathrm{d}(0.02 \mathrm{ft} / \mathrm{d})$ and $3.048 \times 10^{-5}$ $\mathrm{m} / \mathrm{d}(0.0001 \mathrm{ft} / \mathrm{d})$, respectively, honoring the formationthickness-weighting scheme of Kernodle (1996, p. 87 and fig. 41; note that the thickness of TKoa in the present study area is minimal as compared with the study area in Kernodle). These values were assessed during model calibration. Porosity, specific yield, and specific storage values applied to the S Zone $2 \mathrm{Kkf}$ and TKoa were 40 percent, 1 percent, and $1.79 \times 10^{-7} / \mathrm{m}\left(5.9 \times 10^{-7} / \mathrm{ft}\right)$, respectively.

To simulate hydrological effects of surface mining, grid cells representing all former surface-mine pits were considered to be reclaimed and filled with material dominated by mine spoil throughout the vertical extent of Layers 2 and 3 (which in unmined areas represents the coal seam mining target, described in the next section) in the second transientdrawdown model and the groundwater-recovery model. An assumed isotropic saturated hydraulic conductivity value of $7.344 \times 10^{-3} \mathrm{~m} / \mathrm{d}\left(2.41 \times 10^{-2} \mathrm{ft} / \mathrm{d}\right)$ for mine spoil, reported by Thomson and others (2012), was assigned from the top of the land surface (represented by the top of Layer 2) to the bottom of the mined-out Kfn8 coal seam in grid cells representing surface-mined areas in Layers 2 and 3 (HC Zone 14), incorporating the assumption that hydrologic properties of cover material and fill, including CCB ash where it is present, are dominated by mine-spoil properties (table 3). A value of
40 percent was assigned to mine spoil porosity, following Applied Hydrology Associates Inc. (MMD, 2017b) and Metric Corporation (1990) (table 3). An associated specific yield value of 35 percent was assigned (S Zone 8), under the assumption that specific retention is 0.05 (table 6A). Mine-spoil parameter values important for particle tracking (hydraulic conductivity and porosity) were assessed with the groundwater recovery model using two cases (scenarios).

For modeling post-underground-mining effects in the second transient-drawdown model and the groundwaterrecovery model, the bottom elevations of Layer 2 grid cells that overlie mined Kfn8 cells were raised by $42.25 \mathrm{~m}$ (138.6 ft) to represent the maximum expected ceiling of the subsidence zone (described in the section entitled "Recent Mine Spoil, Coal Combustion Byproducts (Ash), and Subsided Overburden”) and hence, the Kkf floor, following the removal of the coal seam. This maximum expected height of the subsidence zone was calculated relative to the base of Layer 3 (MMD, 2017b) and was adjusted in this study to account for the $5 \mathrm{~m}$ (16.4 ft) thick coal seam. Hydraulic properties of thinned Layer 2 grid cells located above the simulated subsidence zone ceiling were assumed to be unchanged. The potential actual decline of Layer 2 surface elevations attributable to subsidence is expected to range between 0.5 and $2.7 \mathrm{~m}$ (1.5 and $9 \mathrm{ft}$; MMD, 2017b), which was deemed sufficiently small to be ignored for numerical modeling purposes, so original surface elevations were retained in the numerical modeling grid.

\section{Layer 3: Cretaceous Fruitland Formation Number 8 (Kfn8) Coal Seam}

Layer 3 represents the convertible Kfn8 coal seam (fig. 21). For this project, the bottom surface elevation of the Kfn8 was considered to be equivalent to the top surface elevation of the Kpc (derived as described in the previous "Model Layer Construction Methods" section). A shale layer present locally between the two units in some parts of the study area was not represented in the model because the layer is not observed everywhere in the study area (Beach and Jentgen, 1978; Mercier, 2010), and the regional extent and exact locations and variable thickness of the shale could not be determined with available data. It was further assumed that any effects of the shale could be simulated adequately by adjusting vertical hydraulic conductivities of the Kрс.

The upper surface elevation of the grid cells representing the Kfn8 was calculated as a difference of $5 \mathrm{~m}(16.4 \mathrm{ft})$ above Kernodle's (1996) Kpc surface, under the assumption that the Kfn8 is of constant thickness everywhere it is present except in outcrop areas. Following MMD (2017b), horizontal and vertical hydraulic conductivities were estimated initially as isotropic with a value of $0.005 \mathrm{~m} / \mathrm{d}(0.017 \mathrm{ft} / \mathrm{d}$; tables 3 and 6A). A mapped fault (fig. 21; Mining and Minerals Division of New Mexico Energy, Minerals and Natural Resources Department, written commun., 2010) was incorporated into Layer 3 (HC Zone 12) and assessed during model calibration. 
Layer 3 representing Kfn8 was separated into HC Zones 3 and 13 (fig. 21) to investigate the possibility that Kfn8 hydraulic conductivity varies spatially with proximity to uplifted and potentially fractured areas near the Hogback. (Results of this investigation are discussed in the section "Results of Calibration and Sensitivity Analyses.”) Initial storage assignments for S Zone 3 were $8.2 \times 10^{-5} / \mathrm{m}$ $\left(2.51 \times 10^{-5} / \mathrm{ft}\right)$ for specific storage and 3 percent for specific yield (midrange; MMD, 2017b). Associated porosity values were not identified in the literature review but were assumed to be 6 percent, slightly greater than the selected value for specific yield (table 6A).

For the first transient-drawdown model that represents the initiation of mining, premining hydraulic properties and grid-cell elevations were retained in all Layer 3 grid cells. For the second transient-drawdown model (see "Spatial and Temporal Discretization” section), grid cells representing surface-mined pits in Layer 3 were treated as if they were entirely filled with mine spoil, following the treatment for Layer $2 \mathrm{Kf}$ (tables 3 and 6A). An isotropic saturated hydraulic conductivity value of $7.344 \times 10^{-3} \mathrm{~m} / \mathrm{d}\left(2.410 \times 10^{-2} \mathrm{ft} / \mathrm{d}, \mathrm{HC}\right.$ Zone 14) for mine spoil, reported by Thomson and others (2012), was assigned in grid cells representing surface-mined pits in Layer 3, incorporating the assumption that hydrologic properties of fill and cover material are dominated by minespoil properties. A value of 40 percent was assigned to represent mine spoil porosity (S Zone 8) (Metric Corporation, 1990; Applied Hydrology Associates Inc., in MMD, 2017b ). An associated specific yield value of 35 percent was assigned, under the assumption that specific retention is 0.05 (table 6A). In combination with Layer 2 hydraulic parameter assignments, this modeling treatment yielded an isotropic homogenous column from the bottom of Layer 3 to the land surface in grid cells representing the mine-spoil fill that was used, in addition to CCB ash, to reclaim surface-mined pits.

In the second transient-drawdown model, grid-cell geometries of underground mining areas that were simulated as having been mined during the first transient-drawdown modeling period were adjusted to represent underground mine waste that exhibits large variation in particle size and large porosity (gob) following subsidence (fig. 21). The gob is produced as overlying Kf breaks apart and falls, or subsides, into the void space created by removal of the coal seam. This zone of subsidence is expected to have an upper limit of $47.25 \mathrm{~m}$ to which it will propagate upward (155 ft; MMD, 2017b). The isotropic hydraulic conductivity value used to simulate the gob (HC Zone 15) was $0.003048 \mathrm{~m} / \mathrm{d}$ (0.01 ft/d, isotropic). The assigned specific yield (S Zone 9) was 30 percent, and the specific storage was $1.6 \times 10^{-6} / \mathrm{m}$ $\left(4.877 \times 10^{-7} / \mathrm{ft}\right)(\mathrm{MMD}, 2017 \mathrm{~b})$. A value of 35 percent (assuming specific retention is 0.05 ) was used to represent porosity of subsided overburden.

In the second transient-drawdown model and the groundwater-recovery model, premining hydraulic properties and cell geometries for a subset of grid cells in Layers 2 and 3 in the underground mine area were retained to represent the hydraulic behavior of unmined columns and long spans of unmined coal in accordance with the mining plan (Edward Epp, BHP Billiton, oral commun., 2012), thus ignoring some parts of overhead expansion of the gob in Layer 2 grid cells to allow the hydrologic response of unmined spans and columns to be simulated. For the groundwater-recovery model, grid-cell elevations and hydraulic property changes were similarly propagated throughout all grid cells simulated as having been mined underground during the second transient-drawdown model, thus expanding the subsidence zone, including unmined columns, and associated hydraulic properties of gob to the full extent of underground mining as represented by the SJM lease area boundary. In these transient models, Layers 2 and 3 grid cells representing unmined coal in Layer 3 were not assumed to be subject to subsidence, and the original Kfn8 and Kkf thicknesses and hydraulic characteristics were retained.

\section{Layer 4: Pictured Cliffs Sandstone}

Layer 4 is a convertible layer representing the Kpc (fig. 22). The thickness of Layer 4 was assumed to be constant at $36.57 \mathrm{~m}$ (120 ft) throughout the model domain (table 6A). The bottom elevation of the Kpc was calculated as the difference from the Kpc top-surface-elevation grid using this constant thickness value except in grid cells representing steeply dipping areas near the Hogback, where cell thicknesses were variably increased to ensure lateral hydraulic communication across the entirety of Layer 4. Kernodle's potentiometric results for the Kpc are shown in figure 22.

The horizontal and vertical saturated hydraulic conductivity parameter values (HC Zone 4) from Kernodle (1996, following Stone and others, 1983) of $2.1336 \times 10^{-3} \mathrm{~m} / \mathrm{d}$ $(0.007 \mathrm{ft} / \mathrm{d})$ and $2.1336 \times 10^{-5} \mathrm{~m} / \mathrm{d}\left(7.0 \times 10^{-5} \mathrm{ft} / \mathrm{d}\right)$, respectively, were assigned initially (table 3 ). Layer 4 porosity, specific yield, and specific storage values (S Zone 4) were initialized as 18.1 percent, 15 percent, and $1.37 \times 10^{-6} / \mathrm{m}\left(4.18 \times 10^{-7} / \mathrm{ft}\right.$, estimated because no formation values were found in the literature review), respectively.

Layer 4 grid cells representing steeply dipping Kpc areas at the Hogback were initially assigned the isotropic saturated hydraulic conductivity value of $0.021336 \mathrm{~m} / \mathrm{d}(0.07 \mathrm{ft} / \mathrm{d})$, a value one order of magnitude larger than the initial Kpc horizontal hydraulic conductivity value, to represent enhanced permeability attributable to fracture flow at the Hogback (HC Zone 10; fig. 22); the porosity and specific yield for these cells (S Zone 7) were halved from their initial values to adjust for effects of elongating the grid cells.

A local northwest-southeast subsurface hinge line (apparently representing a synclinal trough) was observed when the Kpc top-surface data from Kernodle (1996) were digitized and synthesized. The hinge line was retained in the model grid (fig. 2A).

\section{Layer 5: Lewis Shale}

Layer 5 is a convertible layer representing the Kls (fig. 23). The layer thickness was varied following the isopach map from Dubiel (2013) to estimate cell bottom elevations and 
to allow MODFLOW-NWT to calculate variations in vertical hydraulic gradients and related vertical fluxes according to variations in the Layer 5 grid cell thicknesses. The initial horizontal saturated hydraulic conductivity parameter value assigned to the Kls (HC Zone 5) was $1.52 \times 10^{-5} \mathrm{~m} / \mathrm{d}$ $\left(5 \times 10^{-5} \mathrm{ft} / \mathrm{d}\right)$, and the initial vertical saturated hydraulic conductivity value was $1.52 \times 10^{-6} \mathrm{~m} / \mathrm{d}\left(5 \times 10^{-6} \mathrm{ft} / \mathrm{d}\right)$ (table 3 ; Kernodle, 1996). Porosity, specific yield, and specific storage values assigned to Layer 5 (S Zone 5) were 40 percent, 1 percent, and $1.79 \times 10^{-7} \mathrm{~m}^{-1}\left(5.46 \times 10^{-8} \mathrm{ft}^{-1}\right)$, respectively (table 6A).

\section{Layer 6: Cliff House Sandstone}

Layer 6 (the bottom layer) represents the confined Kch (fig. 24). The vertical, and therefore hydraulic separation, between parts of the Cliff House Sandstone (Kch) located on either side of the Hogback monocline vertical displacement was assumed to be complete throughout the study area, neglecting possible connectivity with Kch recharge areas north and northwest of the study area. The Kch included in the numerical model was restricted to the part that underlies the Kls. These simplifications incorporate the assumption that excluded Kch recharge is already represented in Kernodle's (1996) steady-state Kch potentiometric surface, which was used to represent the configuration of Kch heads.

The thickness of Layer 6 (Kch) was held constant at $100 \mathrm{~m}$ (328 ft). That thickness value was subtracted from the bottom elevation of Layer 5 to define the bottom elevation of Layer 6 and thus the bottom of the model domain.

Kernodle's (1996) horizontal and vertical saturated hydraulic conductivity parameter values of $0.03048 \mathrm{~m} / \mathrm{d}(0.1 \mathrm{ft} / \mathrm{d})$ and $0.0003048 \mathrm{~m} / \mathrm{d},(0.001 \mathrm{ft} / \mathrm{d})$, respectively, were assigned to Layer 6 (HC Zone 6) for initial values (table 3). Porosity and specific storage values used to represent the Kch (S Zone 6) were 15 percent and $3.0 \times 10^{-6} \mathrm{~m}^{-1}\left(9.8 \times 10^{-6} \mathrm{ft}^{-1}\right)$, respectively (table 6A).

\section{Hydrologic Boundaries}

Boundary conditions define the locations and manner in which water enters and exits the active model domain. The specified boundaries of the model were selected to coincide as much as possible with natural hydrologic boundaries or to be sufficiently distant from the SJM to minimize boundary effects on numerical modeling results. Three types of model boundaries were used in the steady-state model: (1) no-flow (zero-flux) boundaries to define model layer extents; (2) head-dependent flux boundaries for streams, general heads, and drains; and (3) specified-flux boundaries used to represent recharge, evapotranspiration, and oil and gas well pumping. Drains and extraction wells were used to dewater grid cells in the first and second transient-drawdown models.

\section{Hydraulic Conditions along the Perimeter of the Model}

General head boundaries (GHBs) were used to represent head-dependent flux boundaries along column 1 of Layer 1 (table 6A) and the perimeter of Layer 6. In Layer 1, GHBs were used to simulate groundwater flow out of the model through San Juan River Qal (fig. 19).

Kernodle's Kch potentiometric results, in some areas, were several hundred feet above land surface, which was not supported by the single predevelopment Kch depth-towater measurement outside of but near the present study area (Irwin, 1966; summarized in table 3). Interpolated to the study area, this water level is intermediate between the findings of Kernodle (1996) and Stone and others (1983). Layer 6 GHBs were assigned about the perimeter of the simulated Kch to maintain the configuration of Kernodle's (1996) digitized hydraulic-head results (fig. 24). It should be noted that Kernodle's (1996) digitized results of the Kch potentiometric surface appear to be shifted to the south and west as assessed by emplacing the lines of equipotential to direct groundwater flow to the expected San Juan River outlet. Rather than moving the digitized results by a speculative amount, assigned head values for Layer 6 GHBs were adjusted for this presumed error by comparison of modeled hydraulic gradients to those of the shifted data. Differences were most pronounced at the northeast corner of the study area. After the lines of equipotential appeared to be reasonably represented, the GHB head values were reduced by $110 \mathrm{~m}$ (360 ft) to reduce Kernodle's adjusted potentiometric results (fig. 24) of $1,860 \mathrm{~m}(6,100 \mathrm{ft})$ to Irwin's (1966) measured Kch head of $1,750 \mathrm{~m}$ (5,740 ft) (table 3), which was projected from Row 26 Column 26 Layer 6 to Row 31 Column 29 of Layer 6. This interpreted hydraulic-head configuration was adjusted uniformly during model calibration with the aim of reducing residual error to calibration targets as described in the "Model Calibration" section. It should be noted that Irwin's measured result incorporates at least $24 \mathrm{~m}$ (80 ft) of uncertainty related to differences in Irwin's (1966) reported land surface elevation versus the mapped land surface elevation at the location of the measured well (table 3) as determined using GIS.

The GHB conductance terms are computed as the horizontal saturated hydraulic conductivity multiplied by the cell width and the saturated thickness and divided by $500 \mathrm{~m}$ $(1,640 \mathrm{ft}$, where $500 \mathrm{~m}$ is the uniform distance between hydraulic heads used in this numerical model, see table $6 \mathrm{~A}$, footnote 1). Conductance terms were adjusted as related hydraulic conductivity values were calibrated.

No-flow (zero flux) boundary conditions were used at natural hydrologic boundaries throughout the model domain to limit layer extents and otherwise to represent the general locations of assumed groundwater divides, such as the Hogback monocline and the San Juan River. Similarly, the eastern model boundary of Layers 2, 3, and 4 (figs. 20, 21 , and 22, respectively) were located along the crest of a groundwater ridge observed to be present in Kernodle’s (1996) 
Hydrologic Assessment and Numerical Simulation of Groundwater Flow, San Juan Mine, San Juan County, N. Mex.

Kkf and Kpc potentiometric results (figs. 20 and 22), east of the La Plata River. This groundwater ridge was assumed to represent a groundwater divide and thus was used as a zero-flux boundary condition. This simplification reduced the spatial size and scale of the model domain and allowed numerical modeling to be focused on conditions in the vicinity of the SJM. It should be noted that although the configurations of Kernodle's potentiometric results appear reasonable at the groundwater divide, the two most congruent equipotential lines unrealistically exceed the land surface elevation at the eastern model boundary by an average of $29 \mathrm{~m}(95 \mathrm{ft})$.

Layer 5 was truncated at the eastern zero-flux hydrologic boundary, under the assumption that horizontal flows expected to pass through it are negligible, because of the low permeability of shale; it was modeled explicitly to represent vertical hydraulic gradients that vary according to the varying thickness of the unit in the study area. The Kls outcrop near the simulated outlet of the San Juan River was retained to simulate groundwater flow between the Kls and the San Juan River Qal.

\section{Streams and Surface-Water Features}

Layer 1 contains streamflow routing (SFR) boundary conditions to represent potential (but unquantified and uncharacterized) interactions between flows in the San Juan and La Plata Rivers (fig. 19) and adjacent Qal. La Plata River flow was simulated with one stream segment composed of 77 reach cells, designated SFR Reach 1. Flow in the San Juan River was simulated with two joined stream segments composed of 59 reach cells: (1) SFR Reach 2 with 3 reach cells, and (2) SFR Reach 3 with 57 reach cells where one model grid cell (row 62 column 42), representing the confluence of Reach 1 with Reaches 2 and 3, was used in all three reaches. An initial flow of 53,700 m³ $/ \mathrm{d}\left(1.901 \times 10^{6} \mathrm{ft}^{3} / \mathrm{d}\right.$ or $22 \mathrm{ft}^{3} / \mathrm{s}$, averaged from data recorded at USGS streamgage 09366500, La Plata River at Colorado-New Mexico State line, table 2) was assigned to the most upstream cell of Reach 1 . An initial flow of $4,902,000 \mathrm{~m}^{3} / \mathrm{d}\left(1.729 \times 10^{8} \mathrm{ft}^{3} / \mathrm{d}\right.$ or $2,004 \mathrm{ft}^{3} / \mathrm{s}$, averaged from data recorded at USGS streamgage 09365000, San Juan River at Farmington, table 2) was assigned to the most upstream reach cell of SFR Reach 2 to propagate toward the grid cell representing the San Juan River confluence with La Plata River. Constant widths of $70 \mathrm{~m}(230 \mathrm{ft})$ and $10 \mathrm{~m}(32 \mathrm{ft})$ were assumed for the San Juan and La Plata Rivers, respectively. Initial stage heights of $1 \mathrm{~m}$ $(3.28 \mathrm{ft})$ and initial streambed thicknesses of $1 \mathrm{~m}$ (3.28 ft) were assumed for all SFR reach cells. Representative bed elevations, bed slopes, and relative stream lengths in each reach cell were quantified using GIS; stream stages were assigned at a constant value of $1 \mathrm{~m}$ above the bed elevation, and Manning's n was assigned at a constant value of 0.05 . An initial streambed saturated hydraulic conductivity value of $0.3048 \mathrm{~m} / \mathrm{d}(1 \mathrm{ft} / \mathrm{d})$ was assessed for all three SFR reaches during model calibration.

\section{Groundwater Recharge}

Groundwater recharge is the amount of percolating water that reaches the surface of the water table (the shallowest regionally extensive subsurface store of groundwater). In Groundwater Vistas preprocessing software (GWV), following MODFLOW conventions, recharge is assigned to designated zones in Layer 1 (fig. 25) but applied to grid cells of the layers representing the (convertible) water-bearing zone underlying the land surface at any given location in the model domain.

Groundwater recharge for the steady-state model was represented in 9 recharge zones. Recharge (R) Zones 1, 2, 6, 7 , parts of 8 , and 9 represent lowland areas and R Zones 3 , 4, 5, and parts of 8 represent highland areas (fig. 25). Diffuse areal recharge in Zone 1 was initially assigned a recharge rate of $8.0 \times 10^{-6} \mathrm{~m} / \mathrm{d}(0.115 \mathrm{in} / \mathrm{yr})$. In highland areas, R Zone 4 was initially assigned a recharge rate of $9.4 \times 10^{-6} \mathrm{~m} / \mathrm{d}(0.135 \mathrm{in} / \mathrm{yr})$ (Kernodle, 1996; table 5). Kernodle's (1996) diffuse-areal recharge zones were refined to the present modeling scale, and Kpc and Kls outcrop areas adjacent to the San Juan River (R Zones 2 and 9, respectively) were added. (In the two transient-drawdown models, R Zone 10 was assigned to represent leakage from the raw water storage pond and the grid cell at the NEP location was assigned as R Zone 6, instead of R Zone 1, to incorporate possible NEP leakage).

Focused groundwater recharge zones were incorporated to represent recharge along the Kpc of the Hogback ( $\mathrm{R}$ Zones 3 and 5), along ephemeral stream channels (R Zones 6 and 7), and from irrigation recharge that is assumed to occur in alluvium located adjacent to perennially flowing rivers (R Zone 8). Grid cells representing groundwater recharge of the Kpc along the Hogback were initially valued at $9.4 \times 10^{-6}$ m/d (0.135 in/yr), following Kernodle's (1996) estimate of groundwater recharge in highland areas. Cells representing ephemeral stream channel alluvium (R Zone 6) were initially assigned a value of $1.4 \times 10^{-4} \mathrm{~m} / \mathrm{d}$ ( $2 \mathrm{in} / \mathrm{yr}$ ) under the assumption of vertical flow for a few days each year under unit-gradient conditions, averaged on a daily basis. Grid cells representing alluvium adjacent to perennially flowing rivers (R Zone 8) were considered to be irrigated agriculture and were initially assigned a net recharge rate of $1.5 \times 10^{-3} \mathrm{~m} / \mathrm{d}$ $\left(5 \times 10^{-3} \mathrm{ft} / \mathrm{d}\right.$; based on consumptive water use for alfalfa in San Juan County on an average daily basis; Hammond Conservancy District, 2016). The determination of actual values for irrigation withdrawals, depletions, and return flows near perennially flowing streams in the study area was beyond the scope of this project.

Groundwater recharge at the Kls outcrop area that abuts the San Juan River was incorporated explicitly into the model (fig. 25, R Zone 9). Because of the very low hydraulic conductivity of this shale unit, groundwater recharge to the Kls at the Hogback was assumed to be minor, following Kernodle (1996), and Kls grid cells extending beyond the Kls at the Hogback were removed from the numerical modeling grid. 
Kernodle (1996) included Kch recharge areas in highland areas north and northwest of the Hogback monocline in his representation of the Kch. For this report, these recharge areas were considered to be outside of and disconnected from the Kch of the central basin. Under the assumption that any excluded Kch recharge is already represented in Kernodle's (1996) steady-state Kch potentiometric surface, only the Kch directly underlying the Kls was included in the numerical model, as imposed by GHBs.

For transient drawdown simulations, focused recharge as leakage from the raw water storage pond was also simulated (fig. 25, R Zone10) at a rate of $2.0 \times 10^{-4} \mathrm{~m} / \mathrm{d}(3.1 \mathrm{in} / \mathrm{yr})$. Other possible sources of transient focused recharge, such as recharge from industrial process ponds, and focused discharge, such as dewatering of Qnt/Qal at the RTW groundwater recovery well, were ignored because related descriptive data were not available for temporal and spatial characterization throughout the transient modeling period. Initial rates for focused recharge in Qal and Qnt/Qal were developed using flux estimates calculated with initial vertical hydraulic conductivity estimates, assuming a unit gradient and 3 days of annual flow, converted to daily rates.

\section{Evapotranspiration}

Evapotranspiration (fig. 26) is composed of evaporation and sublimation of groundwater at and just below land surface and transpiration of groundwater by plants. Four evapotranspiration (ET) zones were used. ET Zone 1 was used to represent lowland areas; ET Zone 2 was used to represent highland areas; ET Zone 3 was used to represent alluvial areas of irrigated agriculture; and ET Zone 4 was used to represent ephemeral stream channel areas in the vicinity of SJM. Following Thomson and others (2012), an initial evapotranspiration rate of about $1.0 \times 10^{-3} \mathrm{~m} / \mathrm{d}$ (about $14.5 \mathrm{in} / \mathrm{yr}$ ) was assigned throughout the model, with extinction depths of $8.5 \mathrm{~m}$ (28 ft) for evapotranspiration in ET Zone

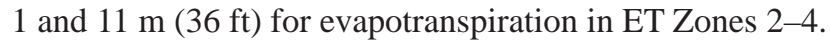
The values for evapotranspiration and extinction depths were adjusted for each ET Zone during model calibration using information summarized in table 5 .

\section{Mine and Oil and Gas Dewatering}

As described in the previous "Spatial and Temporal Discretization" section, surface-mine dewatering conducted from 1973 through 2000 is simulated temporally in stress periods 2-29 of the first-transient drawdown model. Underground-mine dewatering conducted from 2002 to 2033 (excluding 2012) is represented temporally in stress periods 31-44 (excluding stress period 41) of the first-transient drawdown model and during all 18 stress periods of the second-transient drawdown model. Oil and gas dewatering is represented during all stress periods of both transient drawdown models.

Dewatering for surface mining was represented using the MODFLOW drain package boundary conditions emplaced in the first-transient drawdown model along columns 9-14 of Layer 3 in grid cells representing areas that were surface mined between 1973 and the late 1990s (fig. 27; oil and gas wells were also placed in Layers 2, 4, and 6 but are not shown; see fig. 19 for model grid row and column numbers). Drain heads were initially assigned about $0.1 \mathrm{~m}(0.3 \mathrm{ft})$ above the base elevation of each drain cell. Several drain heads were

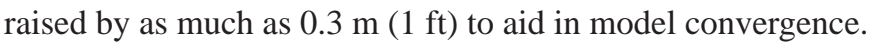
Between 2 and 8 drain cells were activated during each annual stress period. Drains were activated first in the southwestern part of the surface-mined area, then were moved to the north, and then toward the center of the site, following the reclamation schedule.

Dewatering for underground mining was similarly represented using drain boundary conditions (fig. 27). The modeled representation of the underground-mine drain dewatering schedule followed information found in the SJM permit (MMD, 2017b), and future projections incorporated all unmined parts of the SJM underground lease area. Drains were activated in the southwestern corner of the underground lease area and over time were moved north and east to represent the expansion of the underground mine workings.

Drain conductance terms were set to $3,048 \mathrm{~m}^{2} / \mathrm{d}$ $\left(32,800 \mathrm{ft}^{2} / \mathrm{d}\right)$. Conductance was calculated as hydraulic conductivity of the Kfn8 coal seam by using the steady-state calibrated value of $0.06096 \mathrm{~m} / \mathrm{d}(0.2 \mathrm{ft} / \mathrm{d})$ multiplied by cell length (500 m [1,640 ft]) and width (500 m [1,640 ft]), and divided by bed thickness ( $5 \mathrm{~m}$ [16.4 ft]). Drain conductance was assessed during model calibration.

The first and second transient-drawdown models also incorporated regional dewatering by oil and gas wells. In the first transient-drawdown model, oil and gas pumping in 72, 317, 81, and 2 grid cells was represented in Layers 2, 3, 4, and 6, respectively, where pumping in MODFLOW grid cells is represented as specified-flux boundary conditions. Oil and gas pumping locations were assigned according to reported formation-of-production names, that is, Fruitland Sandstone, Fruitland Coal, Pictured Cliffs Sandstone, or Mesa Verde Formation designations (where the Cliff House Sandstone is the uppermost unit of the Mesa Verde Formation) (GO-TECH, 2014, 2016). Pumping rates at grid-cell locations were assigned using reported average annual water extraction for the period 2013 through 2015 (converged to average daily extraction) if available. If annual average oil and gas pumping rates were not available, an average layer-based pumping rate was used for active wells. For the second transient model, specified flux boundary conditions representing oil and gas pumping inside the SJM lease boundary were removed. Figure 26 shows grid cells representing oil and gas pumping in Layer 3 in the second transient model.

\section{Modeling Approach}

The steady-state model version included only natural stresses: groundwater exchange with streamflow, groundwater recharge, and evapotranspiration. Agricultural stresses 
were incorporated using estimated groundwater recharge and evapotranspiration but were not otherwise quantified because such quantification was outside the scope of this project. The steady-state model did not include regional or local groundwater drawdown because of mining activities or oil and gas well pumping. The steady-state model was used to calibrate hydraulic parameters and boundary conditions assumed to represent predevelopment conditions, and the calibrated model was used to generate predevelopment potentiometric-head distributions for the first transientdrawdown model.

As described in the "Spatial and Temporal Discretization" section, three transient models were run successively using calibrated groundwater recharge and evapotranspiration values and calibrated hydraulic parameter values derived from steady-state modeling. The steady-state heads from the calibration model were used to initiate the first transient drawdown model. Results from this model were used to initialize the second transient drawdown model. Results from the second transient drawdown model were used to initialize the groundwater recovery scenario models. The first two transient-drawdown models were run to generate reasonable drawdown configurations induced by the simulation of oil and gas well pumping and mine dewatering (fig. 27) while successively incorporating grid and parameter value changes.

The third transient model (groundwater-recovery model) was constructed to identify groundwater recovery that was assumed to restore the predevelopment steady-state conditions over a 20,000-year modeling period and consisted of 500 40-year stress periods of one time step each. Oil and gas well pumping and mine dewatering were halted simultaneously at the start of this simulation. Applied stresses included only groundwater exchange with streamflow, groundwater recharge, and evapotranspiration and retained parameter values and stresses from the original calibrated steady-state model.

Hydraulic-head configurations and cell-by-cell flow results from the 20,000-year groundwater-recovery model were used in MODPATH 5.0 to identify advective flow paths and particle traveltimes to hydrologic receptors. Two scenarios (cases) of groundwater recovery and associated advective flow paths were simulated to assess variations in particle mobilization and transport attributable to the hydrologic properties of mine spoil that is buried with CCB ash; as previously described, SJM spoil contains a large fraction of swelling clay. Case 1 used the highest reported values for hydraulic conductivity of SJM mine spoil $\left(7.344 \times 10^{-3} \mathrm{~m} / \mathrm{d}\right.$; Thomson and others, 2012) and porosity (40 percent; Metric Corporation, 1990) (tables 3 and $6 A$ ) and thus was considered to represent a method for achieving a conservative estimate for particle migration. Case 2 used reduced values for those parameters in recognition that mine spoil contains a large fraction of swelling clay (Thomson and others, 2012) but with unknown hydrologic characteristics. The Case 2 assumptions incorporated estimates for greatly reduced hydraulic conductivity and porosity of mine spoil. The estimated hydraulic conductivity value $\left(8.64 \times 10^{-7} \mathrm{~m} / \mathrm{d}\right)$ was one order of magnitude less than Luther and others' (2005) reported highest value $\left(8.64 \times 10^{-6} \mathrm{~m} / \mathrm{d}\right.$; table 3$)$; the estimated effective porosity value of 5 percent follows Bear (1972), in recognition that standard method for determining porosity values is based on oven-dried samples, which likely will not yield true porosity values of swelling clays, which swell when in contact with water. All other calibrated parameters and stresses were held constant between the two cases. It is important to note that transport of particles through clay is likely dominated by diffusion (Johnson and others, 1989) rather than by advection (the transport mechanism applied in the present study). However, particle-track modeling was deemed to be appropriate for this first-pass numerical modeling effort. Alternate modeling approaches to particle-tracking were not included in the scope of work.

A total of 559 particles were digitized into areas of ash disposal in Layers 2 and 3 of the numerical model. In Layer 2, three-particle sets were stacked at the cell bottom, center, and top, whereas in Layer 3, single particles were placed in the vertical centers of cells representing the former location of the coal seam. Particles were tracked through the 20,000year groundwater-recovery period for the two cases of varied mine-spoil hydraulic parameters. Some particle activation times were reassigned to conform to rewetting of cells during groundwater recovery. For Case 1, 528 particles were activated, while 31 particles remained inactive. For Case 2, all 559 particles were activated.

\section{Model Calibration and Sensitivity}

\section{Calibration Methods}

Calibration of the steady-state numerical groundwater model was performed iteratively using automated parameter estimation methods (PEST; Doherty and Hunt, 2010) with manual one-at-a-time parameter- and boundary-condition sensitivity trials. The calibration goal was to identify hydraulic conductivity and boundary conditions that best simulate predevelopment hydraulic conditions (irrigated agriculture was considered to have taken place during the predevelopment period, when industrial dewatering was not occurring). The calibration method was minimization of the residual sum-ofsquares (RSS, the residual sum of squared differences between observed and simulated heads) objective function value (OFV) while maintaining consistency with the conceptual model and honoring reasonable literature-based parameter constraints (table 3).

The number of adjustable parameters varied during the steps of an extended calibration process. Horizontal and vertical hydraulic conductivities, including various combinations of anisotropy, were tested for as many as 11 zones. Anisotropic conditions were tested, including the linkage of horizontal hydraulic conductivity values with vertical values using reasonable multipliers such as application 
of a divisor of 10 to Layer 1 alluvium along the minor axis of flow with a divisor of 100 to vertical hydraulic conductivity and application of anisotropy as an independent parameter to the hydraulic conductivity of Layers 4, 5 and 6, following Kernodle's (1996) discussion on anisotropy in rocks that originated as marine-deposited sediments. As many as 9 recharge zones and 4 evapotranspiration zones were used independently to calibrate recharge and evapotranspiration rates and evapotranspiration extinction depths. The GHBs in Layer 6 were separated into four reaches so that adjustments to Kernodle's (1996) hydraulic gradient and head distribution could be assessed in the context of improvement to the OFV. The SFR bed thicknesses and hydraulic conductivity terms were calibrated regionally, assigning Reach 1 to represent the La Plata River and Reaches 2 and 3 to represent the San Juan River.

Fourteen observed early mine-development (1970s and 1980s) head values, including 6 alluvial heads (fig. 19, 3 of which were inferred as depths below land surface), $1 \mathrm{Kkf}$ head (fig. 20), 2 Kfn8 heads (fig. 21), and 5 Kpc heads (fig. 22, 1 of which was inferred), were used as steady-state calibration targets. (Calibration target locations are shown in figs. 19-22; see table 1 for calibration target short well names). The MODFLOW head-observation (HOB) package was used to account for improvements in the OFV. Two additional early mine-development head values, initially included in the steady-state calibration, proved to be intractable to calibration and were used instead to calibrate storage parameters in the first transient drawdown model (figs. 21 and 22, points shown in green). The calibration difficulties with these data points were attributed to emplacement of the associated wells after oil and gas dewatering had impacted the regional Kfn8 and Kpc groundwater systems. No known flux targets were identified for transient calibration. Improvements by calibration of storage parameters in transient simulations were assessed by inspection of observed head changes at wells SJ-24-4, SJ-13-2, and SJ-23-4 (figs. 20, 21, and 22, respectively) in the vicinity of the underground mine between stress periods 39 and 44 of the first-transient drawdown model and stress period 2 of the second-transient drawdown model. In the course of the limited transient calibration, drain conductances were reduced to improve the match with predicted underground-mine dewatering volumes (MMD, 2017b).

The steady-state model was initially populated with Kernodle's (1996) or Stone and others (1983) hydraulic conductivity values and with other hydraulic parameter values and boundary conditions that conformed to the range of known constraints (table 3 ) in accordance with the conceptual model (summarized in table 5). For calibration, this model version was run variously with PEST and with one-at-a-time factor-of-ten local changes in horizontal and vertical hydraulic conductivity parameter values, SFR conductance terms, streambed-thickness estimates, GHB heads in Layer 6, and initial groundwater-recharge and evapotranspiration estimates. The PEST calibration results tended to be dominated by that algorithm's imperative to minimize the two recalcitrant residuals previously described, producing hydrologically unreasonable results that were rejected and justifying the removal of the problematic data points from the steady-state calibration. Several adjustments to model structure were tested during the lengthy calibration process, including consideration of multiple hydraulic conductivity zones for Layers 2 and 3 and various configurations of anisotropy previously described. The sensitivity of heads assigned to Layer 6 GHBs was assessed on a layerwide basis, retaining Kernodle’s 1996 Kch potentiometric configuration but adjusting head values relative to other layers. The Kch GHB conductance terms were always adjusted with changes to Kch horizontal hydraulic conductivities. The sensitivity of the numerical model to changes in Layer 1 GHB heads was not tested because GHB heads are tightly controlled by the low-relief topography of the San Juan River alluvial system.

Results were assessed by comparing OFVs produced from local sensitivity runs with the best OFVs of prior runs. Parameter and boundary condition changes that produced marked minimization of the OFV generally were accepted unless tested values that improved model performance in one part of the model domain deteriorated model performance elsewhere or parameter interactions were suspected (for example, changes to HC Zone 10 were observed to interact with changes to Zone 3 recharge rates). Model versions with alternate structures produced OFVs in the range of about 100 $300 \mathrm{~m}^{2}$ (about 1,075-3,230 $\mathrm{ft}^{2}$ ); however, these model versions incorporated GHBs that were used to reduce heads at the eastern no-flow boundary in Layers 2, 3, and 4. This modeling scenario markedly improved the OFV for the two previously discussed recalcitrant residuals, which were generally insensitive to other parameter or boundary condition changes. This model structure was rejected because it did not conform to the no-flow east-side boundary condition as adopted in the conceptual model. The result of testing this alternative model is notable because it supports the observation that the earliest head measurements at the Kfn8 and Kpc wells in the vicinity of the underground mine were obtained after regional oil and gas dewatering had already impacted steady-state predevelopment conditions in the study area.

As changes in hydraulic parameters, recharge, and evapotranspiration were imposed sequentially on the model, the MODFLOW-NWT solver exhibited sensitivity to solver variables including the learning rate reduction factor (DBDTHETA), the residual change tolerance (BACKTOL), and the time-step reduction factor (BACKREDUCE) (see section "Groundwater Flow Process/Solvers/NWT - Newton Solver/Suggested input values for the NWT input file" in USGS, 2015). The sensitivity to solver variables produced convergence failures at grid cells representing thin-layered ephemeral-stream-channel alluvium, and the previously described hydrologically unreasonable results from the PEST automated calibration tool. Convergence failures were managed by performing manual trials, testing values for surficial stresses iteratively with solver variables until model 
convergence was achieved. MODFLOW-NWT convergence failures variably impacted OFVs depending on the proximity of calibration targets to locations of failed convergence in the model domain. During this phase of model calibration, the top and bottom elevations of Layer 1 grid cells representing ephemeral stream channels were lowered to improve the representation of these grid cells as sinks as well as to aid with model convergence.

\section{Results of Calibration and Sensitivity Analyses}

The calibrated steady-state model generates a residual sum of squared differences (RSS) OFV of $33.2531 \mathrm{~m}^{2}$ $\left(357.9334 \mathrm{ft}^{2}\right)$ with a square root of $5.77 \mathrm{~m}(18.91 \mathrm{ft})$. Calibration targets with postcalibration residuals are shown in figure 29 and also are shown with model parameters, boundary conditions, and layer-specific simulated steadystate equipotential results in figures 19-22, respectively, for Layers 1-4. Global sensitivities of calibrated model input variables are shown in figure 30 .

Absolute residuals in Layer 1 ranged between $0.49 \mathrm{~m}$

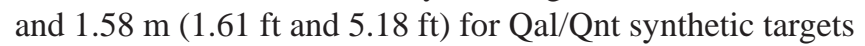
Alluvium R58 C6 and GE, respectively (figs. 19 and 29). The residual for the single Kkf early development head target SJ-24-4 was $3.28 \mathrm{~m}$ (10.76 ft, figs. 20 and 29). Residuals for Kfn8 targets G26 and G3 ranged between $3.06 \mathrm{~m}$ and $0.02 \mathrm{~m}$ (3.78 ft and $0.07 \mathrm{ft}$, fig. 21), respectively. Residuals for Kpc targets Duck Pond Arroyo and BDMKPC ranged between $1.50 \mathrm{~m}$ and $0.39 \mathrm{~m}$ (4.92 ft and $1.28 \mathrm{ft}$ ), respectively (fig. 22).

Local calibration of horizontal and vertical hydraulic conductivity values was performed for each $\mathrm{HC}$ zone using multipliers of 0.1 and 1.0 (for alluvium, 0.5 and 2). Results were assessed according to minimization of the OFV. Results did not justify using separate HC zones in Layers 2 and 3; however, HC Zones 7 (Layer 2) and 13 (Layer 3) were retained throughout testing and calibration although these zones were populated with parameter values for $\mathrm{HC}$ and $\mathrm{S}$ Zones 2 and 3, respectively. These calibration results imply that the minor presence of TKoa in the present study area (as compared to Kernodle's [1996] study area) is insufficient to affect the local Kkf groundwater system, and furthermore, Kfn8 permeability is not affected by fractures near the Hogback monocline. However, the OFV improved when the HC Zone 2 vertical conductivity value was increased from 0.01 times to 0.1 times the horizontal value (changed to $3.048 \times 10^{-4} \mathrm{~m} / \mathrm{d}[0.001 \mathrm{ft} / \mathrm{d}]$, table $6 A$ ). The OFV also improved when the HC Zone 3 horizontal hydraulic conductivity value was assigned the value of $6.096 \times 10^{-2} \mathrm{~m} / \mathrm{d}(0.2 \mathrm{ft} / \mathrm{d})$, and vertical values were assigned as one-seventeenth of the horizontal value $\left(3.586 \times 10^{-3} \mathrm{~m} / \mathrm{d}\left[1.18 \times 10^{-2} \mathrm{ft} / \mathrm{d}\right]\right)$ following Chen and others (2012).

Kernodle’s (1996, following Stone and others, 1993) initial horizontal and vertical saturated hydraulic conductivity parameter values for the Kpc (HC Zone 4) of $2.1336 \times 10^{-3} \mathrm{~m} / \mathrm{d}$ $(0.007 \mathrm{ft} / \mathrm{d})$ and $2.1336 \times 10^{-5} \mathrm{~m} / \mathrm{d}\left(7.00 \times 10^{-5} \mathrm{ft} / \mathrm{d}\right)$, respectively, were retained through the calibration process. The horizontal and vertical saturated hydraulic conductivity parameter values derived from calibration for the Kls (HC Zone 5) were $8.321 \times 10^{-7} \mathrm{~m} / \mathrm{d}\left(2.73 \times 10^{-6} \mathrm{ft} / \mathrm{d}\right)$ and $8.321 \times 10^{-9} \mathrm{~m} / \mathrm{d}$ $\left(2.73 \times 10^{-8} \mathrm{ft} / \mathrm{d}\right)$, respectively.

The HC Zone 10 in Layer 4, which was added to represent enhanced permeability at steeply dipping Kpc near the Hogback attributed to fracture flow, was retained. The calibrated isotropic hydraulic conductivity value was $0.0043 \mathrm{~m} / \mathrm{d}(0.014 \mathrm{ft} / \mathrm{d})($ table $6 A)$.

Kernodle's (1996) horizontal and vertical saturated hydraulic conductivity parameter values of $0.03048 \mathrm{~m} / \mathrm{d}$ $(0.1 \mathrm{ft} / \mathrm{d})$ and $0.0003048 \mathrm{~m} / \mathrm{d}(0.001 \mathrm{ft} / \mathrm{d})$, respectively, were retained in Layer 6 (fig. 24). Explicit zonation of Layer 6 GHB heads failed to reproduce Kernodle’s (1996) Kch potentiometric configuration, and was rejected. Initial values for Layer 6 GHB heads in the Kch, obtained from Kernodle's (1996) numerical modeling results and adjusted following Irwin (1966), were further reduced by $15 \mathrm{~m}$ (50 ft) during model calibration. Also during model calibration, the Layer 6 GHB configuration was adjusted variably in an attempt to improve the match between calibration results and Kernodle's (1996) Kch potentiometric hydraulic-head gradients so as to direct Kch groundwater flow toward the expected San Juan River alluvium outlet.

The SFR streambed thickness and conductance terms initially were assumed to be uniformly $1.0 \mathrm{~m}(3.28 \mathrm{ft})$ and $0.3048 \mathrm{~m} / \mathrm{d}(1.0 \mathrm{ft} / \mathrm{d})$, respectively. The OFV improved (was minimized) as cell thicknesses of Reach 1 SFR (representing La Plata River) and cells of Reaches 2 and 3 (representing San Juan River) were adjusted to $0.1524 \mathrm{~m}(0.5 \mathrm{ft})$ and $0.3048 \mathrm{~m}$ (1.0 ft), respectively, following iterative performance of PEST and manual sensitivity runs. The OFV also improved as the hydraulic conductivity of streambeds was reduced to $0.12 \mathrm{~m} / \mathrm{d}$ $(0.4 \mathrm{ft} / \mathrm{d})$ for Reach 1 (La Plata River) and to $0.0305 \mathrm{~m} / \mathrm{d}$ $(0.1 \mathrm{ft} / \mathrm{d})$ for Reaches 2 and 3 (San Juan River).

Initial groundwater recharge rates generally followed Kernodle (1996) but were allowed to vary according to results of Stone's (1987) recharge study performed south of the present study area and modeling results reported in the SJM permit (MMD, 2017b). Initial evapotranspiration rates generally followed Thomson and others (2012) and modeling results reported in the SJM permit (MMD, 2017b). Calibration of groundwater recharge and evapotranspiration were performed on the basis of improvements to the OFV, subject to identified constraints (table 5). Initial diffuse-areal recharge rates were tested during model calibration and adjusted to $1.0 \times 10^{-8} \mathrm{~m} / \mathrm{d}\left(1.44 \times 10^{-4} \mathrm{in} / \mathrm{yr}\right)$ on lowland areas of the $\mathrm{Kkf}$ (R Zone 1, see fig. 25 for recharge zone locations) and to $1.0 \times 10^{-7} \mathrm{~m} / \mathrm{d}\left(1.44 \times 10^{-3} \mathrm{in} / \mathrm{yr}\right)$ on highland areas of the Kkf/ TKoa (R Zone 4). Kpc (R Zone 2) and Kls (R Zone 9) outcrop areas within valley floor areas were adjusted during model calibration to $2.5 \times 10^{-6} \mathrm{~m} / \mathrm{d}\left(3.6 \times 10^{-2} \mathrm{in} / \mathrm{yr}\right)$ and $1.0 \times 10^{-7} \mathrm{~m} / \mathrm{d}$ $\left(1.44 \times 10^{-3} \mathrm{in} / \mathrm{yr}\right)$, respectively. 


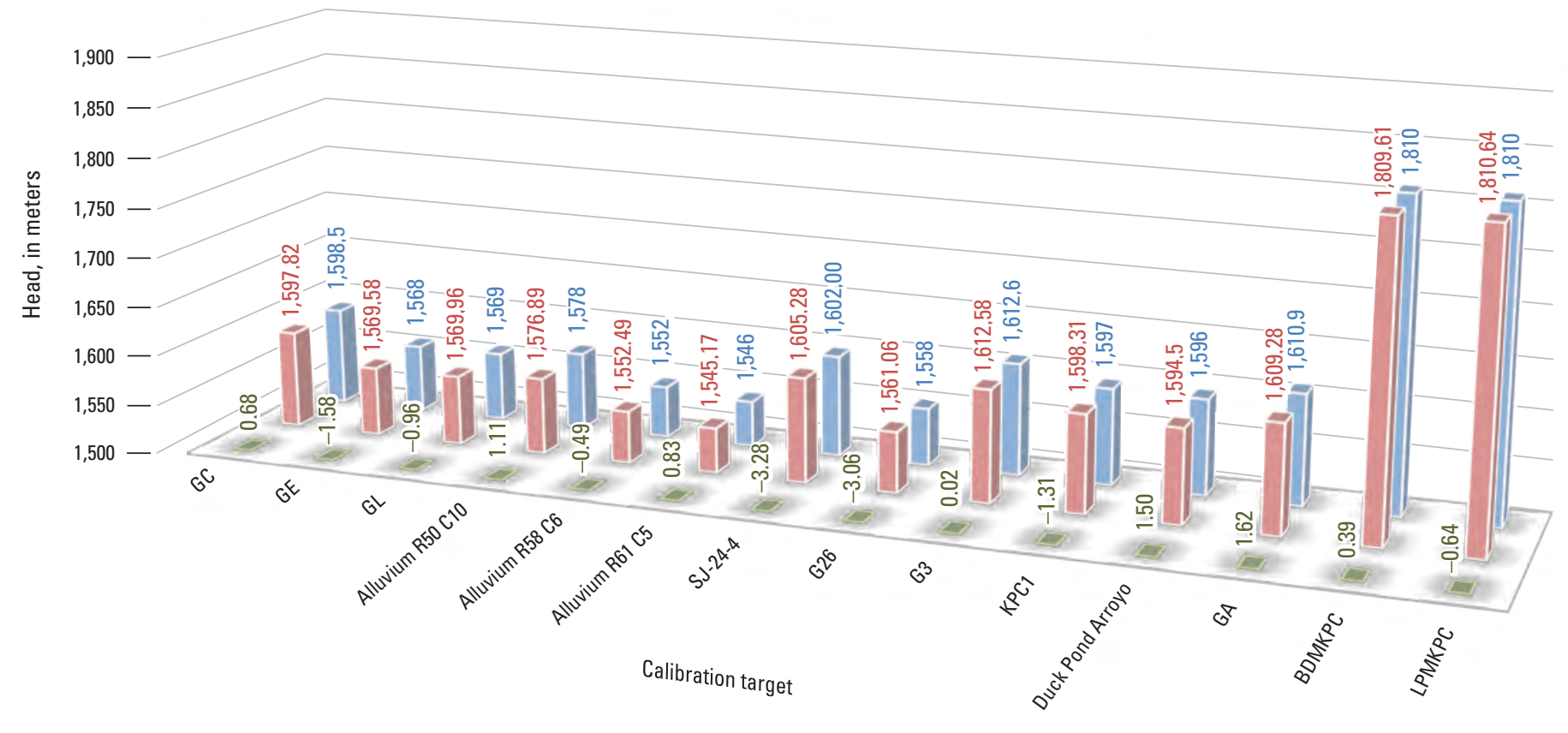

\section{EXPLANATION}

San Juan Mine steady-state calibrated numerical groundwater model head and value

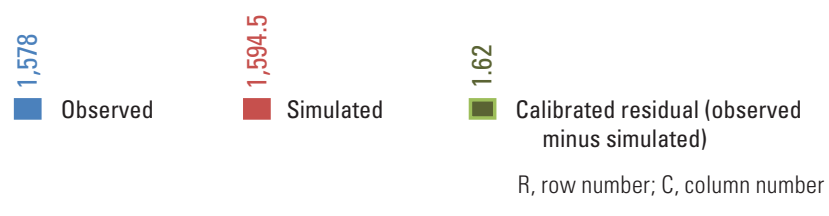

Figure 29. Residual, simulated, and observed heads at 14 steady-state calibration targets, San Juan Mine numerical groundwater model. 


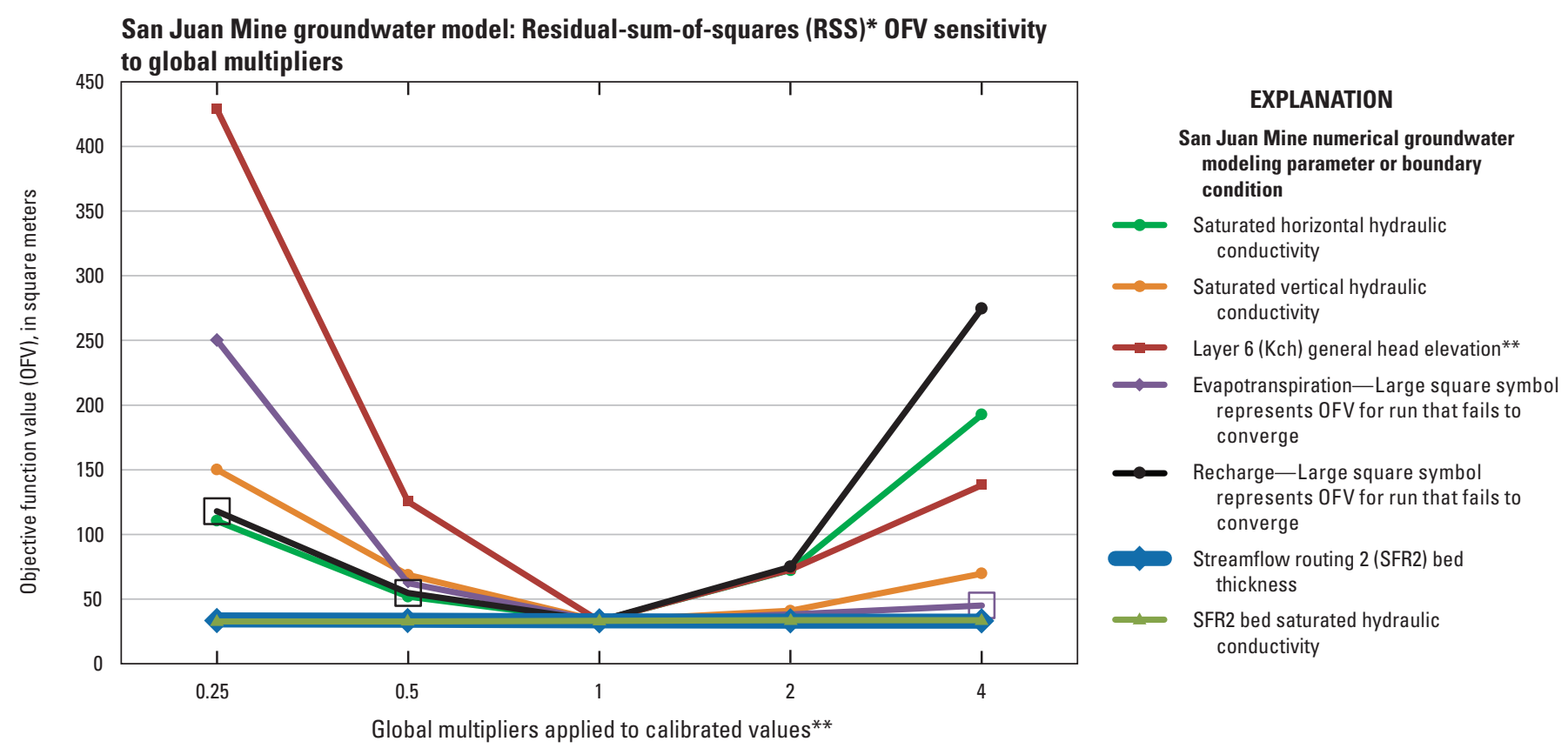

${ }^{*}$ RSS, the residual sum of squared differences between observed and simulated heads

${ }^{*}$ Cretaceous Cliff House Sandstone (Kch) head elevations in Layer 6 adjusted by superposition using negative 30, negative 15, positive 15, and positive 30 meters, respectively, at multiplicative factors of $0.25,0.5,2$, and 4

Figure 30. Global model input sensitivities tested using multiplicative factors of $0.25,0.50$, 2, and 4 . Layer 6 general head elevations tested using $-30 m,-15 m,+15 m$, and $+30 m$, respectively.

Calibrated focused-recharge rates for grid cells representing the Kpc Hogback outcrop area (R Zones 3 and 5) ranged from $5.0 \times 10^{-6} \mathrm{~m} / \mathrm{d}\left(7.2 \times 10^{-2} \mathrm{in} / \mathrm{yr}\right)$ to $5.0 \times 10^{-5} \mathrm{~m} / \mathrm{d}$ (about $0.72 \mathrm{in} / \mathrm{yr}$ ), and the calibrated recharge rate for the nearby Kkf Hogback area (R Zone 7) was $1.0 \times 10^{-7} \mathrm{~m} / \mathrm{d}$ $\left(1.44 \times 10^{-3} \mathrm{in} / \mathrm{yr}\right)$. The calibrated focused-recharge rates for grid cells representing ephemeral stream channels (R Zone 6) were $1.1 \times 10^{-4} \mathrm{~m} / \mathrm{d}(1.58 \mathrm{in} / \mathrm{yr})$ prior to applied evapotranspirative losses.

During model calibration, the evapotranspiration value for surficial $\mathrm{Kf}$ and $\mathrm{Kkf}$ (ET Zone 1 ) was reduced to $6.2 \times 10^{-4} \mathrm{~m} / \mathrm{d}(8.9 \mathrm{in} / \mathrm{yr})$, the evapotranspiration value for highland areas (ET Zone 2) was increased to $7.5 \times 10^{-4} \mathrm{~m} / \mathrm{d}$ (about $10.8 \mathrm{in} / \mathrm{yr}$ ), and the evapotranspiration value for Qal adjacent to perennially flowing rivers (ET Zone 3 ) was adjusted to $3.25 \times 10^{-3} \mathrm{~m} / \mathrm{d}$ (46.7 in/yr), in consideration of the presence of irrigated agricultural lands in these areas. An evapotranspiration value of $6.50 \times 10^{-4} \mathrm{~m} / \mathrm{d}$ (about $9.13 \mathrm{in} / \mathrm{yr}$ ) was derived for Qal adjacent to ephemeral stream channels (ET Zone 4). Extinction depths of $8.0 \mathrm{~m}$ (26 ft) for ET Zone 1, $10.1 \mathrm{~m}$ (33.1 ft) for ET Zone 2, $8.6 \mathrm{~m}$ (28.3 ft) for ET Zone 3, and $10.6 \mathrm{~m}$ (34.8 ft) for ET Zone 4 were derived from PEST runs and modified as needed to overcome model convergence failures.

As shown in figure 30, the OFV of the accepted steadystate model version either does not change or deteriorates (increases) with global multiplicative factors of one-fourth, one-half, 2, and 4 of calibrated horizontal or vertical hydraulic conductivities and of recharge and evapotranspiration fluxes. The model is insensitive to changes in calibrated SFR bed thicknesses and conductance (hydraulic conductivity), indicating that potentiometric heads in the vicinity of the SJM lease area are not impacted by regional surficial flows. The model is sensitive to adjustments of the final calibrated head values assigned to Layer 6 (Kch) general head boundary cells (using adjustments of plus or minus 30 and $15 \mathrm{~m}$ ).

During transient model calibration, the selected storage values for Layers 3 and 4 generally produced the observed range of potentiometric fluctuations observed at wells SJ-23-4 and SJ-13-2 for stress periods representing the period between 2010 and 2015; however, this effort underscored that uncertainties in oil and gas and mine dewatering schedules may also account for potentiometric fluctuations at these wells during that same period. Selected storage values and adjustments to the mine dewatering schedule generally produced a reasonable representation of a cone of depression for initiating the groundwater recovery model.

Also during transient model calibration, drain conductances for all drain cells were reduced to $3.048 \mathrm{~m}^{2} / \mathrm{d}$ to better match predicted mine dewatering estimates (table 5). Reasonable values for pond leakage rates were incorporated into the two transient drawdown models; however, actual 
values are unknown. Transient model results at Well-QNT, at KPC1, and at the Duck Pond Arroyo, reviewed from the first transient drawdown model, do not display increases in potentiometric elevations that could be attributed to leakage from the NEP or the raw water storage pond.

\section{Modeled Steady-State Hydraulic Heads and Water Balances}

Steady-state potentiometric configurations for model layers 2-6 are shown in figures 20-24. In general, all potentiometric modeling results indicate that groundwater flows from recharge areas at the Hogback and northern highland parts of the study area towards the outlet at the San Juan River in conformance with the conceptual model.

A daily water balance for the steady-state model and component layers is summarized in table 7 and, if available, includes comparisons with initial head and flux estimates from table 5. Terms for water balances by layer and zones were obtained from GWV. The full-model water balance indicates that sources of groundwater are diffuse areal recharge (55 percent, calculated as recharge divided by total water into the model multiplied by 100) and focused stream leakage from perennially flowing rivers (44 percent, calculated as total stream leakage into the model divided by total water into the model multiplied by 100), whereas losses of groundwater are mainly from evapotranspiration (54 percent, calculated as total evapotranspiration out of the model divided by total water out of the model multiplied by 100), and leakage to streams (45 percent, calculated as total stream leakage out of the groundwater system divided by total water out of the model multiplied by 100). Smaller amounts of water are gained or lost through GHB cells in Layers 1 and 6.

The Layer 1 water balance indicates that 97.5 percent of groundwater recharge and 96.7 percent of evapotranspiration losses of groundwater occur either in the alluvial systems of the San Juan and La Plata Rivers and adjacent areas or at the Hogback (calculated as Layer 1 partial results for all other areas divided by model totals for recharge and evapotranspiration, respectively, multiplied by 100). Less than 0.1 percent of groundwater recharge occurs through Layers 2, 3, 4, and 5. About 1.4 percent of evapotranspiration occurs through Layers 2, 3, 4, and 5. Therefore, only about 2.5 percent of groundwater recharge and 3.2 percent of evapotranspiration losses occur in study area ephemeral channel areas and adjacent areas (note that ephemeral stream channel systems outside of the SJM lease area were not included in the model). In Layer 1, on a volumetric basis, slightly more recharge gains than evapotranspiration losses occur in ephemeral stream channel cells. The overall model-wide evapotranspiration point loss rate is $1.92 \times 10^{-4}$ $\mathrm{m} / \mathrm{d}\left(6.31 \times 10^{-4} \mathrm{ft} / \mathrm{d}\right.$, calculated as daily evapotranspiration model result divided by total model area) averaged across the study area. This value is at the low end of the potential evapotranspiration range (table 5).
The general water balance indicates that aquifer losses to streamflow are within 2.9 percent of aquifer gains from streamflow. The model indicates that groundwater fluxes upward from the Kls (Layer 5) into the Kpc are about five times greater than expected $\left(1,100 \mathrm{~m}^{3} / \mathrm{d}\right.$ simulated versus $170 \mathrm{~m}^{3} / \mathrm{d}$ estimated; $38.9 \times 10^{3} \mathrm{ft}^{3} / \mathrm{d}$ versus $6 \times 10^{3} \mathrm{ft}^{3} / \mathrm{d}$ ); however, groundwater exchanges between model layers are much more varied than the modeling results of Frenzel and Lyford (1982), upon which the conceptual estimate was based. In general, quantitative terms developed from conceptual modeling are similar to, or within an order of magnitude, of numerical modeling results (tables 5 and 7).

\section{Model Uncertainties and Limitations}

Numerical groundwater models by definition are simplified representations of the natural system under study. Simplifications, although required because of data gaps and other unknowns, introduce uncertainty into modeling results. The numerical model prepared for this project relied heavily on proxy data derived from Kernodle's (1996) previous groundwater modeling and resulting potentiometric mapping, incorporating unknown and unquantified uncertainties from those modeling results into this work. Model calibration was supported by a small number of predevelopment or earlydevelopment depth-to-water measurements. It is important to note, in the context of difficulties with model calibration, that potentiometric (water level) data were not collected in the SJM or vicinity until several years after industrial activities began in the area. Data gaps with respect to water levels and flux measurements limit the utility of model results.

Calibration results indicate a strong possibility that Kfn8 and Kpc potentiometric surfaces had already been impacted by regional oil and gas dewatering, based on the earliest available potentiometric data collected from wells SJ-13-2 and SJ-23-4. Confirmatory data to support this possibility have not been located at the time of writing. Steady-state calibration simulations retaining data from wells SJ-13-2 and SJ-23-4 tended to produce excessive regional evapotranspiration and insufficient regional groundwater recharge because adjustments to those regional stresses tended to reduce the OFVs modestly at these two groundwater monitoring locations, generating uncertainty in results of model calibration. For these reasons, these two data points were removed from the steady-state calibration but were retained for transient calibration.

Supportive data of stream seepage measurements were not found, no depth-to-groundwater measurements were found for the Kls and Kch (the single Kch data point found was outside the study area), and no reliable predevelopment groundwater measurements were found for the Kch, Kfn8, $\mathrm{Kkf}$, and Qal or Qal/Qnt in the vicinity of the SJM. These data gaps introduced difficulty in model construction and calibration and represent associated unquantified uncertainty in model results for this project. 
Layer 1 grid cell elevations were adjusted for reasonableness and to aid in model convergence. In general, the averaged surface elevations used for Layer 1 originated either with DEM data (USGS, 2017a), which was originally digitized from USGS quadrangle maps with vertical errors assumed to be one-half the contour interval of either 6 or $12 \mathrm{~m}$ (20 or $40 \mathrm{ft})$. Top and bottom elevations of Layers 2-6 originated by digitizing Kernodle's (1996) published Kpc surface, the scale of which is not stated and the associated error of which is unknown. Increases in cell thicknesses of Layers 4 and 5 to promote hydraulic connectedness of model layers in the vicinity of the simulated Hogback monocline may introduce potentiometric errors. Error mitigation was attempted by adjusting specific yield and porosity values of affected cells representing the Kpc; however, the effect of error mitigation is uncertain because of the lack of potentiometric data at and immediately downgradient from the Hogback.

A single mapped fault was incorporated into the numerical groundwater model. The locations of fractures in the Kpc, the Kfn8, the Kkf, or the Kls are unknown. Mercier (2010) notes that, aside from faults near the Hogback, faulting in the $\mathrm{Kf}$ has not been observed at SJM. The hydrologic effects of faults or fractures (whether or not faults and fractures enhance or retard groundwater flow) are unknown and uncertain.

For the most part, initial hydraulic conductivity values for all formations were obtained from published sources, which were also used to provide constraints for tested values (tables 3 and 6A). Storage parameter values and porosity values were obtained from published sources and were uncalibrated except for loose calibration of Layers 3 (Kfn8) and 4 (Kpc).

Mine dewatering schedules were estimated from information found in the San Juan Mine permit (MMD, 2017b) and from site-specific knowledge. The oil and gas well dewatering schedule was generalized from annual pumping data available for San Juan County oil and gas wells for the period between 2013 and 2015. Pre-1973 oil and gas pumping was not incorporated into the model because specific information for early constructed oil and gas well locations and pumping rates could not be found; this data gap produced uncertainty in the simulation of regional drawdown from oil and gas pumping because it is superimposed by mine dewatering in the vicinity of SJM. Furthermore, all oil and gas pumping was unrealistically assumed to halt instantaneously and at the same time as the cessation of mining, so as to identify potential groundwater CCB migration pathways in the absence of oil and gas pumping stresses outside of the SJM. Although this scenario is unlikely, the timeframe for cessation of oil and gas pumping in the San Juan Basin is not known.

CCB ash was assumed to be buried in interbedded layers with mine spoil such that the hydraulic properties of the mine spoil dominate the hydraulic response of the CCB ash and mine-spoil layers. Deviations from this assumption would likely change modeling results with respect to particle locations and times of arrival to hydrologic receptors.
Automated parameter estimation runs were performed in PEST (Doherty and Hunt, 2010) iteratively with one-at-atime manual calibration trials to visualize, assess, and quantify the effects of parameter-value changes to run results. Oneat-a-time calibration trials, required because of convergence problems, fail to capture interactions between two or more parameters (as only one parameter at a time is varied) and potentially precluded a thorough search for optimal parameter sets.

The MODPATH 5.0, which was used to identify groundwater-flow paths, considers only advective groundwater flow and ignores preferential flow features and longitudinally and laterally dispersive flow features of waterbearing formations, possibly yielding simplified flow paths and erroneous traveltimes with respect to calculation of the arrival time of particles to hydrologic receptors (Baca, 1999). Additionally, advective particle tracking does not account for transport characteristics of metals in the CCBs as they travel through variously reactive water-bearing zones (for example, sorption, desorption, leaching, and colloidal transport), which could affect the estimation of traveltimes. Flow paths are calculated from initial particle positions. The number of flow paths determined from this work was a maximum of 559. A reasonable attempt was made to emplace particles so as to identify all potential advective flow paths; however, it is not known if all potential flow paths are described in the model.

The MODFLOW-NWT version 1.0.9 did not have the capability of changing grid cells or parameter values in midrun. The number of transient one-year-time-step drawdown models was limited to two, the minimum needed to include groundwater-storage and grid-cell changes resulting from several decades of ongoing mining, mine-reclamation, and ash disposal. It is possible, though unknown, that the inclusion of additional, or more precise, temporal and spatial complexity and accuracy might produce different groundwater-flow paths.

\section{Groundwater Recovery: Transient Modeling and Particle Tracking Results}

The transient modeling approach is described in the section entitled "Modeling Approach." Postmining hydraulichead conditions were modeled under the assumptions that all local and regional dewatering will cease concurrently with the cessation of mining and that groundwater recharge and evapotranspiration will remain at calibrated values throughout the modeling period. The purposes of modeling were to (1) assess time to recovery of the premining steady state as determined by the steady-state model prepared for this project, and (2) identify groundwater-flow paths from CCB storage areas toward hydrologic receptors in the SJM vicinity.

Two scenarios (cases) of groundwater recovery and associated advective flow paths were simulated as described previously in the "Modeling Approach" section to assess variations in particle mobilization and transport attributable to the hydrologic properties of mine spoil, with a large fraction 
Table 7. Volumetric daily water balance results from calibrated steady-state model and layers, San Juan Mine groundwater model, showing correspondence to initial estimates from conceptual model.

[m³/d, cubic meter per day; S, storage; ET, evapotranspiration; GHB, general head boundary; Intralayer fluxes were generally not calculated for conceptual modeling]

\begin{tabular}{|c|c|c|c|c|c|c|c|}
\hline \multicolumn{4}{|c|}{ Numerical model results } & \multicolumn{4}{|c|}{ Conceptual model results (see table 5) } \\
\hline In: & $\left(\mathrm{m}^{3} / \mathrm{d}\right)$ & Out: & $\left(\mathrm{m}^{3} / \mathrm{d}\right)$ & In: & $\left(\mathrm{m}^{3} / \mathrm{d}\right)$ & Out: & $\left(\mathrm{m}^{3} / \mathrm{d}\right)$ \\
\hline Storage & 0.00 & Storage & 0.00 & Storage & 0 & Storage & 0 \\
\hline Recharge & $120,230.98$ & ET & $118,229.57$ & Recharge & 33,000 & Potential ET (range) & $\begin{array}{l}438,055- \\
2,628,328\end{array}$ \\
\hline GHB & $1,511.60$ & GHB & 649.55 & GHB & 232 & GHB & 4,200 \\
\hline Stream leakage & $96,149.94$ & Stream leakage & $99,011.99$ & Stream leakage & 334,350 & Stream leakage & 83,588 \\
\hline Total in & $217,892.51$ & Total out & $217,891.10$ & & & & \\
\hline In - out & & 1.4054 & & & & & \\
\hline Discrepancy (percent) & & 0.001 & & & & & \\
\hline \multicolumn{8}{|l|}{ Layer results ${ }^{1,2}$} \\
\hline Layer 1 in: & & Layer 1 out: & & & & & \\
\hline Bottom & 283.85 & Bottom & 155.24 & & & & \\
\hline Stream & $96,149.94$ & Stream & $99,011.99$ & Stream & 345,900 & Stream & 83,588 \\
\hline $\begin{array}{l}\text { Recharge } \\
\text { ephemeral stream cells } \\
\text { all other areas }\end{array}$ & $\begin{array}{r}\frac{119,622.38}{2,420.65} \\
117,201.73\end{array}$ & $\begin{array}{l}\text { ET } \\
\text { ephemeral stream cells } \\
\text { all other areas }\end{array}$ & $\begin{array}{r}116,653.24 \\
2,373.27 \\
114,279.97\end{array}$ & $\begin{array}{l}\text { Recharge } \\
\text { ephemeral stream channels } \\
\text { all except ephemeral streams }\end{array}$ & $\begin{array}{c}2,931 \\
30,000\end{array}$ & Potential ET (range) & $\begin{array}{l}438,055- \\
2,628,000\end{array}$ \\
\hline GHB & 0.00 & GHB & 234.29 & & & GHB & 3,915 \\
\hline Total in & $216,056.16$ & Total out & $216,054.76$ & & & & \\
\hline In - out & & 1.4053 & & & & & \\
\hline Discrepancy (percent) & & 0.001 & & & & & \\
\hline Layer 2 in: & & Layer 2 out: & & & & & \\
\hline Тор & 155.24 & Top & 283.85 & & & $\begin{array}{l}\text { Top (entry duplicated in } \\
\text { Layer 5) }\end{array}$ & 170 \\
\hline Bottom & 701.22 & Bottom & 96.00 & & & & \\
\hline Recharge & 77.46 & ET & 554.08 & & & & \\
\hline Total in & 933.92 & Total out & 933.92 & & & & \\
\hline In - out & & -0.0003 & & & & & \\
\hline Discrepancy (percent) & & -0.000 & & & & & \\
\hline
\end{tabular}


Table 7. Volumetric daily water balance results from calibrated steady-state model and layers, San Juan Mine groundwater model, showing correspondence to initial estimates from conceptual model.-Continued

$\left[\mathrm{m}^{3} / \mathrm{d}\right.$, cubic meter per day; S, storage; ET, evapotranspiration; GHB, general head boundary; Intralayer fluxes were generally not calculated for conceptual modeling]

\begin{tabular}{|c|c|c|c|c|c|c|c|c|c|}
\hline \multicolumn{5}{|c|}{ Numerical model results } & \multicolumn{5}{|c|}{ Conceptual model results (see table 5) } \\
\hline In: & $\left(m^{3} / d\right)$ & & Out: & $\left(\mathrm{m}^{3} / \mathrm{d}\right)$ & & In: & $\left(\mathrm{m}^{3} / \mathrm{d}\right)$ & Out: & $\left(m^{3} / d\right)$ \\
\hline Layer 3 in: & & Layer 3 out: & & & & & & & \\
\hline Top & 96.00 & Top & & 701.22 & & & & & \\
\hline Bottom & 618.21 & Bottom & & 13.62 & & & & & \\
\hline \multirow[t]{2}{*}{ Recharge } & 0.63 & ET & & 0.00 & & & & & \\
\hline & & $\begin{array}{l}\text { Underground } \\
\text { results fror }\end{array}$ & $\begin{array}{l}\text { dewatering (average } \\
\text { n transient modeling) }\end{array}$ & $\begin{array}{l}\quad 1,520 \\
\text { (average daily, } \\
\text { not considered } \\
\text { in steady-state } \\
\text { results) }\end{array}$ & & & & Underground dewatering & 453-608 \\
\hline Total in & 714.84 & Total out & & 714.84 & & & & & \\
\hline In - out & & & 0.0003 & & & & & & \\
\hline Discrepancy (percent) & & & 0.000 & & & & & & \\
\hline Layer 4 in: & & Layer 4 out: & & & & & & & \\
\hline Top & 13.62 & Top & & 618.21 & & & & & \\
\hline Bottom & $1,099.74$ & Bottom & & 3.45 & & & & & \\
\hline Recharge & 530.10 & ET & & $1,021.80$ & & & & & \\
\hline Total in & $1,643.46$ & Total out & & $1,643.46$ & & & & & \\
\hline In - out & & & 0.0000 & & & & & & \\
\hline Discrepancy (percent) & & & 0.00 & & & & & & \\
\hline Layer 5 in: & & Layer 5 out: & & & & & & & \\
\hline Тор & 3.45 & Top & & $1,099.74$ & & & & $\begin{array}{l}\text { Top (entry } \\
\quad \text { duplicated in Layer 2) }\end{array}$ & 170 \\
\hline Bottom & $1,096.33$ & Bottom & & 0.00 & & & & & \\
\hline Recharge & 0.40 & ET & & 0.45 & & & & & \\
\hline Total in & $1,100.19$ & Total out & & $1,100.19$ & & & & & \\
\hline In - out & & & -0.0000 & & & & & & \\
\hline Discrepancy (percent) & & & -0.000 & & & & & & \\
\hline Layer 6 in: & & Layer 6 out: & & & & & & & \\
\hline Тор & 0.00 & Тор & & $1,096.33$ & & & & & \\
\hline GHB & $1,511.60$ & GHB & & 415.26 & GHB & & 232 & GHB & 285 \\
\hline Total in & $1,511.60$ & Total out & & $1,511.60$ & & & & & \\
\hline In - out & & & -0.0000 & & & & & & \\
\hline Discrepancy (percent) & & & -0.000 & & & & & & \\
\hline
\end{tabular}

${ }^{1}$ Water budget layer results from Groundwater Vistas postprocessor, v.6.87 build 1 (Environmental Simulations Inc., 2014).

${ }^{2}$ Cumulative in and out totals vary between total model totals because the layer mass balances include fluxes between layers.

${ }^{3}$ Layer 1 totals for recharge and evapotranspiration categorize results at San Juan Mine vicinity ephemeral stream channels versus elsewhere. 
of swelling clay that is layered with CCB ash when it is buried. Case 1 applied the value for hydraulic conductivity of SJM mine spoil $\left(7.344 \times 10^{-3} \mathrm{~m} / \mathrm{d}\right.$; Thomson and others, 2012) and porosity (40 percent) reported by Metric Corporation (1990); this case was considered to be the more conservative between the two cases because it was based on published parameter values derived from SJM data. Case 2 used reduced values for those parameters in recognition that mine spoil contains a large fraction of swelling clay (Thomson and others, 2012), however, with potentially unknown hydrologic characteristics. Thomson and others (2012) reported their hydraulic conductivity estimates of mine spoil as a maximum value, for example (table 3). Case 2 assumptions incorporated an estimate for greatly reduced hydraulic conductivity $\left(8.64 \times 10^{-7} \mathrm{~m} / \mathrm{d}\right.$; the estimated value applied was one order of magnitude less than Luther and others' [2005] highest value reported for SJM spoil) and greatly reduced effective porosity (5 percent; Bear, 1972) as compared with reported values, recognizing that it is standard to determine porosity values from oven-dried samples. Reduced hydraulic conductivity is expected to greatly reduce advective flow of particles from CCB repositories; however, reduced porosity, as it is related inversely to particle velocity, is expected to increase advective traveltimes. All other calibrated parameters and stresses were held constant between the two cases.

\section{Groundwater Recovery to the Premining Steady State}

Based on results of Case 1 of the groundwater-recovery model, groundwater at CCB storage areas will recover to the former steady state or in some locations a new steady state at variable rates, depending on proximity to the residual coneof-groundwater depression located at the underground mine (shown on the first day of the first stress period after cessation of dewatering, fig. 31). The steady state is not recovered at CCB storage pits until between 6,600 and 10,600 years after the cessation of local and regional dewatering.

\section{Particle Tracking Results}

A total of 559 particles were digitized into parts of Layers 2 and 3 in grid cells representing CCB ash storage areas (fig. 31). For Case 1 conditions, 528 particles were activated (fig. 32), while 31 particles were never activated because their locations were not rewetted at the assigned particle-activation time. The motion of 235 particles stopped during the 20,000-year simulation as they arrived at the upper surface of the groundwater table in Layers 1 and 2, and 293 particles remained active throughout the simulation. Figure 32 displays all particle tracks generated throughout the 20,000-year tracking period.

The majority of particle tracks resulting from Case 1 (conservative) conditions (fig. 32) trend from CCB disposal areas toward western, southern, and southeastern directions, generally mixing between Layers 2 and 3 (shown in orange and yellow, respectively, fig. 32). Some particles, located in repositories near the southeastern corner of the former surface-mined area, migrate through Layer 2 to Layer 3 and then southward toward the San Juan River; the earliest arrival along this pathway is 2,400 years after the cessation of mining. Most of the particles migrate upward into Layer 1 (shown in green, fig. 32), Qal/Qnt of the Shumway or Westwater Arroyos. In the Case 1 simulation, particles first reach the ephemeral channel system after about 1,320 years. A large portion of particles eventually enter the upper Layer 1 grid cell representing the upper reach of the truncated SA (undermined) and some enter the SABR (fig. 1A). Many of the particles that enter the Qal/Qnt travel to the San Juan River alluvium; the earliest arrival to San Juan River alluvium along this pathway is year 1,520 after the cessation of mining (fig. 32). Particles from south CCB repositories enter the San Juan River alluvium 2,400 years after cessation of local and regional dewatering.

All 559 particles were activated in Case 2. Many fewer particles migrate outside of CCB repositories. This result is attributed to the greatly reduced hydraulic conductivity value for SJM mine spoil. The particles that do migrate travel with greater advective velocities through the reclaimed pits, reaching the Shumway Arroyo alluvium by year 760 after the cessation of mining and from there reaching the San Juan River alluvium by year 880 after the cessation of mining. Particles from south CCB repositories reach the San Juan River alluvium by year 2,200 after the cessation of mining. The faster traveltimes from the Case 2 scenario are attributed to reduced porosity of mine spoil.

Thomson and others (2012) found in their study of leachate that is likely to be generated by stored CCBs at SJM that the potential for groundwater contamination was small; however, their unsaturated-zone modeling did not account for the magnitude of upward-vertical gradients conceptualized to be present in the CCB ash storage areas. MODPATH results are based on the potential for advective travel in the saturated zone, and these results accordingly predict that particle motion will cease in unsaturated conditions.

Numerical modeling results of both Case 1 and Case 2 (fig. 32) indicate there is potential for metals leached from CCB ash to migrate to the Shumway/Westwater Arroyo alluvium and to the San Juan River alluvium. For simulating these two cases, the variation of arrival times and numbers of particles mobilized were produced (as described in the preceding paragraphs) by adjusting two hydraulic parameters of mine spoil: hydraulic conductivity and porosity. The variation of Case 1 and Case 2 results are directly related to the uncertainty in those two hydraulic parameter values. The large variability in these results indicates the model is highly sensitivity to these two parameter values. Because of time constraints, additional scenario analyses to assess sensitivities to other parameter values were not performed. However, several model versions were tested during the extended modeling period. Rejected model versions produced similar particle track locations, albeit with different traveltimes. 
A. Layer 3 at start of first stress period (day 1 ) of the groundwater recovery model

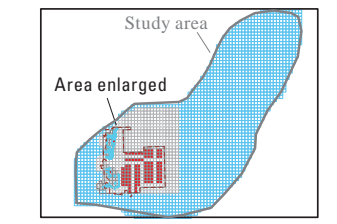

EXPLANATION

Mine permit boundary

Mine lease boundary

- 1,585 - Potentiometric contour-

Shows elevation at whic

water level would have

stood in tightly cased well

Contour interval 61 meters.

Datum is NAVD 88

Intale Initial particle position

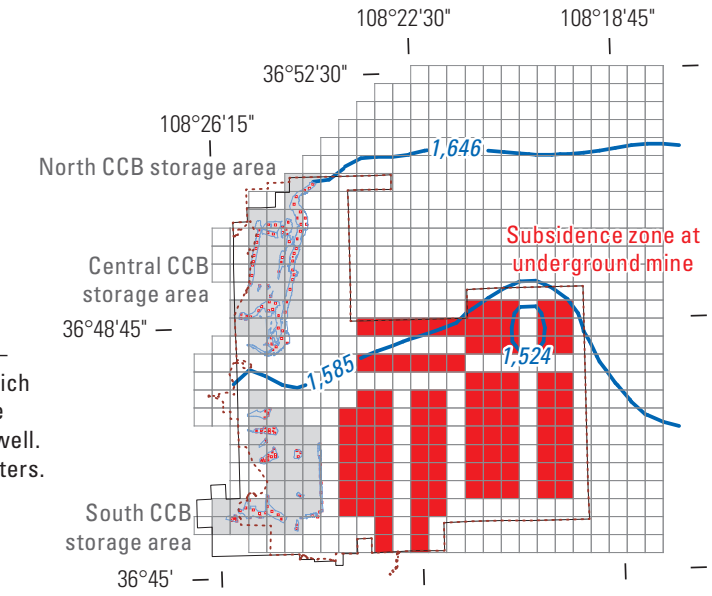

NAVD 88, North American Vertical Datum of 1988

CCB, Coal combustion byproduct

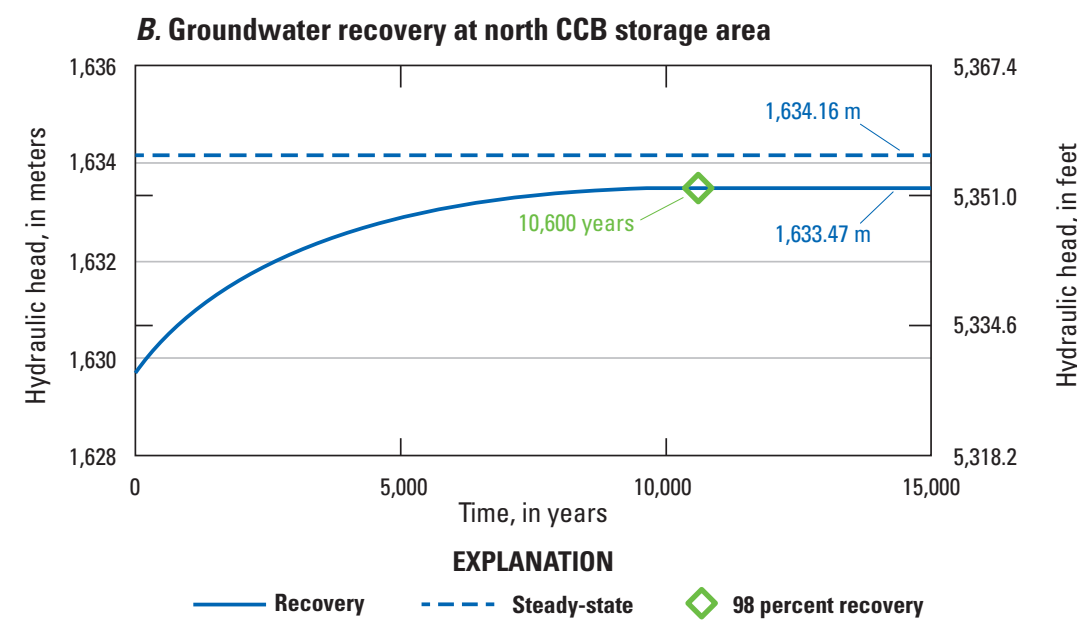

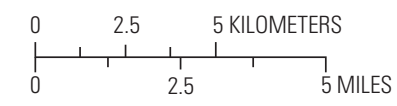

Figure 31. Modeled groundwater recovery timing at north, central, and south coal combustion byproduct (CCB) storage areas for Layer 3 with location map showing initial

particle positions, subsidence zone at underground mine, and potentiometric surface for Layer 3 at the start of the first stress period (day 1 ) of the groundwater-recovery model.
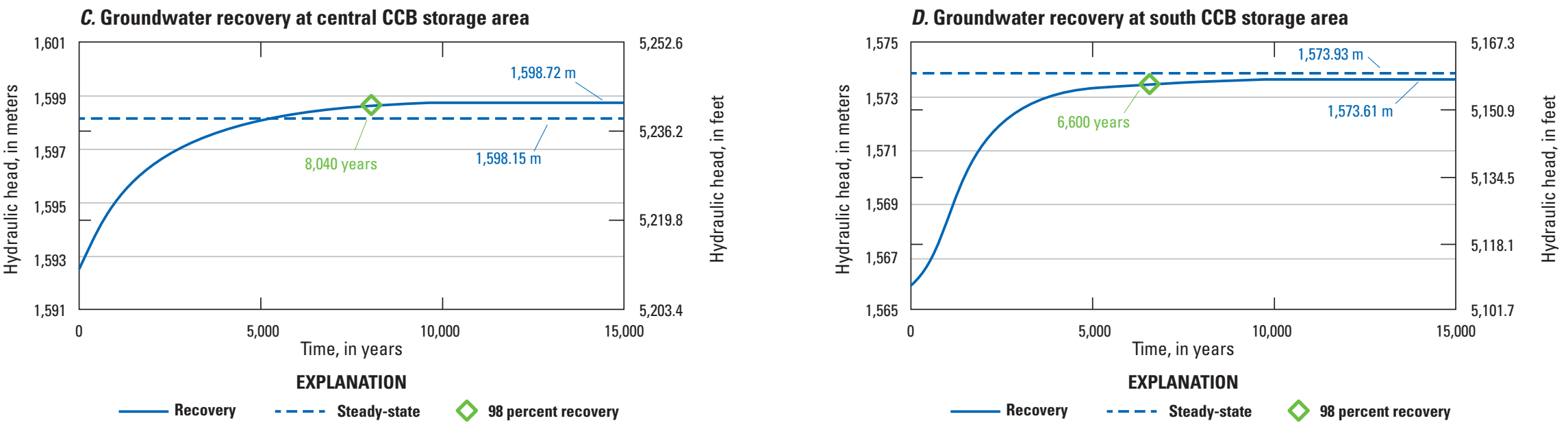
Case 1: Largest mine-spoil hydraulic conductivity and porosity values

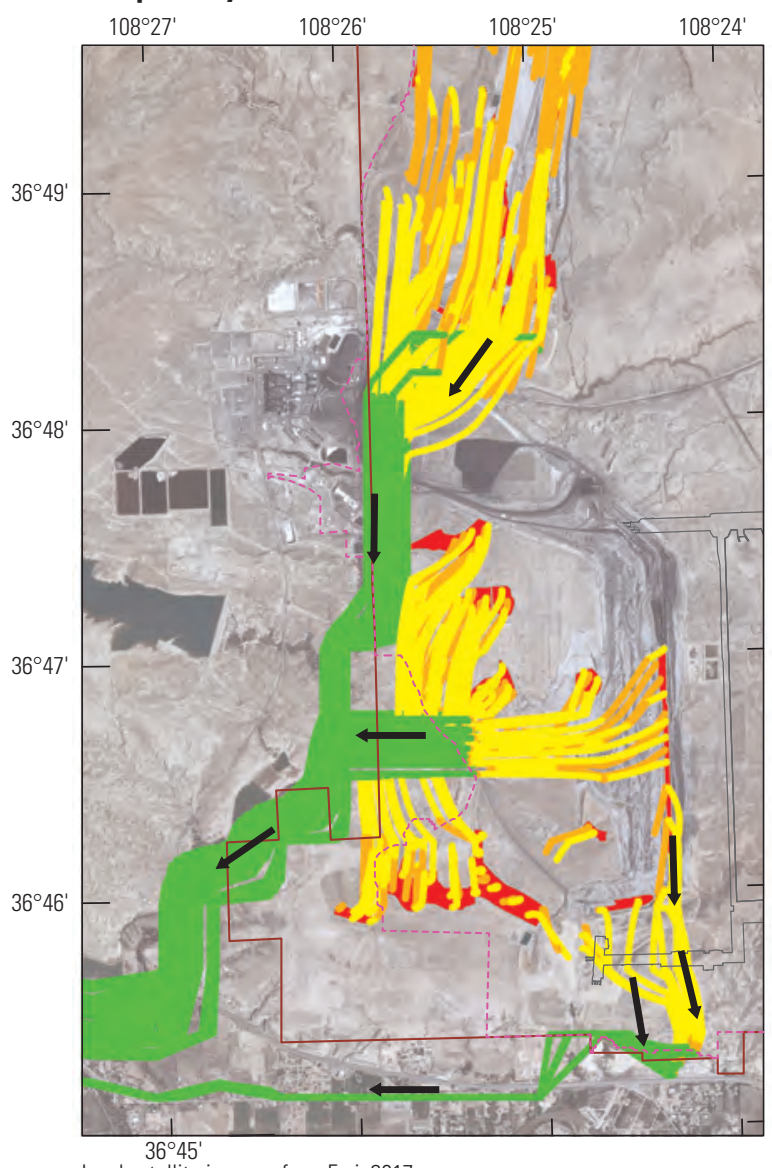

Land satellite imagery from Esri, 2017

Advective flow paths: Case 1 results for 20,000-year simulation. Particles reach Shumway Arroyo (SA) alluvium by 1,320 years after cessation of mining and from there reach the San Juan River (SJR) alluvium after about 1,520 years. Particles from south repositories reach SJR alluvium by vear 2,400 after mining ends.
Case 2: Reduced mine-spoil hydraulic conductivity and porosity values

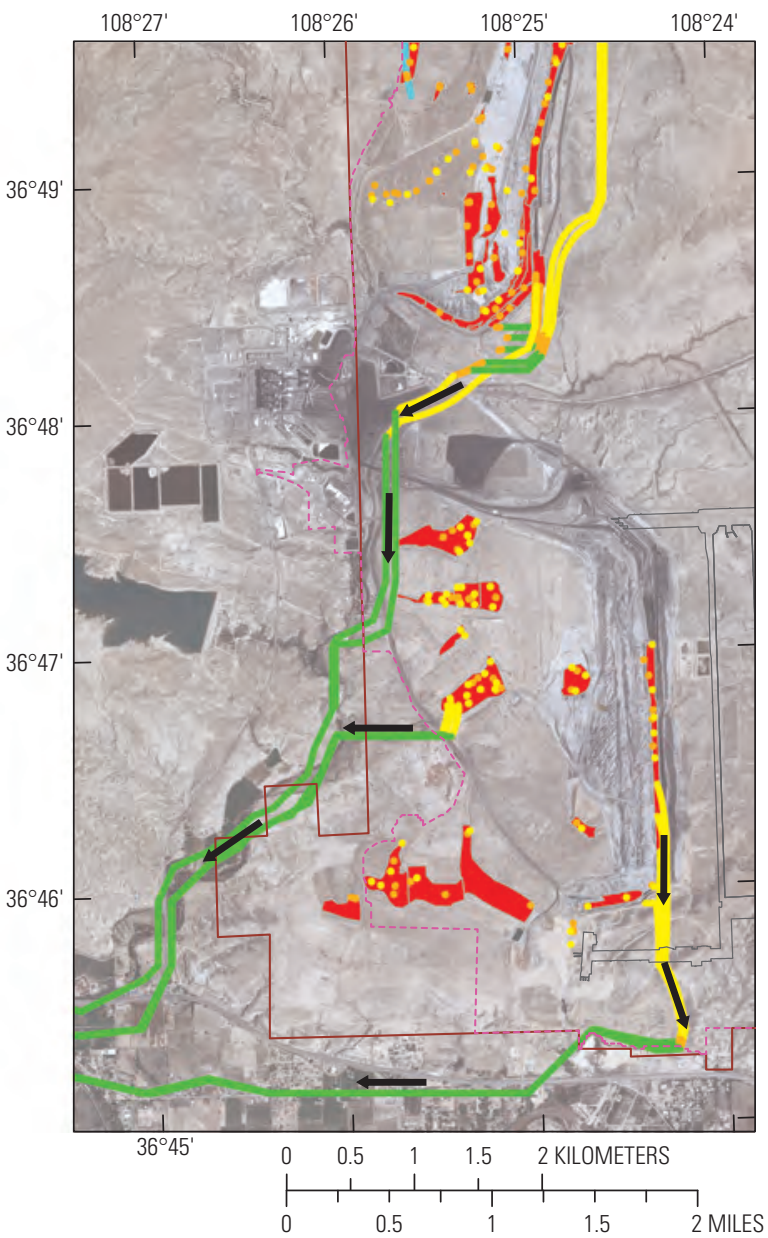

Advective flow paths: Case 2 results for 20,000-year simulation. Particles reach SA alluvium by 760 years after cessation of mining and from there reach the SJR alluvium after about 880 years. Particles from south repositories reach SJR alluvium by year 2,200 after mining ends.

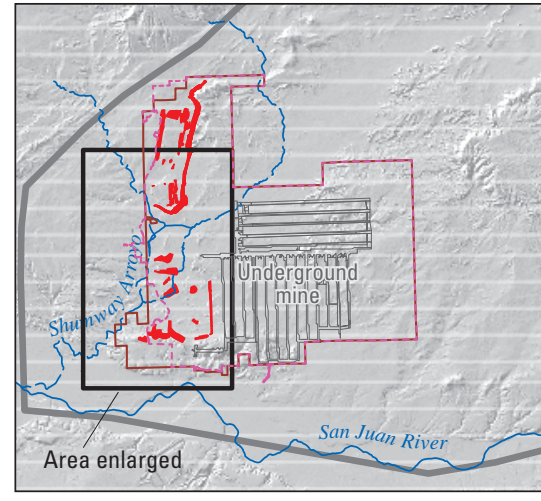

Locations of potential hydrologic receptors

\section{EXPLANATION}

Coal combustion byproducts (CCB) ash repositories (MMD, 2017b)

Underground mine workings (MMD, 2017b)

Modeled particle track, by layer

1 (Qal/0nt)

2 (Kkf, CCB ash repositories)

3 (Kfn8, subsidence zone)

4 (Kpc)

San Juan Coal Mine permit area boundary San Juan Coal Mine lease area boundary (MMD, 2017b)

\section{Study area boundary}

$\longleftarrow$ Groundwater flow direction

MMD, Mining and Minerals Division of New Mexico Energy Minerals and Natural Resources Department; Qal/Qnt, Quaternary alluvium and undifferentiated Naha and Tsegi eolian deposits; Kkf, Cretaceous Kirtland Shale and Fruitland Formation (undifferentiated); Kf, Cretaceous Fruitland Formation: Kfn8, Number 8 Coal Seam of the Kf: Kpc, Cretaceous Pictured Cliffs Sandstone; SA, Shumway Arroyo; SJR, San Juan River

Figure 32. Modeled particle tracks and arrival times after cessation of dewatering. Case 1 applied largest reported hydraulic conductivity and porosity values for CCB respository (mine spoil) fill; Case 2 applied reduced values for both parameters. 


\section{Suggestions for Further Data Collection}

Several data gaps were identified as this project proceeded. The following data collection and field studies would help to resolve those data gaps.

- Seepage investigations of the San Juan, La Plata, and Animas Rivers would address the lack of baseline data available for quantifying exchanges between surface and groundwater systems in and around the study area.

- Because it is the only Shumway Arroyo Qnt/Qal well upgradient from the mining area, resumption of depth-to-groundwater measurements and collection of groundwater samples for chemical analysis at well GC would enhance knowledge of the connectivity between the alluvial, shallow Fruitland Formation, and minereclamation groundwater systems.

- Additional wells completed in undisturbed, deep parts of the Kfn8, the Kpc, and the Kls or Kch could provide data for the calculation of regional vertical and horizontal hydraulic gradients to decrease uncertainty of modeling results.

- A Qal/Qnt well upgradient from Well-QNT in the Westwater Arroyo alluvium would allow Qal/Qnt groundwater to be sampled for baseline parameters of the WWA (upper), prior to groundwater entering areas disturbed by industrial activities.

- Identification and clarification of the source of high dissolved solids concentrations observed at the Shumway Arroyo backwater reach would be useful in interpreting hydraulic processes.

- Synthesis of basin-scale interdisciplinary hydrologic and petroleum studies, including basin-scale numerical modeling studies, could augment SJM model simulations by aiding identification of ongoing effects from hydrocarbon extraction activities to potentially potable groundwater supplies in the SJM area and throughout the San Juan Basin.

- Characterization of hydraulic properties of SJM mine-spoil layered with CCB ash would improve identification of potential migration pathways of associated metals.

- Scenario analyses with the numerical model could be used to assess potential implications of ongoing mining activities, changes to the mining plan, and changes to the plan for disposal of CCB ash.

\section{Summary}

Coal combustion byproducts (CCBs), which are composed of fly ash, bottom ash, and flue gas desulfurization material, are produced by operation of the coal-fired San Juan Generating Station (SJGS), located in San Juan County, New
Mexico. CCBs have been buried nearby in former surfacemine pits at the San Juan Mine (SJM), also referred to as the San Juan Coal Mine, since the SJGS power plant began operation in the early 1970s. Disposal of CCBs is overseen by the Mining and Minerals Division (MMD) of the State of New Mexico Energy, Minerals and Natural Resources Department (NMEMNRD).

This report, prepared by the U.S. Geological Survey (USGS) in cooperation with the Mining and Minerals Division of the New Mexico Energy, Minerals and Natural Resources Department, describes results of a hydrogeologic assessment, including numerical groundwater modeling, focused on identifying the timing of groundwater recovery to the predevelopment steady state and identifying potential pathways for groundwater transport of metals that may be leached from stored CCBs to reach hydrologic receptors after the cessation of operations at the SJGS and the SJM. The purpose of this report is to present results of the hydrogeologic assessment and numerical modeling results.

The study area abuts the western boundary of the central San Juan Basin in San Juan County, N. Mex., and extends 1.2 kilometers $(\mathrm{km})$ into La Plata County, Colorado. The study area encompasses a nonrectangular area of 606 square kilometers $\left(\mathrm{km}^{2}\right)$. The Hogback monocline bounds the study area to the west, highland areas bound the study area to the northwest and north, a groundwater divide bounds the study area to the east, and the San Juan River alluvial groundwater system bounds the study area to the south. Land-surface elevations range from 1,975 meters (m) in highland areas to $1,536 \mathrm{~m}$ at the San Juan River.

Land uses in the study area include irrigated farming; cattle and sheep ranching; wildlife habitat; and industrial, commercial, residential, and recreational activities. Industries within the study area include widespread oil and gas extraction, coal mining, and electrical power generation. Oil and gas were discovered in the San Juan Basin around 1910 and have continued to be developed. Oil and gas wells operated in the San Juan Basin are assumed to drawdown and decrease the confining pressure of groundwater. Water for domestic, agricultural, recreational, industrial, and commercial uses is obtained from the San Juan River. Water for irrigated agriculture is diverted from the San Juan or La Plata Rivers or from sources outside the study area.

The SJGS, a mine-mouth generating station with a capacity of 1,848 megawatts, was located adjacent to strippable parts of the coal outcrop in the Fruitland Formation in the early 1970s. The original mining plan indicated that about 555 metric tons of ash will be produced annually for every megawatt of power produced. The SJGS uses about 16,330 metric tons of coal per day.

The SJM began operation as a surface coal strip mine in 1973. Coal was mined at an average rate of about 4.2 million metric tons per year. Coal production was shifted to underground mining in October 2002. Between 1986 and 2002, supplementary coal was brought to the SJGS from the La Plata Mine, located in the northernmost part of the study area. 
The San Juan Basin is a synclinal basin located in northwestern New Mexico and southwestern Colorado, extending into Arizona and Utah. Along parts of the western, northern, and eastern basin margins, uplifted rock strata dip steeply inward toward low points of the basin, whereas along the southern basin margin, strata dip gently, yielding asymmetric basin structure. Surficially, the oldest rocks of the San Juan Basin crop out along the basin margins, rocks of decreasing age crop out concentrically, and successively younger rocks crop out toward the basin interior. The central basin is located in the interior of the San Juan Basin and is bounded along its western, northwestern, and northern margins by the Hogback monocline, which is crested by Late Cretaceous sandstone beds that display increased faulting with proximity to the monocline. The study area is located along the northwestern margin of the central basin, along one of several shorelines of the Late Cretaceousage Western Interior Seaway. The combination of basin subsidence with seaway regression yielded thick sequences of interbedded marine sandstones and shales with overlying continental coal beds and shales deposited after the final regression.

All natural surface drainage in the study area is towards the perennially flowing San Juan River. Average streamflow is about 4,902,000 cubic meters per day $\left(\mathrm{m}^{3} / \mathrm{d}\right)$ along the San Juan River. The La Plata River, formerly perennial, currently flows intermittently from north to south and joins the San Juan River near the southeastern corner of the study area. Average streamflow along the La Plata River varies between $27,000 \mathrm{~m}^{3} / \mathrm{d}$ and $64,600 \mathrm{~m}^{3} / \mathrm{d}$.

Tributaries to La Plata and San Juan Rivers are generally ephemeral, flowing only in response to precipitation events. The two main watersheds that traverse the SJM and SJGS are the ephemeral Westwater and Shumway Arroyo systems. The Westwater Arroyo is the major tributary to the Shumway Arroyo. Prior to the initiation of industrial and agricultural activities in the area, the Shumway Arroyo flowed ephemerally in response to precipitation events. Between 1981 and 1984, the Westwater and Shumway Arroyos were diverted from their natural courses to two constructed diversion channels that route flow through the northern parts of the SJM and SJGS. The two diversions join near the northern boundary between the SJGS and the SJM and merge with the natural Westwater Arroyo at the southern part of the SJGS, north of the former natural confluence.

Coal has been surface mined southeast of the WestwaterShumway natural confluence; mined areas have been reclaimed. The reclamation fill of the entire area includes mine spoil and CCB ash. An area located between the SJM lease boundary and the former confluence of the Westwater and Shumway Arroyos was not mined. In this area, the former Shumway Arroyo remains intact. This reach called "the Shumway Arroyo backwater reach" is no longer subject to regional ephemeral runoff because it is hydraulically disconnected from the Shumway Arroyo (upper).
The SJGS and SJM use constructed ponds for storage of raw water, stormwater, groundwater pumped from mining areas, and brines. Brine-evaporation ponds are in use at SJGS and are believed to have leaked in the past. Temporary raw water irrigation ponds have been constructed in various locations on the SJM lease area to support irrigation of reclaimed surface-mining pits.

Along the northwestern, northern, and eastern San Juan Basin margins, water-bearing rocks of increasing age crop out with increasing elevation and dip steeply toward the lowest part of the basin. In high-elevation locations, snowpack and associated snowmelt and recharge to groundwater-bearing strata are greatest, promoting confined groundwater conditions toward the basin interior, where confining pressures increase with depth, potentially yielding vertically upward hydraulic gradients and upward groundwater flow.

The oldest rock formation included in the study is the Cliff House Sandstone (Kch), which is successively overlain by the Lewis Shale (Kls), the Pictured Cliffs Sandstone (Kpc), the Fruitland Formation (Kf) with associated coal seams including the Number 8 coal seam (Kfn8), and the Kirtland Shale (Kks) (where undifferentiated, the Kf and Kks are termed the Kkf), all Late Cretaceous in age. In some parts of the study area, the Kkf is overlain by Cretaceous-Tertiary-age rocks including the (Tertiary-Cretaceous Animas Formation (TKa) and the Ojo Alamo Sandstone (TKoa). These rocks are overlain, where pesent, by the Tertiary Nacimiento Formation (Tn). In and along stream channels and in other low-lying areas in the vicinity of the SJM, Quaternary Naha and Tsegi eolian surficial deposits (Qnt) occur. Quaternary alluvium (Qal) is present along ephemeral, intermittent, and perennial stream channels and may be incised into preexisting Qnt deposits, where Qnt deposits are mapped.

In the study area, the Kch and Qal are recognized as important water-bearing units. However, the great depth to the Kch, except in recharge areas near the Hogback monocline, likely precludes exploration for its use as a water supply although some oil and gas wells have been completed in this unit in eastern parts of the study area. The Qal groundwater sources are limited to locations near perennial and intermittently flowing streams in the study area. In some places, Qal groundwater quality is poor, and Kpc and Kf water quality is inferior.

Reclaimed surface-mine pits are considered to be part of the hydrostratigraphic framework of the study area. Reclaimed surface-mine pits are filled mainly with mine spoil (pulverized waste rock that was overburden of the target coal seam) and CCB ash. At the SJM underground mine, rock that overlies the $\mathrm{Kfn} 8$ coal seam is subject to subsidence into the void left after the coal seam has been removed, extending to a maximum height of $47.25 \mathrm{~m}$.

The SJGS produces three types of CCBs: (1) fly ash, (2) bottom ash, and (3) flue gas desulfurization material. Column-leachate tests performed on SJM CCB ash yielded leachate concentrations of aluminum, boron, barium, calcium, selenium, silicon, and vanadium, which although low, 
were higher than in native groundwater, whereas arsenic concentrations exceeded the primary drinking-water standard for the U.S. Environmental Protection Agency, and barium and arsenic concentrations exceeded groundwater standards for New Mexico.

Study-area scale-potentiometric surfaces of the Kch, Kls, and Kpc remain generally unknown, with the exceptions of results of previous modeling studies and of one map of the Kf drawn using oil-well pressure data. The Kpc and Kfn8 regional groundwater-monitoring wells with periods of record sufficient to identify long-term trends (1980-2013) display potentiometric declines of as much as $90 \mathrm{~m}$, which is interpreted to be caused primarily by oil and gas well pumping and possibly mine dewatering and secondarily by reduced groundwater recharge caused by prolonged drought since 2000.

Water-level elevation data collected at one reclaimed area displayed a reversing hydraulic-head relation between the spoil and the Kpc during the study period. Regional Kfn8 and Kpc long-term hydrographs are interpreted to indicate declining hydraulic heads through their periods of record (about 1980 through present), attributed to oil and gas pumping, mine dewatering, and long-term regional drought.

The shallow-alluvial water-table system flows from topographically higher areas toward topographically lower areas. The most upgradient shallow-alluvial monitoring well, used to identify baseline water-chemistry indicators, is located at least $3 \mathrm{~m}$ potentiometrically downgradient from brineevaporation ponds that are known to have leaked in the past.

Short-term hydrographs from wells located in Kkf, Qal/ Qnt and spoil fill at the north-central and western margins of the SJM lease area are interpreted to indicate that groundwater in at least one centrally located reclaimed surface-mining pit has already begun to recover. Hydrograph interpretation also indicates that at many locations in the shallow-alluvial groundwater system, evapotranspiration and groundwater recharge stresses are similar in the vicinity of the SJM. The major source of groundwater recharge to reclaimed areas can be inferred to be alluvial groundwater of variously disturbed ephemeral stream channels, recharged by focused flows following precipitation events. Hydrologic data collected during this project also support the inference that groundwater in reclaimed areas is contributed from the underlying Kpc under the influence of upwardly vertical hydraulic gradients. During active mining, it is expected that upwardly vertical gradients likely change spatially and temporally in response to underground mine and oil and gas dewatering.

For modeling purposes, the central San Juan Basin is conceptualized to be hydrologically disconnected from surrounding water-bearing units of the San Juan Basin along the uplifted Hogback monocline, the crest of which is Kch. For this reason, the Kch was selected to bound the west and north sides and bottom of the model domain. To the south, the model is bounded by the San Juan River, which was assumed to be a regional groundwater discharge feature. To the east, the model was bounded along a groundwater ridge present in previous Kpc and Kkf steady-state modeling results.
The Kch potentiometric surface, from results of previous modeling, is conceptualized to be higher in elevation than potentiometric surfaces of overlying units, generating upward vertical head gradients expected to promote upward groundwater flow. The potential for CCB storage pits to be subject to groundwater exchange with deeper units and with adjacent Qal/Qnt was, in this manner, incorporated into the conceptual model, in accordance with results of the hydrologic assessment.

The USGS numerical modeling package MODFLOWNWT was selected for this study for its capability in handling drying and rewetting of thin unconfined cells. Groundwater Vistas (GWV) preprocessing and postprocessing software was used to produce input files and to visualize model inputs and outputs. The GWV MODPATH 5.0 was used to generate advective flow-particle tracks. Manual calibration trials were performed iteratively with automated calibration runs to assess model sensitivities with respect to parameter, stress package, and boundary condition adjustments.

The model was constructed using the meter as the fundamental spatial unit and day as the fundamental time unit. The model grid was composed of 67 rows, 72 columns, and 6 layers and was discretized into uniform grid cells $500 \mathrm{~m}$ on a side $\left(0.25 \mathrm{~km}^{2}\right.$ area). The model layers represent (from top to bottom) Qal and Qnt (as undifferentiated Qal, Layer 1); CCB repositories, Kkf, and where present, undifferentiated Kkf, TKoa, and TKa (Layer 2); Kfn8 and where present, CCB repositories and subsided overburden (Layer 3); Kpc (Layer 4); Kls (Layer 5); and Kch (Layer 6).

One steady-state and three transient models were constructed. The steady-state model was used to simulate predevelopment conditions, to calibrate hydraulic parameters and boundary conditions, and to provide initialization for transient modeling. The first and second transient-drawdown models were used to simulate mine dewatering and oil and gas well groundwater extraction using a total of sixty-two 1-year stress periods, following either the reclamation schedule or information found in the mine permit. The simulation of transient drawdown was separated to incorporate hydraulic parameter and grid geometry changes because of mining disturbances after the first 44 stress periods. The third transient model, referred to as the groundwater-recovery model, was used to simulate groundwater recovery using 500 40-year stress periods and incorporated similar changes to represent effects of underground mining after the 18 stress periods from the second transient model.

Model boundaries were selected to coincide as much as possible with natural hydrologic boundaries or to be sufficiently distant from the SJM to minimize boundary effects on numerical modeling results. The MODFLOWNWT general head boundaries, zero-flux boundaries, stream boundaries, and recharge and evapotranspiration boundaries were used; dewatering for surface and underground mining was represented using drain boundary conditions and oil and gas well dewatering was simulated using extraction-well boundary conditions. The oil and gas well dewatering schedule was generalized from annual pumping data available for San 
Juan County oil and gas wells for the period between 2013 and 2015; oil and gas pumping from earlier years was incorporated to the degree possible, because specific information was lacking for early constructed oil and gas well locations and pumping rates.

Model calibration was performed iteratively using automated parameter estimation methods with manual oneat-a-time parameter- and boundary-condition sensitivity trials with 14 observed early-mine-development (1970s and 1980s) or inferred head values. The calibrated steady-state model generates a sum of squared differences objective function value (OFV) of 33.2531 square meters. Residuals range between $0.02 \mathrm{~m}$ for a Kfn8 target and $3.28 \mathrm{~m}$ for a Kkf target.

Hydraulic-head configurations and cell-by-cell flow results from the 20,000-year groundwater-recovery model were used to identify advective flow paths and particle traveltimes to hydrologic receptors using 559 particles. The particles were digitized manually into areas representing ash disposal areas in Layers 2 and 3.

Based on results of the groundwater-recovery model, groundwater at CCB storage areas will recover to the former steady state or in some locations to a new steady state between 6,600 and 10,600 years after the cessation of dewatering. Particle tracking of the scenario using largest reported hydraulic parameter values indicates that 235 of 559 particles exit at the upper surface of the groundwater table in Layers 1 and 2; 293 particles remained active throughout the simulation. The majority of particle tracks trend from CCB disposal areas toward western, southern, and southeastern directions. Some particles, located in repositories near the southeastern corner of the former surface-mined area, migrate southward toward the San Juan River; the earliest arrival along this pathway is 2,400 years after the cessation of mining. Most of the particles migrate upward into the Qal/Qnt of the Shumway or Westwater Arroyos. Particles first reach the ephemeral channel system after about 1,320 years. Many of the particles that enter the Qal/Qnt travel to the San Juan River alluvium; the earliest arrival to San Juan River alluvium along this pathway is 1,520 years after the cessation of mining.

\section{References}

Anderson, M.P., and Woessner, W.W., 1992, Applied groundwater modeling - Simulation of flow and advective transport: San Diego, California, Academic Press, Inc., $381 \mathrm{p}$.

Arguez, Anthony, Durre, Imke, Applequist, Scott, Squires, M.F., Vose, R.S., Yin, Xungang, and Bilotta, R., 2010, NOAA's 1981-2010 U.S. climate normals for Farmington Four Corners Regional Airport N. Mex., U.S., Mesa Verde National Park, Colo., U.S., and Fruitland, N. Mex., U.S.: National Oceanic and Atmospheric Administration (NOAA) National Centers for Environmental Information, DOI:10.7289/V5PN93JP [December 5, 2016].
Ayers, W.B., Jr., Ambrose, W.A., and Yeh, J.S., 1994, Coalbed methane in the Fruitland Formation, San Juan Basin-Depositional and structural controls on occurrence and resources, in Ayers, W.B., Jr., and Kaiser, W.R., eds., Coalbed methane in the Upper Cretaceous Fruitland Formation, San Juan Basin, New Mexico and Colorado: New Mexico Bureau of Mines and Mineral Resources Bulletin 146, p. 13-40, accessed June 27, 2017, at https:// geoinfo.nmt.edu/publications/monographs/bulletins/146/.

Ayers, W.B., Jr., and Kaiser, W.R., eds., 1994, Coalbed methane in the Upper Cretaceous Fruitland Formation, San Juan Basin, New Mexico and Colorado: New Mexico Bureau of Mines and Mineral Resources Bulletin 146, 216 p.

Ayers, W.B., Jr., and Zellers, S.D., 1994, Coalbed methane in the Fruitland Formation, Navajo Lake area-Geologic controls on occurrence and producibility, in Ayers, W.B., Jr., and Kaiser, W.R., eds., Coalbed methane in the Upper Cretaceous Fruitland Formation, San Juan Basin, New Mexico and Colorado: New Mexico Bureau of Mines and Mineral Resources Bulletin 146, p. 63-85, accessed June 27, 2017, at https:/geoinfo.nmt.edu/publications/ monographs/bulletins/146/.

Baca, Ernesto, 1999, On the misuse of the simplest transport model: Ground Water, v. 37, no. 4, p. 483. doi:10.1111/j.1745-6584.1999.tb01128.x.

Baltz, E.H., 1967, Stratigraphy and regional tectonic implications of part of Upper Cretaceous and Tertiary rocks, east-central San Juan Basin, New Mexico: U.S. Geological Survey Professional Paper 552, 101 p. [Also available at https://pubs.er.usgs.gov/publication/pp552.]

Bauer, C.M., 1916, Stratigraphy of a part of the Chaco River Valley, in Contributions to the geology and paleontology of San Juan County, New Mexico: U.S. Geological Survey Professional Paper 98-P, p. 271-278. [Also available at https://pubs.er.usgs.gov/publication/pp98P.]

Beach, L.J., and Jentgen, R.W., 1978, Coal test drilling for the San Juan mine extension, San Juan County, New Mexico: U.S. Geological Survey Open-File Report 78-960, 87 p. [Also available at http://pubs.er.usgs.gov/publication/ ofr78960.]

Bear, Jacob, 1972, Dynamics of fluids in porous media: New York, Dover Publications, Inc., 800 p.

Berry, F.A.F., 1959, Hydrodynamics and geochemistry of the Jurassic and Cretaceous systems in the San Juan Basin, northwestern New Mexico and southwestern Colorado: Stanford University, Ph.D. dissertation, accessed August 7, 2014, at http://sul-derivatives.stanford.edu/derivative?CSNI D=00017400\&mediaType=application/pdf. 
Bredehoeft, J.D., Neuzil, C.E., and Milly, P.C., 1983, Regional flow in the Dakota aquifer-A study of the role of confining layers: U.S. Geological Survey Water-Supply Paper 2237, 45 p. [Also available at https://pubs.er.usgs.gov/publication/ wsp2237.]

Brown, Barnum, 1910, The Cretaceous Ojo Alamo beds of New Mexico with description of the new dinosaur genus Kritosaurus: American Museum of Natural History Bulletin, v. 28, article 24, p. 267-274.

Chen, Dong, Pan, Zhejun, Liu, Jishan, and Connell, L.D., 2012, Characteristic of anisotropic coal permeability and its impact on optimal design of multi-lateral well for coalbed methane production: Journal of Petroleum Science and Engineering, v. 88-89, p. 13-28.

Collier, A.J., 1919, Coal south of Mancos, Montezuma County, Colo., in Contributions to economic geology, 1918, part II, mineral fuels: U.S. Geological Survey Bulletin 691-K, p. 293-310.

Condon, S.M., 1999, Fracture studies on the Upper Cretaceous Pictured Cliffs Sandstone and Fruitland Formation, northern San Juan Basin, La Plata County, Colorado, in Natural Fracture Systems in the Southern Rockies: Four Corners Geological Society, p. 85-96.

Cox, Dave, Onsager, Paul, Thomson, Jim, Reinke, Rick, Gianinny, Gary, Vliss, Christie, Hughes, Jim, and Janowiak, Matthew, 2001, San Juan Basin ground water modeling study-Ground water - surface water interactions between Fruitland coalbed methane development and rivers, accessed June 28, 2017, at http:// cogccuat.state.co.us/Library/sanjuanbasin/3m_project/ SanJuanBasinModelingStudy.pdf.

Craigg, S.D., 2001, Geologic framework of the San Juan structural basin of New Mexico, Colorado, Arizona, and Utah, with emphasis on Triassic through Tertiary rocks: U.S. Geological Survey Professional Paper: 1420, 70 p. [Also available at http://pubs.er.usgs.gov/publication/ pp1420.]

Craigg, S.D., Dam, W.L., Kernodle, J.M., and Levings, G.W., 1989, Hydrogeology of the Dakota Sandstone in the San Juan structural basin, New Mexico, Colorado, Arizona, and Utah: U.S. Geological Survey Hydrologic Investigations Atlas HA-720-I, 2 sheets.

Craigg, S.D., Dam, W.L., Kernodle, J.M., Thorn, C.R., and Levings, G.W., 1990, Hydrogeology of the Point Lookout Sandstone in the San Juan structural basin, New Mexico, Colorado, Arizona, and Utah: U.S. Geological Survey Hydrologic Investigations Atlas HA-720-G, 2 sheets.
Dam, W.L., Kernodle, J.M., Levings, G.W., and Craigg, S.D., 1990a, Hydrogeology of the Morrison Formation in the San Juan structural basin, New Mexico, Colorado, Arizona, and Utah: U.S. Geological Survey Hydrologic Investigations Atlas HA-720-J, 2 sheets.

Dam, W.L., Kernodle, J.M., Thorn, C.R., Levings, G.W., and Craigg, S.D., 1990b, Hydrogeology of the Pictured Cliffs Sandstone in the San Juan structural basin, New Mexico, Colorado, Arizona, and Utah: U.S. Geological Survey Hydrologic Investigations Atlas HA-720-D, 2 sheets.

Dane, C.H., 1936, The La Ventana-Chacra Mesa coal field, part 3, in Sears, J.D., Hunt, C.B., and Dane, C.H., Geology and fuel resources of the southern part of the San Juan Basin, New Mexico: U.S. Geological Survey Bulletin 860-C, p. 81-161.

Doherty, J.E., and Hunt, R.J., 2010, Approaches to highly parameterized inversion-A guide to using PEST for groundwater-model calibration: U.S. Geological Survey Scientific Investigations Report 2010-5169, 59 p.

Dubiel, R.F., 2013, Geology, sequence stratigraphy, and oil and gas assessment of the Lewis Shale Total Petroleum System, San Juan Basin, New Mexico and Colorado, chap. 5 of U.S. Geological Survey San Juan Basin Assessment Team, Total petroleum systems and geologic assessment of undiscovered oil and gas resources in the San Juan Basin Province, exclusive of Paleozoic rocks, New Mexico and Colorado: U.S. Geological Survey Digital Data Series 69-F, p. 1-45.

Dugal, K.N., and Soni, J.P., 1996, Elements of water resources engineering: New Age International, 604 p.

Emmons, S.F., Cross, Whitman, and Eldridge, G.H., 1896, Geology of the Denver Basin in Colorado: U.S. Geological Survey Monograph 27, 556 p.

Environmental Simulations Inc. [ESI], 2014, Groundwater Vistas software version 6, accessed June 29, 2017, at http://www.groundwatermodels.com/.

Esri, 2004, Shapefile of States, counties, and cities of the United States distributed with ArcView 3.1 mapping software in 2004.

Fassett, J.E., 1973, The saga of the Ojo Alamo Sandstone; or the rock-stratigrapher and the paleontologist should be friends, in Fassett, J.E., ed., Cretaceous and Tertiary rocks of the Colorado Plateaus: Four Corners Geological Society Memoir Book, p. 123-130. 
Fassett, J.E., 1977, Geology of the Point Lookout, Cliff House and Pictured Cliffs Sandstones of the San Juan Basin, New Mexico and Colorado, in Fassett, J.F., and James, H.L., eds., Guidebook of San Juan Basin III, northwestern New Mexico: New Mexico Geological Society, Twenty-eighth Field Conference, September 15-17, 1977, p. 193-197, accessed June 2014 at https://nmgs.nmt.edu/publications/ guidebooks/downloads/28/28_p0193_p0197.pdf.

Fassett, J.E., 2000, Geology and coal resources of the Upper Cretaceous Fruitland Formation, San Juan Basin, New Mexico and Colorado, chapter Q, in Kirschbaum, M.A., Roberts, L.N.R., and Biewick, R.H., eds., Geologic assessment of coal in the Colorado Plateau-Arizona, Colorado, New Mexico, and Utah: U.S. Geological Survey Professional Paper 1625-B, p. Q1-Q132, two CD-ROMs. [Also available at http://pubs.usgs.gov/pp/p1625b/Reports/ Chapters/Chapter_Q.pdf.]

Fassett, J.E., and Hinds, J.S., 1971, Geology and fuel resources of the Fruitland Formation and Kirtland Shale of the San Juan Basin, New Mexico and Colorado: U.S. Geological Survey Professional Paper 676, 76 p. [Also available at http://pubs.er.usgs.gov/publication/pp676.]

Federal Coal Management Program, 1979, Final environmental statement: Bureau of Land Management, Section 4.8.1, accessed June 29, 2017, at https://books. google.com/books?id=KTx6WkQpTLsC\&pg=PP281\& $\mathrm{dq}=$ potential+ET+6+San+Juan+County+NM\&hl=en\&s $\mathrm{a}=$ X\&ved=0ahUKEwjDtcm2_YfYAhVS8mMKHVSrBsQ6AEIJzAA\#v=onepage\&q=potential\%20ET\%206\%20 San\%20Juan\%20County\%20NM\&f=false.

Fetter, C.W., 1994, Applied hydrogeology (3d ed.): Maxwell Macmillan International, $691 \mathrm{p}$.

Freeze, R.A., and Cherry, J.A., 1979, Groundwater: Englewood Cliffs, N.J., Prentice-Hall, 604 p.

Frenzel, P.F., and Lyford, F.P., 1982, Estimates of vertical hydraulic conductivity and regional ground-water flow rates in rocks of Jurassic and Cretaceous age, San Juan Basin, New Mexico and Colorado: U.S. Geological Survey Water-Resources Investigations Report 82-4015, 67 p. [Also available at https://pubs.er.usgs.gov/publication/ wri824015.]

Gardner, J.H., 1909, The coal field between Gallina and Raton Spring, New Mexico, in the San Juan coal region in Campbell, M.R., Geologist in Charge, Contributions to Economic Geology, 1907, part II: U.S. Geological Survey Bulletin 341, p. 335-351, 1 plate, accessed December 20, 2017, at https://pubs.usgs.gov/bul/0341/report.pdf.

GO-TECH, 2014, 2016, San Juan County, New Mexico well data, accessed May 21, 2014, July 31, 2014, October 12, 2016, at http://gotech.nmt.edu/gotech/Main.aspx.
Green, G.N., 1992, The digital geologic map of Colorado in ARC/INFO format: U.S. Geological Survey Open-File Report 92-0507, 9 p., accessed June 29, 2017, at http:// pubs.usgs.gov/of/1992/ofr-92-0507/.

Green, G.N., and Jones, G.E., 1997, The digital geologic map of New Mexico in ARC/INFO format: U.S. Geological Survey Open-File Report: 97-52, 9 p.

Hack, J.T., 1941, Dunes of the western Navajo Country: Geographical Review, v. 31, no. 2, p. 240-263, accessed May 30, 2013, at http://www.jstor.org/stable/210206.

Hammond Conservancy District, 2016, Crop water requirements, accessed June 29, 2017, at http:// hammondcon.org/cropwaterrequirements.html.

Hejl, H.R. Jr., 1982, Hydrologic investigations and datacollection network in strippable coal-resource areas in northwestern New Mexico: U.S. Geological Survey OpenFile Report 82-358, 36 p. [Also available at https://pubs. er.usgs.gov/publication/ofr82358.]

Holmes, W.H., 1877, Geological report on the San Juan district: Ninth Annual Report U.S. Geological and Geographical Survey Territories for the year 1875, p. $237-$ 276.

Hoppe, W.G., 1978, Animas Chacra gas well data sheet, in Oil and Gas Fields of the Four Corners area: AAPG Datapages, Inc., accessed June 29, 2017, at http://archives.datapages. com/data/fcgs/data/014a/014001/184_four-corners140184. htm and at http://archives.datapages.com/data/fcgs/ data/014a/014001/pdfs/184.pdf.

Irwin, J.H., 1966, Geology and availability of ground water on the Ute Mountain Indian Reservation, Colorado and New Mexico: U.S. Geological Survey Water-Supply Paper 1576G. [Also available at http://pubs.er.usgs.gov/publication/ wsp1576G.]

Johnson, A.I., 1967, Specific yield-Compilation of specific yields for various materials: U.S. Geological Survey WaterSupply Paper 1662-D. [Also available at https://pubs. er.usgs.gov/publication/wsp1662D.]

Johnson, R.L., Cherry, J.A., and Pankow, J.F., 1989, Diffusive contaminant transport in natural clay: A field example and implications for clay-lined waste disposal sites: Environmental Science and Technology, v. 23, no. 3, p. 340-349.

Kaiser, W.R., Swartz, T.E., and Hawkins, G.J., 1994, Hydrologic framework of the Fruitland Formation, San Juan Basin, in Ayers, W.B., Jr., and Kaiser, W.R., eds., Coalbed methane in the Upper Cretaceous Fruitland Formation, San Juan Basin, New Mexico and Colorado: New Mexico Bureau of Mines and Mineral Resources Bulletin 146, p. 133-163, accessed July 5, 2017, at https://geoinfo.nmt. edu/publications/monographs/bulletins/146/. 
Kaman Tempo, 1984, Final report cumulative hydrologic impact assessment-Effects of coal mining in the San Juan River Basin: Denver, Colo., prepared for Office of Surface Mining Western Technical Center.

Kelly, V.C., 1957, Tectonics of the San Juan Basin and surrounding areas, in Geology of the southwestern San Juan Basin: Four Corners Geological Society Second Field Conference, p. 44-52.

Kentucky Mining Institute, 2014, Kentucky Coal and Energy education project glossary of mining terms: Kentucky Coal Education, accessed October 2014 at http://www. coaleducation.org/glossary.htm.

Kernodle, J.M., 1996, Hydrogeology and steady-state simulation of ground-water flow in the San Juan Basin, New Mexico, Colorado, Arizona, and Utah: U.S. Geological Survey Water-Resources Investigations Report 95-4187, $117 \mathrm{p}$.

Kernodle, J.M., Levings, G.W., Craigg, S.D., and Dam, W.L., 1989, Hydrogeology of the Gallup Sandstone in the San Juan structural basin, New Mexico, Colorado, Arizona, and Utah: U.S Geological Survey Hydrologic Investigations Atlas HA-720-H, 2 plates.

Kernodle, J.M., and Philip, R.D., 1988, Using a geographic information system to develop a ground-water flow model, in McLean, J.S., and Johnson, A.I., eds., Regional aquifer systems of the United States, aquifers of the western mountain area: American Water Resources Association Monograph Series No. 14, p. 191-202.

Kernodle, J.M., Thorn, C.R., Levins, G.W., Craigg, S.D., and Dam, W.L., 1990, Hydrogeology of the Kirtland Shale and Fruitland Formation in the San Juan structural basin, New Mexico, Colorado, Arizona, and Utah: U.S. Geological Survey Hydrologic Investigations Atlas HA-720-C, 2 plates.

Keyes, C.R., 1906, Geological section of New Mexico: Science, New Series, v. 23, p. 921-922.

Klausing, R.L., and Welder, G.E., 1984, Availability of hydrologic data in San Juan County, New Mexico: U.S. Geological Survey Open-File Report 84-608, accessed October 2014 at http://pubs.usgs.gov/of/1984/0608/report. pdf.

Lakes, Arthur, 1889, Geology of Colorado coal deposits: Golden, Colorado, Colorado State School of Mines, Annual Report of Field Work and Analyses: Colorado State School of Mines.
Laubach, S.E., and Tremain, C.M., 1994, Tectonic setting of the San Juan Basin, in Ayers, W.B., Jr., and Kaiser, W.R., eds., Coalbed methane in the Upper Cretaceous Fruitland Formation, San Juan Basin, New Mexico and Colorado: New Mexico Bureau of Mines and Mineral Resources Bulletin 146, p. 9-11, accessed July 5, 2017, at http:// geoinfo.nmt.edu/publications/monographs/bulletins/146/.

Levings, G.W., Craigg, S.D., Dam, W.L., Kernodle, J.M., and Thorn, C.R.,1990a, Hydrogeology of the San Jose, Nacimiento, and Animas Formations in the San Juan structural basin, New Mexico, Colorado, Arizona, and Utah: U.S. Geological Survey Hydrologic Investigations Atlas HA-720-A, 2 plates.

Levings, G.W., Craigg, S.D., Dam, W.L., Kernodle, J.M., and Thorn, C.R., 1990b, Hydrogeology of the Menefee Formation in the San Juan structural basin, New Mexico, Colorado, Arizona, and Utah: U.S. Geological Survey Hydrologic Investigations Atlas HA-720-F, 2 plates.

Levings, G.W., Kernodle, J.M., and Thorn, C.R., 1996, Summary of the San Juan structural basin regional aquifersystem analysis, New Mexico, Colorado, Arizona, and Utah: U.S. Geological Survey Water-Resources Investigations Report 95-4188, 55 p.

Lewis, Rick, Ingraham, David, Pearcy, Marc, Williamson, Jon, Sawyer, Walt, and Frantz, Joe, 2004, New evaluation techniques for gas shale reservoirs: Schlumberger Reservoir Symposium, accessed October 6, 2017, at http:// citeseerx.ist.psu.edu/viewdoc/download?doi=10.1.1.455.24 $53 \&$ rep=rep1\&type=pdf.

Luther, J.G., Musslewhite, B., and Brown, C., 2005, The relationship between water quality and coal combustion by-product placement in an arid western coal mine, in Acid Drainage Technology Initiative Problem Summaries CCB-2 White Papers, accessed on September 13, 2011, and October 6, 2017, at http://www.worldofcoalash.org/2005/ ashpdf/213lut.pdf.

Lyford, F.P., 1979, Ground water in the San Juan Basin, New Mexico and Colorado: U.S. Geological Survey WaterResources Investigations Report 79-73, 22 p.

McDonald, M.G., and Harbaugh, A.W., 1988, A modular three-dimensional finite-difference ground-water flow model: U.S. Geological Survey Techniques of WaterResources Investigations, book 6, chap. A1, 586 p.

Mercier, J.M., 2010, Coal mining in the western San Juan Basin, San Juan County, New Mexico, in Fassett, J.E., Zeigler, K.E., and Lueth, V.W., eds., Geology of the Four Corners Country: New Mexico Geological Society 61st Fall Field Conference Guidebook, p. 173-180, accessed July 5, 2017, at https://nmgs.nmt.edu/publications/guidebooks/ downloads/61/61_p0173_p0180.pdf. 
Metric Corporation, 1982, Hydrologic conditions along the Westwater and Shumway drainages, San Juan County, New Mexico, v. 1, March 1982, accessed from New Mexico Environment Department Ground Water Bureau, New Mexico Environmental Improvement Division archives by contacting https://www.env.nm.gov/public-record-request/.

Metric Corporation, 1990, Hydrologic properties of the mine spoil at the San Juan Mine, San Juan County, New Mexico, accessible by contacting https://www.env.nm.gov/publicrecord-request/.

Metric Corporation, 2003, San Juan Generating Station groundwater resource investigation draft final report: Albuquerque, New Mexico, prepared for Public Service Company of New Mexico, accessed at New Mexico Environment Department Ground Water Bureau, accessible by contacting https://www.env.nm.gov/public-recordrequest/.

Metric Corporation, 2006, Preliminary investigation into the hydrologic characteristics of the Westwater and Shumway Arroyos in the vicinity of the San Juan Generating Station, San Juan County, New Mexico: New Mexico Environment Department Ground Water Bureau, accessible by contacting https://www.env.nm.gov/public-record-request/.

Metric Corporation, 2007, San Juan Generating Station groundwater resource investigation final report: Prepared for Public Service Company of New Mexico, filed at New Mexico Environment Department Ground Water Bureau, accessible by contacting https://www.env.nm.gov/publicrecord-request/.

Mining and Minerals Division [MMD] (New Mexico Energy, Minerals and Natural Resources Department [NMEMNRD]), 2014a, San Juan Mine information, accessed July 5, 2017, at http://wwwapps.emnrd.state. nm.us/MMD/CoalMinesQuery.

Mining and Minerals Division [MMD] (New Mexico Energy, Minerals and Natural Resources Department [NMEMNRD]), 2014b, La Plata Mine information, accessed July 5, 2017, at http://wwwapps.emnrd.state. nm.us/MMD/CoalMinesQuery.

Mining and Minerals Division [MMD] (New Mexico Energy, Minerals and Natural Resources Department [NMEMNRD]), 2014c, Black Diamond Mine information, accessed July 5, 2017, at http://wwwapps.emnrd.state. nm.us/MMD/CoalMinesQuery.

Mining and Minerals Division [MMD] (New Mexico Energy, Minerals and Natural Resources Department [NMEMNRD], 2017a, Western Coal Company information, accessed October 4, 2017, at http://wwwapps.emnrd.state.nm.us/ MMD/MMDWebInfo/MineDetail/Detail?MineId=13\&Ope ratorid $=1485$.
Mining and Minerals Division [MMD] (New Mexico Energy, Minerals and Natural Resources Department [NMEMNRD], 2017b, San Juan Mine Permit, San Juan Mine Permit, available upon request from Mining and Minerals Division of New Mexico Energy, Minerals and Natural Resources Department at http://www.emnrd.state. nm.us/MMD/.

Molenaar, C.M., 1977, Stratigraphy and depositional history of Upper Cretaceous rocks of the San Juan Basin area, New Mexico and Colorado, with a note on Economic resources, in New Mexico Geological Society Guidebook, 28th Field Conference, San Juan Basin III, p. 159-166.

Myers, R.G., and Villanueva, E.D., 1986, Geohydrology of the aquifers that may be affected by the surface mining of coal in the Fruitland Formation in the San Juan Basin, northwestern New Mexico: U.S. Geological Survey WaterResources Investigations Report 85-4251, 41 p. [Also available at http://pubs.usgs.gov/wri/1985/4251/report.pdf.]

National Geologic Map Database, 2014, Geolex search: U.S. Geological Survey and Association of American State Geologists database search webpage, accessed at various times during 2014 at https://ngmdb.usgs.gov/ Geolex/search.

Neuzil, C.E., 1994, How permeable are clays and shales? Water Resources Research, v. 30, no. 2, p. 145-150, accessed July 6, 2017, at http://riogrande.ees.nmt.edu/ outside/courses/hyd571/supplemental/Neuzil_93WR02930. pdf.

New Mexico Climate Center, 2014, Drought status data, accessed May 2014 at http://weather.nmsu.edu/.

New Mexico Office of the State Engineer [NMOSE], 2014a, New Mexico water rights reporting system, accessed August 2010 at http://nmwrrs.ose.state.nm.us/nmwrrs/ index.html.

New Mexico Office of the State Engineer [NMOSE], 2014b, Map of declared groundwater basins, accessed October 6, 2017, at http://www.ose.state.nm.us/RulesRegs/groundwater-regs/GroundWaterRegs-Article7.pdf.

New Mexico Office of the State Engineer [NMOSE], 2014c, Water-Rights Reporting System record SP03258, accessed at http://nmwrrs.ose.state.nm.us/nmwrrs/ReportProxy?que ryData=\%7B\%22report\%22\%3A\%22waterRightSummary \%22\%2C\%0A\%22WRFileDiv\%22\%3A\%22true\%22\%2C \%0A\%22WRFileBasin\%22\%3A\%22SP\%22\%2C\%0A\%22 WRFileNbr\%22\%3A\%2203258\%22\%2C\%0A\%22WRFile Suffix\%22\%3A\%22\%22\%2C\%0A\%22ownerDiv\%22\%3A \%22false $\% 22 \% 2 \mathrm{C} \% 0 \mathrm{~A} \% 22 \mathrm{BasinDiv} \% 22 \% 3 \mathrm{~A} \% 22$ false $\%$ 22\%7D. 
New Mexico Office of the State Engineer [NMOSE], 2014d, Water-Rights Reporting System record SP02838, accessed at http://nmwrrs.ose.state.nm.us/nmwrrs/ReportProxy?que ryData=\%7B\%22report\%22\%3A\%22 waterRightSummary \%22\%2C\%0A\%22WRFileDiv\%22\%3A\%22true\%22\%2C \%0A\%22WRFileBasin\%22\%3A\%22SP\%22\%2C\%0A\%22 WRFileNbr\%22\%3A\%2202838\%22\%2C\%0A\%22WRFile Suffix\%22\%3A\%22\%22\%2C\%0A\%22ownerDiv\%22\%3A \%22false\%22\%2C\%0A\%22BasinDiv\%22\%3A\%22false\% 22\%7D.

Nickelson, H.B., 1988, One hundred years of coal mining in the San Juan Basin, New Mexico: New Mexico Bureau of Mines and Mineral Resources Bulletin 111.

Niemczyk, T.M., and Walters, E.A., 1980, Assessment of water supply contamination due to underground coal gasification: New Mexico Water Resources Research Institute Report 128, accessed July 6, 2017, at https:// nmwrri.nmsu.edu/tr128/.

Niswonger, R.G., Panday, Sorab, and Ibaraki, Motomu, 2011, MODFLOW-NWT, A Newton formulation for MODFLOW-2005: U.S. Geological Survey Techniques and Methods 6-A37, 44 p.

Norwest Corporation, 2012, Data delivery of various draft lithological and well completion logs for wells constructed at San Juan Mine during 2011, accessed November 27, 2017, at https://webapps.usgs.gov/GeoLogLocator/\#!/ search.

Oldaker, P.R., 1991, Hydrogeology of the Fruitland Formation, San Juan Basin, Colorado and New Mexico, in Schwochow, S.D., Murray, D.K., and Fahy, M.F., eds., Coalbed methane of western North American: Rocky Mountain Association of Geologists, p. 61-66.

Otten, M., 1977, Irrigation ditches in the county: San Juan County Water and Sewer Study Section 3, accessed January 2011 at http://www.ose.state.nm.us/Pub/Library.php.

Parker, C.H., 2011, Analysis of coal combustion by-product disposal practices in arid climates-Leachate water quality: Albuquerque, New Mexico, University of New Mexico, Civil Engineering Department, M.Sc. thesis.

Parker, J.M., Riggs, E.A., and Fisher, W.L., 1977, Oil and gas potential of the San Juan Basin, in Fassett, J.E., James, H.L., and Hodgson, H.E., eds., New Mexico Geological Survey Twenty-Eighth Field Conference, September 14-17, 1977, p. 247-241.

Phillips, F.M., 1982, A geochemical investigation into the origins of ground-water salinity at Shumway and Westwater arroyos, San Juan County, New Mexico: New Mexico Environment Department preliminary draft report, archived material accessed June 10, 2013, accessible from New Mexico Environment Department by contacting https:// www.env.nm.gov/public-record-request/.
Pollock, D.W., 1994, User's Guide for MODPATH/ MODPATH-PLOT, version 3; A particle tracking postprocessing package for MODFLOW, the U.S. Geological Survey finite-difference ground-water flow model: U.S. Geological Survey Open-File Report 94-464, 248 p.

Public Service Company of New Mexico, 2014, Systems, accessed July 6, 2107, at http://www.pnm.com/systems.

Raymondi, R., Dye, A., Conrad, R., and Souder, K., 1983, Hydrologic conditions near Shumway and Westwater arroyos (power plant discharge to Dunlap farm): Typed memo, dated April 21, 1983, accessible from New Mexico Environmental Improvement Division archives held at New Mexico Environment Department by contacting https:// www.env.nm.gov/public-record-request/.

Reneau, W.E., Jr., and Harris, J.D., 1957, Reservoir characteristics of Cretaceous sands of the San Juan Basin, in Little, C.J., and Gill, J.J., eds., Guidebook to geology of southwestern San Juan Basin: Four Corners Geological Society, Second Field Conference, p. 40-43.

Riese, W.C., Pelzmann, W.L., and Snyder, G.T., 2005, New insights on the hydrocarbon system of the Fruitland Formation coal beds, northern San Juan Basin, Colorado and New Mexico, USA, in Warwick, P.D., ed., Coal systems analysis: Geological Society of America, Special Paper 387.

Roybal, F.E., and others, 1983, Hydrology of area 60, Northern Great Plains, and Rocky Mountain coal provinces, New Mexico, Colorado, Utah, and Arizona: U.S. Geological Survey Open-File Report 83-203, 140 p.

Saavedra, Paul, 1987, Surface water irrigation organizations in New Mexico: Santa Fe, New Mexico, New Mexico State Engineer Office Technical Division Report TDDC-87-2, accessed July 6, 2017, at http://www. nmacequiacommission.state.nm.us/Publications/oseacequia-rpt1987.pdf.

San Juan Water Commission, 2003, Region 2 - San Juan Basin Regional Water Plan, accessed July 2016 at http://sjwc.org/.

Schlumberger, 2017, Oilfield Glossary, Darcy definition, accessed on October 6, 2017, at http://www.glossary. oilfield.slb.com/Terms/d/darcy.aspx.

S.S. Papadopulos and Associates, Inc., 2006, Coalbed methane stream depletion assessment study - Northern San Juan Basin, Colorado; Boulder, Colorado: S.S. Papadopulos and Associates, Inc. in conjunction with Colorado Geological Survey, accessed October 5, 2017, at https://cogcc.state. co.us/documents/library/AreaReports/SanJuanBasin/ CMSDA_Study.pdf.

Stewart, A.M., 2017, Chemical analyses for arsenic, calcium, chloride, sodium, sulfate, sulfide and dissolved solids, August 2011 through December 2013, from groundwater sampled at or in the vicinity of the San Juan Coal Mine, New Mexico: U.S. Geological Survey data release, https:// doi.org/10.5066/F7Q81BJK. 
Stewart, A.M., 2018, MODFLOW-NWT and MODPATH5 models used to identify potential flow paths from San Juan Mine to hydrologic receptors, San Juan County, New Mexico: U.S. Geological Survey data release, https://doi. org/10.5066/F75719JV.

Stewart, A.M., and Thomas, Nicole, 2015, Hydrologic data from wells at or in the vicinity of the San Juan coal mine, San Juan County, New Mexico: U.S. Geological Survey Data Series 933, accessed July 10, 2017, at https://pubs. er.usgs.gov/publication/ds933.

Stone, W.J., 1987, Phase-III recharge study at the Navajo mine-Impact of mining on recharge: New Mexico Bureau of Mines and Mineral Resources Open-File Report 282, accessed July 10, 2017, at https://geoinfo.nmt.edu/ publications/openfile/downloads/200-299/282/ofr_282.pdf.

Stone, W.J., Lyford, F.P., Frenzel, P.F., Mizell, N.H., and Padgett, E.T., 1983, Hydrogeology and water resources of San Juan Basin, New Mexico: New Mexico Bureau of Mines and Mineral Resources, Hydrologic Report 6, 70 p.

Strobell, J.D., Hayes, P.T., and O’Sullivan, R.B., 1980, Preliminary geologic map of the Waterflow quadrangle, San Juan County, New Mexico: U.S. Geological Survey Miscellaneous Field Studies Map MF-1253, 1 plate. [Also available at http://pubs.er.usgs.gov/publication/mf1253.]

Taylor, D.J., and Huffman, A.C., Jr., 1998, Map showing inferred and mapped basement faults, San Juan Basin and vicinity, New Mexico and Colorado: U.S. Geological Survey Geologic Investigations Series I-2641, scale 1:500,000.

Taylor, J.R., 1997, An introduction to error analysis-The study of uncertainties in physical measurements, University Science Books, 327 p.

Thomson, B., Stormont, J., Stone, M., Webb, R., Parker, C., and Bramlett, K., 2012, Analysis of coal combustion by-products disposal practices at the San Juan MineHydrologic and water quality issues, final report: Albuquerque, New Mexico, University of New Mexico, Department of Civil Engineering, 173 p.

Thorn, C.R., Levings, G.W., Craigg, S.D., Dam, W.L., and Kernodle, J.M., 1990a, Hydrogeology of the Ojo Alamo Sandstone in the San Juan structural basin, New Mexico, Colorado, Arizona, and Utah: U.S. Geological Survey Hydrologic Investigations Atlas HA-720-B, 2 sheets.

Thorn, C.R., Levings, G.W., Craigg, S.D., Dam, W.L., and Kernodle, J.M., 1990b, Hydrogeology of the Cliff House Sandstone in the San Juan structural basin, New Mexico, Colorado, Arizona, and Utah: U.S. Geological Survey Hydrologic Investigations Atlas HA-720-E, 2 sheets.
U.S. Census Bureau, 2010 Population finder, accessed May 14, 2014, at http://www.census.gov/popfinder/.

U.S. Energy Information Administration, 2011, Review of emerging resources-U.S. shale gas and shale oil plays: Washington, D.C., U.S. Department of Energy, accessed July 10, 2017, at http://www.eia.gov/analysis/studies/ usshalegas/pdf/usshaleplays.pdf.

U.S. Environmental Protection Agency [EPA], 2004, The San Juan Basin, attachment 1, in Evaluation of impacts to underground sources of drinking water by hydraulic fracturing of coalbed methane reservoirs: Environmental Protection Agency 816-R-04-003, accessed October 4, 2017, at https://fracfocus.org/sites/default/files/publications/ evaluation_of_impacts_to_underground_sources_of_ drinking_water_by_hydraulic_fracturing_of_coalbed_ methane_reservoirs.pdf.

U.S. Environment Protection Agency [EPA], 2011, U.S. Environmental Protection Agency Region 6 Superfund Division Document 9119406, March 11, 2011, Freedom of Information Act No. 06-FOI-00561-10.

U.S. Environmental Protection Agency [EPA], 2014, Superfund Site Information PNM-San Juan Generating Station, accessed July 10, 2017, at http://cumulis.epa. gov/supercpad/cursites/csitinfo.cfm?id=0600942 and https://cumulis.epa.gov/supercpad/cursites/csitinfo. cfm?id=0600839.

U.S. Geological Survey [USGS], 1963, Waterflow, New Mexico, 7.5 minute quadrangle map, accessed September 19, 2014, at https://ngmdb.usgs.gov/topoview/ viewer/\#12/36.8123/-108.4383.

U.S. Geological Survey [USGS], 1995, Waterflow, New Mexico, 7.5 minute quadrangle map, accessed 2010 from New Mexico Water Science Center digital seamless-map archive.

U.S. Geological Survey [USGS], 2012-14, USGS water data for the Nation: U.S. Geological Survey National Water Information System database, accessed on multiple dates during 2012, 2013, and 2014 at https://doi.org/10.5066/ F7P55KJN.

U.S. Geological Survey [USGS], 2015, Online guide to MODFLOW, accessed July 10, 2017, at http://water.usgs. gov/ogw/modflow-nwt/MODFLOW-NWT-Guide/index. html.

U.S. Geological Survey [USGS], 2017a, National Map Digital Elevation Model data, accessed 2011 and 2014 at https:// nationalmap.gov/elevation.html.

U.S. Geological Survey, 2017b, Well log archive, accessed November 27, 2017, at https://webapps.usgs.gov/ GeoLogLocator/\#!/. 
U.S. Geological Survey National Water Information System [USGS NWIS], 2012-14, accessed on multiple dates during 2012, 2013, and 2014 at https://nm.water.usgs.gov/ infodata/.

U.S. Securities and Exchange Commission, 2011, San Juan Underground Mine Fire Incident, accessed June 2016 at http://www.sec.gov/Archives/edgar/containers/ fix030/81023/000119312511265363/d239237d8k.htm.

U.S. Southwest Energy Federal Task Force [SW Energy], 1972, Southwest energy study, an evaluation of coal-fired electric power generation in the Southwest: EPA Region 9 Library (ERAM) holdings, Call Number 'TD195.E4 S65 Report; App. A,C,E,F,J,L; Review’, accessed at https:// cfpub.epa.gov/ols/catalog/advanced_full_record.cfm?\& FIELD1=SUBJECT\&INPUT1=Electric\%20power\%20 production\%20Southwest\%20New\&TYPE1=EXACT\& LOGIC1=AND\&COLL=\&SORT_TYPE=MTIC\&item_ count $=2$.

Western Regional Climate Center, 2016, Monthly average pan evaporation, accessed July 10, 2017, at http://www.wrcc.dri. edu/htmlfiles/westevap.final.html\#NEW MEXICO.

Westmoreland Coal Company, 2016, Westmoreland completes acquisition and financing for San Juan Mine; Announces investor call for February 4, 2016: News release, accessed July 10, 2017, at http://westmoreland.com/2016/02/ westmoreland-completes-acquisition-and-financing-for-sanjuan-mine-announces-investor-call-for-february-4-2016/.
White, W.E., and Kues, G.E., 1992, Inventory of springs in the State of New Mexico: U.S. Geological Survey OpenFile Report 92-118, 253 p. [Also available at https://pubs. er.usgs.gov/publication/ofr92118.]

Williams, D., 1981, Correspondence to T. Hobbs, Mining and Minerals Division, New Mexico Environmental Improvement Division archived material accessed June 10, 2013, at New Mexico Environment Department, 2013, accessible by contacting https://www.env.nm.gov/publicrecord-request/.

Woodward, L.A., and Callendar, J.C., 1977, Tectonic framework of the San Juan Basin, 1977, in Fassett, J.E., and James, H.L., eds., Guidebook of San Juan Basin III, northwestern New Mexico: New Mexico Geological Society, Twenty-eighth Field Conference, September 15-17, 1977.

Wright, A.F., 1979, Bibliography of geology and hydrology, San Juan Basin, New Mexico, Colorado, Arizona, and Utah: U.S. Geological Survey Bulletin 1481, 123 p. [Also available at https://pubs.er.usgs.gov/publication/ b1481.]

For more information about this publication, contact

New Mexico Water Science Center

For additional information visit

https://nm.water.usgs.gov/

Publishing support provided by

Lafayette Publishing Service Center 


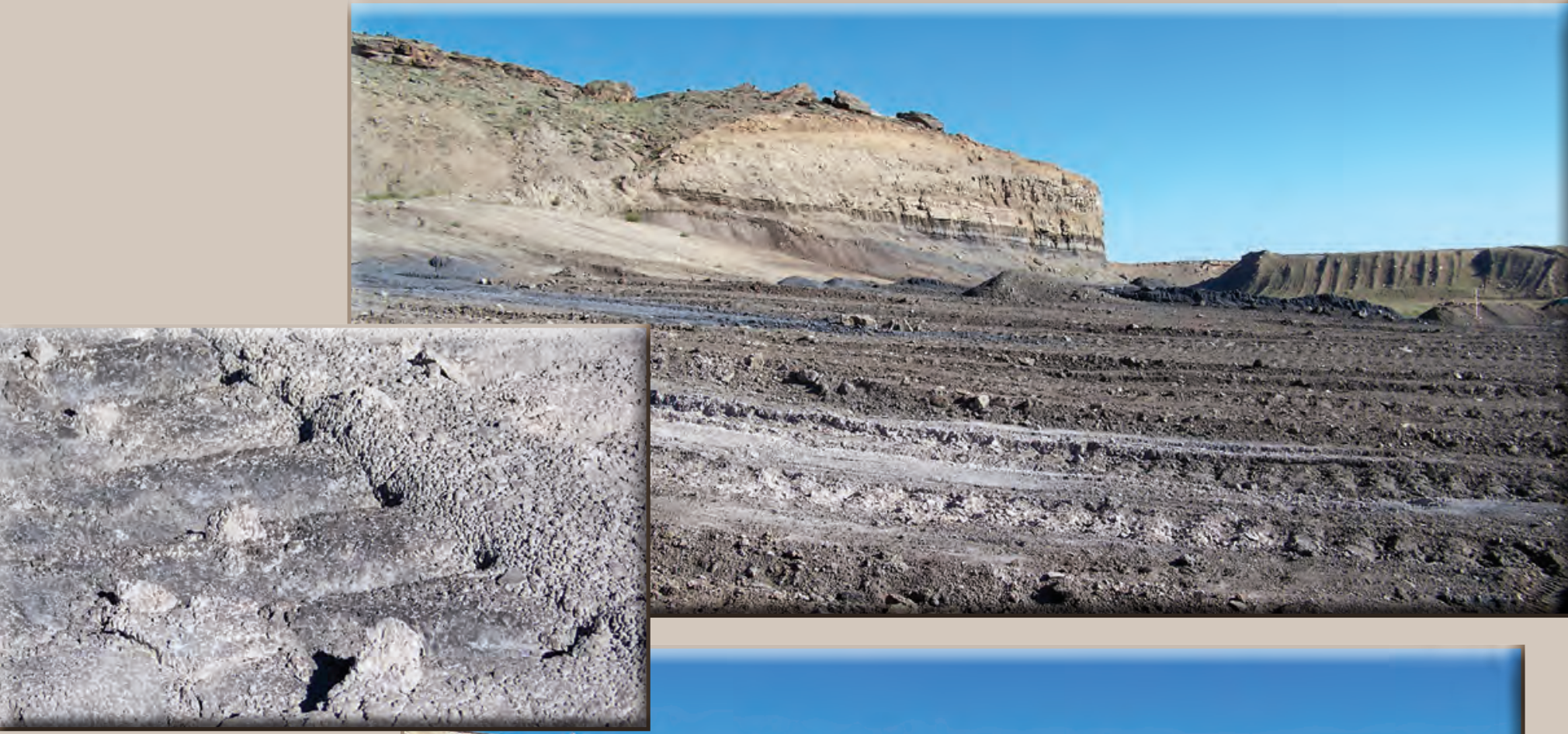

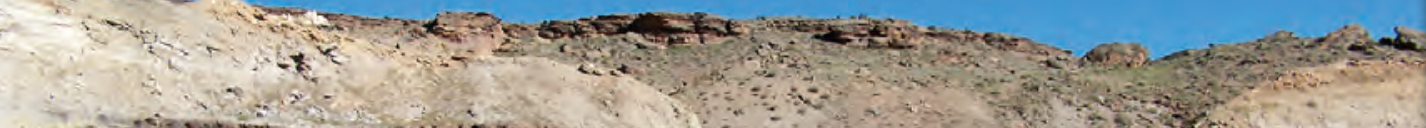

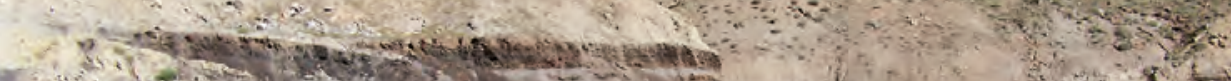

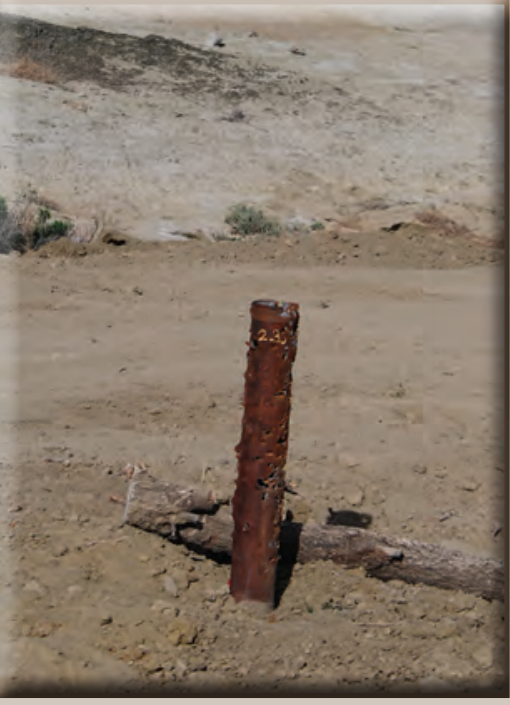

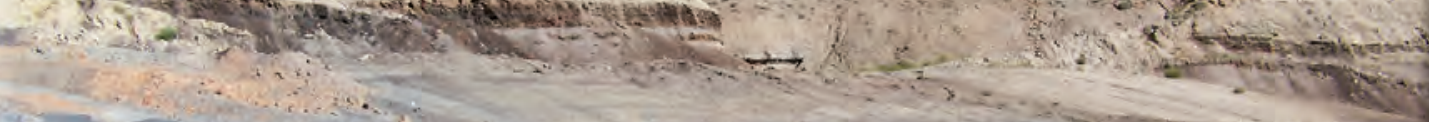
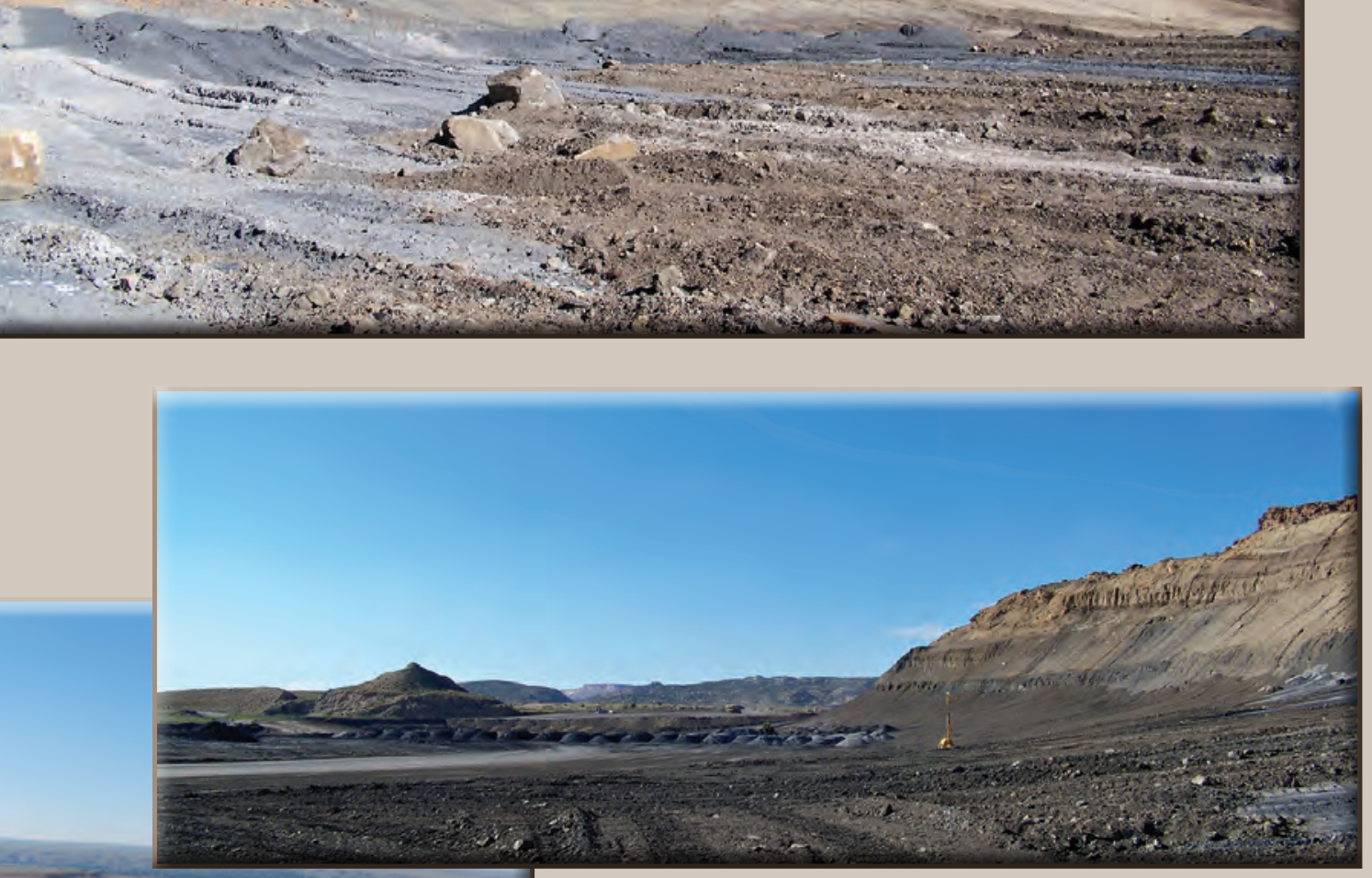